(2) norden 



\section{Forbedring af læse-, skrive- og IT-færdigheder for kort- uddannede voksne}

En nordisk forundersøgelse

Anna Steenberg Gellert et al

Center for Lœseforskning ved Københavns Universitet

TemaNord 2007:549 
Forbedring af læse-, skrive- og IT-færdigheder for kortuddannede voksne

En nordisk forundersøgelse

TemaNord 2007:549

(C) Nordisk Ministerråd, København 2007

ISBN 978-92-893-1528-9

Tryk: Ekspressen Tryk \& Kopicenter

Oplag: Fås kun som print-on-demand

Trykt på miljøvenligt papir som opfylder kravene i den nordiske miljøsvanemærkeordning.

Publikationen kan bestilles på www.norden.org/order. Flere publikationer på

www.norden.org/publikationer

Printed in Denmark

Nordisk Ministerråd

Store Strandstræde 18

1255 København K

Telefon (+45) 33960200

Fax (+45) 33960202

www.norden.org

\section{Nordisk Råd}

Store Strandstræde 18

1255 København K

Telefon (+45) 33960400

Fax (+45) 33111870

\section{Det nordiske samarbejde}

Det nordiske samarbejde er en af verdens mest omfattende regionale samarbejdsformer. Samarbejdet omfatter Danmark, Finland, Island, Norge og Sverige, samt de selvstyrende områder Færøerne, Grønland og Åland.

Det nordiske samarbejde er både politisk, økonomisk og kulturelt forankret, og er en vigtig medspiller i det europæiske og internationale samarbejde. Det nordiske fællesskab arbejder for et stærkt Norden i et stærkt Europa.

Det nordiske samarbejde ønsker at styrke nordiske og regionale interesser og værdier i en global omverden. Fælles værdier landene imellem er med til at styrke Nordens position som en af verdens mest innovative og konkurrencedygtige regioner. 


\section{Indholdsfortegnelse}

Forord.

Forfatterens forord.

1. Sammenfatning af rapportens indhold

1.1 Indledende klarlægning af omfanget af læsevanskeligheder blandt kortuddannede voksne i Norden...

1.2 Indledende klarlægning af art og omfang af tilbud og tiltag for voksne med utilstrækkelige læse-, stave- og skrivefærdigheder

1.3 Indledende klarlægning: Udvalgte nordiske eksempler på læse-skrivekurser for voksne

1.4 Forslag til kommende projekter.

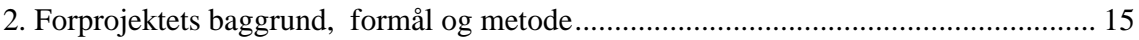

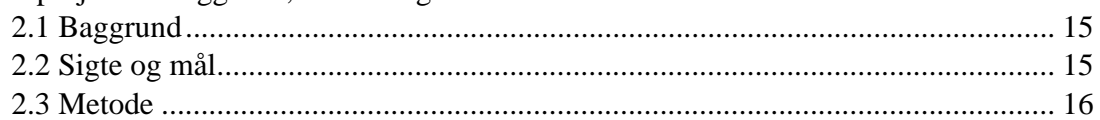

3. Læse- og skrivevanskeligheder blandt kortuddannede i Norden ............................... 19

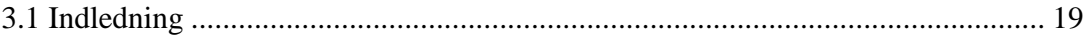

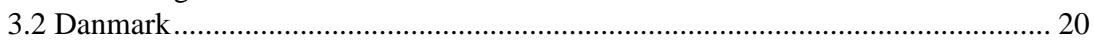

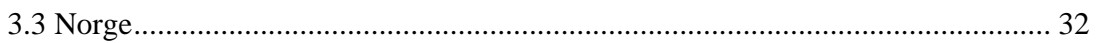

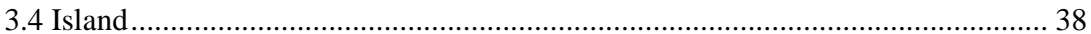

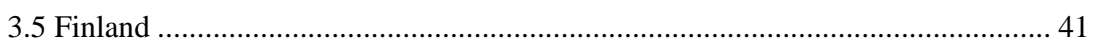

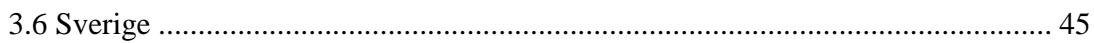

3.7 Diskussion vedrørende omfanget af læse- og skrivevanskeligheder..................... 48

4. Tilbud og tiltag for voksne med utilstrækkelige læse-, stave- og skrivefærdigheder i Norden

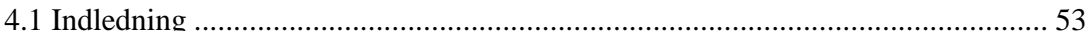

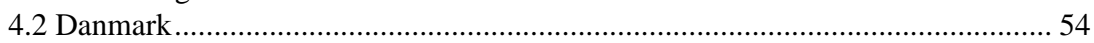

4.3 Norge

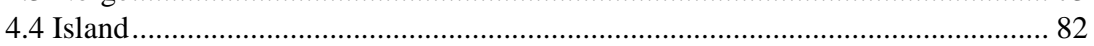

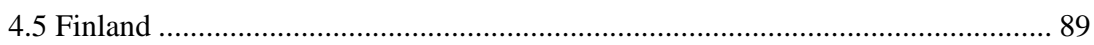

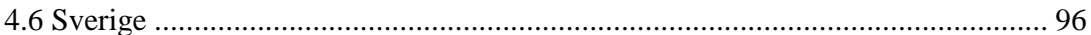

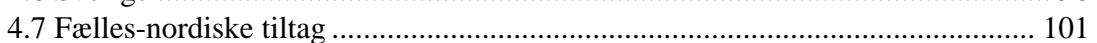

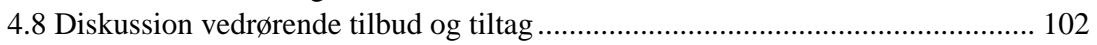

5. Udvalgte nordiske eksempler på læse-skrivekurser for voksne ................................... 107

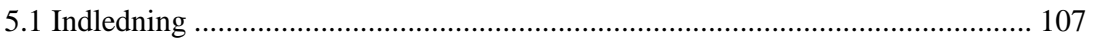

5.2 Et dansk eksempel: Læse-skriveundervisning for kommunalt ansatte

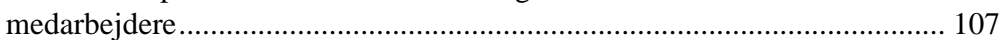

5.3 Et norsk eksempel: Læse-skriveundervisning i AOF .......................................... 112

5.4 Et svensk eksempel: Læse-skriveundervisning for medarbejdere i Volvo .......... 116

5.5 Diskussion vedrørende eksempler på undervisningstiltag .................................. 120

6. Afdækning af krav til og færdigheder i læsning og skrivning i uddannelses-

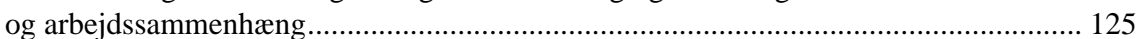

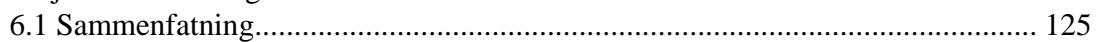

6.2 Krav til og færdigheder i læsning og skrivning ............................................. 126

6.3 Tidligere undersøgelser i uddannelsessammenhæng .......................................... 129 
6.4 Tidligere undersøgelser i arbejdssammenhæng

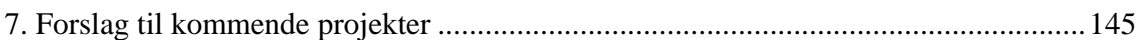

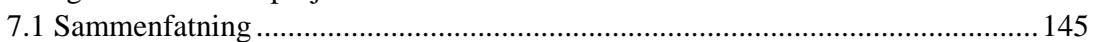

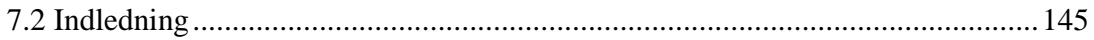

7.3 Projektforslag I: Undersøgelse af effekt af fagrelateret læse-skriveundervisning ............................................................................ 147

7.4 Projektforslag II: Udvikling af metoder til afdækning af uddannelsesrelaterede læse- og skrivekrav samt deltageres færdigheder .........................................149

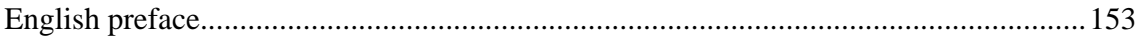

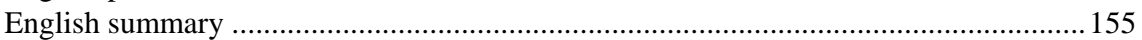

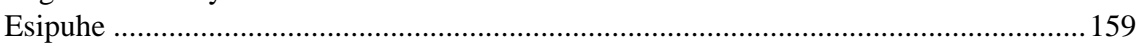

Tiivistelmä raportin sisällöstä ................................................................................... 161

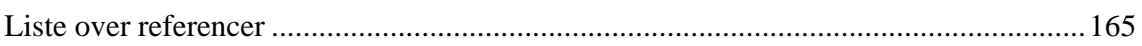

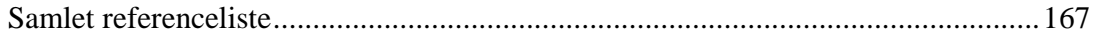

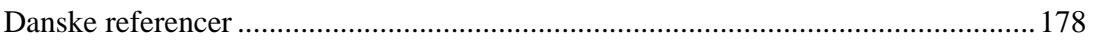

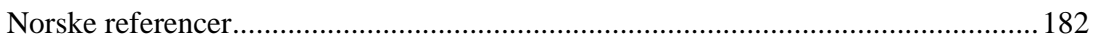

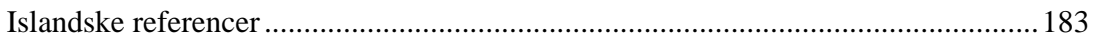

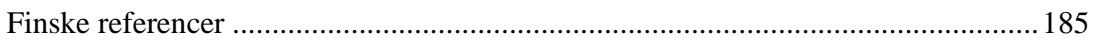

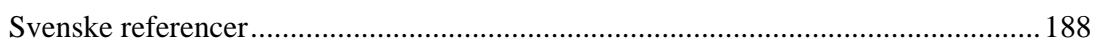

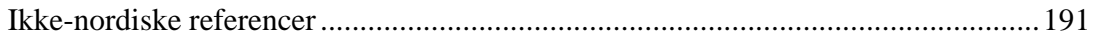




\section{Forord}

Gode leseferdigheter er en avgjørende faktor for at mennesker i en stadig mer kunnskapsbasert verden med rask endringstakt skal kunne delta aktivt både i samfunns- og arbeidsliv. Internasjonale leseundersøkelser viser at de nordiske landene i ulik grad har store utfordringer når det gjelder voksens leseferdigheter. I løpet av de siste årene har Nordisk Ministerråds rådgivningsgruppe for nordisk Samarbeid om Voksnes Læring (SVL), på oppfordring fra de nordiske utdannings- og forskningsministrene, igangsatt en forskningsbaserte forstudie om voksnes leseferdigheter innen rammen for kvalitet i utdanningen.

Formålet med forstudien har i første omgang vært å skaffe innblikk i utfordringer man står overfor knyttet til voksnes leseferdigheter, samt skissere mulige problemstillinger for ytterligere nordisk innsats for å styrke området. Studien har avdekket at

- det er ulike kriterier for, og forståelse av, hva som kjennetegnes leseferdigheter hos kortidsutdannede

- omfanget av hvor mange som har utilstrekkelige ferdigheter varier eksempelvis mellom 20 og 75 \% avhengig av hvilken målemetode som legges til grunn

- det er svak kunnskap om av effekten av tiltak for å bedre lese- og skriveferdighetene

Derfor har forfatterne foreslått å følge opp forstudien med et prosjekt som skal styrke kunnskapsgrunnlaget om hva som virker når det gjelder tiltak for bedre lese- og skriveferdigheter hos kortidsutdannede voksne. Dessuten foreslås også et prosjekt som skal utvikle retningslinjer for hvordan man skal identifisere lese- og skrivekrav og kunne identifisere de personer som har vansker med å leve opp til kravene.

Med bakgrunn i forstudiens anbefalinger vil Nordisk Ministerråds rådgivningsgruppe for nordisk Samarbeid om Voksnes Læring (SVL), arbeide videre med området og beslutte eventuell ytterligere nordisk innsats for å styrke voksnes leseferdigheter.

København den 11.06.07

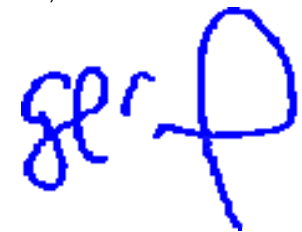

Gard Titlestad

Avdelingssjef, Nordisk Ministerråd 



\section{Forfatterens forord}

Denne rapport er udarbejdet som led i projektet „Forbedring af lcese-, skrive- og IT-fcerdigheder for kortuddannede voksne - en nordisk forundersøgelse“. Projektet er igangsat og finansieret af Styregruppen for Voksnes Læring (SVL) under Nordisk Ministerråd.

Projektet er gennemført i et samarbejde mellem fagpersoner inden for læseområdet fra Danmark, Norge, Sverige, Island og Finland.

Projektledelsen er blevet varetaget af undertegnede (Anna Steenberg Gellert) i samarbejde med Carsten Elbro fra Center for Læseforskning ved Københavns Universitet. Jeg har endvidere stået for indsamling af data fra Danmark, bearbejdning, redaktion og supplering af de indsamlede oplysninger fra de øvrige fire nordiske lande samt udarbejdelse af den samlede rapport til Nordisk Ministerråd. Karina Brunsgaard Bek og Kirstine Bagger Iversen fra Center for Læseforskning har assisteret med praktisk arbejde.

Egil Gabrielsen, Lesesenteret ved Universitetet i Stavanger, har stået for indsamling af data i Norge.

Ingrid Lavås, LäSa-projektet ved Mittuniversitetet i Härnösand, har stået for indsamling af data i Sverige. Andreas Skoglund har assisteret med litteratursøgning.

Rannveig Lund, Lestrarsetur Rannveigar Lund i Reykjavik, har stået for indsamling af data i Island med assistance fra Thora Kristinsdóttir.

Emma Ojanen, Niilo Mäki Instituttet ved Universitetet i Jyväskylä, har stået for indsamling af data i Finland.

Hovedparten af arbejdet med forprojektet er gennemført i 2006. Den samlede rapport blev i slutningen af januar 2007 sendt til gennemsyn og kommentering hos de samarbejdspartnere, som har stået for indsamlingen af data i de enkelte nordiske lande. Som følge af samarbejdspartnernes kommentarer er der foretaget enkelte ændringer i rapporten. Efter aftale med repræsentanter for Styregruppen for Voksnes Læring (SVL) er der endvidere efterfølgende foretaget nogle mindre ændringer inden offentliggørelsen af rapporten.

7. maj 2007

Anna Steenberg Gellert 



\section{Sammenfatning af rapportens indhold}

Denne rapport er udarbejdet i forbindelse med projektet „Forbedring af lase-, skrive- og IT-ferdigheder for kortuddannede voksne - en nordisk forundersøgelse“. Rapporten indeholder resultater fra undersøgelsen og bidrager med en indledende klarlægning inden for tre områder samt forslag til kommende projekter.

\subsection{Indledende klarlægning af omfanget af læsevanskelig- heder blandt kortuddannede voksne i Norden}

Indledende klarlægning af omfanget af læsevanskeligheder blandt kortuddannede voksne i Norden - med særligt henblik på vanskeligheder i forbindelse med arbejde og videreuddannelse inden for fag og erhverv, der tiltrækker mennesker med begrænsede læse- og stavefærdigheder.

Der rapporteres for hvert af de fem nordiske lande Danmark, Norge, Sverige, Finland og Island resultater fra undersøgelser, der kan belyse spørgsmålet om omfanget af læse- og skrivevanskeligheder blandt kortuddannede voksne med særligt henblik på arbejds- og uddannelsesrelaterede forhold (jf. kapitel 3). Undersøgelserne viser entydigt, at der generelt er en meget stærk sammenhæng mellem læsefærdigheder og uddannelsesniveau, og at der er langt flere dårligere læsere blandt kortuddannede end blandt andre voksne.

Imidlertid er der betydelig variation i undersøgelsernes kriterier for, hvad en person skal kunne klare af læseopgaver for at kunne siges at have tilstrækkelige læsefærdigheder. Det er derfor ikke overraskende, at der på basis af undersøgelserne er givet vidt forskellige bud på, hvor mange der har utilstrækkelige læsefærdigheder.

Eksempelvis har en dansk undersøgelse fundet, at cirka $21 \%$ af kortuddannede i arbejde har vanskeligheder med helt dagligdags tekster som $\mathrm{fx}$ en artikel fra et formiddagsblad. De tekster, som indgik i denne undersøgelse, er næppe vanskeligere end det læsestof, kortuddannede møder i deres arbejde og efter al sandsynlighed lettere end det materiale, de kan møde i kursus- og uddannelsessammenhæng inden for deres arbejdsområde.

I flere internationale læseundersøgelser, blandt andet OECDundersøgelsen (Second) International Adult Literacy Survey, lægges der op til, at personer for at kunne siges at have en funktionel læsefærdighed skal være i stand til at bruge læsning som led i en personlig udvikling, fx 
i uddannelsessammenhænge, hvor der typisk skal læses relativt svære tekster. I tråd hermed er hovedparten af de anvendte tekster og opgaver i OECD-undersøgelsen væsentligt vanskeligere end dem, der indgik i den ovenfor nævnte danske undersøgelse. OECD-undersøgelsen finder tegn på, at mellem halvdelen og tre fjerdedele af de kortuddannede voksne i Danmark, Norge, Finland og Sverige har utilstrækkelige læsefærdigheder.

Det er vanskeligt at fastslå omfanget af læsevanskeligheder blandt kortuddannede i arbejdssammenhæng, hvilket hænger sammen med, at sådanne eventuelle vanskeligheder må afhænge af de læsekrav, som de kortuddannede faktisk møder. Der findes kun ganske få nordiske undersøgelser, der fokuserer på de læsekrav, der stilles til kortuddannede voksne i arbejds- og uddannelsessammenhænge. Et bud på omfanget af læsevanskeligheder blandt kortuddannede i Norden må derfor nødvendigvis være forbundet med stor usikkerhed, men det forekommer rimeligt på basis af den omtalte undersøgelse af danskeres læsefærdigheder at fastslå et mindstetal på omkring $20 \%$. Det faktiske tal kan meget vel være væsentligt højere, især hvis man, som den omtalte OECD-undersøgelse lægger op til, også kræver, at kortuddannede skal kunne bruge læsning som led i en personlig udvikling, fx i kursus- og uddannelsessammenhænge.

Da der som nævnt kun er foretaget relativt få nordiske undersøgelser af læse- og skrivekrav i arbejde og uddannelse, er der i rapporten også inddraget resultater fra undersøgelser gennemført uden for Norden (jf. kapitel 6). I arbejdssammenhœeng er læse- og skrivekravene blandt andet blevet undersøgt gennem observationer af arbejdssituationer, medarbejderes egne notater vedrørende omfanget og karakteren af deres læsning og skrivning samt interviews med ledere og medarbejdere. Endvidere er der foretaget indsamlinger og analyser af de materialer, som blev anvendt på de undersøgte arbejdspladser. Sådanne undersøgelser viser, at voksne med praktisk betonet arbejde ofte kun læser kort tid ad gangen i forbindelse med udførelsen af arbejdsfunktionerne. Tekster bruges typisk til at slå enkelte oplysninger op i, mens skrivning ofte foregår i korte sætninger, enkelte ord og koder. Derudover kan der indgå mere omfattende læsning og skrivning i forbindelse med fx dokumentation af det udførte arbejde, mødedeltagelse, planlægning af arbejdsprocesser og kvalitetskontrol. Betydningen af læsning og skrivning varierer betydeligt mellem forskellige jobs, men specielt krav om skriftlig dokumentation synes at spille en stadig større rolle, også i en række jobs, der ikke forudsætter noget højt uddannelsesniveau.

I uddannelsessammenhæeng er der i tidligere undersøgelser med henblik på afdækning af kravene til læsning og skrivning blandt andet gennemført observationer af undervisningssituationer, indsamlinger og analyser af de materialer, som indgik i undervisningen, samt interviews med undervisere og deltagere. Disse undersøgelser tyder på, at der i mange praktisk orienterede uddannelser indgår en del relativt tungt læsestof. 
Imidlertid er der store forskelle med hensyn til, hvor vigtig en rolle læsning spiller for deltagernes tilegnelse af faglig viden. På nogle uddannelser er læsning af fagtekster således en vigtig kilde til faglig indsigt, mens denne indsigt på andre uddannelser til en vis grad kan tilegnes på anden vis. Ligeledes lægges der på nogle praktisk orienterede uddannelser stor vægt på dokumentation af faglig viden gennem opgaveskrivning, hvorimod skrivning ikke spiller så stor en rolle i andre uddannelser.

\subsection{Indledende klarlægning af art og omfang af tilbud og tiltag for voksne med utilstrækkelige læse-, stave- og skrivefærdigheder}

Der er i Danmark, Norge, Sverige, Finland og Island indsamlet data om følgende typer af tilbud og tiltag:

- Tilbud og tiltag i arbejds- og fritidssammenhænge for voksne med læse-, stave- og skrivevanskeligheder, herunder ordblinde.

- Støtteforanstaltninger i uddannelsessammenhænge for personer med læse-, skrive- og stavevanskeligheder (med særligt henblik på foranstaltninger i formelt kompetencegivende uddannelser, som er praktisk orienterede og/eller rettede mod kortuddannede voksne).

- Særlige tilbud for indvandrere m.fl. (med særligt henblik på tilbud, som specifikt sigter mod at forbedre læse-, skrive- og IT-færdigheder hos personer med et andet modersmål end majoriteten i landet).

Inden for disse områder beskrives en række forskellige tilbud og tiltag i de enkelte nordiske lande (jf. kapitel 4). Det påpeges, at der i mange tilfælde ikke foreligger overbevisende dokumentation for effekten af de beskrevne tiltag. Det er derfor vanskeligt at vurdere, om de forskellige tiltag med fordel kan efterlignes og implementeres i andre sammenhænge.

\subsection{Indledende klarlægning: Udvalgte nordiske eksempler på læse-skrivekurser for voksne}

I forbindelse med forprojektet er der indsamlet data fra nogle eksempler på tiltag, der sigter mod at reducere læse- og skrivevanskeligheder blandt voksne (jf. kapitel 5). Det ene eksempel er et dansk forløb i forberedende voksenundervisning (FVU) i læsning, stavning og skriftlig fremstilling for medarbejdere i en kommunal døgnpleje og køkken/service-afdeling. Det andet eksempel er et norsk læse- og skrivekursus inden for Arbeidernes Opplysningsforbund (AOF). Det tredje eksempel er et tilbud om individuelt tilrettelagt læse- og skriveundervisning på virksomheden Volvo i Sverige. 
De tre indsamlede eksempler på tiltag beskrives og vurderes. I alle de rapporterede tiltag indgår der elementer, der sandsynligvis vil kunne inspirere andre udbydere og undervisere, men det påpeges, at det er vanskeligt at vide med sikkerhed, om de beskrevne tiltag faktisk er bedre end så mange andre tiltag og således værd at kopiere. Dette skyldes blandt andet, at der ikke ud fra beskrivelserne er noget pålideligt grundlag for at vurdere, om de anvendte metoder gavner voksne deltagere mere end andre metoder. Hvis man vil vide, om anvendelse af bestemte metoder inden for læse- og skriveundervisning fører til bedre resultater end andre metoder, er gennemførelse af egentlige effektundersøgelser den mest sikre vej til at opnå denne viden.

\subsection{Forslag til kommende projekter}

På basis af resultaterne af forprojektet fremsættes der afslutningsvis i rapporten to forslag til kommende projekter (jf. kapitel 7).

Som nævnt ovenfor savnes der undersøgelser af virkningen af forskellige typer af læse- og skriveundervisning. På denne baggrund fremsættes der et forslag, som har til formål at undersøge effekten af et særligt tilrettelagt læse- og skriveundervisningsforløb, hvor der tages udgangspunkt i de krav, deltagerne møder i deres arbejde eller uddannelse (projektforslag I).

Der savnes endvidere retningslinjer for, hvordan læse- og skrivekrav kan afdækkes og synliggøres på en systematisk måde, lige som der er brug for velafprøvede metoder til at identificere de personer, der har vanskeligheder med at leve op til disse krav. Der fremsættes derfor et forslag til et projekt, som kan bidrage til udvikling af sådanne retningslinjer og metoder i uddannelsessammenhæng (projektforslag II). 


\section{Forprojektets baggrund, formål og metode}

\subsection{Baggrund}

Unges og voksnes læsefærdigheder er under pres i Norden. Dels er der sket en betydelig bogliggørelse af alle uddannelserne i de traditionelt „håndværksmæssige“ eller „praktiske“ fag. Det gælder såvel for de erhvervsfaglige grunduddannelser som for arbejdsmarkedsuddannelserne. Dels har automatisering, strammere kvalitetsprocedurer og outsourcing af ufaglært arbejde reduceret andelen af jobs med beskedne krav til læsefærdighederne og medført markant voksende læsekrav i arbejdsfunktioner, som ikke tidligere krævede megen læsning.

En international undersøgelse har fundet, at en relativt stor del af de voksne i Norden havde vanskeligheder med at læse tekster. ${ }^{1}$ Således klarede omkring en tredjedel af deltagerne i de nordiske lande sig under det niveau, som i undersøgelsen blev fastlagt som minimumskriterium. Omfanget af kortuddannedes vanskeligheder med læsning i forbindelse med arbejde og uddannelse er imidlertid stadig dårligt belyst. Dette skyldes især, at eventuelle læsevanskeligheders omfang er ganske afhængigt af læsekravene, og disse krav varierer stærkt mellem uddannelser og mellem arbejdsfunktioner.

I de nordiske lande findes der mange forskellige tilbud og tiltag, der retter sig mod voksne med læsevanskeligheder. Der findes imidlertid ikke noget nordisk overblik over disse tilbud og tiltag. Endvidere er der kun gennemført få undersøgelser af undervisningstilbuddenes effekt.

\subsection{Sigte og mål}

Forprojektet skal bidrage med en indledende klarlægning på følgende tre områder:

1 Omfanget af læsevanskeligheder blandt kortuddannede voksne i

Norden - med særligt henblik på vanskeligheder i forbindelse med arbejde og videreuddannelse inden for fag og erhverv, der tiltrækker mennesker med begrænsede læse- og stavefærdigheder. Målet med forprojektet er at indsamle, vurdere og sammenfatte eksisterende

\footnotetext{
${ }^{1}$ OECD (2000). Literacy in the Information Age: Final Report of the International Adult Literacy Survey. Paris: OECD.
} 
dokumentation fra alle de nordiske lande. Desuden er det målet at udforme retningslinjer for en fremgangsmåde ved kvantificering af specifikke læsekrav i en given uddannelse eller arbejdsfunktion. Kvantificeringen skal indebære en undersøgelse af mulighederne for brobygning til allerede eksisterende læse-stavetest.

2 Art og omfang af private og offentlige tilbud om screening af læsestavefærdigheder og læse-staveundervisning. Målet med forprojektet er at indsamle og sammenfatte den eksisterende dokumentation af de offentlige tilbud i de nordiske lande - og eksempler på initiativer i private virksomheder eller organisationer.

3 Effektive tiltag, der kan reducere eventuelle læse- og stavevanskeligheder. Målet med forprojektet er at indsamle, vurdere og sammenfatte et lovende eksempel fra hvert af mindst tre af de nordiske lande.

Blandt andet vil det være ønskeligt at kunne bidrage med eksempler på løsning af rekrutteringsproblemet - dvs. at mennesker med læsevanskeligheder undviger tilbud om læsekrævende kurser og uddannelse, og med eksempler på læse-staveundervisning, der er integreret i den faglige undervisning og som $\mathrm{fx}$ tilbyder læseundervisning $\mathrm{i}$ netop de tekster og det ordforråd, der hører til et givet fag eller en given jobfunktion.

\subsection{Metode}

Projektledelsen i Danmark har udvalgt samarbejdspartnere i de nordiske lande og udformet guidelines for indsamling af oplysninger inden for hvert af de ovenfor beskrevne områder. Samarbejdspartnerne har så vidt muligt indsamlet og rapporteret de ønskede oplysninger. Hovedindsamlingen af oplysningerne er af praktiske grunde tidsmæssigt blevet gennemført en smule forskudt i de enkelte lande:

- I Danmark i perioden maj 2006-januar 2007

- I Norge i april 2006-juni 2006

- I Island i maj 2006-juni 2006

- I Finland i april 2006-oktober 2006

- I Sverige august 2006-december 2006.

De indsamlede oplysninger er af projektledelsen blevet kontrolleret, bearbejdet og suppleret gennem yderligere forespørgsler, litteratursøgning m.v.. Der er i litteratursøgningen lagt vægt på at finde frem til beskrivelser af relevante nordiske tilbud, initiativer og projekter. Derudover har projektledelsen valgt at inddrage resultater fra flere ikke-nordiske forsknings- og udviklingsprojekter, som vurderes som relevante i forhold til de problemstillinger, som behandles i forbindelse med forprojektet. 
De indsamlede oplysninger afrapporteres i bearbejdet form i denne rapport. Fremstillingen af oplysningerne om de enkelte lande er inden afleveringen af rapporten til Styregruppen for Voksnes Læring i februar 2007 blevet ajourført, kommenteret og godkendt af de personer, der har været ansvarlige for indsamlingen. 



\section{Læse- og skrivevanskeligheder blandt kortuddannede i Norden}

\subsection{Indledning}

Forprojektet skal bidrage med en indledende afklaring af omfanget af læse- og skrivevanskeligheder blandt kortuddannede voksne i Norden med særligt henblik på vanskeligheder i forbindelse med arbejde og videreuddannelse inden for fag og erhverv, der tiltrækker mennesker med begrænsede læse- og stavefærdigheder. Målet med forprojektet er at indsamle, vurdere og sammenfatte eksisterende dokumentation fra alle de nordiske lande.

Der rapporteres i det følgende for hvert af de fem nordiske lande resultater fra undersøgelser, der kan belyse spørgsmålet om omfanget af læse- og skrivevanskeligheder blandt kortuddannede voksne med særligt henblik på arbejds- og uddannelsesrelaterede forhold. Indledningsvis gives der for hvert land en sammenfatning af de vigtigste resultater af de undersøgelser, som er gennemført i det pågældende land. Derefter gives der en mere grundig beskrivelse af resultaterne, idet undersøgelserne gennemgås tematisk under følgende overskrifter:

- Undersøgelser af kortuddannedes læse-, stave- og skrivefærdigheder

- Undersøgelser vedrørende læsning og skrivning i arbejdssammenhæng

- Undersøgelser vedrørende læsning og skrivning i uddannelses- og kursussammenhæng

I undersøgelserne af læsning og skrivning i uddannelses- og kursussammenhæng fokuseres der på uddannelser og kurser, der er praktisk orienterede og/eller rettede mod kortuddannede voksne.

I de tilfælde, hvor der foreligger flere undersøgelser inden for samme delområde, rapporteres den nyeste undersøgelse først og derefter de ældre undersøgelser.

På basis af undersøgelserne er det ikke altid muligt at skelne mellem data fra voksne over 18 og unge under 18 år, da nogle undersøgelser omfatter begge grupper. Derfor indgår der i beskrivelsen af nogle af undersøgelserne ikke kun data fra voksne, men også data fra unge under myndighedsalderen.

For alle de beskrevne undersøgelser gælder det, at de rapporterede resultater bør tages med forbehold. Dels kan der være metodiske problemer i undersøgelserne, dels kan forhold som befolkningssammensætning og 
organisering af de undersøgte uddannelsestilbud have ændret sig siden gennemførslen af de rapporterede undersøgelser. Nogle af disse problemer behandles i diskussionsafsnittet 3.7, der afrunder kapitlet om undersøgelser af læse- og skrivevanskeligheder blandt kortuddannede i Norden.

\subsection{Danmark}

3.2.1 Sammenfatning af resultater af undersøgelser vedrørende omfanget af læesevanskeligheder blandt kortuddannede i Danmark

I OECD's undersøgelse Second International Adult Literacy Survey (SIALS) blev der indsamlet data fra Danmark i 1998 (jf. afsnit 3.2.2.1). De ufaglærte var stærkt overrepræsenterede blandt de dårlige læsere i den danske del af SIALS. Således placerede omkring 79 \% af denne gruppe sig på en test af læsning under det kompetenceniveau, som ifølge OECD er nødvendigt for at kunne „bruge trykt og skreven information med henblik på at fungere i samfundet, opnå sine mål, udvikle sin viden og sit potentiale og deltage i samfundet“. Til sammenligning befandt „kun“ $46 \%$ af de undersøgte danskere sig som helhed under dette niveau.

På basis af en national undersøgelse af danskernes læsefærdigheder blev det i 1991 vurderet, at omkring 21 \% af de ufaglærte, som var i arbejde, ikke læste godt nok til at kunne klare almindelige, lette dagligdags tekster (jf. afsnit 3.2.2.2). Det var væsentligt flere end de $12 \%$ blandt alle deltagerne i undersøgelsen og godt tre gange så mange som blandt andre i arbejde. De ufaglærte var således også i denne undersøgelse stærkt overrepræsenterede blandt de dårlige læsere, men den estimerede andel af personer med vanskeligheder var væsentligt lavere end i OECDundersøgelsen, hvad angår såvel voksenbefolkningen som helhed som de ufaglærte i særdeleshed. De store forskelle i tallene kan skyldes flere forhold, men især, at kriterierne for, hvad en person skal kunne klare af læseopgaver, er vidt forskellige i de beskrevne undersøgelser. Denne problemstilling behandles nærmere i diskussionsafsnittet 3.7.

Der er gennemført flere undersøgelser, der på forskellig vis kan belyse kortuddannede danskeres læsning og skrivning i arbejdssammenhæenge. Det fremgår af disse undersøgelser, at ufaglærte danskere generelt læser og skriver relativt lidt på jobbet i sammenligning med personer, der har afsluttet en uddannelse efter grundskolen (jf. afsnit 3.2.3.2), lige som denne gruppe i mindre omfang bruger computer i deres arbejde (jf. 3.2.3.1). Adspurgt oplyser relativt få af de ufaglærte, at de oplever vanskeligheder med at læse og skrive på jobbet (jf. 3.2.3.1. og 3.2.3.3).

En interviewundersøgelse blandt arbejdsgivere inden for handels-, transport- og serviceerhvervene har vist, at $66 \%$ af de adspurgte oplevede, at der i deres virksomhed var medarbejdere med læse- og/eller staveproblemer. Blandt de arbejdsgivere, der mente, at de havde medarbejdere 
med sådanne problemer, oplevede de $29 \%$, at dette medfører vanskeligheder i det daglige arbejde.

I uddannelsessammenhœenge er der gennemført flere danske undersøgelser af læse- og stavefærdighederne blandt kortuddannede deltagere. Eksempelvis viste en undersøgelse blandt kursister i den almene voksenuddannelse (AVU), at der var en relativt stærk sammenhæng mellem kursisternes læsefærdigheder og deres eksamenskarakterer (jf. 3.2.4.2). Især de kursister, som lå blandt de dårligste 10 \% på en test af læseforståelse, fik generelt meget lave karakterer i skriftsprogstunge fag. En anden undersøgelse blandt deltagere i arbejdsmarkeds- og erhvervsuddannelser viste, at omkring $40 \%$ af de undersøgte havde læse- og stavefærdigheder, der højst svarede til gennemsnittet for skoleelever midt i 5 . klasse (jf. 3.2.4.4).

For en diskussion af de ovenfor sammenfattede resultater og temaer henvises til afsnit 3.7.

3.2.2 Undersøgelser af kortuddannedes lase-, stave- og skrivefcerdigheder

3.2.2.1 Omfanget af læsevanskeligheder blandt voksne danskere med særligt fokus på ufaglærte - belyst ved delresultater fra Second International Adult Literacy Survey (SIALS)

\section{A. Omfanget af lesevanskeligheder i den voksne befolkning som helhed}

Konsortiet bag (S)IALS har opstillet fem læsefærdighedsniveauer, hvor niveau 3 antages at angive det minimumsniveau af færdigheder, der er nødvendige for at kunne klare de krav, der stilles på arbejde og i dagligdagen. For en beskrivelse af de krævede færdigheder på de forskellige niveauer henvises der til afsnit 6.4.1.3 i nærværende rapport samt til OECD's rapporter om (S)IALS. ${ }^{2}$

I alt 3.028 personer mellem 16 og 66 år deltog i den danske del af SIALS, som blev gennemført i 1998. ${ }^{3}$ På en test af leesning af fortløbende tekster som avisartikler og brochurer (,prose literacy“) klarede knap halvdelen (46 \%) af de danske deltagere sig så ringe, at de ikke levede op til det af OECD fastsatte minimumskriterium. Således opnåede 9,6 \% af de danske deltagere resultater, der svarer til niveau 1, dvs. det laveste af OECD's fem niveauer, mens $36,4 \%$ af deltagerne befandt sig på niveau 2. På en test af forståelse af dokumenttekster som fx tidstabeller, diagrammer, kort og blanketter (,document literacy“) klarede de danske deltagere sig relativt bedre, idet „kun“ 32 \% her scorede under OECD’s minimumskriterium. Således befandt $7,8 \%$ sig ifølge denne test på ni-

\footnotetext{
${ }^{2}$ Fx: OECD (2000). Literacy in the Information Age: Final Report of the International Adult Literacy Survey. Paris: OECD.

${ }^{3}$ Jensen, T.P. \& Holm, A. (2000). Danskernes læse-regne-færdigheder - i et internationalt lys. København: AKF Forlaget.
} 
veau 1 og 24,2 \% på niveau 2. Blandt deltagerne på de laveste færdighedsniveauer var der forholdsvis mange, der var pensionister og hjemmegående og således stod uden for arbejdsmarkedet. Jensen \& Holm (2000) har på basis af de danske data fra SIALS beregnet, at mellem 0,8 og 1,3 millioner danskere på undersøgelsestidspunktet befandt sig på de to laveste færdighedsniveauer, hvis der sås bort fra de pensionerede og hjemmegående. De tilsvarende tal for det laveste færdighedsniveau var mellem 150.000 og 200.000 danskere.

Det bemærkes, at Trepartsudvalget på basis af de danske resultater fra SIALS har givet et estimat af antallet af danskere med utilstrækkelige læsefærdigheder i 2006. ${ }^{4}$ Dette udvalg er nedsat af den danske regering med henblik på at tilvejebringe grundlaget for videre drøftelser mellem regeringen og arbejdsmarkedets parter om mulighederne for at fremme målsætningen om livslang opkvalificering og uddannelse for alle. Udvalget vurderer, at OECD’s krav til basale færdigheder er sat relativt højt, og påpeger, at uddannelsesniveauet og befolkningssammensætningen er ændret siden Danmarks deltagelse i SIALS i 1998. På denne baggrund skønner Trepartsudvalget, at antallet af danskere med utilstrækkelige læsefærdigheder i 2006 kan nedskrives til omkring 800.000 på de to laveste niveauer og 150.000 personer på det laveste niveau.

\section{B. Omfanget af laesevanskeligheder blandt ufaglerte}

På grundlag af data fra den ovenfor omtalte danske del af SIALS foretog Jensen, Andersen \& Halgreen (2001) en række særskilte analyser med fokus på ufaglærte (det vil sige personer, som ikke har afsluttet nogen kompetencegivende uddannelse efter grundskolen). ${ }^{5}$ Analyserne viste, at de ufaglærte var stærkt overrepræsenterede blandt de dårlige læsere i den danske del af SIALS.

Således befandt $28 \%$ af de ufaglærte sig på niveau 1 på testen af læesning af fortløbende tekster (,prose literacy“), mens $51 \%$ af de ufaglærte var på niveau 2. Sammenlagt lå i alt $79 \%$ af de ufaglærte på denne læsetest under det kompetenceniveau, som ifølge OECD er nødvendigt. Til sammenligning befandt omkring $52 \%$ af deltagerne med en erhvervsfaglig uddannelse sig under det af OECD fastlagte minimumskriterium, idet cirka $8 \%$ af deltagerne fra denne gruppe klarede sig på niveau 1 og cirka $45 \%$ på niveau 2. Blandt deltagerne med en videregående uddannelse (universitetsuddannelse eller lignende) befandt cirka $2 \%$ sig på niveau 1 og cirka $17 \%$ sig på niveau $2 .^{6}$

\footnotetext{
${ }^{4}$ Trepartsudvalget (2006). Livslang opkvalificering og uddannelse for alle på arbejdsmarkedet rapport fra Trepartsudvalget - Bind 1: Den fremtidige voksen- og efteruddannelsesindsats. København: Finansministeriet. (http://www.fm.dk/1024/visPublikationesForside.asp?artikelID=8112)

${ }^{5}$ Jensen, T.P., Andersen, A. \& Halgreen, T. (2001). Leeseferdigheder og deltagelse i samfundslivet. København: Amternes og Kommunernes Forskningsinstitut \& Specialarbejderforbundet i Danmark.

${ }^{6}$ Det bemærkes, at de angivne tal for deltagere med erhvervsfaglig og videregående uddannelse er omtrentlige, idet de ikke fremgår entydigt af rapporten, men har måttet aflæses skønsmæssigt på basis af diagrammer i rapporten.
} 
Ifølge Jensen et al. gjorde den samme tendens sig gældende med hensyn til de ufaglærtes resultater på testen af dokumentforståelse („,document literacy“), idet der også her var langt flere blandt de ufaglærte end de uddannede, som klarede sig dårligt.

Analyserne viste endvidere, at gruppen af ufaglærte gennemsnitligt i mindre omfang deltog i kurser med et erhvervsmæssigt/fagligt formål end personer med en uddannelse ud over grundskolen. Dette gjaldt i særlig grad for de ufaglærte med ringe læsefærdigheder; således havde kun cirka 20 \% af de ufaglærte med færdigheder på niveau 1 deltaget i voksen- og efteruddannelse inden for det sidste år, hvorimod cirka $75 \%$ af personerne med en erhvervsfaglig eller gymnasial uddannelse med et tilsvarende færdighedsniveau havde deltaget i sådanne aktiviteter. Derimod var ufaglærte med læsefærdigheder på niveau 4/5 næsten lige så kursusaktive som personer med uddannelse.

3.2.2.2 Omfanget af læsevanskeligheder blandt voksne danskere med særligt fokus på ufaglærte i arbejde - belyst ved resultater fra national undersøgelse af voksne danskeres læsefærdigheder

\section{A. Omfanget af licesevanskeligheder i den voksne befolkning som helhed}

Elbro, Møller \& Nielsen (1991) gennemførte en undersøgelse af omfanget af læsevanskeligheder med dagligdags tekster i den voksne befolkning mellem 18 og 67 år. $^{7} 1124$ repræsentativt udvalgte voksne i denne aldersgruppe besvarede spørgsmål om læsefærdigheder og læsevaner. Endvidere deltog 445 af de interviewede i en test af læsning af følgende dagligdags tekster:

1 fortællende tekster (artikel fra formiddagsbladet B.T.)

2 informerende tekster (pjece om brand + skat)

3 opslagstekster (bykort + pristabel fra rejsebureau)

4 udfyldningstekster (postblanket).

Til hver af teksterne blev der stillet opgaver, som dækker, hvad teksterne normalt bruges til. Forfatterne vurderede på grundlag af undersøgelsens resultater, at omkring $12 \%$ af de voksne kunne betegnes som dårlige læsere, idet de havde markante vanskeligheder med mindst halvdelen af de dagligdags tekster, som indgik i undersøgelsen.

\section{B. Omfanget af læesevanskeligheder blandt ufaglerte}

På basis af data fra den ovenfor beskrevne undersøgelse gennemførte Møller \& Elbro (1992) en supplerende analyse af ufaglærte arbejderes

\footnotetext{
${ }^{7}$ Elbro, C., Møller, S. \& Nielsen, E. M. (1991). Danskernes læesefærdigheder. En undersøgelse af 18 - 67-åriges lasning af dagligdags tekster. København: Projekt Læsning og Undervisningsministeriet.
} 
læsning set i relation til andre voksne danskeres læsning. ${ }^{8}$ Forfatterne vurderede, at omkring $21 \%$ af de ufaglærte, som var i arbejde, ikke læste godt nok til at kunne klare almindelige dagligdags tekster. Det var væsentligt flere end de $12 \%$ blandt alle deltagerne i undersøgelsen og godt tre gange så mange som blandt andre i arbejde. De ufaglærte arbejdere var således stærkt overrepræsenterede blandt de dårlige læsere.

De ufaglærte, som på grundlag af deres præstationer på læseprøven blev defineret som dårlige læsere, vurderede deres egne læsefærdigheder signifikant lavere end andre grupper, som også var dårlige læsere. Der var faktisk i undersøgelsen ingen anden gruppe, som på trods af læsefærdigheder på omtrent samme niveau vurderede sig selv så lavt som de ufaglærte. De grupper, de ufaglærte blev sammenlignet med, var: selvstændige, funktionærer/tjenestemænd, faglærte, husmødre, pensionister, arbejdsløse. 3.2.3. Undersøgelser vedrørende læsning og skrivning i arbejdssammenhæng

3.2.3.1 Kortuddannede danskeres læsning, skrivning og brug af IT i arbejdssammenhæng - belyst ved resultater fra „Det Nationale Kompetenceregnskab“

Undervisningsministeriet (2005) har gennemført og beskrevet et udviklingsprojekt med overskriften „Det Nationale Kompetenceregnskab“. ${ }^{9}$ I projektet er voksne danskeres kompetencer blevet kortlagt inden for en række nøgleområder, herunder læsning og skrivning. Undersøgelsen blev gennemført telefonisk ved hjælp af et individbaseret spørgeskema. Et repræsentativt udsnit af befolkningen på 7954 personer er blevet kontaktet med henblik på at besvare en række spørgsmål, der gør det muligt at analysere og beskrive danskernes nøglekompetencer. Danmarks Statistik stod for den tekniske side af undersøgelsen, som blev gennemført i vinteren 2003-04. I det følgende gengives nogle resultater fra „Det Nationale Kompetenceregnskab " af relevans for det nordiske forprojekt om kortuddannede voksnes læsning.

Deltagerne i undersøgelsen blev blandt andet spurgt om, hvor svært eller let de havde ved at læse det, de skulle i forbindelse med deres arbejde. Som tabellen nedenfor viser, svarede langt hovedparten af de adspurgte, at de fandt det let eller meget let, mens kun relativt få fandt det svært eller meget svært. Blandt de ufaglærte arbejdere og specialarbejdere oplyste i alt cirka $94 \%$, at de fandt det let eller meget let at læse det, de skulle i forbindelse med deres arbejde, mens kun cirka $5 \%$ fandt det svært eller meget svært. Procentvis var andelen af ufaglærte og specialarbejdere, der fandt det let eller meget let at læse det, de skulle, faktisk højere end blandt andre grupper som fx faglærte arbejdere og funktionæ-

\footnotetext{
${ }^{8}$ Møller, S. \& Elbro, C. (1992). Ufaglærtes læsning. En undersøgelse af ufaglærte arbejderes læsning set i relation til andre voksnes læsning. København: Specialarbejderforbundet i Danmark (SID).

${ }^{9}$ Undervisningsministeriet (2005). Det Nationale Kompetenceregnskab - Hovedrapport. København: Undervisningsministeriet. (http://pub.uvm.dk/2005/NKRrapport/)
} 
rer. Tilsvarende var andelen af ufaglærte og specialarbejdere, der fandt det svært eller meget svært, relativt lav. Forfatterne til rapporten vurderer, at dette formodentlig hænger sammen med, at mange af de kortuddannede har jobs, som ikke stiller særlig store krav til deres færdigheder i læsning.

Tabel 1: Vurdering af sværhedsgraden af arbejdsrelaterede læseopgaver blandt undersøgelsesdeltagere i „Det Nationale Kompetenceregnskab“ ${ }^{10}$

\begin{tabular}{lccccc}
\hline Hvor svært eller let er det for dig at læse det, du skal i forbindelse med dit arbejde? & & & Leget \\
Stilling & let & Let & Svært & $\begin{array}{r}\text { Meget } \\
\text { svært }\end{array}$ & $\begin{array}{r}\text { Hoved- } \\
\text { total }\end{array}$ \\
\hline Ikke faglært arbejder/ specialarbejder & $28 \%$ & $66 \%$ & $3 \%$ & $2 \%$ & $100 \%$ \\
Faglært arbejder & $22 \%$ & $69 \%$ & $9 \%$ & $0 \%$ & $100 \%$ \\
Funktionær/ tjenestemand i øvrigt & $21 \%$ & $68 \%$ & $10 \%$ & $1 \%$ & $100 \%$ \\
Ledende funktionær el. ledende tjenestemand & $31 \%$ & $64 \%$ & $4 \%$ & $1 \%$ & $100 \%$ \\
Andet arbejde & $23 \%$ & $77 \%$ & $0 \%$ & $0 \%$ & $100 \%$ \\
Selvstændig & $25 \%$ & $67 \%$ & $7 \%$ & $1 \%$ & $100 \%$ \\
Hovedtotal & $24 \%$ & $68 \%$ & $8 \%$ & $1 \%$ & $100 \%$ \\
\hline
\end{tabular}

Endvidere blev deltagerne i undersøgelsen spurgt om, hvor ofte de skulle bruge computer som led i deres arbejde. Som det fremgår af tabellen nedenfor, skulle personer uden nogen uddannelse ud over folkeskolen i mindre grad anvende computere i arbejdssammenhæng end andre grupper. Således skulle $45 \%$ af deltagerne med folkeskolen som højeste uddannelsesniveau slet ikke bruge computer, mens dette eksempelvis kun gjaldt for $26 \%$ af deltagerne med en erhvervsfaglig uddannelse og $18 \%$ af deltagerne med en gymnasial uddannelse som højeste uddannelsesniveau.

Tabel 2: Brug af computer i arbejdssammenhæng blandt undersøgelsesdeltagere i "Det Nationale Kompetenceregnskab“ ${ }^{11}$

\begin{tabular}{|c|c|c|c|c|c|}
\hline \multicolumn{6}{|c|}{ Hvor ofte skal du bruge computer som led i dit arbejde? } \\
\hline Uddannelse & Dagligt & Ugentligt & $\begin{array}{r}\text { SjæIdnere } \\
\text { end } \\
\text { ugentligt }\end{array}$ & $\begin{array}{r}\text { Skal slet ikke } \\
\text { bruge } \\
\text { computer } \\
\text { som en del af } \\
\text { mit arbejde }\end{array}$ & $\begin{array}{l}\text { Hoved- } \\
\text { total }\end{array}$ \\
\hline $\begin{array}{l}\text { Lang videregående uddannelse } \\
\text { (over } 4 \text { år) }\end{array}$ & $94 \%$ & $4 \%$ & $1 \%$ & $1 \%$ & $100 \%$ \\
\hline $\begin{array}{l}\text { Mellemlang videregående uddannelse } \\
\text { (3-4 år) }\end{array}$ & $77 \%$ & $12 \%$ & $5 \%$ & $6 \%$ & $100 \%$ \\
\hline $\begin{array}{l}\text { Kort videregående uddannelse } \\
\text { (under } 3 \text { år) }\end{array}$ & $85 \%$ & $4 \%$ & $1 \%$ & $10 \%$ & $100 \%$ \\
\hline Studentereksamen/hf/hh/htx/hhx & $74 \%$ & $5 \%$ & $4 \%$ & $18 \%$ & $100 \%$ \\
\hline Folkeskole til og med 10. klasse & $45 \%$ & $4 \%$ & $7 \%$ & $45 \%$ & $100 \%$ \\
\hline Erhvervsfaglig uddannelse & $64 \%$ & $6 \%$ & $4 \%$ & $26 \%$ & $100 \%$ \\
\hline Hovedtotal & $69 \%$ & $6 \%$ & $4 \%$ & $20 \%$ & $100 \%$ \\
\hline
\end{tabular}

${ }^{10}$ Bilag til: Undervisningsministeriet (2005). Det Nationale Kompetenceregnskab - Hovedrapport. København: Undervisningsministeriet. (http://pub.uvm.dk/2005/NKRresume/a.xls)

${ }^{11}$ Bilag til: Undervisningsministeriet (2005). Det Nationale Kompetenceregnskab - Hovedrapport. København: Undervisningsministeriet. (http://pub.uvm.dk/2005/NKRresume/a.xls) 
3.2.3.2 Kortuddannede danskeres læsning og skrivning i arbejdssammenhæng - belyst ved delresultater fra Second International Adult Literacy Survey (SIALS)

I en analyse af danske delresultater fra SIALS sammenlignede Jensen, Andersen \& Halgreen (2001) oplysninger om anvendelsen af skriftligt materiale i arbejdssammenhæng blandt grupper med forskellig uddannelsesbaggrund. ${ }^{12}$ Analysen viste, at ufaglærte, som havde været i arbejde inden for det sidste år, i mindre udstrækning anvendte skriftligt materiale i deres arbejde end andre grupper. Som det fremgår af tabellen nedenfor, læste og skrev ufaglærte gennemgående ikke så ofte som personer med fx en erhvervsfaglig eller en videregående uddannelse.

Tabel 3: Læsning og skrivning på jobbet blandt personer med forskellig uddannelsesbaggrund.

\begin{tabular}{lrrr}
\hline Skal eller skulle hver dag udføre følgende opgaver på arbejdet & $\begin{array}{c}\text { Ufaglærte } \\
\text { personer }\end{array}$ & $\begin{array}{c}\text { Personer med } \\
\text { erhvervsfaglig } \\
\text { uddannelse }\end{array}$ & $\begin{array}{c}\text { Personer med } \\
\text { videregående } \\
\text { uddannelse }\end{array}$ \\
\hline $\begin{array}{l}\text { Læse eller anvende oplysninger fra breve og notater } \\
\text { Læse eller anvende oplysninger fra rapporter, artikler, } \\
\text { magasiner eller tidsskrifter }\end{array}$ & $45 \%$ & $61 \%$ & $77 \%$ \\
$\begin{array}{l}\text { Læse eller anvende oplysninger fra manualer, bruger- } \\
\text { håndbøger eller opslagsværker }\end{array}$ & $14 \%$ & $28 \%$ & $31 \%$ \\
$\begin{array}{l}\text { Læse eller anvende oplysninger fra diagrammer eller } \\
\text { skemaer }\end{array}$ & $17 \%$ & $25 \%$ & $30 \%$ \\
$\begin{array}{l}\text { Læse eller anvende oplysninger fra regninger, fakturaer, } \\
\text { regneark eller budgetskemaer }\end{array}$ & $18 \%$ & $31 \%$ & $31 \%$ \\
$\begin{array}{l}\text { Læse eller anvende oplysninger fra skriftligt materiale på et } \\
\text { andet sprog end dansk }\end{array}$ & $6 \%$ & $13 \%$ & $23 \%$ \\
\begin{tabular}{l} 
Skrive breve eller længere notater \\
\hline
\end{tabular} & $35 \%$ & $50 \%$ & $63 \%$ \\
\hline
\end{tabular}

Ifølge Jensen et al. oplyste $14 \%$ af de ufaglærte endvidere, at de aldrig læste breve og notater på arbejdet, mens 27 \% af dem læste aldrig rapporter, artikler, magasiner eller tidsskrifter. Omkring halvdelen af de ufaglærte læste aldrig tekster på en computerskærm, og halvdelen læste aldrig fremmedsproget materiale. For alle disse teksttyper gjaldt det ifølge Jensen et al., at der var omkring dobbelt så mange ufaglærte som personer med en erhvervsfaglig uddannelse, der aldrig læste den pågældende teksttype på arbejdet. I forhold til personer med videregående uddannelse var der omkring fem gange så mange ufaglærte, der ikke læste de nævnte teksttyper.

Jensen et al. gennemførte en række analyser af variationen i deltagernes brug af skriftligt materiale, hvor der samtidig blev taget højde for

\footnotetext{
${ }^{12}$ Jensen, T.P., Andersen, A. \& Halgreen, T. (2001). Lœsefærdigheder og deltagelse i samfundslivet. København: Amternes og Kommunernes Forskningsinstitut \& Specialarbejderforbundet i Danmark.

${ }^{13}$ Tabellen er udarbejdet på basis af data fra Jensen et al. (2001). Lœsefœrdigheder og deltagelse i samfundslivet (pp. 30-41). København: Amternes og Kommunernes Forskningsinstitut \& Specialarbejderforbundet i Danmark. Det bemærkes, at de angivne tal for deltagere med erhvervsfaglig og videregående uddannelse er omtrentlige, idet de i mange tilfælde ikke fremgår entydigt af rapporten, men har måttet aflæses skønsmæssigt på basis af diagrammer i rapporten.
} 
forskelle i deltagernes læsefærdigheder, uddannelsesbaggrund, erhverv og alder. Hvis man sammenlignede personer, som havde det samme læsefærdighedsniveau, men forskellig uddannelsesbaggrund, viste det sig, at personer, som var ufaglærte eller havde en erhvervsfaglig uddannelse, læste mindre end andre på arbejde. Samlet forholder det sig ifølge Jensen et al. således, at jo ringere læsefærdigheder man har, jo mindre skal man anvende skriftligt materiale på sit arbejde. Har man derudover ingen uddannelse efter grundskolen, forstærkes denne tendens. En blandt flere forklaringer på dette er ifølge Jensen et al., at de ufaglærte typisk er beskæftiget i erhverv, hvor brugen af skriftligt materiale er mindre almindelig end $i$ andre erhverv.

Af de ufaglærte personer, som havde været beskæftiget inden for de seneste 12 måneder, oplevede $17 \%$, at deres læsefærdigheder var begrænsende for deres muligheder på arbejdsmarkedet, hvilket var over dobbelt så mange som blandt personer med en erhvervsfaglig uddannelse og fem gange så mange som blandt personer med en videregående uddannelse.

3.2.3.3 Kortuddannede danskeres læsning i arbejdssammenhæng - belyst ved resultater fra spørgeskemaundersøgelse blandt kursister i arbejdsmarkedsuddannelser (AMU)

Munch-Hansen \& Albæk (1994) ${ }^{14}$ gennemførte en spørgeskemaundersøgelse blandt 136 kursister inden for forskellige arbejdsmarkedsuddannelser (forkortes på dansk normalt til AMU). Undersøgelsen viste, at over 70 \% af kursisterne jævnligt eller af og til på arbejdet havde skullet læse blandt andet opslag på opslagstavle, etiketter på beholdere, betjeningsvejledninger og sikkerhedsregler og havde skullet udfylde arbejdssedler og skrive beskeder. Langt hovedparten oplevede således, at læsning og skrivning indgik som en del af deres jobfunktion.

Endvidere blev 206 AMU-kursister spurgt, om de oplevede at have vanskeligheder med forskellige typer af hverdagstekster, fx brugsanvisninger, køreplaner og bykort. Generelt var der kun relativt få deltagere, der angav at have vanskeligheder med de forskellige teksttyper. Det var dog bemærkelsesværdigt, at det primært var kursister fra landstransportområdet (dvs. bus- og lastbilchauffører), der angav at have vanskeligheder med køreplaner. Således angav 14 \% af deltagerne fra landtransportområdet, at de oplevede vanskeligheder med læsning af køreplaner, mens dette gennemsnitligt kun gjaldt for $7 \%$ af hele gruppen. Forklaringen skal ifølge rapportens forfattere søges i det fravalg af vanskelig læsning, som mange voksne bevidst eller ubevidst foretager. Kursister fra andre brancher end landtransportområdet møder køreplaner som almindelige borgere, og de bruger dem i den udstrækning, de synes, at køreplanerne

\footnotetext{
${ }^{14}$ Munch-Hansen, T. \& Albæk, K. (1994). Faglæs - et analyse- og udviklingsprojekt om læsesvage i arbejdsmarkedsuddannelserne. København: Arbejdsmarkedsstyrelsen.
} 
hjælper dem. Og kan de ikke finde ud af det, søger de hjælp andetsteds, blandt andet ved at spørge chaufføren!

3.2.3.4 Arbejdsgiveres vurdering af medarbejderes læse- og skrivefærdigheder - belyst ved resultater fra dansk interviewundersøgelse blandt arbejdsgivere inden for Handels-, Transport- og Serviceerhvervene I 2003 blev der gennemført en telefonisk interviewundersøgelse blandt medlemmer af Handels-, Transport- og Serviceerhvervenes Arbejdsgiverforening. ${ }^{15}$ I alt deltog repræsentanter for 751 virksomheder. Undersøgelsen viste blandt andet, at $66 \%$ af de interviewede arbejdsgivere oplevede, at der var medarbejdere i deres virksomhed med læse- og/eller staveproblemer. Blandt de arbejdsgivere, der mente, at de havde medarbejdere med sådanne problemer, angav de $29 \%$, at dette medførte vanskeligheder i det daglige arbejde.

3.2.4 Undersøgelser vedrørende lasning og skrivning i uddannelses- og kursussammenhæeng

3.2.4.1. Undersøgelse af tosprogedes læse- og skrivevanskeligheder ved overgang fra sprogcenterundervisning til deltagelse i erhvervsrettede uddannelser

Lund, Bertelsen \& Sørensen (2006) har på baggrund af blandt andet observationer af undervisning og eksaminer, interviews og analyser af anvendte skriftlige materialer gennemført en undersøgelse af kravene til mundtlige og skriftsproglige færdigheder i udvalgte erhvervsuddannelser (EUD) og arbejdsmarkedsuddannelser (AMU). ${ }^{16}$ Disse krav er blevet sammenholdt med de krav, der stilles i undervisningen og ved de afsluttende prøver på sprogcentrenes Danskuddannelse 2 (DU2), som er rettet mod indvandrere med kort uddannelse fra hjemlandet. Bestået DU2 giver formelt adgang til AMU og EUD. Undersøgelsen viser, at der indgår omfattende krav til læsning og skrivning på AMU og i endnu højere grad på EUD. Med hensyn til læsning viser undersøgelsen blandt andet:

- Læsestrategien omhyggelig globallæsning, altså at kunne nærlæse og forstå en tekst med det formål at få fat i tekstens hovedindhold, er påkrævet i forhold til at læse og forstå skriftlige instruktioner til opgaver.

- Skilte og forskrifter ophængt i læringsrummet kræver skimme- og scannelæsning, altså hurtigt at kunne overse en hel tekst og finde

\footnotetext{
${ }^{15}$ Handels-, Transport- og Serviceerhvervenes Arbejdsgiverforening \& Institut for KonjunkturAnalyse (2004). Det rummelige Arbejdsmarked. Tiltrckke, fastholde, udvikle. København: Handels-, Transport- og Serviceerhvervenes Arbejdsgiverforening.

${ }^{16}$ Lund, K., Bertelsen, E. \& Sørensen, M.S. (2006). Muligheder og barrierer - en undersøgelse af overgangen mellem sprogcentre og erhvervsrettede uddannelser. København: Ministeriet for Flygtninge, Indvandrere og Integration.
} 
relevante oplysninger, med henblik på hurtigt at kunne respondere adækvat på de relevante anvisninger og instruktioner.

- Læsestrategien omhyggelig global og lokal læsning, altså at nærlæse en tekst og dele af teksten for flere betydningslag, er nødvendig at beherske i forhold til fagtekster og skønlitterære tekster.

Med hensyn til skrivning viser undersøgelsen blandt andet:

- På AMU er skrivning kun i mindre grad nødvendig og anvendes primært til besvarelse af kontrolspørgsmål og udfyldning af skemaer.

- På EUD forekommer skriftlige opgaver i flere fag, fx dansk og matematik.

- På EUD indgår den beskrivende, fortællende skriftlige fremstilling desuden i form af rapportskrivning, og i nogle uddannelser også som logbogsskrivning.

- På EUD til eksamen i dansk indgår fremlæggelse af portfolio med forskellige eksempler på skriftlige arbejder hvor eleven skal reflektere over egen skriftlighed.

Forfatterne vurderer på basis af analyser af de mundtlige og skriftlige prøver fra DU2-eksamen, at den gennemsnitlige prøvedeltagers læsefærdigheder rækker til at finde faktuelle oplysninger i en kortere informerende tekst, fx en informerende brochure hvor informationstætheden er forholdsvis lav, sproget enkelt, og temaet kendt. Færdighederne rækker også til at læse og forstå hovedindholdet af en fortællende eller beskrivende tekst, der handler om dagligdags emner, fx en kort ugebladsartikel, men ikke til at forstå indholdet af fx tekstbogen til et AMU-kursus i fødevarehygiejne eller i rengøring. Prøvedeltageren kan skriftligt genbruge formuleringer fra tekster, men kan i de fleste tilfælde ikke selv formulere passende og præcise svar eller kombinere oplysninger præsenteret flere steder i teksten. Han/hun vil altså ikke kunne opfylde kravene til fx rapportskrivning på mange erhvervsuddannelser.

Forfatterne konkluderer på baggrund af undersøgelsen, at den typiske kursist fra DU2 ikke vil have læsefærdigheder på dansk, der gør det muligt at tilegne sig det centrale faglige stof på hverken AMU eller EUD gennem læsning. Forfatterne vurderer, at for de fleste af de DU2kursister, der kommer direkte fra sprogskolen, vil videre uddannelse inden for AMU eller EUD kræve en særlig tilrettelagt undervisning i dansk som andetsprog.

3.2.4.2. Sammenhænge mellem læsefærdigheder og faglige præstationer blandt deltagere i tekniske erhvervsuddannelser og almen voksenuddannelse

Arnbak \& Elbro (1999) gennemførte en undersøgelse blandt 773 unge og voksne fra følgende fem kurser og uddannelser: tekniske erhvervsuddan- 
nelser, gymnasiet, almen voksenuddannelse, læsekurser for voksne og kurser for voksne ordblinde. ${ }^{17}$ Ved kursernes eller uddannelsernes start blev der gennemført en undersøgelse af deltagernes færdigheder i afkodning og læseforståelse af forskellige typer dagligdags tekster (opslagstekster, informerende tekster og fortællende tekster). Undersøgelsen viste blandt andet, at der blandt de 167 unge i de tekniske erhvervsuddannelser var relativt stærke sammenhænge mellem deres præstationer på læsetestene og de afsluttende karakterer i skriftsprogstunge discipliner som mundtlig og skriftlig dansk samt skriftlig engelsk. Der blev således fundet korrelationer mellem deltagernes læseresultater og karakterer i størrelsesordenen $0,42-0,54(\mathrm{p}<0,01)$.

På basis af resultaterne fra den ovenfor nævnte undersøgelse har Arnbak (2004) foretaget en nærmere analyse af sammenhængen mellem læsefærdigheder og eksamenskarakterer blandt 194 kursister i den almene voksenundervisning (AVU). ${ }^{18}$ Denne undervisning fører frem til folkeskolens afgangsniveau og retter sig mod voksne med kort skolegang. AVU-kursisternes resultater på testene af færdigheder i afkodning og læseforståelse blev sammenholdt med oplysninger om de eksamenskarakter, som kursisterne nogle måneder senere opnåede. Undersøgelsen viste, at de kursister, som lå blandt de dårligste 10 \% på læseforståelsestesten, generelt udviste tegn på afkodningsvanskeligheder og fik meget lave karakterer i skriftsprogstunge fag. Dette tolkes af forfatterne som et udtryk for, at disse kursister havde så store læsevanskeligheder, at det gav dem problemer med at opfylde kravene i de skriftsprogstunge fag i den almene voksenundervisning. Selv om der var en større spredning i eksamenskaraktererne blandt de kursister, som lå mellem 10- og 25percentilen på læseforståelsestesten, klarede også mange af disse sig dårligt i de skriftsprogstunge fag og fik som oftest karakterer under middel.

3.2.4.3. Undersøgelse af omfanget af vanskeligheder med faglig læsning blandt deltagere i arbejdsmarkedsuddannelser

Arnbak (1999) gennemførte en undersøgelse af læsefærdigheder blandt 251 deltagere i et grundkursus, som blev afholdt på forskellige arbejdsmarkedsuddannelsescentre (AMU-centre). ${ }^{19}$ Deltagernes færdigheder i at læse hverdagstekster blev afdækket med en læseforståelsestest, som tidligere var blevet afprøvet på deltagere fra andre kurser og uddannelser (jf. den ovenfor omtalte undersøgelse af Arnbak \& Elbro, 1999). Endvidere blev der gennemført en faglig læseprøve, som skulle afdække deltagernes færdigheder i at læse tekster fra den grundbog, som blev anvendt på kur-

\footnotetext{
${ }^{17}$ Arnbak, E. \& Elbro, C. (1999). Læsning, læsekurser og uddannelse. Om unge og voksnes funktionelle læsefærdighed i uddannelse og på læsekurser vurderet med et nyt materiale. København: Center for Læseforskning, Københavns Universitet.

${ }^{18}$ Arnbak, E. (2004). When are poor reading skills a threat to educational achievement? Reading and Writing: An Interdisciplinary Journal, 17, 459-482.

${ }^{19}$ Arnbak, E. (1999). Faglig læsning i AMU - en undersøgelse af sammenhængen mellem AMU-deltageres funktionelle læsefærdighed og deres faglige læsning. København: Arbejdsmarkedsstyrelsen.
} 
set. Den faglige læseprøves første del bestod af en række spørgsmål til uddrag af grundbogsteksten, mens den anden del bestod af en cloze-test, hvor deltagerne skulle indsætte manglende ord i en tekst fra grundbogen. På basis af resultaterne på den faglige læseprøve blev det vurderet, at 6 \% af deltagerne kunne karakteriseres som svage læsere, idet de havde besvaret mindre end halvdelen af opgaverne korrekt. Det blev endvidere vurderet, at $33 \%$ af deltagerne udgjorde en risikogruppe, idet de i den ene del af prøven besvarede mindre end $75 \%$ af opgaverne korrekt.

Undersøgelsen viste, at en relativt stor del af deltagerne også havde vanskeligheder med at læse og forstå hverdagstekster, og at deltagerne i gennemsnit læste på niveau med kursister på amtslige læsekurser for voksne. Der var en stærk sammenhæng mellem deltagernes færdigheder i læsning af hhv. hverdagstekster og kursusrelaterede tekster. Således klarede de deltagere, som på basis af den faglige læseprøve var blevet kategoriseret som svage læsere eller som værende i risikogruppe, sig gennemsnitligt signifikant ringere på hverdagslæseprøven end de øvrige deltagere.

3.2.4.4. Undersøgelse af omfanget af læse- og stavevanskeligheder blandt deltagere i arbejdsmarkeds- og erhvervsuddannelser

Grønborg, Madsen, Nielsen \& Sørensen (1994) gennemførte en undersøgelse af læse- og stavestandpunktet hos i alt 457 deltagere i arbejdsmarkeds- og erhvervsuddannelser. ${ }^{20} 310$ af de undersøgte deltog i arbejdsmarkedsuddannelser på AMU-skolen i Odense. Gennemsnitsalderen for denne gruppe var 32,3 år. De resterende 149 deltagere var førsteårselever på Teknisk Skole i Odense og var gennemsnitligt 19,1 år gamle. Deltagernes læsefærdighed blev testet med læseforståelsestesten S50, som er en sætningslæseprøve, hvor deltagerne i en række opgaver skal afgøre, hvilke af flere mulige billeder der bedst illustrerer en given sætning. Denne test er oprindelig udviklet til og afprøvet på børn i 2.-5. klasse. Deltagernes stavefærdighed blev testet med stavetesten ST5, som oprindelig er udviklet til skoleelever i 5. klasse. Undersøgelsen viste, at knap $40 \%$ af de undersøgte havde stavefærdigheder, der højst svarede til gennemsnittet for skoleelever midt i 5. klasse. På læsetesten scorede godt 40 $\%$ af deltagerne scorede ringere end gennemsnittet for elever i 5 . klasse. På denne baggrund vurderede forfatterne til rapporten om undersøgelsen, at godt $40 \%$ af de undersøgte havde så ringe læsefærdigheder, at det medfører store problemer i uddannelsessammenhæng på arbejdsmarkedsog erhvervsuddannelser.

\footnotetext{
${ }^{20}$ Grønborg, A. Madsen, P. Nielsen, B. \& Sørensen, H. (1994). Incidensundersøgelse. En undersøgelse af læse- og stavestandpunktet blandt elever på teknisk Skole og AMU-skolen i Odense foretaget i foråret 1994. Odense: Fyns Amts Tale- og Høreinstitut.
} 


\subsection{Norge}

\subsubsection{Sammenfatning vedrørende undersøgelser af omfanget af lcesevanskeligheder blandt kortuddannede i Norge}

Norge har i 2003 som det eneste nordiske land deltaget i den internationale OECD-undersøgelse $A L L$. Desuden har Norge i lighed med Danmark, Sverige og Finland tidligere deltaget i SIALS. Ifølge resultaterne fra både $A L L$ og SIALS befandt lidt over $60 \%$ af de undersøgte nordmænd uden nogen uddannelse ud over grundskolen sig på de to laveste færdighedsniveauer i læsning og dermed under det niveau, som ifølge OECD er nødvendigt (jf. afsnit 3.3.2.1 og 3.3.2.2).

Der er gennemført flere undersøgelser, der på forskellig vis kan belyse kortuddannede nordmænds læsning og skrivning i arbejdssammenhæeng. Det fremgår af disse undersøgelser, at ufaglærte nordmænd gennemgående læser og skriver væsentligt mindre på jobbet end personer, der har afsluttet en uddannelse efter grundskolen (jf. afsnit 3.3.3.1).

I tråd hermed har en norsk spørgeskemaundersøgelse vist, at kortuddannede ansatte i mindre grad end ansatte med længere uddannelse oplevede, at de drog nytte af skriftlige læringskilder, og at de kortuddannede oftere end andre ansatte var i en situation, hvor de primært lærte af kolleger og overordnede (jf. 3.3.3.2).

I en interviewundersøgelse gav et flertal af virksomhedsledere udtryk for, at det var vigtigt, at også ufaglærte medarbejdere havde gode færdigheder i blandt andet at læse jobrelevant information, udtrykke sig skriftligt og bruge relevant IT-værktøj (jf. 3.3.3.3). Undersøgelsen viste endvidere, at der var en tendens til, at virksomhedslederne i mindre grad var tilfredse med de ufaglærte medarbejderes læse-, skrive- og ITfærdigheder end med de tilsvarende færdigheder blandt faglærte og højtuddannede medarbejdere.

En enkelt undersøgelse kan i nogen grad belyse omfanget af læse- og skrivevanskeligheder i uddannelsessammenhæng. I en spørgeskemaundersøgelse blandt voksne i „videregående opplæring“ oplyste således 19 $\%$ af de adspurgte, at de oplevede at have sådanne vanskeligheder (jf. 3.3.4.1).

\subsubsection{Undersøgelser af kortuddannedes lase- og skriveferdigheder}

3.3.2.1 Kortuddannedes læsefærdigheder - belyst ved norske delresultater fra undersøgelsen „Adult Literacy and Life Skills“ (ALL)

Norge har som det eneste nordiske land deltaget i OECD's undersøgelse Adult Literacy and Life Skills (ALL), som er en opfølgning af (Second) International Adult Literacy Survey (SIALS). Den norske del af $A L L$ blev gennemført i 2003 og involverede over 7000 repræsentativt udvalgte personer mellem 16 og 65 år. Gabrielsen, Haslund \& Lagerstrøm (2005) 
har analyseret og rapporteret de norske resultater fra denne undersøgelse. ${ }^{21}$ Gabrielsen har endvidere i en nyligt publiceret monografi redegjort for teorigrundlaget for læseskalaerne i såvel $A L L$ som (S)IALS. ${ }^{22}$

Af de to nedenstående tabeller fremgår det, at omkring en fjerdedel af de norske deltagere i $A L L$, som ikke har nogen eksamen ud over grundskolen, har læsefærdigheder på niveau 1, uanset om der tages udgangspunkt i prosatekster eller dokumenttekster. Denne andel er markant højere end den tilsvarende andel af personer med en uddannelse ud over grundskolen. Også på niveau 2 er gruppen uden uddannelse stærkt overrepræsenteret, idet mellem 36 og 39 \% af denne gruppe befinder sig på dette niveau. Da OECD har fastsat niveau 3 som et minimumskriterium for funktionelle læsefærdigheder, vil det sige, at sammenlagt over $60 \%$ af personerne uden uddannelse ud over grundskolen har et læsefærdighedsniveau, som af OECD anses som værende utilstrækkeligt. Til sammenligning befandt omkring en tredjedel af hele den norske deltagergruppe sig på de to laveste niveauer målt med de to læsetest.

Tabel 4: Læsning af prosatekster („prose literacy“) blandt norske deltagere i $A L L^{23}$

\begin{tabular}{lrrrr}
\hline Uddannelsesniveau & $\begin{array}{r}\text { Niveau 1 } \\
\text { \% }\end{array}$ & $\begin{array}{r}\text { Niveau 2 } \\
\text { \% }\end{array}$ & $\begin{array}{r}\text { Niveau 3 } \\
\text { \% }\end{array}$ & $\begin{array}{r}\text { Niveau 4/5 } \\
\%\end{array}$ \\
\hline Max. 9 års grundskole & 23,5 & 38,9 & 31,4 & 6,2 \\
$\begin{array}{l}\text { Eksamen fra „videregående skole“ (almen eller } \\
\text { erhvervsfaglig) }\end{array}$ & 5,4 & 28,3 & 49,5 & 16,8 \\
$\begin{array}{l}\text { Eksamen på højere uddannelsesniveau } \\
\text { (,høgskole“ eller universitet) }\end{array}$ & 2,3 & 12,4 & 47,5 & 37,9 \\
Alle deltagere i den norske del af $A L L$ & 7,9 & 26,2 & 45,3 & 20,6 \\
\hline
\end{tabular}

Tabel 5: Læsning af dokumenttekster („document literacy“) blandt norske deltagere i $A L L^{24}$

\begin{tabular}{lrrrr}
\hline Uddannelsesniveau & $\begin{array}{r}\text { Niveau 1 } \\
\text { \% }\end{array}$ & $\begin{array}{r}\text { Niveau 2 } \\
\text { \% }\end{array}$ & $\begin{array}{r}\text { Niveau 3 } \\
\%\end{array}$ & $\begin{array}{r}\text { Niveau 4/5 } \\
\%\end{array}$ \\
\hline Max. 9 års grundskole & 26,7 & 36,7 & 27,0 & 9,6 \\
$\begin{array}{l}\text { Eksamen fra „videregående skole“ (almen eller } \\
\text { erhvervsfaglig) }\end{array}$ & 6,8 & 25,7 & 43,0 & 24,5 \\
$\begin{array}{l}\text { Eksamen på højere uddannelsesniveau } \\
\text { (,høgskole“ eller universitet) }\end{array}$ & 2,7 & 12,5 & 38,4 & 46,4 \\
Alle deltagere i den norske del af $A L L$ & 8,9 & 23,5 & 39,7 & 27,9 \\
\hline
\end{tabular}

\footnotetext{
${ }^{21}$ Gabrielsen, E., Haslund, J. \& Lagerstrøm, B.O. (2005). Lese- og mestringskompetanse i den norske voksenbefolkningen. Resultater fra „Adult Literacy and Life Skills“ (ALL). Stavanger: Universitetet i Stavanger, Lesesenteret.

${ }^{22}$ Gabrielsen, E. (2006). Slik kan voksnes leseferdigheter måles. Om teorigrunnlaget for IALS og ALL. Monografiserien ALL nr. 6. Stavanger: Universitetet i Stavanger, Lesesenteret.

${ }^{23}$ Tabellen er udarbejdet på basis af data fra: Gabrielsen, E., Haslund, J. \& Lagerstrøm, B.O. (2005). Lese- og mestringskompetanse i den norske voksenbefolkningen. Resultater fra „Adult Literacy and Life Skills“ (ALL). (pp. 52+185). Stavanger: Universitetet i Stavanger, Lesesenteret.

${ }^{24}$ Tabellen er udarbejdet på basis af data fra: Gabrielsen, E., Haslund, J. \& Lagerstrøm, B.O. (2005). Lese- og mestringskompetanse i den norske voksenbefolkningen. Resultater fra „Adult Literacy and Life Skills“ (ALL). (pp. 52+185). Stavanger: Universitetet i Stavanger, Lesesenteret.
} 
Den norske del af $A L L$-undersøgelsen viste endvidere, at i de fleste erhverv, som i perioden 1985-2002 har haft nedgang eller kun ubetydelig øgning i antallet af beskæftigede (fx jordbrug og fiskeri samt bygge- og anlægsområdet) ligger resultaterne på læseopgaverne væsentligt under gennemsnittet for den voksne befolkning. I modsætning hertil har de erhverv, som i perioden 1985-2002 har haft en stigning i antallet af beskæftigede (fx områder som bank, finans og forsikring), gennemgående højere gennemsnitsscores end befolkningen som helhed. ${ }^{25}$

3.3.2.2 Omfanget af læsevanskeligheder blandt voksne nordmænd med særligt fokus på ufaglærte - belyst ved delresultater fra Second International Adult Literacy Survey (SIALS)

Omkring 5300 personer mellem 16 og 65 år deltog i den norske del af SIALS, som blev gennemført i 1998. Gabrielsen (2000) har analyseret og rapporteret de norske resultater fra SIALS. ${ }^{26}$ På en test af lessning af fortløbende tekster som avisartikler og brochurer (,prose literacy“) opnåede $8,5 \%$ af de norske deltagere resultater, der svarer til niveau 1, dvs. det laveste af OECD's fem niveauer, mens $24,7 \%$ af deltagerne befandt sig på niveau 2. Således klarede i alt 33,2 \% af de norske deltagere sig så ringe på testen af læsning af fortløbende tekster, at de lå under niveau 3, som af OECD er fastsat som minimumskriterium. På en test af forståelse af dokumenttekster som fx tidstabeller, diagrammer, kort og blanketter („,document literacy“) præsterede i alt 29,6 \% af de norske deltagere under OECD’s minimumskriterium, idet 8,6 \% befandt sig på niveau 1 og $21 \%$ på niveau 2.

På basis af de to læsetest kunne således omkring en tredjedel af nordmændene kategoriseres som havende utilstrækkelige læsefærdigheder ifølge det minimumskriterium, som OECD har fastsat. Det kan dog bemærkes, at blandt andre lederne af hhv. den norske og den svenske del af (S)IALS har argumenteret for, at man i stedet afgrænser risikogruppen til dem, som på en eller flere af de tre anvendte test i SIALS opnår resultater, der svarer til niveau $1 .^{27}$ Hvis man anvender denne mere forsigtige afgrænsning i stedet for OECD’s afgrænsning, medfører det, at „kun“ cirka $12 \%$ af den norske befolkning mellem 16 og 65 år, svarende til cirka 350.000 personer, anses for at udgøre en risikogruppe i forhold til at leve op til hverdagens læsekrav. ${ }^{28}$

Som det fremgår af den nedenstående tabel, var personer uden nogen uddannelse ud over grundskolen stærkt overrepræsenterede blandt de

\footnotetext{
${ }^{25}$ Gabrielsen, Haslund \& Lagerstrøm (2005). Lese- og mestringskompetance i den norske voksenbefolkningen. Resultater fra „Adult Literacy and Life Skills (ALL), s. 93-95.

${ }^{26}$ Gabrielsen, E. (2000). Slik leser voksne i Norge. En kartlegging av leseferdigheten i aldersgruppen 16-65 år. Stavanger: Senter for læseforsking.

${ }^{27}$ Gabrielsen, E., \& Myrberg, M. (2001). Adult education for at-risk groups. In: Tuijnman, A. \& Hellström, Z. (eds.). Curious Minds. Nordic Adult Education Compared (pp. 105-115). København: Nordisk Ministerråd.

${ }^{28}$ Gabrielsen, E. (2005). Hvor godt må vi kunne lese for å fungere i dagens samfunn? Samfunnsspeilet 2. (http://www.ssb.no/ssp/)
} 
deltagere, der placerede sig på de laveste niveauer. Således placerede sammenlagt over $60 \%$ af personerne sig uden nogen uddannelse ud over grundskolen på disse to niveauer.

Tabel 6: Resultater i læsning af prosatekster (prose literacy) blandt norske deltagere $i$ SIALS ${ }^{29}$

\begin{tabular}{|c|c|c|c|c|}
\hline Uddannelsesniveau & $\begin{array}{r}\text { Niveau } 1 \\
\%\end{array}$ & $\begin{array}{r}\text { Niveau } 2 \\
\%\end{array}$ & $\begin{array}{r}\text { Niveau } 3 \\
\%\end{array}$ & $\begin{array}{r}\text { Niveau } 4 / 5 \\
\%\end{array}$ \\
\hline Ingen uddannelse ud over grundskolen & $24,8 \%$ & $37,3 \%$ & $31,9 \%$ & $6,0 \%$ \\
\hline $\begin{array}{l}\text { Eksamen fra „videregående skole“ (almen eller } \\
\text { erhvervsfaglig) }\end{array}$ & $7,9 \%$ & $28,7 \%$ & $50,6 \%$ & $12,8 \%$ \\
\hline $\begin{array}{l}\text { Eksamen efter mere end tre års studier på } \\
\text { højere uddannelsesniveau („,høgskole“ eller } \\
\text { universitet) }\end{array}$ & $1,0 \%$ & $6,1 \%$ & $50,2 \%$ & $42,6 \%$ \\
\hline Alle deltagere i den norske del af SIALS & $8,5 \%$ & $24,7 \%$ & $49,2 \%$ & $17,6 \%$ \\
\hline
\end{tabular}

\subsubsection{Undersøgelser vedrørende læesning og skrivning $i$} arbejdssammenhoeng

3.3.3.1 Kortuddannedes brug af læsning og skrivning i arbejdssammenhæng - belyst ved norske delresultater fra Second International Adult Literacy Survey (SIALS)

I en analyse af de norske resultater fra SIALS fandt Gabrielsen (2000), at ufaglærte, som havde været i arbejde inden for det sidste år, generelt læste og skrev væsentligt mindre på jobbet end andre grupper, herunder

Tabel 7: Brug af læsning og skrivning på arbejdet blandt norske SIALS-deltagere 30

\begin{tabular}{lccc}
\hline $\begin{array}{l}\text { Arbejder mindst én gang om ugen på jobbet med } \\
\text { følgende opgave }\end{array}$ & Ufaglærte & $\begin{array}{r}\text { Faglærte } \\
\text { håndværke- } \\
\text { re }\end{array}$ & $\begin{array}{r}\text { Akademike- } \\
\text { re }\end{array}$ \\
\hline Læser brev eller længere notat & $27 \%$ & $54 \%$ & $96 \%$ \\
Læser rapporter eller artikler & $16 \%$ & $51 \%$ & $91 \%$ \\
Læser manualer, håndbøger eller kataloger & $17 \%$ & $46 \%$ & $59 \%$ \\
Læser diagrammer eller skemaer & $13 \%$ & $42 \%$ & $65 \%$ \\
Læser regninger, fakturaer eller budgetter & $13 \%$ & $19 \%$ & $38 \%$ \\
Læser skriftlig information på andet sprog end norsk & $13 \%$ & $21 \%$ & $38 \%$ \\
Læser vejledninger eller instruktioner & $4 \%$ & $4 \%$ & $49 \%$ \\
Skriver brev eller længere notat & $10 \%$ & $23 \%$ & $80 \%$ \\
Skriver formularer, regninger, fakturaer & $7 \%$ & $16 \%$ & $25 \%$ \\
eller budget & & & $39 \%$ \\
Skriver rapporter eller artikler & $6 \%$ & $14 \%$ & $20 \%$ \\
Skriver tekniske vurderinger eller specifikationer & $4 \%$ & $21 \%$ &
\end{tabular}

${ }^{29}$ Tabellen er udarbejdet på basis af data fra: Gabrielsen, E. (2000). Slik leser voksne i Norge. En kartlegging av leseferdigheten i aldersgruppen 16-65 år (pp. 49+126). Stavanger: Senter for læseforsking.

${ }^{30}$ Tabellen er udarbejdet på basis af data fra Gabrielsen, E. (2000). Slik leser voksne i Norge. En kartlegging av leseferdigheten i aldersgruppen 16-65 år (pp. 77-78). Stavanger: Senter for læseforskning. 
faglærte håndværkere og akademikere. Som tabel 7 viser, var det fx kun $27 \%$ af de ufaglærte, der mindst én gang om ugen læste et brev eller længere notat på jobbet, sammenlignet med $54 \%$ af de faglærte håndværkere og $96 \%$ af akademikerne. ${ }^{31}$

3.3.3.2 Kortuddannedes nordmænds brug af læsning som kilde til læring i arbejdssammenhæng - belyst ved resultater fra spørgeskemaundersøgelse Nyen (2005) har for Forskningsstiftelsen Fafo gennemført en spørgeskemaundersøgelse til belysning af, hvordan forskellige grupper af voksne lærer i arbejdssammenhæng. ${ }^{32}$ Undersøgelsen er foretaget blandt et stort repræsentativt udvalg af personer i alderen 22-66 år som en tillægsundersøgelse til en af Statistisk Sentralbyrås årlige arbejdskraftundersøgelser. Antallet af personer, der har deltaget i spørgsmålene om læring, varierer ifølge Nyen mellem 8.000 og 18.000. Undersøgelsen viste, at kortuddannede ansatte i mindre grad end ansatte med længere uddannelse drager nytte af skriftlige læringskilder og oftere end andre ansatte er i en situation, hvor de primært lærer af kolleger og overordnede. Således oplyste kun $28 \%$ af de adspurgte uden nogen uddannelse ud over grundskolen, at de lærte noget, som de havde nytte af på jobbet, ved at hente skriftlig information på internet, i faglitteratur, i håndbøger og lignende. Til sammenligning oplyste cirka $54 \%$ af de adspurgte med „videregående opplæring“ og hele $85 \%$ af de adspurgte med lang højere uddannelse, at de ved hjælp af skriftlig information lærte noget, som de havde nytte af på jobbet. Cirka $72 \%$ af de kortuddannede deltagere i undersøgelsen oplyste, at de lærte noget, de havde nytte af på jobbet, ved at arbejde sammen med dygtige kolleger, og cirka $43 \%$ af de kortuddannede lærte noget nyttigt gennem tilbagemelding fra overordnede. På disse sidste to punkter adskilte de kortuddannede sig ikke markant fra voksne med „videregående opplæring“.

3.3.3.3 Virksomhedslederes vurdering af kortuddannedes færdigheder i læsning, skrivning og IT - belyst ved resultater fra norsk interviewundersøgelse

Vox, det nationale center for læring i arbejdslivet, har gennemført en undersøgelse af norske virksomhedslederes holdninger til og erfaringer med medarbejdernes grundlæggende færdigheder. ${ }^{33}$ Undersøgelsen er baseret på interviews med 1500 virksomhedsledere, som er udvalgt repræsentativt i forhold til brancher, erhverv og antallet af ansatte. De blev blandt andet spurgt om, hvorvidt det var vigtigt, at virksomhedens medarbejdere havde gode færdigheder inden for læsning, skrivning og IT.

\footnotetext{
${ }^{31}$ Gabrielsen, E. (2000). Slik leser voksne i Norge. En kartlegging av leseferdigheten i aldersgruppen 16-65 år. Stavanger: Senter for læseforskning.

${ }^{32}$ Nyen, T. (2005). Livslang læring i norsk arbeidsliv II. Resultater fra Lærevilkårsmonitoren 2005. Oslo: Forskningsstiftelsen Fafo.

${ }^{33}$ Bekkevold, K., Yin, H., Servan, K.T., Jørgensen P.M. \& Anderssen, A.F. (2005). Grundleggende ferdigheter i norsk arbeidsliv. Resultater fra Vox-barometeret høsten 2005. Oslo: Vox.
} 
Lederne blev også spurgt om, hvorvidt de var tilfredse med medarbejdernes færdigheder inden for disse områder. Virksomhedslederne besvarede spørgsmålene om vigtigheden af og tilfredsheden med færdighederne for hver af de følgende tre grupper:

- medarbejdere med uddannelse på „høyskole“/universitetsniveau (i det følgende benævnt „højtuddannede“)

- medarbejdere med „videregående skole“/,fagbrev“ (i det følgende benævnt „faglærte“)

- medarbejdere med grundskole som højeste uddannelse (i det følgende benævnt „kortuddannede“).

Undersøgelsen viste, at de fleste virksomhedsledere mente, at det var vigtigt, at medarbejderne havde gode færdigheder i blandt andet at læse jobrelevant information, at udtrykke sig skriftligt og at bruge relevant ITværktøj. Dette gjaldt især for de højtuddannede og faglærte medarbejdere, men også i betydelig grad for de kortuddannede. Der var en tendens til, at virksomhedslederne i mindre grad var tilfredse med de kortuddannede medarbejderes læse-, skrive- og IT-færdigheder end med de tilsvarende færdigheder blandt faglærte og højtuddannede medarbejdere. Således mente $73 \%$ af virksomhedslederne, at det var vigtigt, at kortudannede medarbejdere havde gode færdigheder i at læse jobrelevant information, mens kun $52 \%$ af virksomhedslederne var tilfredse med disse medarbejderes færdigheder på dette område. Til sammenligning mente $84 \%$ af virksomhedslederne, at det var vigtigt, at de faglærte havde gode læsefærdigheder, og $74 \%$ af lederne var tilfredse med de faglærtes læsefærdigheder (jf. tabellen nedenfor).

Tabel 8: Norske virksomhedslederes vurdering af færdighederne inden for læsning, skrivning og IT blandt hhv. kortuddannede, faglærte og højtuddannede medarbejdere. $^{34}$

\begin{tabular}{|c|c|c|c|}
\hline & Kortuddannede & Faglærte & Højtuddannede \\
\hline \multicolumn{4}{|c|}{$\begin{array}{l}\text { Virksomhedsledernes vurdering af medar- } \\
\text { bejdernes færdigheder i at læse jobrelevant } \\
\text { information }\end{array}$} \\
\hline Vigtighed & $73 \%$ & $84 \%$ & $90 \%$ \\
\hline Tilfredshed & $52 \%$ & $74 \%$ & $88 \%$ \\
\hline \multicolumn{4}{|c|}{$\begin{array}{l}\text { Virksomhedsledernes vurdering af medar- } \\
\text { bejdernes færdigheder i at udtrykke sig } \\
\text { skriftligt }\end{array}$} \\
\hline Vigtighed & $52 \%$ & $70 \%$ & $87 \%$ \\
\hline Tilfredshed & $45 \%$ & $69 \%$ & $85 \%$ \\
\hline \multicolumn{4}{|c|}{$\begin{array}{l}\text { Virksomhedsledernes vurdering af medar- } \\
\text { bejdernes færdigheder i at bruge relevante } \\
\text { IT-redskaber }\end{array}$} \\
\hline Vigtighed & $54 \%$ & $72 \%$ & $88 \%$ \\
\hline Tilfredshed & $38 \%$ & $57 \%$ & $80 \%$ \\
\hline
\end{tabular}

${ }^{34}$ Tabellen er udarbejdet på basis af data fra: Bekkevold, K., Yin, H., Servan, K. T. A., Jørgensen, P.M. \& Anderssen, A.F. (2005). Grundleggende ferdigheter i norsk arbeidsliv. Resultater fra Vox-barometeret høsten 2005 (pp. 16-19). Oslo: Vox. 
3.3.4 Undersøgelser vedrørende laesning og skrivning i uddannelses- og kursussammenhæeng

3.3.4.1 Omfanget af oplevede læse- og skrivevanskeligheder blandt voksne i „videregående opplæring“ - belyst ved resultater fra en norsk spørgeskemaundersøgelse

Læringscentret Vox gennemførte en spørgeskemaundersøgelse med 725 repræsentativt udvalgte voksne, som i foråret 2003 var meldt til eksamen i „,videregående opplæring“.${ }^{35} 87 \%$ af de adspurgte angav, at de sigtede mod at få studiekompetence, fagbrev, svendebrev eller en anden form for erhvervskompetence. $19 \%$ af de adspurgte oplyste, at de havde læse- og skrivevanskeligheder. Undersøgelsen afdækkede ikke deltagernes faktiske læse- og skrivefærdigheder ved hjælp af test. Rapporten indeholder ingen informationer om fordelingen af voksne med læse- og skrivevanskeligheder i forhold til de forskellige typer af „videregående opplæring“.

\subsection{Island}

\subsubsection{Sammenfatning vedrørende undersøgelser af omfanget af lasevanskeligheder i Island}

Island har i modsætning til de fire øvrige nordiske lande ikke deltaget i OECD’s undersøgelse (S)IALS. Så vidt det vides, foreligger der ingen data, der direkte kan belyse spørgsmålet om omfanget af læsevanskeligheder blandt voksne i Island. Imidlertid har en nyligt gennemført undersøgelse blandt voksne på en række arbejdspladser påvist en stærk sammenhæng mellem uddannelsesniveau og læsefærdigheder, idet langt flere kortuddannede viste tegn på læsevanskeligheder end personer, som havde afsluttet en uddannelse ud over grundskolen (jf. afsnit 3.4.2.1).

Der er i Island gennemført flere forespørgsler vedrørende forekomsten af deltagere med læsevanskeligheder inden for den „videregående skole“ (islandsk: framhaldsskóli). En forespørgsel i skoleåret 2005/2006 viste, at cirka $10,7 \%$ af eleverne havde fået diagnosticeret læsevanskeligheder af en eller anden type, oftest ordblindhed/dysleksi (jf. afsnit 3.4.4.1). En tidligere spørgeskemaundersøgelse fra skoleåret 2000/2001 viste, at cirka $6 \%$ af elever i den „videregående skole“ havde diagnosen ordblindhed/dysleksi (jf. 3.4.4.2).

\footnotetext{
${ }^{35}$ Engesbak, H. \& Stubbe, T.A. (2005). I videregående som voksen. Voksnes rett til grunnskole og videregående opplæring (pp. 38-40). Oslo: Vox.
} 


\subsubsection{Undersøgelser af kortuddannedes lase- og skrivefcerdigheder}

Flere islandske undersøgelser viser, at omkring $40 \%$ af de voksne, som er i arbejde, er kortuddannede. ${ }^{36}{ }^{37}$ Dette er en relativt høj andel sammenlignet med de øvrige lande i Norden. ${ }^{38}$

Imidlertid er der ikke gennemført undersøgelser af forekomsten af læsevanskeligheder blandt et repræsentativt udsnit af de kortuddannede i Island. ${ }^{39}$

Der er heller ikke gennemført undersøgelser af forekomsten af læsevanskeligheder i et repræsentativt udsnit af den islandske voksenbefolkning som helhed. Island har i modsætning til de fire øvrige nordiske lande ikke deltaget i OECD’s undersøgelse (S)IALS. Det er på Altinget i 20002001 vedtaget at gennemføre en islandsk undersøgelse af læsning og læsefærdighed hos aldersgruppen 16-65 år, men denne undersøgelse er endnu ikke igangsat. ${ }^{40}$ Så vidt det vides, foreligger der ingen data, der direkte kan belyse spørgsmålet om omfanget af læsevanskeligheder blandt voksne i Island.

Der er imidlertid gennemført en mindre undersøgelse af voksne i arbejde, hvis resultater har relevans i forhold til det aktuelle forprojekt. Denne undersøgelse rapporteres nedenfor.

3.4.2.1 Undersøgelse af sammenhæng mellem uddannelsesniveau og læsefærdigheder blandt voksne i arbejdslivet

Arnardóttir \& Kristmundsson (2005) har gennemført en undersøgelse, der blandt andet belyser sammenhængen mellem uddannelsesniveau og læsefærdigheder i en udvalgt gruppe voksne. ${ }^{41}$ Undersøgelsen blev foretaget på fire store arbejdspladser og omfattede 321 personer i aldersgruppen 17-70 år, som alle blev testet med en oversat og revideret udgave af læseprøven Reading Comprehension Battery for Aphasia (RCBA) og interviewet. 43,9 \% af deltagerne var kortuddannede, 39,6 \% havde afsluttet „videregående skole“, og 16,5 \% havde en højere uddannelse. Undersøgelsen viste, at de kortuddannede var overrepræsenterede blandt de dårlige læsere. Således befandt $15 \%$ af de deltagere, som ikke havde nogen uddannelse ud over grundskolen, sig blandt de $10 \%$, som klarede sig dårligst på læsetesten. Til sammenligning gjaldt dette for 8 \% af dem,

\footnotetext{
${ }^{36}$ Óskarsdóttir, G. G. (2000). The Transfer from School to Work. Studies on the Relationship between School and Employment. Reykjavík: University of Iceland, Social Science Institute. University of Iceland Press.

${ }^{37}$ Jónasson, J.T. \& Blöndal, K.S. (2002). Progress and completion of students in upper secondary school in Iceland in light of their residence. A study of the cohort born in 1975. Reykjavík: University of Iceland, Social Science Institute.

${ }^{38}$ Fræðslumiðstöð atvinnulífsins (2003). http://www.frae.is//files/\{1b2b75a0-443e-4169-b11c319bf485f195\} opnun\%20fa.pps

${ }^{39}$ Lund, R. (2006). Innsamling av nasjonale opplysninger i Island i forbindelse med nordisk førprosjekt om kortutdannede voksnes lesning. Reykjavik: Lestrarsetur Rannveigar Lund.

${ }^{40}$ Lund, R. (2006). Innsamling av nasjonale opplysninger i Island i forbindelse med nordisk førprosjekt om kortutdannede voksnes lesning. Reykjavik: Lestrarsetur Rannveigar Lund.

${ }^{41}$ Arnardóttir, E. \& Kristmundsson, G.B. (2005). Um niðurstöður lestrarrannsóknar. [“Om resultater fra læseforskning“]. Gátt - the annual review. Sími: Fræðslumiðstöð Atvinnulífsins.
} 
som havde afsluttet en gymnasial eller erhvervsfaglig uddannelse. Ingen blandt de $10 \%$ ringeste læsere havde en højere uddannelse som fx en universitetsuddannelse. ${ }^{42}$

\subsubsection{Undersøgelser vedrørende læesning og skrivning i arbejdssammenhweng}

3.4.3.1 Undersøgelse af læse- og skrivevaner blandt voksne i arbejdslivet Arnardóttir \& Kristmundssons ovenfor omtalte undersøgelse blandt 321 personer fra fire store arbejdspladser belyste blandt andet deltagernes læsning i arbejdssammenhæng. Undersøgelsen viste, at kun $9 \%$ af de kortuddannede oplyste, at de hver dag skulle bruge læsning som led i deres arbejde, mens dette til sammenligning gjaldt for $40 \%$ af de højtuddannede. $^{43}$

\subsubsection{Undersøgelser vedrørende leesning og skrivning i uddannelsessammenhœing}

3.4.4.1 Forespørgsel vedrørende antallet af elever med ordblindhed inden for den „videregående skole“ (framhaldsskóli) i skoleåret 2005/2006

Den „videregående skole“ (islandsk: framhaldsskóli) indeholder en boglig linje, en erhvervsfaglig linje og desuden en almen linje for personer, der ikke opfylder betingelserne for optagelse på en af de øvrige linjer. Inden for denne skoleform findes daghold for unge i alderen 16-20 år samt særlige aftenhold for voksne (islandsk: öldungadeildir).

I forbindelse med det nordiske forprojekt foretog Rannveig Lund en forespørgsel blandt konsulenter inden for den „videregående skole“ (framhaldsskóli). ${ }^{44}$ Skolekonsulenter fra 18 videregående skoler blev spurgt om antallet af elever i hver skole og antallet af elever med diagnosticeret ordblindhed (dysleksi). Tolv af disse skoler ligger i Reykjavik og omegn og de resterende seks i landområder. Fire af skolerne havde kun boglige linjer. Forespørgslen viste, at de 18 skoler tilsammen havde 15.115 elever. I alt var det 1.618 elever, som fik hjælp på grund af diagnosticerede læsevanskeligheder, oftest under termen dysleksi (ordblindhed). Der blev dog også i nogle tilfælde anvendt andre betegnelser som „specielle læsevanskeligheder“, „læseblindhed“ og „langsom læsning“. I skoleåret 2005-2006 var der således cirka 10,7 \% af eleverne, som havde fået diagnosticeret læsevanskeligheder af en eller anden slags.

\footnotetext{
${ }^{42}$ Arnardóttir, E, Kristmundsson, G.B., Björnsdóttir, A. (2006). Lœsi fullorðinna, lesiðni og ritvenjur. [Literacy among adults, time used into reading and reading habits]. Reykjavík: Rannsóknarstofnun Kennaraháskóla Íslands.

${ }^{43}$ Personlig meddelelse fra G.B. Kristmundsson i mail-korrespondance den 8. januar 2007.

${ }^{44}$ Lund, R. (2006). Innsamling av nasjonelle opplysninger i Island i forbindelse med nordisk førprojekt om kortutdannede voksnes lesning. Reykjavik: Lestrarsetur Rannveigar Lund.
} 
Gennem forespørgslen kom det endvidere frem, at der på de skoler, som kun havde boglige linjer, var færre elever med diagnosticeret ordblindhed/dysleksi end i de øvrige skoler. Således havde kun cirka 4-6 \% af eleverne i skolerne med udelukkende boglige linjer denne diagnose. Konsulentene ved de videregående skoler i landområderne med blandede studielinjer mente, at mindst $10 \%$ af elevene var ordblinde/dyslektikere. I en af skolerne i Reykjavik var $18 \%$ af eleverne diagnosticerede som ordblinde/dyslektikere, men dette er en skole, som er kendt for at tage sig godt af elever med læsevanskeligheder. Sandsynligvis kan det store antal af ordblinde elever på denne skole forklares ud fra skolens arbejde på dette område. Der er således blevet udarbejdet et program for ordblinde elever, som andre skoler har efterlignet (jf. beskrivelse af dette program i afsnit 4.3.3.2).

3.4.4.2 Spørgeskemaundersøgelse vedrørende antallet af elever med ordblindhed inden for den „videregående skole“ (framhaldsskóli) i skoleåret 2000/2001

I skoleåret 2000-2001 gennemførte Eggertsdóttir \& Jónsdóttir en spørgeskemaundersøgelse blandt 23 „,videregående skoler“. ${ }^{45}$ Spørgeskemaerne blev sendt til skolernes rektorer, som sendte dem videre til andre, oftest til skolekonsulenter. De 23 skoler havde i alt 13.137 elever, fordelt på alle linjer. Undersøgelsen viste, at cirka $6 \%$ af eleverne i den „videregående skole“ havde diagnosen ordblindhed/dysleksi. Omkring halvdelen af disse elever havde fået stillet diagnosen i grundskolen.

\subsection{Finland}

\subsubsection{Sammenfatning vedrørende undersøgelser af omfanget af} lasevanskeligheder blandt kortuddannede i Finland

I OECD’s undersøgelse Second International Adult Literacy Survey (SIALS) blev der indsamlet data fra Finland i 1998 (jf. afsnit 3.5.2.1). Kortuddannede var stærkt overrepræsenterede blandt de dårlige læsere i den finske del af SIALS. Således placerede over halvdelen af de deltagere, der ikke havde nogen uddannelse ud over grundskolen, sig under det kompetenceniveau, som ifølge OECD er nødvendigt for at kunne „bruge trykt og skreven information med henblik på at fungere i samfundet, opnå sine mål, udvikle sin viden og sit potentiale og deltage i samfundet“. Til sammenligning befandt lidt over en tredjedel af de undersøgte finner sig som helhed under dette niveau.

\footnotetext{
${ }^{45}$ Eggertsdóttir, R. og Jónsdóttir, P.B. (2001). Аðstoð við nemendur með leshömlun. Könnun í framhaldsskólum og háskólum veturinn 2000-2001. ["Hjælp til ordblinde elever. Undersøgelse inden for videregående skole og universitet, 2000-2001“]. Akureyri: Universitetet i Akureyri.
} 
Der er gennemført flere finske undersøgelser i uddannelsessammenhæng. En undersøgelse af voksne deltagere i forskellige kurser og uddannelser viste, at over $20 \%$ af dem havde vanskeligheder med at løse opgaver, hvor der skulle drages følgeslutninger på basis af informationer i de anvendte tekster (jf. 3.5.4.1). Undersøgelsen viste endvidere, at de deltagere, som kun havde gennemført grundskolen, generelt klarede sig dårligere på de anvendte test end deltagere, som havde en uddannelse ud over grundskolen. En anden undersøgelse foretaget på social- og sundhedsuddannelser viste, at 11-16 \% af deltagerne opnåede resultater på en test af læseforståelse, som lå under normen for 6. klasse (jf. 3.5.4.2). På basis af en tredje undersøgelse vurderedes det, at over $40 \%$ af deltagerne inden for bestemte erhvervsuddannelser havde svage læse- og stavefærdigheder (jf. 3.5.4.4).

\subsubsection{Undersøgelser af kortuddannedes lase- og skrivefcerdigheder}

3.5.2.1 Omfanget af læsevanskeligheder blandt voksne finner med særligt fokus på kortuddannede - belyst ved delresultater fra Second International Adult Literacy Survey (SIALS)

\section{A. Omfanget af lesevanskeligheder i den voksne befolkning som helhed}

Finland deltog i 1998 i OECD-undersøgelsen Second International Adult Literacy Survey (SIALS). Linnakylä, Malin, Blomqvist \& Julkunen (2000) har analyseret og rapporteret de finske resultater fra SIALS. ${ }^{46}$ På en test af læsning af fortløbende tekster som avisartikler og brochurer (,prose literacy“) opnåede $10 \%$ af de finske deltagere resultater, der svarer til niveau 1, dvs. det laveste af OECD's fem niveauer, mens $26 \%$ af deltagerne befandt sig på niveau 2. Således placerede i alt omkring 36 $\%$ af de finske deltagere sig på testen af læsning af fortløbende tekster under niveau 3, som af OECD er fastsat som minimumskriterium. På en test af forståelse af dokumenttekster som fx tidstabeller, diagrammer, kort og blanketter („document literacy“) præsterede i alt omkring $37 \%$ af de finske deltagere under OECD's minimumskriterium, idet $13 \%$ befandt sig på niveau 1 og $24 \%$ på niveau 2. På basis af de to læsetest kunne således lidt over en tredjedel af finnerne kategoriseres som havende utilstrækkelige læsefærdigheder ifølge det minimumskriterium, som OECD har fastsat.

\section{B. Omfanget af lcesevanskeligheder blandt kortuddannede}

Som det fremgår af de to nedenstående tabeller, var personer uden nogen uddannelse ud over grundskolen stærkt overrepræsenterede blandt de deltagere, der placerede sig på de to laveste niveauer. Dette gjaldt især for

\footnotetext{
${ }^{46}$ Linnakylä, P., Malin, A., Blomqvist, I. \& Julkunen, S. (2000). Lukutaito työssä ja arjessa: Aikuisten kansainvälinen lukutaitotutkimus Suomessa. [„Literacy in work and life: adults international literacy research in Finland“]. Jyväskylä: University of Jyväskylä, Koulutuksen tutkimuslaitos.
} 
personer med maksimalt 6 års skolegang. Således placerede $93 \%$ af denne gruppe placerede sig på niveau 1 eller 2 på testen af læsning af prosatekster, mens 91 \% placerede sig på disse niveauer på testen af læsning af dokumenttekster. Blandt personer med 7-9 års skolegang bag sig lå sammenlagt $51 \%$ på de to laveste niveauer på testen af læsning af prosatekster. På testen af læsning af dokumenttekster var det tilsvarende tal for denne gruppe $53 \%$. Disse tal er væsentligt højere end for den samlede deltagergruppe, hvor omkring 36 \% som nævnt befandt sig på de to laveste niveauer.

\begin{tabular}{|c|c|c|c|c|}
\hline Uddannelsesniveau & Niveau 1 & Niveau 2 & Niveau 3 & Niveau $4 / 5$ \\
\hline Basic school 1-6 (peruskoulu) & $52 \%$ & $41 \%$ & $7 \%$ & $0 \%$ \\
\hline Basic school 7-9 (peruskoulu) & $16 \%$ & $35 \%$ & $37 \%$ & $11 \%$ \\
\hline Secondary school (toisen asteen koulu) & $6 \%$ & $25 \%$ & $44 \%$ & $25 \%$ \\
\hline College (opisto) & $15 \%$ & $52 \%$ & $34 \%$ & $0 \%$ \\
\hline University (yliopisto) & $0 \%$ & $8 \%$ & $46 \%$ & $45 \%$ \\
\hline Alle deltagere i den finske del af SIALS & $10 \%$ & $26 \%$ & $41 \%$ & $22 \%$ \\
\hline
\end{tabular}

Tabel 10: Finners læsning af dokument-tekster (document literacy) i forhold til uddannelsesniveau

\begin{tabular}{lrrrr}
\hline Uddannelsesniveau & Niveau 1 & Niveau 2 & Niveau 3 & Niveau 4/5 \\
\hline Basic school 1-6 (peruskoulu) & $58 \%$ & $33 \%$ & $8 \%$ & $0 \%$ \\
Basic school 7-9 (peruskoulu) & $20 \%$ & $33 \%$ & $34 \%$ & $12 \%$ \\
Secondary school (toisen asteen koulu) & $7 \%$ & $23 \%$ & $42 \%$ & $28 \%$ \\
College (opisto) & $0 \%$ & $16 \%$ & $48 \%$ & $35 \%$ \\
University (yliopisto) & $0 \%$ & $8 \%$ & $39 \%$ & $52 \%$ \\
Alle deltagere i den finske del af SIALS & $13 \%$ & $24 \%$ & $38 \%$ & $25 \%$ \\
\hline
\end{tabular}

\subsubsection{Undersøgelser vedrørende lasning og skrivning $i$ arbejdssammenhceng}

Der er ikke rapporteret data fra Finland, der kan belyse kortuddannedes læsning og skrivning i arbejdssammenhæng.

\subsubsection{Undersøgelser vedrørende lasning og skrivning $i$ uddannelsessammenhreng}

3.5.4.1 Omfang af læse- og skrivevanskeligheder blandt deltagere i voksenuddannelse og på folkehøjskoler

Kakkuri (1993) gennemførte en undersøgelse af læse-, stave-, og skrivefærdighederne hos i alt 1196 voksne deltagere i forskellige kurser og 
uddannelser. ${ }^{47} 809$ af disse deltog i erhvervsrettet voksenuddannelse (finsk: aikuiskoulutus), 292 deltog i arbejdsmarkedsuddannelser primært rettet mod arbejdsløse (työvoimakoulutus), og 95 deltog i kurser på folkehøjskoler (kansanopisto). Hovedparten af deltagerne var mellem 30 og 39 år. På basis af en test af deltagernes læseforståelse blev det vurderet, at over $20 \%$ af dem havde vanskeligheder med at løse opgaver, hvor der skulle drages følgeslutninger på basis af informationer i de anvendte tekster. På grundlag af en diktat vurderedes det, at 19,3 \% af deltagerne havde stavevanskeligheder. Deltagernes resultater på en skrivetest, hvor de skulle beskrive udførslen af en arbejdsopgave, indikerede, at 3,7 \% af dem havde vanskeligheder med funktionel skrivning.

Deltagernes skole- og uddannelsesbaggrund blev undersøgt og sammenholdt med deres præstationer på testene af læsning, stavning og skrivning. Ikke overraskende viste undersøgelsen, at deltagere, som kun havde gennemført grundskolen, generelt klarede sig dårligere på testene end deltagere, som havde en uddannelse ud over grundskolen.

\subsubsection{Omfang af læsevanskeligheder blandt deltagere i social- og} sundhedsuddannelser

Pöyhönen (1997) gennemførte en undersøgelse blandt 417 deltagere på erhvervsuddannelser inden for social- og sundhedsområdet på en uddannelsesinstitution i Harjavalta. ${ }^{48}$ Deltagerne var mellem 17 og 52 år, og hovedparten af dem (363) var kvinder. Nogle af deltagerne havde ingen uddannelse ud over grundskolen, mens andre havde studentereksamen eller en erhvervsuddannelse. Deltagernes færdigheder i læseforståelse og afkodning blev afdækket med test, som var standardiseret i forhold til elever i 6 . klasse. Undersøgelsen viste, at omkring $16 \%$ af de kvindelige deltagere og $11 \%$ af de mandlige opnåede resultater på testen af læseforståelse, som lå under normen for 6 . klasse. På afkodningstesten præsterede knap $4 \%$ af deltagerne af begge køn under normen for 6 . klasse.

\subsubsection{Omfang af læsevanskeligheder blandt deltagere i tekniske} erhvervsuddannelser

Pajukoski \& Koskinen (2003) foretog i forbindelse med det såkaldte NÄYTTÖ-projekt (jf. afsnit 4.5.3.4) en undersøgelse af deltagerne i omkring 30 klasser på tekniske erhvervsuddannelser i Helsinki. ${ }^{49}$ Deltagerne

\footnotetext{
${ }^{47}$ Kakkuri, I. (1993). Aikuisten lukemis- ja kirjoittamisongelmat ammatillisessa aikuiskoulutuksessa, työvoimakoulutuksessa ja kansanopistossa. [,Adults’ reading and writing difficulties in vocational adult education, manpower education and folk high school“]. Jyväskylä: University of Jyväskylä, Department of Special Education.

${ }^{48}$ Pöyhönen, A. (1997). Lukemisvaikeus ammatillisessa koulutuksessa aikuisopiskelijan kokemuksena. [„Adult students experience of reading difficulty in vocational school“]. Turku: University of Turku, Department of Education. (Unpublished Master's thesis).

${ }^{49}$ Pajukoski, S. \& Koskinen, S. (2003). Erilaiset oppijat näytöissä, osaraportti II. Opetus, ohjaus ja näytön toteutus ammatillisessa peruskoulutuksessa. [„„Diverse learners in skills demonstrations, project report II. Teaching, instruction and organising skills demonstration in vocational secondary school“"]. Helsinki: Helsingin seudun erilaiset oppijat ry (HERO). (http://www.saunalahti.fi/mik4/ naytto-projekti/tiedostot/2.valiraportti.doc)
} 
blev testet med en læsetest, der var standardiseret i forhold til elever i 6 . klasse. På basis af undersøgelsens resultater vurderedes det, at omkring $34 \%$ af de deltagere, der fulgte den ordinære undervisning, havde læsevanskeligheder. Blandt deltagere, der gik til specialundervisning, var andelen $80 \%$.

3.5.4.4 Omfang af læsevanskeligheder blandt gymnasieelever og deltagere i erhvervsuddannelser

Södra Finlands Skriv- och Läsprojekt (SF-SOL) rettede sig mod finlandssvenske unge.

I perioden 2000-2002 deltog alle førsteårselever på fire erhvervsskoler og et gymnasium i test, der afdækkede færdigheder i ordkendskab, læseforståelse, afkodning og stavning. ${ }^{50}$ På basis af testresultaterne fra 2001 blev det vurderet, at over $40 \%$ af deltagerne inden for hotel og restaurant-området samt bil og transport-området på erhvervsskolerne havde svage læse- og stavefærdigheder. For gymnasiet var det tilsvarende tal 17 $\%$. Det fremgår ikke af rapporten, hvilke kriterier der blev lagt til grund for at kategorisere deltagerne som havende svage læse- og stavefærdigheder.

\subsection{Sverige}

\subsubsection{Sammenfatning vedrørende undersøgelser af omfanget af lesevanskeligheder blandt kortuddannede i Sverige}

I OECD's undersøgelse International Adult Literacy Survey (IALS) blev der indsamlet data fra Sverige i 1994 (jf. afsnit 3.6.2.1). Gruppen af deltagerne, som ikke havde gennemført grundskolen, var stærkt overrepræsenterede blandt de dårlige læsere i den svenske del af IALS. I alt 60,6 \% af denne gruppe placerede sig således under OECD’s minimumskriterium, hvilket var en langt større andel end den tilsvarende andel i den svenske deltagergruppe som helhed (25,1\%). De deltagere, som havde et uddannelsesniveau svarende til grundskolen, forekom imidlertid ikke at adskille sig markant fra deltagergruppen som helhed. Indvandrere var overrepræsenterede blandt de dårlige læsere, specielt den gruppe af indvandrere, som ikke havde forhøjet deres uddannelsesniveau, efter at de havde bosat sig i Sverige.

\footnotetext{
${ }^{50}$ HERO/Herosak (2003). SF-SOL. Södra Finlands Skriv- och Läsprojekt 2001/2002. Helsinki: HERO/Herosak.
} 
3.6.2 Undersøgelser af kortuddannedes lcese-, stave- og skrivefcerdigheder

3.6.2.1 Omfanget af læsevanskeligheder blandt voksne svenskere med særligt fokus på kortuddannede - belyst ved delresultater fra International Adult Literacy Survey (IALS)

\section{A. Omfanget af leesevanskeligheder i den voksne befolkning som helhed}

I alt 3.000 repræsentativt udvalgte personer mellem 16 og 66 år deltog i den svenske del af $I A L S$, som blev gennemført i $1994 .^{51}$ På en test af læsning af fortløbende tekster som avisartikler og brochurer (,prose literacy“) klarede 27,8 \% af de svenske deltagere sig så ringe, at de ikke levede op til det af OECD fastsatte minimumskriterium. Således opnåede $7,5 \%$ af de svenske deltagere resultater, der svarer til niveau 1 , dvs. det laveste af OECD's fem niveauer, mens 20,3 \% af deltagerne befandt sig på niveau 2. På en test af forståelse af dokumenttekster som tidstabeller, diagrammer, kort og blanketter („document literacy“) præsterede 25,1 under OECD’s minimumskriterium. Således befandt 6,2 \% sig ifølge denne test på niveau 1 og 18,9 \% på niveau 2.

\section{B. Omfanget af lasevanskeligheder blandt kortuddannede}

De svenske deltageres uddannelsesniveau er i Skolverkets rapport om IALS blevet vurderet og rapporteret med udgangspunkt i UNESCO's klassifikationssystem „International Standard Classification of Educational Systems“ (ISCED). Som det fremgår af tabellen nedenfor, havde $22,5 \%$ af deltagerne, som ikke havde gennemført grundskolen, færdigheder på niveau 1 på testen af lresning af dokumenttekster, mens 38,1 \%

Tabel 11: Svenskeres læsning af dokument-tekster („document literacy“) i forhold til uddannelsesniveau

\begin{tabular}{lrrrr}
\hline Uddannelsesniveau & $\begin{array}{r}\text { Niveau 1 } \\
\%\end{array}$ & $\begin{array}{r}\text { Niveau 2 } \\
\%\end{array}$ & $\begin{array}{r}\text { Niveau 3 } \\
\%\end{array}$ & $\begin{array}{r}\text { Niveau 4/5 } \\
\%\end{array}$ \\
\hline $\begin{array}{l}\text { Lavere end "grundskola“ (ISCED mindre } \\
\text { end 02) }\end{array}$ & 22,5 & 38,1 & 33,2 & 6,2 \\
$\begin{array}{l}\text { "Grundskola“ (ISCED 02) } \\
\text { "Högskoleforberedande gymnasieutbil- }\end{array}$ & 6,8 & 16,9 & 45,5 & 30,8 \\
ding" (ISCED 03) & 3,9 & 19,1 & 42,1 & 34,9 \\
„Högskoleutbilding" mindre end 3 år & 1,1 & 11,1 & 37,8 & 50,1 \\
(ISCED 05) & & & & \\
"Universitetsutbilding" (ISCED 06/07) & 0,7 & 8,1 & 29,8 & 61,4 \\
Alle deltagere i den svenske del af IALS & 6,2 & 18,9 & 39,4 & 35,5 \\
\hline
\end{tabular}

af disse deltagere havde færdigheder svarende til niveau 2. I alt 60,6 \% af denne gruppe placerede sig således under minimumskriteriet, hvilket var en langt større andel end den tilsvarende andel i den svenske deltager-

\footnotetext{
${ }^{51}$ Skolverket (1996). Grunden för fortsatt lärande - En internationell jämförande studie av vuxnas förmåga att förstå och använda tryckt och skriven information. Stockholm: Skolverket.
} 
gruppe som helhed (25,1\%). De deltagere, som havde et uddannelsesniveau svarende til grundskolen, forekom imidlertid ikke at adskille sig markant fra deltagergruppen som helhed. Således befandt i alt 23,7 \% af deltagerne med et uddannelsesniveau svarende til grundskolen sig på de to laveste niveauer, mens dette som nævnt gjaldt for $25,1 \%$ af hele deltagergruppen.

Skolverkets rapport indeholder ikke oplysninger om de forskellige uddannelsesgruppers resultater på testen af lcesning af prosatekster (,prose literacy“). Af Gustavssons senere rapport om den svenske del fremgår det imidlertid, at mens i alt $37 \%$ af de undersøgte placerede sig på niveau 1 eller 2 på denne test, var den tilsvarende andel blandt personer med 8 års skolegang eller mindre $78 \%$ og blandt personer med afsluttet grundskole $38 \%{ }^{52}$ I Gustavssons rapport er de forskellige uddannelsesgruppers placering på niveau 1 og 2 behandlet under én kategori, og det fremgår således ikke, hvor mange der befandt sig på hvert af disse to niveauer.

\section{Omfanget af lasevanskeligheder blandt indvandrere}

I forbindelse med den svenske deltagelse i OECD-undersøgelsen IALS og parallelt med den efterfølgende undersøgelse SIALS har Myrberg et al. gennemført en undersøgelse af læsefærdigheder hos i alt 546 indvandrere i alderen 16-65 år. ${ }^{53}$ På testen af læsning af fortløbende prosatekster (,prose literacy0147) opnåede knap $30 \%$ af indvandrerne resultater, der svarer til niveau 1 , dvs. det laveste af OECD's fem niveauer, mens godt $30 \%$ af denne gruppe befandt sig på niveau 2. Andelen af indvandrere, der befandt sig på de to laveste niveauer, var væsentligt højere end den tilsvarende andel blandt indfødte svenskere.

Blandt de undersøgte indvandrere havde 4 ud af 10 en skolebaggrund, der svarede til grundskoleniveau eller lavere. Til sammenligning gjaldt dette kun for 3 ud af 10 i befolkningen som helhed. Blandt indvandrere med skolebaggrund svarende til grundskole eller lavere klarede kun $2 \%$ sig på niveau 4/5 på testen af læsning af prosatekster. Fordelingen af de kortuddannede indvandrere på de øvrige niveauer fremgår ikke af rapporten.

Omkring en femtedel af de undersøgte indvandrere havde forhøjet deres uddannelsesniveau efter ankomsten til Sverige. Blandt dem, der havde forhøjet deres uddannelsesniveau i Sverige, placerede $56 \%$ sig på de to laveste niveauer på testen af læsning af prosatekster. Til sammenligning gjaldt dette for $80 \%$ af de indvandrere, der ikke havde forhøjet deres uddannelsesniveau efter ankomsten til Sverige.

\footnotetext{
${ }^{52}$ Gustavsson, A-L.E. (1997). Att läsa - ett behov, ett krav, en nödvändighet. En analys av den första internationellt jämförande studien av vuxnas förmåga att förstå och använda skriftlig information. International Adult Literacy Survey. Linköpings universitet: Institutionen för pedagogik och psykologi.

${ }^{53}$ Myrberg, M., Gustavsson, A-L.E. \& Ericsson, Å. (2000). International Adult Literacy Survey: Invandrares läs-, skriv- och räkneförmåga. Linköpings Universitet, Läspedagogiska Institutet EMIR. (http://skolnet.skolverket.se/pdf/ials.pdf)
} 


\subsubsection{Undersøgelser vedrørende lessning og skrivning $i$ arbejdssammenhceng}

3.6.3.1 Kortuddannedes brug af læsning og skrivning i arbejdssammenhæng - belyst ved svenske delresultater fra International Adult Literacy Survey (IALS)

Gustavsson (1997) fandt i sin analyse af resultaterne fra den svenske del af IALS en tydelig sammenhæng mellem deltagernes uddannelsesniveau og deres læsevaner i arbejdssammenhæng. ${ }^{54}$ Eksempelvis læste kun 15 \% af deltagerne med maksimalt 8 års skolegang breve og meddelelser mindst én gang om ugen, mens de tilsvarende tal for personer med henholdsvis afsluttet grundskole og teoretisk gymnasial uddannelse var 42 og $46 \%$. Tilsvarende tendenser rapporteres vedrørende læsning af rapporter og manualer for de deltagere, der var i arbejde.

\subsubsection{Undersøgelser vedrørende leesning og skrivning i uddannelsessammenhæeng}

Der foreligger ingen oplysninger om større undersøgelser fra Sverige, der direkte belyser kortuddannedes læsning og skrivning i uddannelsessammenhæng.

\subsection{Diskussion vedrørende omfanget af læse- og skrivevanskeligheder}

I forbindelse med forprojektet ønskes en belysning af omfanget af læsevanskeligheder blandt kortuddannede i Norden. I kapitel 3 er der givet en oversigt over relevante undersøgelser i de forskellige nordiske lande. Undersøgelserne viser samstemmende, at der er en betydelig overrepræsentation af kortuddannede blandt voksne med ringe læsefærdigheder.

I de beskrevne læseundersøgelser har der været anvendt tekster af forskellig type og sværhedsgrad, lige som der i opgaverne er blevet stillet forskellige krav til deltagernes færdigheder. Undersøgelserne har således haft forskellige formål, og kriterierne for, hvad en person skal kunne klare af læseopgaver for at læse „godt nok“, varierer betydeligt. På denne baggrund er det ikke overraskende, at der på basis af undersøgelserne findes vidt forskellige tal for, hvor mange der har utilstrækkelige læsefærdigheder.

Eksempelvis har en dansk undersøgelse fra 1991 fundet, at cirka $21 \%$ af de kortuddannede i arbejde ikke opfyldte et fastsat minimumskrav ved

\footnotetext{
${ }^{54}$ Gustavsson, A-L.E. (1997). Att läsa - ett behov, ett krav, en nödvändighet. En analys av den första internationellt jämförande studien av vuxnas förmåga att förstå och använda skriftlig information. International Adult Literacy Survey. Linköpings universitet: Institutionen för pedagogik och psykologi.
} 
læsning af relativt lette dagligdags tekster som fx en artikel fra et formiddagsblad (jf. afsnit 3.2.2.2). Formodentlig var de anvendte tekster ikke vanskeligere end det læsestof, kortuddannede kan møde i arbejdssammenhæng, og teksterne kan antages at være væsentligt lettere end det materiale, kortuddannede kan møde i kursus- og uddannelsessammenhæng inden for deres område. Det er således sandsynligt, at de personer, der ikke levede op til minimumskriteriet i undersøgelsen, vil have vanskeligheder med at læse nogle af de tekster, de møder i arbejdssammenhæng og muligvis i endnu højere grad i kursus- og uddannelsessammenhæng. Men undersøgelsen giver ikke belæg for at fastslå, om det faktisk forholder sig således.

I OECD-undersøgelsen (Second) International Adult Literacy Survey, som fire af de nordiske lande har deltaget i, defineres funktionel læse- og skrivefærdighed som en persons „evne til at bruge trykt og skreven information med henblik på at fungere i samfundet, opnå sine mål, udvikle sin viden og sit potentiale og deltage i samfundet“. Færdigheder på niveau 3 af de i alt 5 opstillede niveauer anses af konsortiet bag undersøgelsen for at være det niveau, der er nødvendigt for at klare de krav, der stilles i dagligdagen og på arbejdet $\mathrm{i}$ et komplekst, moderne samfund. Niveau 3 antages endvidere at svare til det niveau, der er nødvendigt for at gennemføre „secondary school“ “. ${ }^{55}$ Der er således tale om, at personer for at læse „godt nok“ skal kunne bruge læsning som led i en personlig udvikling, blandt andet i uddannelsessammenhænge, hvor der typisk stilles relativt høje læsemæssige krav. I tråd hermed er hovedparten af de anvendte tekster og opgaver væsentligt vanskeligere end dem, der indgik i den ovenfor nævnte danske undersøgelse. Kriteriet for funktionel læsefærdighed er sat relativt højt, og det er derfor ikke overraskende, at der tilsvarende findes relativt høje tal for andelen af borgere, som ikke lever op til dette kriterium. Ifølge resultaterne fra (S)IALS placerede således omkring en tredjedel eller flere af de voksne i Norden sig under det fastlagte minimumskriterium. Som beskrevet i det foregående var de kortuddannede i alle de nordiske deltagende lande overrepræsenterede blandt de voksne, der ikke levede op til minimumskriteriet. Eksempelvis placerede hele $79 \%$ af danskerne uden nogen uddannelse ud over grundskolen sig således under minimumskriteriet (jf. 3.2.2.1), og blandt nordmændene var det tilsvarende tal lidt over $60 \%$, både i (S)IALS og i den nyere OECDundersøgelse Adult Literacy and Life Skills (ALL), som Norge som det eneste nordiske land har deltaget i (jf. 3.3.2.1 og 3.3.2.2).

Som udgangspunkt er det problematisk, at det ikke vides, hvor OECD har det omtalte minimumskriterium fra. Konsortiet bag (S)IALS og $A L L$ har ikke gennemført nogen undersøgelse af, om der er en sammenhæng mellem deltagernes præstationer på de anvendte læsetest og deltagernes faktiske færdigheder i at klare fx arbejde eller uddannelse. Det er derfor

${ }^{55}$ OECD (2000). Literacy in the Information Age: Final Report of the International Adult Literacy Survey. Paris: OECD. 
uvist, om de voksne, der ligger på de to laveste niveauer, faktisk har problemer med læsning i hverdagen. Andre har dog gjort forsøg på at relatere de fem læseniveauer til de krav, der stilles på arbejdsmarkedet. Barton (2000) har således gennemført en undersøgelse, hvor det amerikanske arbejdsministeriums beskrivelser af kravene i en række forskellige jobs blev analyseret og sammenholdt med de fem SIALS-læseniveauer. ${ }^{56}$ Undersøgelsen viste, at langt de fleste jobfunktioner inden for forskellige brancher faktisk forudsatte læsefærdigheder svarende til niveau 3 eller derover. Imidlertid var der også en mindre gruppe af jobs, der „kun“ forudsatte læsefærdigheder svarende til niveau 2, fx jobs som truckfører, hjemmehjælper, sygehjælper og køkkenhjælper. Med andre ord tyder resultaterne af den amerikanske undersøgelse på, at en del jobs, der typisk varetages af kortuddannede, kræver et vist niveau af læsefærdigheder, men ikke helt så højt som det, OECD har fastlagt som minimumsniveau. Undersøgelsen viser imidlertid ikke noget om, hvor store læsekrav der stilles til kortuddannede, hvis de ønsker at udvikle sig inden for deres område gennem kurser og uddannelse. Det er meget muligt, at læsekravene i disse sammenhænge reelt er højere end det, der svarer til niveau 2 i (S)IALS.

Spørger man de kortuddannede selv om deres læsning og skrivning i arbejdssammenhæng, tyder nordiske undersøgelser på, at kortuddannede gennemgående læser og skriver væsentligt mindre end personer, der har afsluttet en uddannelse efter grundskolen (jf. 3.2.3.2 og 3.3.3.1). Endvidere oplyser kun relativt få af de kortuddannede, at de oplever vanskeligheder med at læse og skrive på jobbet (jf. 3.2.3.1). Dette kan blandt andet hænge sammen med, at mange af de kortuddannede som nævnt netop ikke læser og skriver så meget og derfor heller ikke så tit oplever vanskeligheder. Den relativt begrænsede brug af læsning og skrivning kan skyldes, at mange tilpasser sig og nøjes med at påtage sig opgaver, som svarer til deres kompetencer og overlader mere læse- og skrivekrævende opgaver til andre. En del svage læsere kan allerede som unge også have fravalgt uddannelser, som fører til jobs med megen læsning og skrivning. ${ }^{57}$ Tilsvarende kan nogle medarbejdere med svage læsefærdigheder helt afholde sig fra at gå i gang med kurser og uddannelse, som formodes at kræve læsning.

Spørger man arbejdsgivere og virksomhedsledere, lader det til, at i hvert fald nogle af dem opfatter kortuddannede voksnes læse- og skrivefærdigheder som utilstrækkelige. Dette kommer blandt andet til udtryk i en norsk undersøgelse, som viste, at virksomhedsledere i mindre grad var tilfredse med de kortuddannede medarbejderes læse-, skrive- og ITfærdigheder end med de tilsvarende færdigheder blandt faglærte og højtuddannede medarbejdere (jf. 3.3.3.3). På basis af den konkrete undersø-

\footnotetext{
${ }^{56}$ Barton, P. (2000). What jobs require: Literacy, Education, and Training 1940-2006. Policy Information Report. Princeton NY: Educational Testing Service.

${ }^{57}$ Haven, D. (1998). Gode og dårlige læsere efter 9. klasse. Anden del af en efterundersøgelse. Psykologisk Pcedagogisk Rådgivning, 35(5/6), 454-472.
} 
gelse er det vanskeligt at vide, hvad virksomhedslederne har baseret deres vurderinger på. Det kan imidlertid tilføjes, at forskning uden for Norden tyder på, at en del ledere vurderer, at ringe læse- og skrivefærdigheder hos medarbejdere medfører store problemer på arbejdspladsen, blandt andet fordi de pågældende medarbejdere efter ledernes opfattelse misforstår skriftlig information eller undlader at videregive meddelelser på skrift. ${ }^{58}$ Imidlertid indikerer udenlandske undersøgelser også, at medarbejderne ofte selv vurderer, at eventuelle problemer på arbejdspladsen har helt andre årsager, som fx at ledelsen giver modstridende meldinger vedrørende kravene om skriftlig dokumentation. ${ }^{59}$ Dette område er ikke velbelyst i nordisk sammenhæng.

Det er vanskeligt at fastslå omfanget af læsevanskeligheder blandt kortuddannede i arbejdssammenhæng, hvilket hænger sammen med, at sådanne eventuelle vanskeligheder må afhænge af de læsekrav, som de kortuddannede faktisk møder. Der findes foreløbig kun ganske få nordiske undersøgelser, der fokuserer på de læsekrav, der stilles til kortuddannede voksne på arbejdsmarkedet. Et bud på omfanget af læsevanskeligheder blandt kortuddannede må derfor nødvendigvis være forbundet med stor usikkerhed. Dog forekommer det ikke urimeligt at fastslå et mindstetal på omkring $20 \%$ med henvisning til resultaterne af den omtalte undersøgelse af danskeres læsefærdigheder (jf. 3.2.2.2). Det faktiske tal kan meget vel være væsentligt højere, især hvis man, som OECDundersøgelserne lægger op til, også kræver, at kortuddannede skal kunne bruge læsning som led i en personlig udvikling, fx i kursus- og uddannelsessammenhænge.

I uddannelses- og kursussammenhænge kan læse- og skrivevanskeligheder blive et (endnu) større problem end i det daglige arbejde. I den danske del af SIALS fandt Jensen et al. som tidligere omtalt (jf. afsnit 3.2.2.1), at ufaglærte gennemsnitligt i mindre omfang deltog i kurser med et erhvervsmæssigt/fagligt formål end personer med en uddannelse ud over grundskolen. ${ }^{60}$ Dette gjaldt i særlig grad for de ufaglærte med ringe læsefærdigheder. En mulig forklaring kan være, at kortuddannede svage læsere fravælger at deltage i kurser og uddannelse, fordi de tidligere har oplevet nederlag i forbindelse med skolegang og selv frygter, at de ikke vil kunne gennemføre eller ikke vil kunne få udbytte af kurser og uddannelse. Dette kan være problematisk, da medarbejdere, der ikke har nogen uddannelse og heller ikke dygtiggør sig gennem kurser inden for deres

\footnotetext{
${ }^{58}$ Hull, G., Jury, M., Ziv, O. \& Katz, M. (1996). Changing work, changing literacy: A study of skill requirements and development in a traditional and restructured workplace (Final Report). Berkeley, CA: National Center for Research in Vocational Education, Center for the Study of Writing and Literacy.

${ }^{59}$ Belfiore, M.E. (2004). Reading Work. Literacies in the New Workplace. Mahwah: New Jersey: Lawrence Erlbaum Associates.

${ }^{60}$ Jensen, T.P., Andersen, A. \& Halgreen, T. (2001). Læefererdigheder og deltagelse i samfundslivet. København: Amternes og Kommunernes Forskningsinstitut \& Specialarbejderforbundet i Danmark (SID).
} 
felt, alt andet lige må antages at have en øget risiko for at blive marginaliserede og sat helt uden for arbejdsmarkedet.

I kapitel 3 er der beskrevet en del undersøgelser, der har belyst omfanget af læsevanskeligheder i forskellige kurser og uddannelser. Det er fx blevet undersøgt, hvor stor en del af deltagerne på en bestemt uddannelse der på en eller flere test placerer sig under et bestemt niveau. Eksempelvis har en dansk undersøgelse således fundet, at omkring $40 \%$ af deltagerne i arbejdsmarkeds- og erhvervsuddannelser havde læse- og stavefærdigheder, der højst svarede til gennemsnittet for skoleelever midt i 5. klasse (jf. 3.2.4.3), mens en finsk undersøgelse viste, at 11-16 \% af deltagerne i social- og sundhedsuddannelser præsterede under normen for 6. klasse på en test af læseforståelse (jf. 3.5.4.2). Problemet med sådanne undersøgelser er imidlertid, at det er usikkert, om det anvendte kriterium er relevant. Man kan ikke vide, om deltagere, der præsterer under niveauet for fx 5. eller 6. klasse, faktisk har problemer med læsning i deres uddannelse. Der mangler med andre ord en ekstern validering af kriteriet. I de nævnte eksempler kan de valgte kritiske grænser i virkeligheden meget vel tænkes at være sat for lavt, da de undervisningsmaterialer, som anvendes i uddannelsessammenhæng, sprogligt og indholdsmæssigt kan være langt vanskeligere at forstå end de materialer, der anvendes på mellemtrinnet i grundskolen. 


\section{Tilbud og tiltag for voksne med utilstrækkelige læse-, stave- og skrivefærdigheder i Norden}

\subsection{Indledning}

Forprojektet skal bidrage med en indledende afklaring af art og omfang af private og offentlige tilbud om læse-staveundervisning. Målet med forprojektet er at indsamle og sammenfatte den eksisterende dokumentation af de offentlige tilbud i de nordiske lande - og eksempler på initiativer i private virksomheder eller organisationer.

Utilstrækkelige læse-, stave- og skrivefærdigheder kan skyldes forskellige forhold og ytre sig på forskellig vis. Nogle mennesker er ordblinde (dyslektikere); de har specifikke vanskeligheder med sprogets lydside og har typisk helt fra skolestarten oplevet store problemer med at stave og afkode ord. Andre har et andet modersmål end majoriteten i landet og kan opleve, at et utilstrækkeligt ordforråd og/eller manglende læse- og skrivetræning på majoritetssproget vanskeliggør læsning og skrivning i hverdagen. Atter andre kan opleve vanskeligheder med læsning og skrivning grundet $\mathrm{fx}$ utilstrækkeligt udbytte af undervisningen $\mathrm{i}$ grundskolen, manglende vedligeholdelse af læse- og skrivefærdigheder eller en stigning i hverdagens krav til læse- og skrivefærdigheder som følge af jobskifte eller start på uddannelse. Undervisningstilbud og tiltag for voksne med læse-, stave- og skrivevanskeligheder vil i nogle tilfælde rette sig specifikt mod en enkelt af de nævnte grupper, og i andre tilfælde mod flere. Der fokuseres i dette kapitel på følgende typer af tilbud og tiltag i de enkelte lande:

- Tilbud og tiltag i arbejds- og fritidssammenhænge for voksne med læse-, stave- og skrivevanskeligheder, herunder ordblinde. I denne sammenhæng behandles også tilbud om læse-skriveundervisning for arbejdsløse.

- Støtteforanstaltninger i uddannelsessammenhænge for personer med læse-, stave- og skrivevanskeligheder. Beskrivelsen har særligt fokus på foranstaltninger i formelt kompetencegivende uddannelser, som er praktisk orienterede og/eller rettede mod kortuddannede voksne.

- Særlige tilbud for indvandrere med flere. Beskrivelsen har fokus på tilbud, som specielt sigter mod at forbedre læse-, skrive- og IT-færdigheder hos personer, som har et andet modersmål end majoriteten $\mathrm{i}$ det land, hvor de bor. Det ligger uden for projektets rammer at give 
en indgående behandling af den almene sprogundervisning, som tilbydes i de enkelte lande.

Der gives i dette kapitel for hvert af de fem nordiske lande en oversigt over eksisterende tilbud og tiltag inden for de nævnte områder. Indledningsvis gives der for hvert land en sammenfatning af de vigtigste tilbud og tiltag, som efterfølges af en mere detaljeret gennemgang. Hvis der foreligger skriftlige rapporter vedrørende undersøgelser af effekten af de beskrevne tilbud og tiltag, resumeres resultaterne af sådanne undersøgelser umiddelbart efter beskrivelserne. Der redegøres endvidere for tidligere og igangværende forsknings- og udviklingsprojekter af relevans for forprojektet, hvis der foreligger tilgængelige beskrivelser af projekterne.

Efter oversigten over tiltagene i de enkelte nordiske lande følger et afsnit med omtale af fælles-nordiske tiltag (jf. afsnit 4.7). Kapitlet afrundes med en diskussion vedrørende de nordiske tilbud og tiltag (jf. 4.8).

\subsection{Danmark}

\subsubsection{Sammenfatning vedrørende danske tilbud og tiltag}

I Danmark eksisterer der et tilbud om forberedende voksenundervisning (FVU) i lcesning, stavning og skriftlig fremstilling på fire trin for voksne, som har behov for at forbedre og supplere deres grundlæggende færdigheder på disse områder (jf. nærmere beskrivelse af tilbuddet i afsnit 4.2.1.1). FVU har siden 2001 afløst et tidligere tilbud om læsekurser for voksne og er de sidste par år blevet evalueret i flere undersøgelser baseret på interviews med udbydere, undervisere og deltagere. Der er desuden gennemført en træningsundersøgelse, hvor effekten af forskellige typer undervisning blev målt på udviklingen af FVU-deltagernes færdigheder i læsning, skrivning og relaterede områder. Den sidstnævnte undersøgelse viste, at FVU-deltagerne gennemsnitligt havde en beskeden, men dog signifikant fremgang inden for de undersøgte områder. Samtidig viste denne undersøgelse, at tosprogede og ordblinde deltagere i ringere grad end andre deltagere profiterede af undervisningen, hvilket kan indikere, at FVU ikke er det optimale tilbud for disse grupper.

Som et særligt tilbud for ordblinde voksne udbydes der ordblindeundervisning, hvor holdstørrelsen gennemgående er væsentlig mindre end i FVU (jf. nærmere beskrivelse af ordblindeundervisningstilbuddet i afsnit 4.2.2.2). Der er for cirka ti år siden gennemført to undersøgelser af effekten af deltagelse i specialundervisning på ordblinde deltageres færdigheder i læsning, stavning og relaterede områder. Begge undersøgelser viste gennemsnitligt relativt beskedne fremgange i deltagernes færdigheder, men markante fremgange for en mindre del af deltagerne. 
Det er muligt for voksne ordblinde at få bevilliget IT-hjœelpemidler under forskellige ordninger, og der er pt. en undersøgelse i gang, der søger at belyse effekten af voksne ordblindes brug af sådanne hjælpemidler (jf. 4.2.2.6). Desuden er der igangsat et forskningsprojekt, hvor der udvikles et hjælpemiddel og mobil e-læring til læsesvage og ordblinde, i første omgang specielt rettet mod ansatte i byggebranchen (jf. 4.2.2.7).

Af støtteforanstaltninger i uddannelsessammenhænge findes ordningen om specialpæedagogisk støtte (SPS), fx på erhvervsuddannelser (jf. 4.2.3.1). Denne ordning indebærer, at ordblinde blandt andet kan få særligt tilrettelagte undervisningsforløb, hjælpemidler og særlige vilkår under eksaminer. Endvidere gennemføres der p.t. forsøg med ord- og regnevcerksteder rettet mod kortuddannede voksne, som deltager i erhvervsrettet voksen- og efteruddannelse (jf. 4.2.5.4). Ord- og regneværkstederne tilbyder blandt andet individuelt tilpasset supplerende undervisning i læsning, skrivning, regning og matematik i tilknytning til undervisningen på de erhvervsrettede efteruddannelser.

\subsubsection{Tilbud og tiltag i arbejds- og fritidssammenhæenge}

4.2.2.1 Tilbud om Forberedende voksenundervisning (FVU) i læsning, stavning og skriftlig fremstilling

\subsection{Beskrivelse af tilbud}

Siden 2001 har der i Danmark været udbudt forberedende voksenundervisning (FVU) i læsning, stavning og skriftlig fremstilling. Formålet med FVU er at give voksne mulighed for at forbedre og supplere deres grundlæggende færdigheder i læsning, stavning og skriftlig fremstilling med henblik på videre uddannelse samt at styrke voksnes forudsætninger for aktiv medvirken i alle sider af samfundslivet. Alle, som er fyldt 18 år, og som har forudsætninger for at følge undervisningen med udbytte, har adgang til FVU. ${ }^{61}$ Inden for rammerne af FVU findes der endvidere et tilbud om undervisning i grundlæggende matematikfærdigheder, men i det følgende behandles udelukkende tilbuddet om den forberedende voksenundervisning i læsning, stavning og skriftlig fremstilling (som i daglig tale og i det følgende forkortes til FVU-læsning).

FVU-læsning er opdelt i fire successive undervisningstrin, som hver strækker sig over 40-60 timer. Der undervises på de fire trin på forskellige niveauer inden for følgende områder: lydfølgeregler, orddannelse, ordkendskab, læseforståelse, skriftlig fremstilling og brug af skrevne tekster i hverdagen. På alle trin arbejdes der med IT som redskab. Der er mulighed for samlæsning af deltagere på forskellige trin. FVU-læsning kan på trin 1 tilrettelægges særligt for deltagere, der har dansk som andet-

\footnotetext{
${ }^{61}$ Lov om forberedende voksenundervisning (FVU-loven). LBK nr 16 af 07/01/2005. (http://www.retsinfo.dk/_GETDOCM /ACCN/A20050001629-REGL)
} 
sprog, og for ordblinde deltagere. Efter hvert trin har deltagerne mulighed for at aflægge en prøve. ${ }^{62}$

Undervisningsministeriet anbefaler, at der inden undervisningens begyndelse foretages en indledende afdækning af deltagernes færdigheder inden for læsning, stavning og skriftlig fremstilling som grundlag for trinplacering og planlægning af undervisning. Der er udviklet testmaterialer, som kan anvendes til at foretage en sådan afdækning af deltagernes færdigheder. ${ }^{63}$ Der er endvidere et nyt screeningsmateriale under udvikling for Undervisningsministeriet. Det vil for uddannelsesstederne blive obligatorisk at anvende dette materiale i forbindelse med optagelse til FVU. ${ }^{64}$

Det er gratis for deltagerne at følge undervisningen. Kortuddannede deltagere mellem 20 og 60 år kan modtage Statens voksenuddannelsesstøtte (SVU) under et FVU-forløb. Hvis sådanne deltagere går til FVU i arbejdstiden og oppebærer fuld løn, kan den økonomiske støtte udbetales til arbejdsgiveren. ${ }^{65}$

FVU foregår blandt andet på voksenuddannelsescentrene (VUC), som i forbindelse med en omfattende strukturreform i 2007 er blevet selvejende institutioner under staten. Voksenuddannelsescentrene kan indgå driftsoverenskomster med andre udbydere om at tilbyde FVU. FVU kan således også foregå på fx daghøjskoler, erhvervsskoler, arbejdsmarkedsuddannelsescentre, produktionsskoler, social- og sundhedsskoler, folkehøjskoler, aftenskoler, sprogcentre og skoler med specialundervisning for voksne. Undervisningen kan endvidere forlægges til virksomheder.

Langt de fleste FVU-kurser finder sted på voksenuddannelsescentre (VUC). Rekrutteringen til FVU foregår ofte gennem andre undervisningstilbud som den almene voksenuddannelse (AVU) på VUC. I nogle tilfælde screenes deltagere i de ordinære undervisningstilbud for læse- og stavevanskeligheder og får oplysning og tilbud om FVU, hvis screeningen afslører utilstrækkelige færdigheder. Desuden anvender mange af FVUudbyderne brochurer, annoncer og radiospots til at informere potentielle deltagere om FVU, lige som en del udbydere har opsøgende konsulenter, der informerer om muligheden for at etablere FVU på virksomheder. ${ }^{66}$

\footnotetext{
${ }^{62}$ Undervisningsministeriet (2002). Undervisningsvejledning. Forberedende voksenundervisning (FVU) i læesning, stavning og skriftlig fremstilling. København: Undervisningsministeriet. (http://us.uvm.dk/voksen/fvu/undervisningsvejl laesning.pdf)

${ }^{63}$ Undervisningsministeriet (2004). Vejledning til trinplacering (2. udgave). Afdækning af FVUdeltageres erfaringer, færdigheder og strategier i læsning, stavning og skriftlig fremstilling. København: Undervisningsministeriet.

(http://us.uvm.dk/voksen/fvu/Vejledninger/documents/Trinplacering-laes-vejl-juni04-vejl.pdf)

${ }^{64} \mathrm{Jf}$. meddelelse på Undervisningsministeriets elektroniske opslagstavle for FVU 7. marts 2007. (http://us.uvm.dk/voksen/fvu/opslagstavlen.htm?menuid=350525)

${ }^{65}$ Undervisningsministeriet (2004). Fakta om FVU. København: Undervisningsministeriet. (http://us.uvm.dk/voksen/fvu/fvu-cases/fakta_om_fvu.htm?menuid=350525)

${ }^{66}$ Danmarks Evalueringsinstitut (2005). Forberedende voksenundervisning. København: Danmarks Evalueringsinstitut. (http://217.61.44.102/Admin/Public/download.aspx?file=Files/Filer/ Rapporter\%202004/Forberedende\%20voksenundervisning/FVU-rapport.pdf )
} 
En mindre del af FVU-kurserne foregår lokalt på virksomheder. Til illustration nedenfor nævnes nogle eksempler på virksomhedsforlagte FVU-forløb, hvor medarbejderne deltog i undervingen i arbejdstiden og oppebar fuld løn.

- FVU for specialarbejdere i virksomheden Dansk Eternit i Aalborg. Undervisningen fandt sted i et særligt indrettet lokale på fabrikken og blev varetaget af en lærer fra Arbejdernes Oplysningsforbund (AOF) i Aalborg. ${ }^{67}$

- FVU for bygningsarbejdere i entreprenørvirksomheden NCC. Undervisningen foregik i en skurvogn på Danmarks Radios byggeplads for det nye multimediehus i Ørestaden (DR-byen) og blev forestået af en lærer fra Københavns Kvindedaghøjskole. Projektet blev gennemført i et samarbejde mellem NCC, DR-byen, Specialarbejderforbundet $i$ Danmark (SID), Bygge- og Anlægsbranchens uddannelsesfond, Københavns Kvindedaghøjskole og FVU-team Storkøbenhavn. ${ }^{68}$

- FVU for medarbejdere i Greve Kommunes hjemmepleje, herunder social- og sundhedshjælpere og social- og sundhedsassistenter. Undervisningen blev varetaget af en underviser fra VUC i Roskilde Amt. Projektet blev gennemført i et samarbejde mellem Roskilde Amt, Greve Kommune og VUC i Roskilde Amt. ${ }^{69}$

Der er siden 2001 på forskellig vis blevet informeret om FVU-tilbuddet. Eksempelvis har Undervisningsministeriet i samarbejde med Amtsrådsforeningen og landets amter stået for en landsdækkende informationskampagne om FVU i form af lokale radio- og tv-spots, skilte i landets busser og toge samt en amtslig hotline-service, hvor interesserede kunne henvende sig. ${ }^{70}$ Danmarks Radio (DR) har sendt en række tv-programmer om temaet læse- og stavevanskeligheder og i den forbindelse informeret om muligheden for at deltage i FVU. Endvidere er der en række FVUkonsulenter, som udfører opsøgende arbejde, og der er for midler fra EU's Socialfond publiceret en vejledning vedrørende igangsættelse af FVU-kurser på virksomheder inden for forskellige brancher. ${ }^{71}$

Det samlede antal holdkursister i FVU-læsning var i 2005 20.508. ${ }^{72}$

\footnotetext{
${ }^{67}$ Engell, L. V. (2003). Derfor FVU på arbejdspladsen! København: Undervisningsministeriet. (http://us.uvm.dk/voksen/fvu/fvu-cases/alle_artikler.pdf).

${ }^{68}$ Undervisningsministeriet (2004). Konferencerapport fra FVU-lcererkonferencen 2004. Nye veje for voksne i arbejde København: Undervisningsministeriet. (http://us.uvm.dk/voksen/fvu/information_generel/konferencerapport fvu-ny.pdf)

${ }^{69}$ NIRAS-konsulenterne (2006). Evaluering af kompetenceudviklingsprojekt „Skriftlig kommunikation" for medarbejdere i Greve Kommunes Hjemmepleje. Slutevaluering. Roskilde: Roskilde Amt.

${ }^{70}$ Københavns Kommune (2005). Spids pennen - en evaluering af hotlinefunktionen. København: Undervisningsministeriet. (http://us.uvm.dk/voksen/fvu/documents/hotlinefunktionen.pdf)

${ }^{71}$ Pedersen, L.B.T. \& Løvengreen, K. (2006). Brancherettet FVU - et idékatalog om information og tilrettelæggelse af FVU på virksomheder. København: FVU-team Storkøbenhavn.

(http://www.fvu-team.dk/pdf/opsoegerkatalog_samlet.pdf)

${ }^{72}$ Danmarks Evalueringsinstitut (2006). Forberedende voksenundervisning. Årsrapport 2006. København: Danmarks Evalueringsinstitut.
} 


\subsection{Undersøgelser af effekten af deltagelse i tilbuddet}

Siden FVU-lovens ikrafttræden er FVU-tilbuddet blevet evalueret og belyst gennem forskellige undersøgelser. I det følgende resumeres vigtige resultater af disse undersøgelser.

A. En træningsundersøgelse med afprøvning af to undervisningsmaterialer til udvikling af voksne deltageres bevidsthed om og udbytte af FVUleesning

Arnbak \& Borstrøm (2004) gennemførte en afprøvning af to forskellige materialer til udvikling af voksne deltageres bevidsthed om og udbytte af FVU-læsning. ${ }^{73}$ De anvendte materialer var udviklet specielt til FVU. Det ene materiale havde fokus på underviserens og deltagernes løbende registrering og evaluering af deltagernes arbejde med skriftsproget og udbytte af undervisningen i en struktureret FVU-logbog. Det andet materiale havde fokus på processer i skrivning af hverdagstekster. I undersøgelsen modtog en gruppe på i alt 112 deltagere undervisning, der var organiseret omkring brugen af det første materiale, en struktureret FVUlogbog. En anden gruppe på i alt 114 deltagere modtog en undervisning, der gennem brugen af det andet materiale havde fokus på processer i skrivning i hverdagstekster. En tredje gruppe på 63 deltagere fungerede som kontrolgruppe og modtog undervisning, som den enkelte FVUunderviser selv tilrettelagde.

I Arnbak \& Borstrøms undersøgelse indgik der før og efter et undervisningsforløb på 40-60 timer en afdækning af deltagernes færdigheder inden for følgende fire færdighedsområder: afkodning, læseforståelse, stavning, skrivning og ordkendskab. Endvidere blev der før og efter undervisningsforløbet indhentet oplysninger om deltagernes vurdering af deres egne færdigheder samt om tidsforbrug på læse- og skriveaktiviteter i hverdagen. Undersøgelsen viste, at deltagerne gennemsnitligt havde en beskeden, men dog signifikant fremgang inden for både afkodning, læseforståelse, stavning og skrivning. FVU-læsning er opdelt i fire successive trin, som hver især som tidligere nævnt varer 40-60 timer, men kun en lille del af undersøgelsens deltagere (17 \%) viste så stor en fremgang i læsning, stavning og skrivning efter et enkelt undervisningsforløb, at det berettigede dem til at fortsætte på næste undervisningstrin. Dette gjorde sig især gældende for deltagere med svage skriftsproglige færdigheder. Hovedparten af disse deltagere havde færdigheder i læsning, stavning og skrivning, der svarer til, hvad man har fundet for voksne ordblinde i andre undersøgelser. Undersøgelsen viste endvidere, at de tosprogede deltagere ikke havde samme udbytte af skriveundervisningen som de dansksprogede deltagere, hvilket ifølge rapportens forfattere sandsynligvis skyldtes deres ringere ordkendskab. Forfatterne til rapporten om undersø-

\footnotetext{
${ }^{73}$ Arnbak, E. \& Borstrøm, I. (2004). FVU-deltageres bevidsthed om og udbytte af lase-, staveog skriveundervisning - en afprøvning af to undervisningsmaterialer. København: Undervisningsministeriet. (http://us.uvm.dk/voksen/fvu/documents/afrpoevning undervisningsmaterialer.pdf)
} 
gelsen vurderer, at en del af de svage voksne læsere formodentlig slet ikke burde modtage FVU-undervisning, fordi tilbuddet ikke er beregnet til voksne med meget ringe skriftsproglige færdigheder og forudsætninger som fx voksne med ordblindevanskeligheder, tosprogede voksne eller voksne med generelle indlærings- og sprogvanskeligheder.

Undersøgelsen viste endvidere, at projektdeltagerne i de to særligt tilrettelagte undervisningsforløb øgede deres brug af skrivning i hverdagen i højere grad end deltagerne i kontrolgruppen. Den særligt tilrettelagte undervisning førte således tilsyneladende til, at de voksne blev motiverede til at bruge skriftsproget mere i hverdagen. Desuden viste undersøgelsen, at deltagerne i de to særligt tilrettelagte undervisningsforløb ved afslutningen havde en mere realistisk fornemmelse af deres udbytte af undervisningen end kontrolgruppens deltagere.

\section{B. Evalueringsundersøgelse af FVU}

Danmarks Evalueringsinstitut (EVA) har gennemført en evaluering af FVU i både læsning og matematik. ${ }^{74}$ Formålet med evalueringen var at vurdere svage og stærke sider ved FVU samt at vurdere, hvorvidt udmøntningen af loven lever op til lovens formål.

Der blev udvalgt ti institutioner, som udbød FVU. På disse institutioner gennemførte ledelser og undervisere selvevalueringer og afleverede selvevalueringsrapporter med beskrivelser og vurderinger af deres praksis i forhold til FVU. Evalueringsgruppen og projektgruppen besøgte de ti udbydere og mødte undervisere, deltagere, repræsentanter for eksterne samarbejdspartnere og ledelserne. Møderne blev struktureret i henhold til en generel spørgeguide, som var tilpasset den enkelte udbyders særlige forhold, og som tog udgangspunkt i udbyderens selvevalueringsrapport. Der blev endvidere som led i evalueringen gennemført en kombineret postal og telefonisk spørgeskemaundersøgelse blandt 849 personer, der havde deltaget i et FVU-forløb.

$77 \%$ af de adspurgte deltagere angav, at de var blevet enten lidt eller meget bedre til at læse, fordi de havde gået til FVU. 66 \% af de voksne, der havde deltaget i FVU, angav, at de i høj eller i nogen grad har kunnet bruge det, de har lært.

Der indgik ikke mål for deltagernes læse- og skrivefærdigheder i undersøgelsen, og den viser derfor ikke noget om, hvorvidt deltagerne objektivt målt faktisk forbedrede deres færdigheder.

Deltagerne blev spurgt om deres tilknytning til arbejdsmarkedet før deres FVU-forløb og cirka to år efter. Undersøgelsen viste, at der kun var marginale ændringer af den samlede gruppes profil. Dog var andelen af ledige faldet fra 21 til $17 \%$. Endvidere var gruppen under uddannelse vokset fra 11 til $16 \%$. Det er ikke muligt på baggrund af disse oplysnin-

\footnotetext{
${ }^{74}$ Danmarks Evalueringsinstitut (2005). Forberedende voksenundervisning. København: Danmarks Evalueringsinstitut. (http://217.61.44.102/Admin/Public/Download.aspx?file=Files/Filer/ Rapporter\%202004/Forberedende\%20voksenundervisning/FVU-rapport.pdf)
} 
ger at afgøre, hvorvidt ændringerne skyldtes deltagelse i FVU eller andre forhold.

På basis af undersøgelsen vurderer evalueringsgruppen, at FVU for nogle deltagere betyder, at deres liv ændrer sig væsentligt, og at helt nye muligheder åbner sig i forhold til såvel privatlivet som uddannelse og arbejde. Samtidig påpeger forfatterne til evalueringsrapporten dog, at FVU for en del deltagere ikke er det optimale tilbud. Således vurderes det, at mange af de tosprogede deltagere dels mangler sproglige og kulturelle forudsætninger for at deltage i holdundervisning på FVU, dels har et behov for at forbedre deres danskkundskaber, som et FVU-tilbud ikke kan opfylde. I rapporten anslås det, at mindst en tredjedel af FVUdeltagerne var tosprogede.

Ifølge rapporten var frafaldet fra virksomhedsforlagte FVU-hold markant lavere end på de „almindelige“ hold, hvor undervisningen foregik på en institution. Dette kan ifølge evalueringsgruppen skyldes flere forhold, $\mathrm{fx}$ at ledelsen på virksomhederne har en forventning om, at deltagerne gennemfører FVU-forløbet, når det ligger i arbejdstiden, og at kollegernes tilstedeværelse kan udgøre en motiverende faktor for den enkelte deltager. Endvidere fremhæves det i rapporten som en fordel, at der i den virksomhedsforlagte undervisning er mulighed for at tage udgangspunkt i virksomhedens daglige problemstillinger.

\section{Undersøgelse af erfaringerne med FVU}

En forskergruppe fra Danmarks Pædagogiske Universitet (Carter, Kjertmann, Klewe \& Larsen, 2004) har gennemført en undersøgelse med det formål at indhøste foreløbige erfaringer med undervisningen med henblik på at klarlægge behovet for eventuelle justeringer og yderligere tiltag. ${ }^{75}$

I forbindelse med undersøgelsen deltog 87 FVU-deltagere i gruppeevalueringer, mens 20 deltagere blev interviewet individuelt. Desuden blev der gennemført samtaler med en række FVU-lærere.

Forfatterne til rapporten om undersøgelsen konkluderer, at FVU i høj grad har ramt den tilsigtede målgruppe, hvad angår danske deltagere. I forhold til de tosprogede sætter forfatterne dog spørgsmålstegn ved, om FVU-læsning er det rette tilbud til de indvandrere, der tilsyneladende ikke deltager for at blive bedre til at læse, men primært for at blive bedre til at tale dansk.

\section{Undersøgelse af forventninger og oplevet udbytte af virksomheds- forlagt FVU}

Konsulentbureauet Mercuri Urval har for Nordjyllands Amt med tilskud fra Undervisningsministeriet udarbejdet en rapport, blandt andet med det formål at dokumentere effekten af FVU på virksomhederne. ${ }^{76}$ Datamate-

\footnotetext{
${ }^{75}$ Carter, J., Kjertmann, K., Klewe, L. \& Larsen, I.B. (2004). Forberedende voksenundervisning $(F V U)$ - en undersøgelse af erfaringerne med FVU. København: Danmarks Pædagogiske Universitet.

${ }^{76}$ Lund, J. \& Pedersen, L. V. (2006). Effekt af FVU \& Anbefalinger til Uddannelsesaktører på FVU-området. København: Mercuri Urval. http://us.uvm.dk/voksen/fvu/documents/kvu rapport.pdf
} 
rialet er baseret på spørgeskemaundersøgelser blandt virksomheder og deltagere i FVU. Rapporten viser, at der i overvejende grad af sammenfald mellem virksomhedernes forventninger til og oplevelse af udbyttet af FVU. Fx er der blandt virksomhedsledere høje forventninger til, at FVU vil medføre et kompetenceløft, og det opleves stort set, at disse forventninger opfyldes. Dette gælder også for de adspurgte deltagere. Der kan dog på basis af oplysningerne i rapporten om undersøgelsen ses en svag tendens til, at deltagerne på nogle områder ikke helt har fået opfyldt deres forventninger til udbyttet af FVU, fx hvad angår forventningerne om at blive bedre til deres arbejde og få bedre mulighed for at få et nyt job i virksomheden.

Rapporten om undersøgelsen er udelukkende baseret på virksomheders og FVU-deltageres udsagn vedrørende forventninger til og oplevet udbytte af FVU. Der er således ikke gennemført en undersøgelse af, hvorvidt deltagerne fx faktisk har forbedret deres kompetencer som følge af deltagelse i FVU på virksomheder.

\section{E. Evalueringsundersøgelse af FVU-projekt for medarbejdere i Greve Kommunes hjemmepleje}

I Greve Kommunes hjemmepleje blev der i 2005-2006 gennemført en række FVU-forløb for en stor gruppe medarbejdere, primært social- og sundhedshjælpere og social- og sundhedsassistenter. Undervisningsforløbene fandt sted under overskriften „Skriftlig kommunikation“ og er beskrevet og evalueret i en rapport udarbejdet af Niras-konsulenterne for Roskilde Amt. ${ }^{77}$

Projektet tog udgangspunkt $\mathrm{i}$, at der i lovgivningen stilles krav om skriftlig dokumentation inden for plejeområdet. For at sikre kontinuitet i plejen er der i forbindelse med lovgivningen på området udarbejdet en samarbejdsbog, som alle ansatte i hjemmeplejen skal bruge til at dokumentere deres observationer og handlinger og til at holde sig orienterede om de borgere, der plejes.

Projektet blev tilrettelagt således, at samtlige cirka 500 medarbejdere i kommunens hjemmepleje indledningsvis deltog i en screening. Formålet med screeningen var at identificere de medarbejdere, hvis læse- og skrivefærdigheder ikke var tilstrækkelige. Disse medarbejdere deltog efterfølgende i et forløb i FVU-læsning. Deltagelsen i screeningen og - såfremt screeningen viste et behov - deltagelsen i den efterfølgende undervisning blev af Greve Kommune gjort obligatorisk.

Undervisningen strakte sig over 40-60 timer, og arbejdet med den nævnte samarbejdsbog indgik som et væsentligt element i undervisningen. Undervisningen blev varetaget af to FVU-lærere. Begge underviserne deltog inden undervisningsforløbet i et mindre praktikforløb i hjem-

\footnotetext{
${ }^{77}$ NIRAS-konsulenterne (2006). Evaluering af kompetenceudviklingsprojekt „Skriftlig kommunikation“ for medarbejdere i Greve Kommunes Hjemmepleje. Slutevaluering. Roskilde: Roskilde Amt.
} 
meplejen for at få en større forståelse for deltagernes arbejdsfelt og ikke mindst anvendelse af samarbejdsbogen. Herudover blev retningslinjerne og procedurerne for anvendelse af samarbejdsbogen gennemgået for underviserne af uddannelseskonsulenten i Greve Kommune.

Projektet blev evalueret af et konsulentbureau på basis af blandt andet telefoniske interviews med 93 deltagere en måned efter afslutningen af deres undervisningsforløb. Endvidere blev der gennemført en rundbordssamtale med seks medarbejdere, der havde deltaget i undervisningen.

Interview-undersøgelsen viste, at $62 \%$ af deltagerne havde oplevet en fremgang generelt i forhold til deres skriftlige kompetencer. $50 \%$ af deltagerne vurderede således, at de i nogen eller i høj grad var blevet bedre til at læse, stave og skrive, mens $12 \%$ i ringe grad oplevede en fremgang.

Tilsvarende oplevede $65 \%$ af deltagerne fremgang i forhold til at kunne skrive i samarbejdsbogen. 58 \% svarede, at de i nogen eller i høj grad var blevet bedre til at skrive i samarbejdsbogen, mens $7 \%$ i ringe grad oplevede en forbedring. Af de medarbejdere, der slet ikke oplevede at være blevet bedre til at skrive i samarbejdsbogen, angav langt hovedparten som forklaring på den manglende forbedring, at de ifølge deres egen vurdering ikke havde haft problemer med at skrive i samarbejdsbogen før undervisningsforløbet.

$75 \%$ af deltagerne var enten overvejende tilfredse eller tilfredse med den måde,

som undervisningen foregik på, mens 25 \% var overvejende utilfredse eller utilfredse. I de gennemførte interviews gav cirka $70 \%$ af deltagere udtryk for, at underviseren var velforberedt, god til at undervise og tog hensyn til de enkelte deltageres behov.

Deltagerne blev bedt om at komme med forslag til, hvordan kurset kunne forbedres. De fleste forslag til en bedre undervisning omhandlede samarbejdsbogens inddragelse i undervisningen, som mange deltagere gerne så øget.

Der indgik ikke mål for deltagernes læse- og skrivefærdigheder i den ovenfor beskrevne undersøgelse, og den viser derfor ikke noget om, hvorvidt deltagerne objektivt målt faktisk forbedrede deres færdigheder. Det fremgår imidlertid af evalueringsrapporten, at Greve Kommune ved gennemgang af udvalgte samarbejdsbøger skal foretage en vurdering af, om der er sket en reel kvalitativ forbedring af anvendelsen af samarbejdsbogen. $^{78}$

\footnotetext{
${ }^{78}$ I forbindelse med det nordiske forprojekt er det forsøgt afdækket, hvorvidt en sådan gennemgang af udvalgte samarbejdsbøger faktisk er gennemført, og hvad en eventuel gennemgang viste. Det har imidlertid ikke været muligt at fremskaffe oplysninger om en sådan gennemgang.
} 


\subsubsection{Ordblindeundervisning}

\subsection{Beskrivelse af tilbud}

Ifølge den gældende bekendtgørelse om ordblindeundervisning for voksne ${ }^{79}$ er denne undervisning målrettet personer med basale vanskeligheder med at tilegne sig skriftsproget (ordblinde), der har behov for særligt tilrettelagt undervisning for at afhjælpe eller begrænse vanskelighederne og forbedre deres muligheder for at klare sig i sammenhænge, der kræver skriftsproglige færdigheder. Der skal være tale om undervisning, som ikke ydes i henhold til anden lovgivning. Undervisningens indhold skal kunne medvirke til at forbedre deltagerens mulighed for at benytte kompenserende strategier og metoder, der øger deltagerens mulighed for at fungere i beskæftigelse, uddannelse, samfundslivet og privatlivet, herunder at give deltageren mulighed for at forstå, anvende og producere skrevne tekster og at anvende relevante hjælpemidler.

Ordblindeundervisning udbydes på voksenuddannelsescentrene (VUC). Efter driftsoverenskomst med voksenuddannelsescentret kan ordblindeundervisning udbydes af en lang række forskellige institutioner inden for forskellige områder, herunder arbejdsmarkedsuddannelser, erhvervsrettede uddannelser, folkehøjskoler, folkeoplysende foreninger, daghøjskoler og sprogcentre. ${ }^{80}$

Der er fra 2007 indført en obligatorisk visitationstest ${ }^{81}$, som Undervisningsministeriet stiller til rådighed for uddannelsesinstitutionerne. I forbindelse med indstilling til ordblindeundervisning er det et krav, at denne test viser, at deltageren opfylder betingelserne for at modtage undervisning. Hvis deltageren ikke opfylder kravene og fx opnår så gode resultater på testen, at vedkommende ikke kan indstilles til ordblindeundervisning, skal deltageren vejledes om andre undervisningstilbud, fx FVU-læsning (jf. afsnit 4.2.2.1).

\subsection{Undersøgelser af effekten af deltagelse i tidligere tilbud om ordblindeundervisning}

Der blev for cirka ti år siden omtrent samtidig gennemført to effektundersøgelser af den daværende kompenserende specialundervisning for ordblinde. Disse to undersøgelser beskrives kort i det følgende.

\footnotetext{
${ }^{79}$ Bekendtgørelse om ordblindeundervisning for voksne (BEK nr 1372 af 15/12/2005).

(http://147.29.40.90/_GETDOC_/ACCN/B20050137205)

${ }^{80}$ Bekendtgørelse om ordblindeundervisning for voksne (BEK nr 1372 af 15/12/2005).

(http://147.29.40.90/_GETDOC /ACCN/B20050137205)

${ }^{81}$ Undervisningsministeriet (2006). Foreløbig vejledning om visitation til ordblindeundervisning for voksne. Indledende samtale, obligatorisk test og visitation. København: Undervisningsministeriet. (http://us.uvm.dk/voksen/fvu/documents/visitationsvejledning.doc)
} 
A. En undersøgelse af effekten af den kompenserende specialundervisning i AOF

Holders, Petersen, Borstrøm \& Elbro (1996) gennemførte en undersøgelse af voksnes udbytte af kurser afholdt af Arbejdernes Oplysningsforbund (AOF) inden for den kompenserende specialundervisning for ordblinde. ${ }^{82}$

Undersøgelsen omfattede 21 hold med i alt 102 deltagere fra hele landet. Deltagernes læse- og stavefærdigheder og deres sproglige forudsætninger blev testet ved undervisningens begyndelse og igen efter gennemsnitligt 15 undervisningsgange. Undersøgelsen viste, at deltagerne gik signifikant frem på test af læseforståelse samt læsning og stavning af nye ord (nonsensord), hvorimod der ikke kunne påvises signifikante fremgange på test af læsning og stavning af rigtige ord eller af sproglige forudsætninger. Gennemsnitligt var der tale om relativt beskedne fremgange, men $33 \%$ af deltagerne øgede deres læsehastighed markant (med mindst $20 \%$ ), og $25 \%$ gik markant frem i stavning af rigtige ord. Der blev ikke fundet signifikante sammenhænge mellem de målbare ændringer i deltagernes færdigheder og deltagernes egne vurderinger af udviklingen i deres færdigheder.

Undervisernes faglige kvalifikationer blev vurderet ved, at underviserne besvarede en bunden opgave. Undersøgelsen viste, at især undervisere med god faglig indsigt i ordblindhed havde succes med undervisningen, idet der blandt deres deltagere var lavest frafald og størst forbedring af de sproglige forudsætninger. Endvidere blev undervisernes holdninger til ordblindeundervisning afdækket ved hjælp af et spørgeskema. Det viste sig, at der var signifikante sammenhænge mellem undervisernes holdninger og deltagernes udbytte af undervisningen. Fx hang en høj prioritering af arbejdet med sproglige forudsætninger, strategier i læsning og brug af realistiske tekster ( $\mathrm{f} x$ deltagernes egne tekster) sammen med et relativt stort deltagerudbytte. I modsætning hertil kunne der ikke påvises nogen sammenhænge mellem høj prioritering af fx sansemotorisk udvikling og deltagernes faktiske eller oplevede udbyttet af undervisningen.

\section{B. En undersøgelse af effekten af den kompenserende specialundervisning} i Århus Amt

Lau, Holst, Brøcker \& Klausen (1995) gennemførte en undersøgelse af voksnes udbytte af den kompenserende specialundervisning for læse- og stavehandicappede i Århus Amt. ${ }^{83} 468$ deltagere gennemførte test af deres færdigheder i læsning og stavning ved undervisningens begyndelse. Af dem gennemførte 240 de samme test efter gennemsnitligt 42 lektioner. Undersøgelsen viste, at $34 \%$ af deltagerne øgede deres læsehastighed

\footnotetext{
${ }^{82}$ Holders, B., Petersen, D.K., Borstrøm, I. \& Elbro, C. (1996). Undervisning af voksne ordblinde. En undersøgelse af undervisningseffekt og lærerkvalifikationer i ordblindeundervisningen i AOF. København: Forlaget Skolepsykologi.

${ }^{83}$ Lau, J., Holst, C., Brøcker, A. \& Klausen, A.B. (1995). Nytter det noget? - om den kompenserende specialundervisning for læse- og stavehandicappede i Århus Amt. København: Danmarks Pædagogiske Institut.
} 
markant (med mindst $20 \%$ ), og at $20 \%$ gik markant frem i stavning. Disse tal svarer omtrent til resultaterne af den ovenfor beskrevne undersøgelse af Holders et al. (1996).

Undersøgelsen viste endvidere, at der var en sammenhæng mellem elevernes udbytte og undervisningens intensitet. Mindst fire timers undervisning om ugen og flere end 40 lektioner i alt gav det største udbytte. Undersøgelsen fandt ingen sammenhæng mellem lærernes vurdering af deltagernes udbytte og deltagernes faktiske udbytte, som det blev målt ved hjælp af testene.

4.2.2.3 Igangværende forsøg med etablering af informations- og undervisningscentre for ordblinde på arbejdspladser i Sønderjylland

Som et eksempel på et særligt initiativ for ordblinde kan nævnes et igangværende projekt, som gennemføres af VUC Sønderjylland i samarbejde med Arbejdsformidlingen (AF) Sønderjylland og fire store sønderjyske virksomheder (Danfoss, Sauer-Danfoss, Hartmann og Hydro). ${ }^{84}$ Målet for projektet er at opkvalificere 100 ordblinde, der er ansat på virksomheder i lokalområdet.

På de involverede virksomheder er der oprettet en række informationscentre i kantinerne. Her kan medarbejderne få svar på spørgsmål af en ordblindeunderviser. De kan også få demonstreret tekniske hjælpemidler for ordblinde og få lavet en foreløbig test, som kan give en indikation for, hvorvidt medarbejderen har brug for at komme til en mere grundig test for ordblindhed. Ordblinde medarbejdere gives tilbud om at deltage i kompenserende specialundervisning i arbejdstiden på arbejdspladsen. Gennem Arbejdsformidlingen har de endvidere mulighed for at få bevilliget IT-hjælpemidler (en computer, en scanner og en C-pen).

Som led i projektet udnævnes der endvidere ordblindeambassadører på de fire virksomheder. På de tre af virksomhederne har man valgt at udpege ordblinde medarbejdere som ambassadører.

Ambassadørerne skal være med til at opfange de medarbejdere, som kan være ordblinde, udbrede budskabet om undervisningstilbuddet for ordblinde og henvise til infocentrene.

En stor del af de personer, som henvender sig til de oprettede centre, kan med det samme afvises som „ikke ordblinde“, men er læsesvage. For disse og øvrige medarbejdere er der blevet etableret undervisning i FVUlæsning. ${ }^{85}$

Der gennemføres en løbende evaluering af projektet. Evalueringen foretages både som en subjektiv vurdering af metoder og forløb (spørgeskemaer eller interview blandt medarbejdere og virksomhedsledere) og som en før/efter test blandt kursisterne på færdigheder og viden. Projektet

\footnotetext{
${ }^{84}$ Bernhoft, A. (2006). Ordblinde får undervisning på arbejdet. LVUfagbladet 8, 10-11.

${ }^{85}$ Viig, M. (2006). Info-centre for ordblinde. Status set i forhold til overførsel af midler fra 2005 til 2006. Haderslev: VUC Sønderjylland.
} 
strækker sig fra 2005 frem til 2008 og er finansieret af Arbejdsmarkedsstyrelsen. ${ }^{86}$

\subsubsection{Private initiativer}

Når der udbydes læse- og skriveundervisning på private danske virksomheder, foregår dette oftest inden for rammerne af bekendtgørelserne om FVU eller ordblindeundervisning (jf. eksemplerne ovenfor). Det kan dog nævnes, at fx virksomheden TDC i samarbejde med det private firma Ordkløveriet tilbyder egne læse-skrivekurser for medarbejderne. ${ }^{87}$ Endvidere har virksomheden Novo Nordisk tidligere taget initiativ til at gennemføre egne læsekurser for medarbejderne (jf. afsnit 4.2.2.4.1 nedenfor).

\subsection{Evaluering af lcesekurser på Novo Nordisk}

For at styrke medarbejdernes generelle læsefærdigheder tog virksomheden Novo Nordisk i 1990'erne initiativ til oprettelse af en række læsekurser, som er blevet beskrevet og evalueret i en projektrapport. ${ }^{88}$ Kurserne blev gennemført i samarbejde med AOF og Danmarks Pædagogiske Institut. 2201 medarbejdere blev screenet med nogle almene læse- og skriveprøver samt en specielt udviklet prøve, der skulle afdække medarbejdernes færdigheder i at forstå virksomhedens skriftlige instruktioner. I alt 176 medarbejdere deltog i et kursus på 90 lektioner. Langt hovedparten af kursisterne havde enten afgangseksamen fra folkeskolen som det højeste uddannelsesniveau eller ingen afsluttende eksamen. Undervisningen fandt sted på virksomhedens fabrikker og havde som mål, at kursisterne øgede deres læseforståelse og læsehastighed og blev bedre til at formulere sig skriftligt. Læsning af skøn- og faglitteratur samt avis- og ugebladsartikler indgik i en stor del af undervisningstiden. Det fremgår ikke af projektrapporten, hvorvidt der blev anvendt tekster, der direkte var relaterede til kursisternes arbejde på Novo Nordisk.

Efter undervisningsforløbet blev deltagerne bedt om at kommentere undervisningen. $46 \%$ af kursisterne vurderede, at kurset var meget godt, mens 53 \% vurderede, at det var ret godt eller godt. Kun to af kursisterne mente, at kurset ikke havde været så godt.

Kursisternes læse- og skrivefærdigheder blev ikke afdækket efter undervisningsforløbet, og undersøgelsen viser derfor ikke noget om, hvorvidt deltagerne objektivt målt faktisk forbedrede deres færdigheder.

\subsubsection{IT-hjælpemidler til læsehandicappede voksne i arbejde}

Der findes forskellige teknologiske hjælpemidler, som kan støtte læsehandicappede voksne i arbejdssammenhæng. For en nærmere beskrivelse

\footnotetext{
${ }^{86}$ VUC Sønderjylland (2005). Ansøgning om midler til infocentre for ordblinde. Haderslev: VUC Sønderjylland.

${ }^{87}$ Jf. Ordkløveriets website: http://www.ordkloeveriet.dk

${ }^{88}$ Lau, J. \& Sommer, M. (1999). Voksne leeser på arbejdspladsen. København: Danmarks Pædagogiske Institut.
} 
af de gældende lovgivningsmæssige rammer for at få bevilliget teknologisk læse- og skrivestøtte i arbejdslivet i Danmark henvises der til publikationen „Hjæelpemidler til mennesker med ordblindhed““ ${ }^{89}$

Endvidere kan der henvises til en nyligt udgivet nordisk DVD, som indeholder beskrivelser af og eksempler på, hvordan danskere i arbejde kan støttes af IT-hjælpemidler ${ }^{90}$. (DVD-udgivelsen beskrives nærmere i afsnit 4.7 om fælles-nordiske tiltag).

4.2.2.6 Igangværende undersøgelse af effekt af voksne ordblindes brug af IT-hjælpemidler (Projekt PC-læsning)

Det igangværende danske Projekt PC-lcesning vil involvere i alt cirka 150 voksne ordblinde, der modtager undervisning i brug af IT-hjælpemidler, dvs. pc'er med højtlæsningsprogram og syntetisk tale. Hjælpemidlerne kan være bevilget af amter, kommuner, arbejdsformidlingen eller SUstyrelsen. Projektets mål er at evaluere effekten af hjælpemidlerne og afklare hos hvilke typer af ordblinde, effekten er størst med henblik på fastholdelse og øgede muligheder på arbejdsmarkedet. I forbindelse med projektet er der udviklet en særlig pc-læsetest til evaluering af læseforståelsen, når en tekst oplæses med syntetisk tale for ordblinde. ${ }^{91}$ Deltagerne i undersøgelsen testes og/eller interviewes tre gange i løbet af projektperioden: ved undervisningens start, efter endt undervisning i brug af IThjælpemidler og igen et år efter. ${ }^{92}$

Projektet er finansieret af Arbejdsmarkedsstyrelsen.

4.2.2.7 Igangværende forskningsprojekt vedrørende mobil e-læring for ordblinde (Projekt MELFO)

Ifølge beskrivelsen af det igangværende Projekt MELFO er formålet at udvikle et hjælpemiddel og mobil e-læring til læsesvage og ordblinde til håndholdt computer (PDA). ${ }^{93}$ De læsesvage og ordblinde vil med PDA'en kunne få umiddelbar hjælp til læsning i enhver situation. PDA'en kan tage billeder af tekster (skilte, instruktioner el.lign.), og disse tekster kan derefter blive læst højt for brugeren ved hjælp af talesyntese. Der vil blive arbejdet med at lave en ikonisk baseret brugergrænseflade således at programmerne ikke kræver læsekundskaber.

På Københavns Universitet udvikler Center for Læseforskning i samarbejde med Center for Sprogteknologi og Film- og Medievidenskab en e-læringskomponent med morfembaseret læsetræning og hjælp til styr-

\footnotetext{
${ }^{89}$ Arendal, E. (2006). Hjælpemidler til mennesker med ordblindhed. Århus: Hjælpemiddelinstituttet.

${ }^{90}$ NAV NONITE - Nordnorsk IKT-senter (2006). Nordisk informations DVD om teknologisk læese- og skrivestøtte i arbejdslivet. Bodø: NAV NONITE - Nordnorsk IKT-senter.

${ }^{91}$ Arendal (2005). Pc-læsningsprojekt for ordblinde. Hjælpemiddelinstituttets Nyhedsbrev (september 2005). (http://www.hmi.dk/index.asp?search=PC-læsning\&id=772\#711)

${ }^{92}$ Arendal (2005). PC-læsning. Ordblindhed og hjælpemidler. Projektbeskrivelse. Århus: Hjælpemiddelinstituttet.

${ }^{93}$ Jf. beskrivelse af Projekt MELFO på Center for Læseforsknings website http://www.cphling.dk/laes/

under linket mobil it som læsestøtte.
} 
kelse af det faglige ordforråd. Endvidere vil der blive set på, hvordan computerspil og visualisering kan indgå i og lette læsetræningen.

Der skal testes for hjælpemiddelets (oplæsningskomponentens) umiddelbare effekt ved læsningen af faglige tekster. Derudover testes effekten af den morfologisk baserede undervisning sammenlignet med den traditionelle læseundervisning for voksne.

I første fase af projektet målrettes den kombinerede læsehjælp og elæring mod byggebranchen. Et vigtigt kriterium i MELFO-projektet er dog at gøre det muligt - i et mere langsigtet perspektiv - at kunne genbruge de opnåede resultater og erfaringer, således at de kan genanvendes inden for andre brancher og sprog.

Konsortiet bag Projekt MELFO er Københavns Universitets Humanistiske Fakultet, Statens Byggeforskningsinstitut samt virksomhederne Motto S.A., Sensus ApS, Hewlett-Packard og Motorola. ${ }^{94}$

\subsubsection{Støtteforanstaltninger i uddannelsessammenhæenge}

4.2.3.1 Specialpædagogisk støtte (SPS) for deltagere i erhvervsuddannelser m.m.

Specialpædagogisk støtte (SPS) kan tildeles deltagere i blandt andet erhvervsuddannelser, erhvervsgymnasiale uddannelser og landbrugets grunduddannelse (uddannelsen til faglært landmand). SPS skal sikre, at elever og studerende med en fysisk eller psykisk funktionsnedsættelse eller sidestillede vanskeligheder kan gennemføre en uddannelse på lige fod med andre. ${ }^{95}$ Dokumenteret ordblindhed berettiger til SPS.

Deltagere kan på baggrund af en faglig vurdering af deres behov tildeles støtte som $\mathrm{fx}$ :

- Særligt tilrettelagte undervisningsforløb

- Hjælpemidler og instruktion i brug heraf

- Særligt udformede undervisningsmaterialer

- Personlig assistance og sekretærhjælp

- Særlige vilkår for og arbejdsformer under prøver og eksaminer

Deltagere på erhvervsuddannelser skal søge om SPS på deres uddannelsessted. Uddannelsesstederne træffer afgørelse i sagen og søger om refusion af deres udgifter hos SU-styrelsen. Uddannelsesstederne sørger for at skaffe den tildelte støtte.

Styrelsen for statens uddannelsesstøtte administrerer SPS-ordningen. Styrelsen er i gang med at udvikle et system til screening for ordblindhed. Formålet med screeningssystemet er at skabe en lettilgængelig dokumen-

\footnotetext{
${ }^{94}$ Jf. pressemeddelelse fra Københavns Universitets Humanistiske Fakultet 1. maj 2006: Elcering for ordblinde. (http://www1.hum.ku.dk/presserum/pressemeddelelser/2006/melfo/)

${ }^{95} \mathrm{Jf}$. SU-styrelsens portal om specialpædagogisk støtte, specielt afsnittet om erhvervsuddannelser (http://www.spsu.dk/eud/index.html)
} 
tationsform for ordblindhed, i første omgang til anvendelse på erhvervsuddannelsesområdet. ${ }^{96}$

4.2.3.2 Hjælpemidler m.m. for deltagere i arbejdsmarkedsuddannelser (AMU)

De enkelte AMU-centre kan søge om at få særligt udstyr eller hjælpemidler stillet gratis til rådighed for en deltager med et særligt behov. Dette gælder blandt andet for ordblinde deltagere. Udstyret skal være nødvendigt for at deltageren kan gennemføre uddannelsen. AMU-Hjælpemiddelservice stiller hjælpemidler til rådighed for deltagere, som har brug for dette for at kunne gennemføre kursusforløbet på lige vilkår med andre deltagere i AMU. Det kan fx dreje sig om pc, skanner og program til oplæsning af tekst. ${ }^{97}$

AMU hjælpemiddelservice sørger i en vis udstrækning også for elektroniske versioner eller lydudgaver af de undervisningsbøger, der bruges på kurserne. I nogle tilfælde må kursisten og underviseren selv rekvirere eller udarbejde materialet. I de senere år er der udgivet en række audiovisuelle materialer fra uddannelsesudvalgene, som kan være et alternativ til de skriftbaserede papirudgaver af undervisningsbøgerne. ${ }^{98}$

\subsubsection{Arbejdsmarkedsuddannelsen „Faglig læsning og skrivning“}

AMU-systemet omfatter arbejdsmarkedsuddannelsen „Faglig læsning og skrivning“. Denne uddannelse gennemføres normalt i kombination med en faglig arbejdsmarkedsuddannelse med henblik på at styrke deltagernes muligheder for at gennemføre denne. Formålet med uddannelsen er, at deltageren øger sit udbytte af faglig læsning i forbindelse med såvel relevante jobfunktioner og de aktuelle faglige uddannelser. Formålet er endvidere, at deltageren øger sine forudsætninger for at kommunikere skriftligt i såvel jobfunktioner som i de aktuelle faglige uddannelser. ${ }^{99}$

Dette tilbud anvendes ifølge Trepartsudvalget (2006) kun i meget begrænset omfang. ${ }^{100}$

\footnotetext{
${ }^{96}$ Boesen, O. \& Krohn-Rasmussen, J. (2006). Ordblinde efteruddanner sig som aldrig før. Nyt om ordblindhed, nr. 46. (http://www.dvo.dk/index.php?id=164).

${ }^{97} \mathrm{Jf}$. Undervisningsministeriets portal „,Tilgcengelighed til uddannelse“, specielt afsnittet „Støtte under arbejdsmarkedsuddannelser" (http://www.tilgaengelighed.emu.dk/tilgaengelighed/erhvervamuudd/spamu.html)

${ }^{98}$ Jf. Undervisningsministeriets portal „,Tilgcengelighed til uddannelse“, specielt afsnittet „Støtte under arbejdsmarkedsuddannelser

(http://www.tilgaengelighed.emu.dk/tilgaengelighed/erhvervamuudd/spamu.html)

${ }^{99}$ Jf. beskrivelse af Arbejdsmarkedsuddannelsen „Faglig lessning og skrivning“ i Statens database med oplysninger om voksenuddannelse i Danmark. (http://www.vidar.dk/vidar/vidpubre.nsf/0/CEB740ACAC612C08C12571DC00386ADE?OpenDocu ment)

${ }^{100}$ Trepartsudvalget (2006). Livslang opkvalificering og uddannelse for alle på arbejdsmarkedet. Bind 1: Den fremtidige voksen- og efteruddannelsesindsats. København: Finansministeriet. (s. 127) (http://www.fm.dk/1024/visPublikationesForside.asp?artikelID=8112)
} 
4.2.3.4 Igangværende forsøg med ord- og regneværksteder for deltagere i erhvervsrettet voksen- og efteruddannelse ${ }^{101}$

Der gennemføres p.t. forsøg med ord- og regneværksteder på en række erhvervsrettede uddannelsesinstitutioner. Ord- og regneværkstederne retter sig imod kortuddannede voksne, som deltager i erhvervsrettet voksen- og efteruddannelse, herunder arbejdsmarkedsuddannelse (AMU), grunduddannelse for voksne (GVU) og voksenerhvervsuddannelse (VEUD). Forsøget er iværksat med det formål at forbedre mulighederne for, at kortuddannede deltagere i erhvervsrettet voksen- og efteruddannelse kan nå målene for deres uddannelse. Ord- og regneværkstedernes aktiviteter består af følgende:

Et tilbud om individuelt tilpasset supplerende undervisning i læsning, skrivning, regning og matematik, der er nødvendigt for, at deltageren kan gennemføre sin erhvervsrettede efteruddannelse. Den supplerende undervisning i værkstederne tilrettelægges individuelt og i tilknytning til undervisningen på den erhvervsrettede efteruddannelse og har deltagerens gennemførelse af den pågældendes erhvervsrettede efteruddannelse som formål.

Et tilbud om vejledning af uddannelsesinstitutionens undervisere på de erhvervsrettede voksen- og efteruddannelser om:

- metoder til hurtig identifikation af uddannelsesdeltagere med behov for værkstedets undervisningstilbud

- metoder til udarbejdelse af undervisningsmaterialer, der også er egnede til deltagere med læse-, skrive-, regne- og matematikvanskeligheder

- $\quad$ valg af undervisningsmetoder, der er egnede til deltagere med læse-, skrive-, regne- og matematikvanskeligheder.

Undervisningsmaterialerne vil overvejende være materialer fra undervisningen på deltagerens erhvervsrettede efteruddannelse (manualer, tegninger, CD-rom-baserede opgaver og øvelser m.v.).

Initiativet blev igangsat af Undervisningsministeriet i sommeren 2005 og kører som forsøgsordning frem til år 2008. Der gennemføres evaluering af forsøget. Således skal de uddannelsesinstitutioner, som indgår i forsøget, foretage selvevaluering og aflægge rapport til Undervisningsministeriet. Endvidere iværksætter Undervisningsministeriet en samlet evaluering af forsøgene med ord- og regneværksteder midtvejs i og ved afslutningen af forsøgsperioden. Midtvejs- og slutevalueringerne gennemføres af Danmarks Evaluerings-institut og skal blandt andet dokumentere, om værkstedsforsøgene har haft den tilsigtede effekt i henhold til formålet med værkstederne, herunder sammenhængen mellem værkstedernes aktiviteter og

\footnotetext{
${ }^{101}$ Undervisningsministeriet (2006). Fakta om forsøg med etablering af ord- og regneværksteder for deltagere i erhvervsrettet voksen- og efteruddannelse på erhvervsrettede uddannelsesinstitutioner. København: Undervisningsministeriet. (http://us.uvm.dk/amu/fou/tup/documents/Ordogregnevaerkstederforkortudd.udmeldingstekst 000.pdf)
} 
den opnåede effekt på målgruppens gennemførelse (at flere gennemfører og/eller med større udbytte) af deres erhvervsrettede efteruddannelse. ${ }^{102}$

4.2.3.5 Kommende tilbud om testning af læsefærdigheder på arbejdsmarkedsuddannelser

Fra 2. halvdel af 2007 indføres et tilbud til deltagere i arbejdsmarkedsuddannelser (AMU) om testning af læse- og regnefærdigheder. Undervisningsministeriet har igangsat udvikling af nye test, som kan indgå i dette tilbud. ${ }^{103}$

\subsubsection{Scerlige undervisningstilbud for indvandrere m.fl.}

\subsubsection{Danskuddannelse for voksne udlændinge}

Udlændinge, der er fyldt 18 år og har opholdstilladelse i Danmark eller efter den gældende lovgivning har ret til at opholde sig i Danmark uden opholdstilladelse, gives tilbud om danskuddannelse. Tilbuddet omfatter en af de følgende tre danskuddannelser: Danskuddannelse 1, Danskuddannelse 2 og Danskuddannelse 3. Danskuddannelse 1 tilrettelægges for kursister med ingen eller ringe skolebaggrund, som ikke har lært at læse og skrive på deres modersmål.

Danskuddannelse 2 tilrettelægges for kursister, som normalt har en kort skole- og uddannelsesbaggrund fra hjemlandet og må forventes at have en forholdsvis langsom indlæring af dansk som andetsprog. Danskuddannelse 3 tilrettelægges for kursister, som normalt har en mellemlang eller lang skole- og uddannelsesbaggrund fra hjemlandet og må forventes at have en forholdsvis hurtig indlæring af dansk som andetsprog. ${ }^{104}$ For en nærmere beskrivelse af dette generelle tilbud om danskundervisning for udlændinge henvises der til informationer på Integrationsministeriets website. $^{105}$

4.2.4.2 Særlige tiltag for tosprogede på erhvervsrettede uddannelser Inden for arbejdsmarkedsuddannelserne (AMU) findes særlige tilbud i form af:

- arbejdsmarkedsuddannelser målrettet flygtninge og indvandrere, som fx undervisning i dansk som andetsprog

\footnotetext{
${ }^{102}$ Undervisningsministeriet (2006). Fakta om forsøg med etablering af ord- og regneværksteder for deltagere i erhvervsrettet voksen- og efteruddannelse på erhvervsrettede uddannelsesinstitutioner. København: Undervisningsministeriet. (http://us.uvm.dk/amu/fou/tup/documents/Ordogregnevaerkstederforkortudd.udmeldingstekst_000.pdf )

${ }^{103} \mathrm{Jf}$. meddelelse på Undervisningsministeriets elektroniske opslagstavle for FVU 7. marts 2007. (http://us.uvm.dk/voksen/fvu/opslagstavlen.htm?menuid=350525)

${ }^{104}$ Bekendtgørelse af lov om danskuddannelse til voksne udlændinge m.fl. (LBK nr 259 af 18/03/2006). (http://147.29.40.91/_GETDOCM_/ACCN/A20060025929-REGL)

${ }^{105}$ http://www.nyidanmark.dk/da-DK/
} 
- særlige uddannelsesforløb for flygtninge og indvandrere, hvor en eller flere arbejdsmarkedsuddannelser kan kombineres med undervisning i dansk som andetsprog. ${ }^{106}$

Ansøgere med dansk som andetsprog kan blive pålagt at gennemføre en sprogtest forud for optagelse til arbejdsmarkedsuddannelse. ${ }^{107}$ Undervisningsministeriet har i 2006 udgivet et inspirationsmateriale til sprogtest af personer med dansk som andetsprog ved optagelse på arbejdsmarkedsuddannelse (AMU). ${ }^{108}$ Det er ikke obligatorisk at benytte dette materiale. Sprogtesten tager udgangspunkt i de sproglige krav i den uddannelse, som personen søger optagelse på og skal kunne bruges til at afgøre, om

- testpersonen har så gode dansksproglige kompetencer, at han/hun kan deltage i en almindelig arbejdsmarkedsuddannelse på linje med andre, som opfylder forudsætningerne herfor,

- testpersonen har dansksproglige kompetencer på et niveau, som betyder, at det vil være hensigtsmæssigt, at han/hun optages på et særligt forløb for flygtninge og indvandrere, der inkluderer undervisning i dansk som andetsprog,

- testpersonen har utilstrækkelige dansksproglige kompetencer til at følge med i et særligt forløb for flygtninge og indvandrere og derfor må anbefales at forsøge noget andet, som modsvarer hans/hendes aktuelle dansksproglige kompetencer.

I sprogtesten vurderes følgende sproglige elementer:

- ordforråd

- læseforståelse

- lytteforståelse

- samtalefærdighed

- skrivefærdighed

- kommunikationsstrategier.

4.2.4.3 Vurdering af særlige tiltag for tosprogede på erhvervsrettede uddannelser

Lund, Bertelsen \& Sørensen (2006) har på baggrund af blandt andet observationer af undervisning og eksaminer, interviews og analyser af anvendte skriftlige materialer gennemført en undersøgelse af kravene til

\footnotetext{
${ }^{106}$ Undervisningsministeriet (2006). Tab ikke guldet på gulvet. København: Undervisningsministeriet. (http://pub.uvm.dk/2006/guldet/)

${ }^{107}$ Bekendtgørelse om fælles kompetencebeskrivelser for erhvervsrettet voksen- og efteruddannelse og om arbejdsmarkedsuddannelser (BEK nr. 802 af 22/09/2003).

${ }^{108}$ Undervisningsministeriet (2006). Sprogtest i AMU. Inspirationsmateriale til sprogtest af personer med dansk som andetsprog ved optagelse på arbejdsmarkedsuddannelse. København: Undervisningsministeriets håndbogsserie nr. 14. (http://pub.uvm.dk/2006/sprogtest/index.html)
} 
mundtlige og skriftsproglige færdigheder i udvalgte erhvervsuddannelser (EUD) og arbejdsmarkedsuddannelser (AMU). ${ }^{109}$

Undersøgelsen viser, at der indgår omfattende krav til læsning og skrivning, og at kursister fra DU2 ikke kan læse og skrive på det niveau, der lægges op til på EUD og AMU. Det påvises, at der ikke er lagt op til så højt et niveau af læsning, skrivning og ordkendskab i undervisningen og prøverne på sprogcentrene på DU2, som ellers sigter mod at give personer med kort uddannelsesbaggrund et niveau af dansk, der kan kvalificere dem til at gå i gang med en erhvervsuddannelse. Resultaterne af undersøgelsen er nærmere beskrevet i afsnit 3.2.4.1.

De undersøgte uddannelser tog på forskellig vis særlige hensyn til kursister med dansk som andetsprog: Supplerende danskundervisning for voksne med dansk som andetsprog og ekstra tid til gennemgang af det faglige stof. Det er undersøgelsens konklusion, at sådanne tiltag er absolut nødvendige, idet det fx ikke kan forventes, at de tosprogede deltagere kan tilegne $\mathrm{fx}$ grundbogsmaterialet på egen hånd. Flere af de observerede særlige tiltag for tosprogede på de undersøgte uddannelser kritiseres i rapporten for ikke i tilstrækkelig grad at være forankrede i uddannelsernes faglige kontekst. Forfatterne anbefaler blandt andet, at lærerne på AMU og EUD opkvalificeres i form af blandt andet kurser med fokus på samspillet mellem undervisningen i dansk som andetsprog og den faglige undervisning.

\subsection{Norge}

\subsubsection{Sammenfatning vedrørende norske tilbud og tiltag}

Der eksisterer i det norske offentlige system endnu ikke noget specifikt tilbud for voksne inden for grundlæggende læsning og skrivning svarende til fx den Forberedende Voksenundervisning i Danmark (jf. afsnit 4.3.2.1.). Læringscentret Vox har imidlertid i 2006 fået til opgave at udvikle forslag til en beskrivelse af nationale kompetencemål for grundlæggende færdigheder med standarder for, hvad voksne skal kunne på forskellige niveauer. Dette udviklingsarbejde kan komme til at danne grundlag for et kommende nationalt system til forbedring af voksnes grundlæggende færdigheder.

I privat regi har Oplysningsforbundet AOF udviklet et særligt kursusprogram i læsning og skrivning, som udbydes i en række lokalafdelinger (jf. 4.3.2.2.). Der er gennemført en spørgeundersøgelse blandt voksne, som havde deltaget i et eller flere af AOF's kurser. Undersøgelsen viste, at langt hovedparten af deltagerne oplevede at have fået forbedret deres

\footnotetext{
${ }^{109}$ Lund, K., Bertelsen, E. \& Sørensen, M.S. (2006). Muligheder og barrierer - en undersøgelse af overgangen mellem sprogcentre og erhvervsrettede uddannelser. København: Ministeriet for Flygtninge, Indvandrere og Integration.
} 
færdigheder gennem kurset. I undersøgelsen indgik imidlertid ingen mål for deltagernes læse- og skrivefærdigheder, og den viser derfor ikke noget om, hvorvidt deltagerne objektivt målt faktisk forbedrede disse færdigheder.

Den norske regering har i 2006 igangsat det såkaldte Program for basiskompetanse i arbeidslivet (BKA), som yder økonomisk støtte til undervisning i grundlæggende læsning, skrivning, regning og IT på virksomheder (jf. 4.3.2.3.). Der er rapporteret erfaringer fra tidligere projekter med læse- og skriveundervisning på virksomheder, men der er ikke fundet nogen større, systematiske undersøgelser af, om en given undervisning har haft en målbar effekt på deltagernes faktiske færdigheder i læsning og skrivning eller relaterede færdigheder (jf. 4.3.2.4).

Inden for den „videregående opplæring“ findes der forskellige støtteforanstaltninger for deltagere med læse- og skrivevanskeligheder, men indsatsen varierer tilsyneladende betydeligt mellem de forskellige amtskommuner (jf. 4.3.3.2).

\subsubsection{Tilbud og tiltag i arbejds- og fritidssammenhæenge}

\subsubsection{Tilbud inden for „grunnskoleopplæring“}

\subsection{Beskrivelse af rammer}

I Norge har voksne ifølge „Opplæringsloven“ ret til grundskoleundervisning (norsk: grunnskoleopplæring), hvis de har behov for en sådan undervisning. Undervisningen skal tilpasses i forhold til den enkeltes behov. ${ }^{110}$ Læse- og skriveundervisning kan ifølge læringscentret Vox defineres som en del af den ret, som voksne ifølge Opplæringsloven har til grundskoleundervisning og undervisning, som er tilpasset den enkeltes behov. ${ }^{111}$ Kommunerne har ansvaret for grundskoleundervisningen, herunder for at foretage en vurdering af den enkelte voksnes behov for undervisning. ${ }^{112}$

Voksne, som ikke har eller ikke kan få udbytte af det ordinære undervisningstilbud for voksne, har ret til specialundervisning. ${ }^{113}$ Førend der bevilliges specialundervisning, skal der foreligge en sagkyndig vurdering af personens særlige behov. ${ }^{114}$

\footnotetext{
$110 \S 4 \mathrm{~A}-1$ i „Lov om grunnskolen og den videregående opplæring (opplæringsloven)“. (http://www.lovdata.no/all/nl-19980717-061.html)

${ }^{111}$ Haugerud, V. (2006). BASIS! Voksnes læring 2006 - tilstand, utfordringer og anbefalinger (pp. 42-43). Oslo: Vox.

${ }^{112}$ Haugerud, V. (2006). BASIS! Voksnes læring 2006 - tilstand, utfordringer og anbefalinger (pp. 8-10). Oslo: Vox.

${ }^{113} \S$ 4A-2 i „Lov om grunnskolen og den videregående opplæring (opplæringsloven)“

${ }^{114}$ § 4A-3 i „Lov om grunnskolen og den videregående opplæring (opplæringsloven)“
} 


\subsection{Beskrivelse af praksis}

Læringscentret Vox har i 2004 gennem en spørgeskemaundersøgelse indhentet data fra 112 norske kommuner med henblik på at afdække kommunernes organisering af grundskoleundervisningen for voksne. ${ }^{115}$ Undersøgelsen viste, at kommunernes tilbud og tiltag på dette område var meget forskellige. Således oplyste kun lidt over halvdelen af kommunerne i undersøgelsen, at de gennemførte en samtale for at afdække behovet hos de voksne, som søger om at deltage i grundskoleundervisning. 5,2 \% af kommunerne oplyste, at de testede alle ansøgere med norsk som modersmål for læse- og skrivevanskeligheder, mens 53, 2 \% af kommunerne oplyste, at de testede „efter behov“.

I Vox’ evalueringsrapport „BASIS! “ konkluderes det, at voksne i Norge har klare rettigheder til „grunnskoleopplæring“, men at specifik undervisning i grundlæggende læsning, skrivning og regning kun sjældent bliver tilbudt. Landet har endnu ikke noget offentligt system til at hæve disse færdigheder blandt voksne, og der findes ingen fælles standarder, læreplaner eller metodiske vejledninger inden for området. Vox har imidlertid fået til opgave at udvikle forslag til en beskrivelse af nationale kompetencemål for grundlæggende færdigheder med standarder for, hvad voksne skal kunne på forskellige niveauer. Dette udviklingsarbejde kan komme til at danne grundlag for et kommende nationalt system til forbedring af voksnes grundlæggende færdigheder. ${ }^{116}$

\subsubsection{Tilbud om læse- og skriveundervisning i AOF’s regi}

\subsection{Beskrivelse af tilbud}

I Norge er AOF (Arbeidernes Opplysningsforbund) en central aktør, hvad angår kurser i læsning og skrivning for voksne med vanskeligheder på dette område. AOF har siden 1998 arrangeret sådanne læse- og skrivekurser. Deltagerne rekrutteres dels gennem arbejdsformidlingen, dels gennem annoncering og dels gennem samarbejde med virksomheder. Lokale AOF-afdelinger kan tilbyde afdækning af læse- og skrivefærdigheder og særligt tilrettelagte kurser både for den enkelte, for organisationer og for virksomheder. ${ }^{117}$

AOF har udviklet et kursusprogram bestående af tre trin, hvor hvert trin strækker sig over 102 timer. Dette program benyttes som udgangspunkt i de fleste AOF-afdelinger, som tilbyder læse- og skriveundervisning. Varigheden og indholdet af kurserne kan tilpasses i forhold til den enkelte gruppe af kursister. Kurserne omhandler hovedsageligt følgende emneområder:

\footnotetext{
${ }^{115}$ Haugerud, V., Røstad, S. \& Stubbe, T.A. (2006): Grunnskoleopplaring for voksne. Oslo: Vox.

${ }^{116}$ Haugerud, V. (2006). BASIS! Voksnes læring 2006 - tilstand, utfordringer og anbefalinger (pp. 42-50). Oslo: Vox.

${ }^{117}$ AOF's website http://www.aof.no
} 
- Kendskab til læring, sanseprocesser, koncentration, motivation og selvtillid

- Arbejde med læse- og skriveteknikker, studieteknik, retskrivning, opslagsværker, grammatik og tekstproduktion.

- Brug af PC

- Træning med PC-baserede skrive- og læsetræningsprogrammer og øvelser. ${ }^{118}$

I afsnit 5.3 i denne rapport beskrives der et konkret eksempel på et læseskrivekursus i AOF-regi.

\subsection{Efterundersøgelse af deltagere i AOF's lase- og skrivekurser}

Forskningsstiftelsen Fafo har gennemført en landsdækkende spørgeundersøgelse blandt 101 voksne, som havde deltaget i et eller flere af AOF’s læse- og skrivekurser (Solheim \& Ytrehus, 2005). ${ }^{119}$

$12 \%$ af deltagerne havde gennemført de pågældende AOF-læse- og skrivekurser på deres arbejdsplads, mens de øvrige 88 \% havde deltaget i kurset uden for arbejdssammenhæng.

$47 \%$ af deltagerne havde en erhvervsfaglig uddannelse, mens $37 \%$ havde grundskole som højeste uddannelsesniveau.

Cirka $22 \%$ af deltagerne havde fået kendskab til kurset gennem aviser eller massemedier, cirka $18 \%$ gennem arbejdskontoret, $14 \%$ gennem arbejdspladsen, og en mindre del gennem andre kilder som venner, fagforening eller undervisningsinstitutioner.

Undersøgelsen viste, at langt hovedparten af deltagerne oplevede kurserne som nyttige. Over halvdelen angav, at de havde haft stor nytte af kurserne. Udbyttet bestod især af, at deltagerne oplevede at have opnået konkrete forbedringer af deres færdigheder, mere viden om deres egne vanskeligheder og større selvtillid angående læsning og skrivning. Nærmere analyser af resultaterne viste, at den oplevede effekt øgedes med antallet af læse- og skrivekurser, som de voksne havde deltaget i.

I undersøgelsen indgik ikke mål for deltagernes læse- og skrivefærdigheder, og den viser derfor ikke noget om, hvorvidt deltagerne objektivt målt faktisk forbedrede deres færdigheder.

Forfatterne til rapporten om undersøgelsen vurderer, at det metodiske og pædagogiske oplæg var temmelig ad hoc-præget, varierede meget mellem forskellige kursussteder og var afhængigt af de enkelte undervisere. Forfatterne konkluderer, at selv om deltagerne oplevede kurset som nyttigt og værdifuldt, havde det et betydeligt forbedringspotentiale, hvad

\footnotetext{
${ }^{118}$ Solheim, I. \& Ytrehus, S. (2005). Lese- og skriveopplæring som nytter. Etterundersøkelse av deltakere på AOFs lese- og skrivekurs (p. 35). Oslo: Forskningsstiftelsen Fafo.

${ }^{119}$ Solheim, I. \& Ytrehus, S. (2005). Lese- og skriveopplæring som nytter. Etterundersøkelse av deltakere på AOFs lese- og skrivekurs. Oslo: Forskningsstiftelsen Fafo.
} 
angik metodik og pædagogik (jf. Solheim \& Ytrehus, 2005; Solheim, $2006^{120}$ ).

4.3.2.3 Støtteordning til igangsættelse af kurser på virksomheder: Program for basiskompetanse i arbeidslivet (BKA)

Den norske regering har fra 2006 igangsat „Program for basiskompetanse i arbeidslivet“ (BKA). Gennem programmet kan virksomheder søge midler til undervisning for egne ansatte i grundlæggende færdigheder i læsning, skrivning, regning og brug af IT-redskaber. Der kan også søges om tilskud til afdækning af arbejdstageres og arbejdssøgeres basisfærdigheder og til motivationsarbejde. Læringscentret Vox har det faglige ansvar for programmet. ${ }^{121}$

\subsubsection{Eksempler på tidligere erfaringer med læse- og skrivekurser på} virksomheder

Der er i Norge blevet gennemført læse- og skrivekurser på forskellige virksomheder, blandt andet på Jotun-fabrikkerne i Sandefjord og Linjegods i Oslo. Underviseres og virksomheders erfaringer fra disse og tilsvarende tiltag har været præsenteret på forskellige konferencer. ${ }^{122}$

Solheim (2006) har endvidere gennemført en evaluering af et samarbejdsprojekt rettet mod læsning og skrivning i arbejdslivet. ${ }^{123}$ Projektet havde blandt andet til formål at afprøve metodikker for strategilæring inden for forskellige områder, blandt andet på virksomheder. Solheim konkluderer imidlertid, at projektet har været forbundet med alvorlige metodiske svagheder, og at afprøvningen af metoder ikke er blevet evalueret og testet på en systematisk måde.

Der synes ikke at være gennemført større, systematiske undersøgelser af effekten af læse- og skriveundervisning på virksomheder i Norge.

Læringscentret Vox har publiceret en vejledning om, hvordan man kan tilrettelægge læse- og skriveundervisning i en virksomhed og motivere medarbejderne til at deltage. Vejledningen er baseret på erfaringer fra tidligere gennemførte projekter. ${ }^{124}$

\footnotetext{
${ }^{120}$ Solheim, I. (2006). Strategi- og samarbeidslæring: utprøvning og spredning. Evaluering av samarbeidsprosjekt rettet mot læringsstrategier og leseforståelse i tilknytning til arbeidslivet. Oslo: Norsk Regnesentral.

${ }^{121}$ Jf. Beskrivelse af „Program for basiskompetanse“ på Vox’ website. (http://www.vox.no/templates/CommonPage.aspx?id=1674)

${ }^{122}$ Jf. fx præsentationer afholdt på Vox’ konferencer „Voksnes lese- og mestringskompetanse“ og „Startkonferansen for prosjekter i Program for basiskompetanse i arbeidslivet“. Præsentationerne kan downloades fra Vox website. (http://www.vox.no/templates/CommonPage.aspx?id=2184)

${ }^{123}$ Solheim, I. (2006). Strategi- og samarbeidslæring: utprøvning og spredning. Evaluering av samarbeidsprosjekt rettet mot læringsstrategier og leseforståelse i tilknytning til arbeidslivet. Oslo: Norsk Regnesentral.

${ }^{124}$ Letrud, K.H. (2004). Fra sjenanse til verdighet. A legge til rette for lese- og skriveutvikling i egen bedrift. Oslo: Vox. (http://www.vox.no/upload/Nedlastingssenter/sjenanseogverdighet.pdf )
} 
4.3.2.5 Særlige hjælpemidler for læsehandicappede på arbejdsmarkedet Der findes forskellige teknologiske hjælpemidler, som kan støtte læsehandicappede voksne i arbejdssammenhæng. Fx er der udviklet og afprøvet et særligt IT-baseret staveprogram, „LingDys“, som blandt andet er blevet afprøvet på voksne, der havde eller søgte arbejde. ${ }^{125}$ For en nærmere beskrivelse af mulighederne for at få teknologisk læse- og skrivestøtte i arbejdslivet i Norge henvises der til en nyligt udgivet nordisk DVD med tilhørende informationsmateriale. ${ }^{126}$ (Materialet beskrives nærmere i afsnit 4.7 om fælles-nordiske tiltag).

\subsubsection{Støtteforanstaltninger i uddannelsessammenhcenge}

4.3.3.1 Beskrivelse af rammer for støtteforanstaltninger for voksne med læsevanskeligheder inden for „videregående opplæring“

I Norge har voksne født før 1 . januar 1978 ret til „videregående opplæring“, hvis de har fuldført grundskolen, men ikke fuldført „videregående opplæring“. Undervisningen skal tilpasses i forhold til den enkeltes behov. ${ }^{127}$ Amtskommunerne (norsk: „fylkeskommunerne“) har ansvaret for den ,videregående opplæring“ af både almen og erhvervsfaglig karakter. Elever, som ikke har eller ikke kan få udbytte af det ordinære undervisningstilbud, har ret til specialundervisning, hvis der foreligger en sagkyndig vurdering, der dokumenterer elevens særlige behov. ${ }^{128}$

\subsubsection{Beskrivelse af praksis inden for „videregående opplæring“}

Læringscentret Vox har foretaget en spørgeskemaundersøgelse blandt 725 repræsentativt udvalgte voksne, som i foråret 2003 var meldt til eksamen i ,videregående opplæring“. ${ }^{129}$ Undersøgelsen viste blandt andet, at $19 \%$ af deltagerne oplyste, at de havde læse- og skrivevanskeligheder. Af dem, som angav at have læse- og skrivevanskeligheder, var $41 \%$ blevet testet for disse vanskeligheder, $16 \%$ havde fået undervisning, der var tilpasset i forhold til deres læse- og skrivevanskeligheder, og $27 \%$ havde fået særlige vilkår til eksamen på grund af læse- og skrivevanskelighederne.

På basis af interviews med amtskommunernes skoleadministration i 2003 foretog Vox en undersøgelse af, hvordan amtskommunerne håndte-

\footnotetext{
${ }^{125}$ Rikstrygdeverket, Senter for IKT-hjelpemidler \& Nonite (2005). Arbeidstakere og arbeidssøkere med lese-/skrivevansker - 2002-2004. Projektrapport. (Dokumentet findes som en del af det norske informationsmateriale på følgende DVD: NAV NONITE - Nordnorsk IKT-senter (2006). Nordisk informations DVD om teknologisk læese- og skrivestøtte i arbejdslivet. Bodø: NAV NONITE - Nordnorsk IKT-senter.)

${ }^{126}$ NAV NONITE - Nordnorsk IKT-senter (2006). Nordisk informations DVD om teknologisk lese- og skrivestøtte i arbejdslivet. Bodø: NAV NONITE - Nordnorsk IKT-senter.

127 § 4A-3 i „Lov om grunnskolen og den videregående opplæring (opplæringsloven)“. (http://www.lovdata.no/all/nl-19980717-061.html)

${ }^{128}$ § 5-1 „Lov om grunnskolen og den videregående opplæring (opplæringsloven)“

${ }^{129}$ Engesbak, H. \& Stubbe, T.A. (2005). I videregående som voksen. Voksnes rett til grunnskole og videregående opplæring (pp. 38-40). Oslo: Vox.
} 
rede ansvaret for at give voksne realkompetencevurdering og et tilbud inden for „videregående opplæring“, som er tilpasset den enkeltes behov. ${ }^{130}$ Ifølge Haugerud, Røstad \& Stubbe (2005) viste undersøgelsen blandt andet, at flere af amtskommunerne oplyste, at de var opmærksomme på voksne, som havde læse- og skriveproblemer, men at indsatsen over for denne gruppe varierede meget i de forskellige amtskommuner. En enkelt amtskommune tilbød alle voksne, som begyndte på ,videregående opplæring“ en test for at afdække eventuelle læse- og skrivevanskeligheder, og de voksne, som vurderedes at have behov for det, fik tilbudt gratis brug af lydbøger og et ekstra kursus i brug af forskellige hjælpemidler såsom PC. Nogle af de øvrige amtskommuner havde ifølge undersøgelsen også etableret rutiner med henblik på at afdække læse- og skrivevanskeligheder. I et enkelt amt blev alle unge og voksne inden for den „videregående opplæring“ således screenet, hvorefter der blev foretaget en grundigere testning af de elever, som skønnedes at have behov for det. Dette var imidlertid langt fra gængs praksis i alle amtskommunerne. Haugerud, Røstad \& Stubbe (2005) vurderer på basis af interviewundersøgelsen med amtskommunernes skoleadministration og den ovenfor omtalte spørgeskemaundersøgelse med voksne i „videregående opplæring“, at indsatsen over for voksne deltagere med læse- og skrivevanskeligheder i praksis er relativt tilfældig, og at der fortsat er lang vej tilbage, førend voksnes læse- og skrivevanskeligheder er en selvfølgelig og integreret del af det undervisningstilbud, de får.

4.3.3.3 Eksempel på særligt indskolingsprojekt for voksne med læse- og skrivevanskeligheder ved Sandefjord videregående skole

Ved Sandefjord videregående skole blev Projekt „Strategilaring“ igangsat i 2001 med økonomisk støtte fra læringscentret Vox. ${ }^{131}$ Som led i projektet udvikledes særligt tilrettelagte indskolingskurser for voksne med læse- og skrivevanskeligheder. Kurserne indeholdt blandt andet eksamenstræning og vejledning i opbygning af projektopgaver. I alt deltog 120 voksne, som var i færd med at tage „fagbrev“ ved Sandefjord videregående skole. Af de 120 deltagere var der kun én, der dumpede og ikke fik „fagbrev“. Til sammenligning har man på Sandefjord videregående skole ifølge projektlederen tidligere oplevet, at omkring $30 \%$ af de voksne deltagere dumpede.

\subsubsection{Igangværende udviklingsarbejde vedr. læsestrategier i} „videregående opplæring“

I Norge har Utdanningsdirektoratet i samarbejde med aktører og repræsentanter fra forskellige fagmiljøer udviklet en strategiplan for stimulering af læselyst og læsefærdighed under overskriften „Gi rom for le-

\footnotetext{
${ }^{130}$ Haugerud, V., Røstad, S. \& Stubbe, T.A. (2005). Intensjoner og realiteter. Fylkeskommunenes håndtering av voksnes rett til videregående opplæring (pp. 54-55). Oslo: Vox.

${ }^{131}$ Hansen, G. (2003). Vellykket Voksenopplæring i Vestfold. Bris 2, 54-57.
} 
sing! “. Målet er, at en særlig indsats på dette område i løbet af fem år skal føre til en målbar forbedring i læsefærdighederne hos norske børn og unge. Der er bevilliget midler til en række forskellige projekter, herunder et udviklingsarbejde vedr. læsestrategier i „,videregående opplæring“, som varetages af Lesesenteret i Stavanger. ${ }^{132}$ Projektet strækker sig over perioden 2005-2007 og består i at udvikle og producere materiale til både studieforberedende og erhvervsfaglige studieretninger. Materialet skal være et hjælpemiddel for lærere til at videreudvikle læsestrategierne blandt elever inden for den „videregående opplæring“. Materialet, som udarbejdes, skal følges op med kurser og andre efteruddannelsestilbud til lærerne.

\subsubsection{Scerlige undervisningstilbud for indvandrere}

\subsubsection{Beskrivelse af tilbud}

Ifølge „Introduksjonsloven“ fra 2005 har indvandrere, som får ophold i Norge med mulighed for permanent opholdstilladelse, som hovedregel både ret og pligt til at deltage i 300 timers gratis undervisning i norsk. Ved behov kan retten udvides med op til yderligere 2700 timers undervisning. ${ }^{133}$

I 2005 er der udviklet en ny læreplan i norsk og samfundskundskab for voksne indvandrere. ${ }^{134}$ I denne læreplan tages der udgangspunkt i det europæiske sprogbeskrivelsessystem Common European Framework of Reference for Languages (CEFR). Indvandrerne fordeles på tre spor, hvor tempoet og progressionen i undervisningen er forskellig. Placeringen foretages ud fra indvandrernes skole- og uddannelsesbaggrund samt deres modersmål. Eksempelvis antages indvandrere med kort skolebaggrund og et modersmål, som ligger fjernt fra norsk, at have en større læringsopgave end andre, og dette får betydning for indplaceringen. For hvert af de tre spor er der beskrevet mål for det niveau af mundtlige og skriftlige færdigheder, som indvandrerne forventes at opnå på de pågældende spor. Der er udviklet prøver til dokumentation af norskfærdigheder på de forskellige niveauer. ${ }^{135}$

\subsubsection{Undersøgelse af praksis}

Haugerud (2006) påpeger i en evalueringsrapport fra læringscentret Vox, at ordningen med ret og pligt til norskundervisning ikke omfatter alle

\footnotetext{
${ }^{132}$ Utdannings- og Forskningsdepartementet (2005). Strategiplan. Gi rom for lesing. Strategi for stimulering af leselyst og leseferdighet. (http://www.utdanningsdirektoratet.no/upload/ Satsningsomraader/Gi_rom_for_lesing_strategiplan2003-07.pdf)

${ }^{133}$ Lov om introduksjonsordning og norskopplæring for nyankomne innvandrere. H 20/05

${ }^{134}$ Utdannings- og forskningsdepartementet (2005). Læreplan i norsk og sammfunnskunnskap for voksne innvandrere. (http://www.utdanningsdirektoratet.no/upload/larerplaner/ lareplan\%20i\%20norsk\%20og\%20samfunnskunnskap\%20for\%20voksne\%20innvandrere.pdf)

${ }^{135}$ Vox (2005). Sentrale begreber i norskplanen. I: Metodisk Vejledning. Læreplan i norsk og sammfunnskunnskap for voksne innvandrere. Oslo: Vox. (pp. 26-31).
} 
indvandrere, og at der derfor er fare for, at mange indvandrere melder sig til tilbud inden for grundskolen, selv om grundskoletilbuddet ikke dækker deres behov for målrettet norskundervisning. Vox har fået meldinger fra kommuner og voksenundervisningscentre om et øget pres fra indvandrere på grundskoletilbuddet. ${ }^{136}$

Et andet problem er ifølge Haugerud, at der tilsyneladende ikke hersker enighed om, hvilket niveau af norsk indvandrere skal have for at kunne klare sig i arbejds- og uddannelsessammenhæng, når de har afsluttet norskundervisningen. Således har både arbejdsgivere, arbejdsmarkedsmyndigheder og optagelsesmyndigheder ved „videregående skoler“ hævdet, at niveauet i norsk er for lavt hos mange indvandrere, som har gået til sprogundervisning og aflagt de norskprøver, der formelt kræves for at gå videre i systemet. Arbejdsformidlingerne har i lighed med mange amter indført egne test før optagelse af indvandrere i kursus- og uddannelsessammenhæng $i$ et forsøg på at sikre, at indvandrernes sproglige niveau er tilstrækkeligt højt til, at de kan få fuldt udbytte af undervisningen.

4.3.4.3 Eksempel på afsluttet udviklingsarbejde vedrørende IKT i norskundervisningen for voksne indvandrere (INOVI)

Projektet „IKT i norskopplceringen for voksne innvandrere“ (forkortet til INOVI) blev gennemført som et udviklingsarbejde i perioden 2003-2005 i 15 forskellige norske kommuner. ${ }^{137} 858$ voksne indvandrere på forskellige sproglige niveauer og med forskellig skolebaggrund deltog i projektet, hvor der blev afprøvet forskellige måder at bruge IKT på i norskundervisningen. Undervisningen omfattede brug af tekstbehandling, e-mail og netbaserede undervisningsprogrammer. Undervisningen var organiseret på flere forskellige måder. Nogle af indvandrerne deltog således i IKT-undervisning som en integreret del af norskundervisningen, mens andre fik IKT-undervisning som et ekstra tilbud ved siden af den ordinære norskundervisning. På en enkelt skole blev IKT-undervisningen udbudt som fjernundervisning via internettet for deltagere med god skolebaggrund og godt kendskab til norske forhold. Der indgik ikke direkte mål for deltagernes udbytte af undervisningen, men i en afsluttende rapport fra læringscentret Vox opsummeres de deltagende kommuners tilbagemeldinger vedrørende projektet. De deltagende kommuner har samstemmende meldt tilbage, at brugen af internetbaserede undervisningsprogrammer gør det nemmere at give indvandrere en mere fleksibel og individuelt tilrettelagt undervisning. Det vurderes, at deltagerne lettere kan arbejde i deres eget tempo, og at læreren får frigjort tid, som kan bruges til vejledning og opfølgning. Ifølge rapporten er det vanskeligt at vurdere, om brugen af IKT har givet et større læringsudbytte, men flere forhold

\footnotetext{
${ }^{136}$ Haugerud, V. (2006). BASIS! Voksnes læring 2006 - tilstand, utfordringer og anbefalinger. Oslo: Vox. (pp. 52-61)

${ }^{137}$ Vox (2005). INOVI. Ikt i norskopplæringen for voksne innvandrere. Oslo: Vox.
} 
tyder på, at især indvandrere med god skolebaggrund kan udnytte de muligheder, som IKT giver, og opnå en hurtigere progression. Samtidig har mange af undervisningsstederne meldt tilbage, at en undervisningsform med brug af netbaserede programmer kræver mere af lærerne end traditionel undervisning, og mange lærere har ytret ønske om få mere undervisning i, hvordan IKT kan integreres i norskundervisningen.

\subsubsection{Afsluttet undersøgelse af norskundervisning for voksne analfabeter}

Hvenekilde et al. (1996) observerede indvandrerundervisning i norsk for voksne analfabeter og deltagere uden funktionelle læse- og skrivefærdigheder. ${ }^{138}$ Interviews viste, at mange af deltagerne i undervisningen hellere ville bruge tid og kræfter på at blive bedre til at tale og forstå norsk frem for træning af læse- og skrivefærdigheder. Imidlertid fyldte alfabetiseringen meget i undervisningstilbuddet, og undersøgelsen tydede på, at mange af de analfabeter, som fulgte kurser på 750 timer, faktisk også lærte at afkode på norsk - det vil sige, at de „knækkede koden“ og erhvervede sig teknisk læsefærdighed. Imidlertid tog de kun sjældent læsefærdighederne i brug uden for skolen. Kun ganske få af dem ændrede således adfærd i dagligdagen i forhold til før deres deltagelse i undervisningen.

\subsection{Island}

\subsubsection{Sammenfatning vedrørende islandske tilbud og tiltag}

I Island er ordblindhed ikke defineret som et handicap. Der findes ikke nogen paragraffer i love eller regelmenter, som garanterer rettigheder eller tiltag for personer med læsevanskeligheder, fx diagnosticering, læsekurser eller hjælpemidler. Hvis voksne i uddannelses- eller arbejdssammenhæng har brug for individuel diagnostisering, må de som hovedregel kontakte privat praktiserende specialister og betale selv.

Imidlertid gives der af og til offentlig støtte til tiltag for voksne med læse- og skrivevanskeligheder. Der findes således et kursustilbud for ordblinde voksne med overskriften „Tilbage til uddannelse“, som delvist er betalt af staten (jf. beskrivelse af tilbuddet i afsnit 4.4.2.1). En væsentlig del af indholdet af dette kursustilbud består af elementer fra et amerikansk undervisningsprogram, hvor deltagerne især arbejder med at forme bogstaver og ord i ler. Endvidere tilbydes der i Reykjavik kommune specialundervisning, som deltagerne selv betaler en del af (jf. 4.4.2.2). Desuden tilbyder flere private firmaer kurser i læsning (jf. 4.4.2.3). Der har tidligere med støtte fra en fond under Undervisningsministeriet været

\footnotetext{
${ }^{138}$ Hvenekilde, A., Alver, V., Bergander, E., Lahaug, V. \& Midttun, K. (1996). Alfa og Omega. Om alfabetiseringsundervisning for voksne fra språklige minoriteter. Oslo: Novus Forlag.
} 
igangsat et særligt tilrettelagt forløb for en gruppe kortuddannede ordblinde (jf. 4.4.2.4).

Inden for den „videregående skole“ (islandsk: framhaldsskóli) findes der forskellige offentlige tilbud om støtteforanstaltninger for personer, der er diagnosticeret ordblinde, herunder dispensationsmuligheder i forbindelse med eksamen og tilbud om specialundervisning (jf. 4.3.3.2).

\subsubsection{Tilbud og tiltag i arbejds- og fritidssammenhæenge}

I Island er læsevanskeligheder eller ordblindhed ikke defineret som et handicap. Der findes ikke nogen paragraffer i love eller regelmenter, som garanterer rettigheder eller tiltag for personer med læsevanskeligheder, f.eks. diagnosticering, læsekurser eller hjælpemidler. ${ }^{139}$ Imidlertid gives der af og til offentlig støtte til tiltag for voksne med læse- og skrivevanskeligheder. Sådanne tiltag beskrives i det følgende.

4.4.2.1 Kursustilbud for ordblinde: „Tilbage til uddannelse“

(„Aftur í nám“)

"Arbejdslivets undervisningscenter" (islandsk: Fræðslumiðstöð atvinnulífsins) er et resultat af et samarbejde mellem fagforbundet Alpýðusamband Íslands og arbejdsgiverforeningen Starfsafls omkring voksenundervisning inden for det islandske arbejdsmarked. ${ }^{140}$ Den islandske stat yder over en treårig periode (2006-2008) tilskud til undervisningscentret til varetagelse af forskellige opgaver, herunder udvikling af undervisningsmaterialer for indvandrere og kursustilbud for kortuddannede voksne. Blandt disse kurser findes et for ordblinde/dyslektikere med titlen „Tilbage til uddannelse“("Aftur í nám").

„Arbejdslivets undervisningscenter“ (Fræðslumiðstöð atvinnulífsins) samarbejder med de såkaldte centre for livslang læring, som er oprettet i samarbejde mellem kommuner, fagforeninger og arbejdsgivere. Der er ti sådanne centre i Island, hvoraf ét ligger i Reykjavík (Mímir-símenntun). Disse centre kan få del i statens tilskud til „Arbejdslivets undervisningscenter“, hvis de udbyder kurser, som er anerkendt af „Arbejdslivets undervisningscenter“" og vurderes positivt af en evalueringsgruppe bestående af repræsentanter fra Undervisningsministeriet, de „videregående skoler“ (islandsk: Framhaldsskóli) og „Arbejdslivets undervisningscenter“.

Mímir, centret for livslang læring i Reykjavik, udbyder det ovenfor nævnte kursus for ordblinde, „Tilbage til uddannelse“(„Aftur í nám“), som Rannveig Lund i forbindelse med det nordiske forprojekt har studeret og aflagt rapport om. ${ }^{141}$ På hvert kursus deltager $11-16$ elever. Der

\footnotetext{
${ }^{139}$ Lund, R. (2006). Rapport. Innsamling av nasjonelle opplysninger i Island i forbindelse med nordisk førprojekt om kortutdannede voksnes lesning. Reykjavik: Lestrarsetur Rannveigar Lund.

140 http://www.fraedslumidstod.is/default.asp?webid=5

${ }^{141}$ Lund, R. (2006). Rapport. Innsamling av nasjonelle opplysninger i Island i forbindelse med nordisk førprojekt om kortutdannede voksnes lesning. Reykjavik: Lestrarsetur Rannveigar Lund.
} 
har været afholdt syv kurser, og for tiden er der lang venteliste. Kurset varer i alt 95 timer og består af fire adskilte elementer:

- Styrkelse af selvværd (16 timer)

- Undervisning i islandsk (20 timer)

- Computerundervisning (16 timer)

- Træning baseret på amerikaneren Ron Davis’ undervisningssystem „Rettelse af dysleksi“ (40 individuelle timer).

Desuden indgår der som en del af kurset en individuel time med en konsulent samt to timer til evaluering af kurset. ${ }^{142}$ Kurset kan meritoverføres og er af Undervisningsministeriet vurderet til at give 7 point inden for den „videregående skole“ (Framhaldsskóli). Indvandrere har ikke adgang til kurset. Eleverne betaler selv kursusafgiften i første omgang, men de fleste får refunderet op til $75 \%$ af beløbet fra deres fagforening.

I forbindelse med det nordiske forprojekt har Rannveig Lund observeret en undervisningslektion, hvori træning baseret på det amerikanske Ron Davis-program fandt sted. På basis af observationen og et efterfølgende interview med underviseren/vejlederen gives der følgende beskrivelse af denne del af kurset:

\section{Beskrivelse af Ron Davis-undervisningsprogram („Rettelse af dysleksi“)}

Kurset indledes med et elevinterview. Der anvendes ingen prøver til at vurdere elevens standpunkt i læsning. En del af kursustiden bruges til opmærksomhedstræning.

„Rettelse af dysleksi“ foregår på den måde, at eleven former bogstaver (store/små) i ler, efterhånden som de nævnes. Der lægges vægt på bogstavrækkefølgen i alfabetet - frem og tilbage. Vejlederen fortæller, at nogle elever bliver ved med at stoppe op ved enkelte bogstaver og har vanskeligheder med at huske disse. Dette forklares med, at individet har ubehagelige minder fra sin skolegang angående bogstaver og læseindlæring. Ord (fx småord som og, at, til, med, igen osv.) samt tegn som fx punktum, komma osv., formes også i ler. I den undervisningslektion, som blev observeret, arbejdede eleven med at forme ordet „igen“ (med betydningen: om igen). Eleven (en kvinde) formede to kvindefigurer af leret og så for sig i tankerne, at hun vaskede det samme gulv om og om igen. $70-80 \%$ af undervisningstiden går med at forme i ler. Læsning begynder, når denne træning af bogstaver og tegn er gennemført, og når eleven kan se de såkaldt „billedløse ord“ ${ }^{143}$ i sit indre. Eleven vælger selv bøger at læse, og ofte sker det, at han vælger de bøger, han tidligere har ønsket at kunne læse.

En målsætning med kurset er at forbedre læseforståelsen. Det foregår ved, at eleven læser en sætning, stopper op og genfortæller sætningens indhold ud fra det billede, han ser for sig. Der arbejdes med retskrivning på den måde, at regler fra lærebøger formes i ler.

\footnotetext{
${ }^{142}$ Fræðslumiðstöð atvinnulífsins [Arbejdslivets undervisningscenter] (2004). Aftur í nám námskrá. [Tilbage til uddannelse - studieplan]. Sími: Fræðslumiðstöð atvinnulífsins.

143 „Billedløse ord“ betegnes normalt som funktionsord.
} 
Elevens fremskridt vurderes ud fra hans oplevelse af kurset og hans følelser omkring hele processen. Efter vejlederens udsagn sker der store fremskridt hos de fleste elever. Opfølgning er en vigtig del af „rettelsen af dysleksien“. Vejlederen møder eleven efter kursets afslutning, i nogle tilfælde op til fire gange, men i mellemtiden bør eleven fortsætte med at forme „billedløse ord“.

Centrene for livslang læring i landområderne kan også få del i statens tilskud til „Arbejdslivets undervisningscenter“, hvis de udbyder kurser i læsning, som er godkendt af det islandske undervisningsministerium. På tidspunktet for indsamlingen af de islandske data til forprojektet, gjaldt dette kun kurser af den type, som er beskrevet ovenfor. ${ }^{144}$

\subsubsection{Tilbud om specialundervisning for voksne med læse- og} stavevanskeligheder

I Reykjavik kommune tilbydes der specialpædagogisk undervisning i læsning for voksne med læse- og skriveproblemer. ${ }^{145}$ Der er ansat en speciallærer, som især giver individuel undervisning. Eleven betaler selv en lille del af udgiften til undervisningen (12-15.000 islandske kr.). Socialrådgivere, som arbejder i helse- og socialcentre, henviser til dette tilbud, og det annonceres også i aviser. Undervisningen tilrettelægges ud fra den enkeltes behov. Diagnosen stilles af speciallæreren, som anvender samme læsetekst for alle elever samt nogle uformelle prøver. Nogle af de elever, der har modtaget dette tilbud, har været personer, som har haft en hjerneblødning og som følge heraf har fået læsevanskeligheder. Også indvandrere har modtaget undervisning på individuel basis.

\subsubsection{Eksisterende tilbud om læseundervisning i privat regi}

Flere private firmaer tilbyder kurser i læsning. Fx tilbyder firmaerne Hraðlestrarskólinn ${ }^{146}$ og Photoreading ${ }^{147}$ kurser med henblik på forøgelse af læsehastighed. Målgrupperne for kurserne er både ordblinde og personer uden læsevanskeligheder.

Gennem Nemendapjónustan ${ }^{148}$ kan alle mod betaling få støtte i forskellige fag, herunder hjælp med læsning.

Derudover findes der flere firmaer, som tilbyder undervisning af ordblinde efter den amerikanske Ron Davis-metode (jf. beskrivelse af eksempel på en sådan undervisning i afsnit 4.4.2.1). ${ }^{149}$

\footnotetext{
${ }^{144}$ Lund, R. (2006). Rapport. Innsamling av nasjonelle opplysninger i Island i forbindelse med nordisk førprojekt om kortutdannede voksnes lesning. Reykjavik: Lestrarsetur Rannveigar Lund.

${ }^{145}$ Lund, R. (2006). Rapport. Innsamling av nasjonelle opplysninger i Island i forbindelse med nordisk førprojekt om kortutdannede voksnes lesning. Reykjavik: Lestrarsetur Rannveigar Lund.

${ }^{146}$ Jf. virksomhedens website: http://www.hradlestrarskolinn.is/

${ }^{147} \mathrm{Jf}$. virksomhedens website: http://www.photoreading.is/

${ }^{148}$ Jf. virksomhedens website: http://www.namsadstod.is/

${ }^{149} \mathrm{Jf}$. liste over links til disse firmaer på website: http://www.dyslexia.com/cb/wlinks. pl?cgifunction=Search\&Language=Icelandic
} 
4.4.2.4 Afsluttet særligt tilrettelagt undervisningsforløb for ordblinde voksne („Skridt til selvhjælp i læsning, retskrivning og IT“)

I 2004-2005 blev der afholdt et særligt kursus på 60 timer for otte voksne ordblinde $\mathrm{i}$ et center for livslang læring $50 \mathrm{~km}$ uden for Reykjavik. ${ }^{150}$ Kurset blev støttet af en fond under Undervisningsministeriet. Ingen af de otte deltagere havde en uddannelse ud over grundskolen, og halvdelen af dem var arbejdsløse. I undervisningsforløbet indgik blandt andet træning af læseforståelse, afkodningsfærdigheder, sproglig opmærksomhed, skriftlig fremstilling og retskrivning. Der blev arbejdet med IT, herunder brug af stavekontrol i forbindelse med e-mail.

Ved begyndelsen og afslutningen af kurset blev der gennemført test af deltagernes færdigheder i blandt andet afkodning og opmærksomhed på lydene i sproget (fonologisk opmærksomhed). Testresultaterne viste, at omkring halvdelen af deltagerne efter kurset læste ord hurtigere/og eller mere præcist end før kurset, og at hovedparten af deltagerne gik frem på en test af fonologisk opmærksomhed i løbet af kurset.

\subsubsection{Støtteforanstaltninger i uddannelsessammenhæenge}

4.3.3.1 Beskrivelse af rammer for støtteforanstaltninger for voksne med læsevanskeligheder inden for den „videregående skole“ (framhaldsskóli) Den „videregående skole“ (islandsk: framhaldsskóli) indeholder en boglig linje, en erhvervsfaglig linje og desuden en almen linje for personer, der ikke opfylder betingelserne for optagelse på en af de øvrige linjer. Inden for denne skoleform findes daghold for unge i alderen 16-20 år samt særlige aftenhold for voksne (islandsk: öldungadeildir).

I loven for den videregående skole nr. 80/1996 findes der ingen bestemmelser angående elever med ordblindhed (dysleksi). Derimod findes en sådan bestemmelse i studieplanen for den videregående skole (1999; 2004), hvori loven iværksættes. ${ }^{151}$ Det fremgår heraf, at ordblinde elever kan søge om dispensation i enkelte fag, men på betingelse af, at der foreligger en bekræftelse fra en specialist ${ }^{152}$ på, at den pågældende elev ikke er i stand til at gennemføre uddannelsen på grund af dysleksi eller andre sansedefekter. Det fremgår også, at institutionerne bør tage hensyn til dyslektikere, fx med tildeling af forlænget eksamenstid, særlig udformning af eksamensopgaver og brug af hjælpemidler samt om nødvendigt mundtlig eksamen i stedet for skriftlig eksamen. I enkelte tilfælde kan der

\footnotetext{
${ }^{150}$ Beskrivelse af projektet findes i bilag 2 i: Lund, R. (2006). Rapport. Innsamling av nasjonelle opplysninger i Island i forbindelse med nordisk førprojekt om kortutdannede voksnes lesning. Reykjavik: Lestrarsetur Rannveigar Lund.

${ }^{151}$ Lund, R. (2006). Rapport. Innsamling av nasjonelle opplysninger i Island i forbindelse med nordisk førprojekt om kortutdannede voksnes lesning. Reykjavik: Lestrarsetur Rannveigar Lund. http://brunnur.stjr.is/mrn/logogregl.nsf/FF6C260B2319251D002567BA004D88CB/5BF79E6E5 FA409ED00256E4300431F93?OpenDocument

${ }^{152}$ Af et svar fra Undervisningsdepartementet den 23.12.03 på en forespørgsel fra Rannveig Lund angående krav til specialister fremgår det, at det er de enkelte rektorer på skolerne, der afgør, hvem der anses for kvalificeret til at stille dysleksi-diagnoser.
} 
være behov for at tage utraditionelle vurderingsmåder i brug (Aðalnámskrá framhaldsskóla, almennur hluti, kafli 8.1.3, bls. 34). ${ }^{153}$

Elever som ikke har islandsk som modersmål har ret til undervisning $\mathrm{i}$ islandsk i overensstemmelse med en særlig studieplan. ${ }^{154}$

4.3.3.2 Eksempler på støtteforanstaltninger for elever med læsevanskeligheder inden for den „videregående skole“ (framhaldsskóli)

Det er en forudsætning for, at en elev kan tildeles særlige vilkår ved eksamen, at der foreligger dokumentation for, at eleven er ordblind (dyslektiker). I forbindelse med den islandske del af det nordiske forprojekt blev en række af de videregående skoler spurgt om, hvordan eksamen blev tilrettelagt for ordblinde elever. ${ }^{155}$ Nedenfor følger et eksempel på de særlige vilkår, som en elev kan opnå:

- forlænget eksamenstid

- ændret opsætning af opgaver, som ofte trykkes på farvet papir

- opgaver læst ind på CD eller iPod

- mundtlig eksamen i stedet for skriftlig eksamen

- personlig assistanse med læsning i forbindelse med eksamen

- eksamensopgaver oplæses og besvares ved hjælp af computer i stedet for på papir på grund af læse- og skrivevanskeligheder

- opgaver besvares på computer i stedet for på papir på grund af skrivevanskeligheder.

Forespørgslen viste endvidere, at der i 9 af 14 af de videregående skoler med forskellige linjer findes tilbud om læsekurser, hvor eleverne opnår point for at deltage.

Fjölbrautarskólinn við Ármúla (FÁ), som er en videregående dagskole, har i løbet af de sidste syv år udviklet et særligt kursus for elever med ordblindhed (dysleksi). Skolen er førende, hvad angår støtte til elever med dysleksi, og flere af de andre videregående skoler bruger nu også denne skoles model (den såkaldte FÁ-model), mens andre skoler planlægger at indføre den. Nedenfor følger en beskrivelse af FÁ- modellen:

\section{Beskrivelse af FÁ-modellen}

Kurset løber hen over 14 uger og består af fire timers undervisning pr. uge.

Halvdelen af tiden bliver anvendt på læsning, islandsk og IT-teknik. Deltagernes læsestrategier og læsehastighed trænes ud fra indholdet af teksten. Der indøves blandt andet ord fra lærebogstekster. Læreren vælger cirka 20 ord/begreber fra teksten og gennemgår disse. Derefter læser eleven ordene gang på gang, og læsetiden tjekkes og skrives ned hver gang. Læsestrategier trænes ud fra formålet med læsningen af tekster i forskellige lærebøger. Ved undervisning i retskrivning lægges der vægt på forståelsen af ordene. Eleven deler lange ord i betydningsbæ-

\footnotetext{
${ }^{153}$ http://bella.mrn.stjr.is/utgafuskra/rit.adp?id=34495 (PDF file).

${ }^{154}$ Aðalnámskrá framhaldsskóla, almennur hluti, kafli 9.1. bls. 37

${ }^{155}$ Lund, R. (2006). Rapport. Innsamling av nasjonelle opplysninger i Island i forbindelse med nordisk førprojekt om kortutdannede voksnes lesning. Reykjavik: Lestrarsetur Rannveigar Lund.
} 
rende enheder (morfemer). Han øver sig også i at se disse ord for sig som indre billeder. Hvis han har vanskeligheder med at skrive en bestemt del af ordet, prøver han at sætte en ramme omkring den del. Under overskriften „praktisering af skabende skrift“ (2-3 timer) får de ordblinde elever mulighed for at formulere sig skriftligt vedrørende sig selv og deres ordblindhed ved at sende læreren e-mail. Der bruges relativt meget tid på at vise eleven PC'ens muligheder, for eksempel syntetisk tale og forskellige IT-programmer. Desuden søger eleven på Internet for at finde emner og stof, som han kan bruge i forbindelse med uddannelsen.

Den anden halvdel af kurset bruges til træning af elevens selvtillid samt studieteknik.

Her gives der forklaring på, hvad dysleksi er og hvordan den kan ytre sig hos forskellige personer. Der lægges vægt på at styrke elevens selvsikkerhed, og der arbejdes sideløbende med emner som stress, kommunikation og eksamensangst. Eleven lærer om mnemoteknik og øver sig på at udarbejde tankekort (,mind mapping“).

Nogle af de videregående skoler anvender et læseprogram, som kaldes „Lestu betur“ (Læes bedre). ${ }^{156}$ Her lægges der vægt på at forbedre deltagernes læseforståelse gennem træning af læsehastighed. I en af de videregående skoler trænes ordblinde elever specielt i lyddiskriminering og lytteforståelse ved siden af træning af læsehastighed og brug af forskellige læsestrategier.

I skoler med erhvervsfaglige linjer er der ikke længere de samme krav til færdigheder i retskrivning som for ti år siden. Ringe stavefærdigheder er således ikke i sig selv en hindring for at tage en uddannelse. ${ }^{157}$

\subsubsection{Scerlige undervisningstilbud for indvandrere}

Der udbydes undervisning for indvandrere i mange forskellige regier, $\mathrm{fx}$ af de tidligere omtalte centre for livslang læring, kommunale undervisningscentre og private virksomheder. Der foreligger ikke oplysninger om tilbud, der specifikt retter sig mod at forbedre indvandreres læse-, skriveog IT-færdigheder og dermed kan have særlig interesse i forbindelse med det nordiske forprojekt. Det kan dog nævnes, at undervisnings- og rådgivningscentret The Intercultural Centre tilbyder arbejdspladser undervisning, der er særligt rettet mod at lære deltagerne det ordforråd, de har behov for i arbejdet. ${ }^{158}$

\footnotetext{
${ }^{156}$ Kolbeinsson, G. \& Ásbjörnsson F. (1994). Lestu betur [„Læs bedre“]. Reykjavík: IĐNÚ.

${ }^{157}$ Lund, R. (2006). Rapport. Innsamling av nasjonelle opplysninger i Island i forbindelse med nordisk førprojekt om kortutdannede voksnes lesning. Reykjavik: Lestrarsetur Rannveigar Lund.

${ }^{158}$ http://www.ahus.is/en/icelandic-language-courses.html
} 


\subsection{Finland}

\subsubsection{Sammenfatning vedrørende finske tilbud og tiltag}

Der foreligger ingen oplysninger om et specifikt undervisningstilbud inden for det finske offentlige system for voksne med læse- og stavevanskeligheder, hvis der ses bort fra foranstaltninger, som er knyttet til uddannelserne inden for „secondary school“ (finsk: toisen asteen koulu). De fleste aktiviteter inden for området igangsættes af interesseorganisationer for ordblinde. Sådanne organisationer har gennem de seneste år igangsat forskellige projekter $\mathrm{i}$ et forsøg på at skabe tilbud for voksne i arbejde. Flere af disse projekter er blevet finansieret af det finske spilleautomatforbund Raha-automaattiyhdistys (RAY). En af de største interesseorganisationer (HERO) har således med økonomisk støtte fra spilleautomatforbundet $\mathrm{fx}$ gennemført et bredspektret undervisningsforløb, som foruden læse- og skrivetræning blandt andet har involveret kinesiologiske kropsøvelser (jf. afsnit 4.5.2.5). Derudover har flere folkehøjskoler igangsat kurser og projekter, der retter sig mod personer med læse- og skrivevanskeligheder (jf. 4.5.2.2). Der er rapporteret erfaringer fra disse typer af projekter, men der foreligger ingen oplysninger om større, systematiske undersøgelser af, om en given undervisning har haft en målbar effekt på deltagernes faktiske færdigheder i læsning og skrivning eller relaterede færdigheder.

Der er med støtte fra staten etableret en række læeserådgivningscentre med det formål at informere om ordblindhed og tilbyde hjælp til ordblinde (jf. 4.5.2.7).

I uddannelsessammenhænge findes der forskellige offentlige tilbud om støtteforanstaltninger for personer med læse- og skrivevanskeligheder, herunder tilbud om specialundervisning (jf. 4.5.3.1). Inden for erhvervsuddannelserne er der i løbet af de seneste år udviklet nye test med henblik på at forbedre mulighederne for at identificere ordblinde deltagere (jf. 4.5.3.2). Der er desuden gennemført flere udviklingsprojekter med fokus på at øge underviseres viden om, hvordan de kan støtte deltagere med læse- og skrivevanskeligheder (jf. 4.5.3.5 og 4.5.3.6).

\subsubsection{Tilbud og tiltag i arbejds- og fritidssammenhcenge}

4.5.2.1 Rammer for tilbud og tiltag for voksne med læse- og skrivevanskeligheder

De fleste aktiviteter for voksne med læse- og skrivevanskeligheder igangsættes af non-profit-organisationer, som primært arbejder inden for de store byer. ${ }^{159}$ Det er op til de voksne selv at kontakte sådanne organisati-

\footnotetext{
${ }^{159}$ Ojanen, E. (2006). Finnish data for the Nordic pre-project. Jyväskylä: University of Jyväskylä, Niilo Mäki Institute. (Upubliceret rapport udarbejdet i forbindelse med nordisk forprojekt om voksne kortuddannedes læsning).
} 
oner. Endvidere er der på nogle folkehøjskoler taget initiativer, der sigter mod at støtte personer med læse- og skrivevanskeligheder. I det følgende gives der eksempler på projekter og initiativer, der er rettet mod voksne med læse- og skrivevanskeligheder.

4.5.2.2 Eksisterende tilbud om testning, information og undervisning på folkehøjskoler

På nogle folkehøjskoler (finsk: kansanopisto) udbydes der særlige kurser for personer med læse- og skrivevanskeligheder. Disse folkehøjskoler kan have en bestemt religiøs eller politisk baggrund. Som et eksempel kan nævnes folkehøjskolen Turun Kristillinen Opisto (Turku Christian Institute), som arbejder på evangelisk-luthersk grundlag. ${ }^{160}$ Denne højskole har organiseret kurser for ordblinde siden 1987 og oprettede i 1993 et center til støtte for ordblinde (Luki-tuki-keskus). Centret tilbyder screening for og diagnosticering af ordblindhed. Centret udvikler endvidere undervisnings- og informationsmaterialer og udbyder kurser, der informerer om og søger at afhjælpe læse- og stavevanskeligheder.

4.5.2.3 Projekt vedrørende udvikling og afprøvning af undervisningsmetoder til voksne med læse- og skrivevanskeligheder (projekt Lukki) I perioden 2002-2005 finansierede det finske spilleautomatforbund Rahaautomaattiyhdistys (RAY) Lukki-projektet. Dette projekt havde til formål at udvikle undervisningsmetoder og materialer, som kan bruges i forskellige læringsmiljøer som fx folkehøjskoler, fængsler og foreninger for arbejdsløse. De udviklede metoder og materialer er stadig i brug. Der blev i projektperioden organiseret undervisning for grupper på gennemsnitligt 10 personer. Disse grupper blev undervist af personer fra den i afsnit 4.5.2.2. nævnte folkehøjskole, Turun Kristillinen Opisto (Turku Christian Institute). Underviserne brugte et særligt materiale, som blandt andet indeholdt information om ordblindhed og de psykologiske konsekvenser heraf. I forløbene indgik foruden læse- og skriveundervisning blandt andet træning af psyko-sociale færdigheder samt kinesiologiske kropsøvelser med henblik på at aktivere forskellige områder af hjernen.161 Lukki-projektet er blevet evalueret af Haapasalo, Lund \& Halonen (2006).162 I forbindelse med evalueringen blev 227 deltagere fulgt. Omkring $30 \%$ af disse deltagere var i arbejde, mens resten var enten studerende, arbejdsløse, pensionerede eller i fængsel. Af rapporten fremgår det, at deltagerne udtrykte tilfredshed med gruppeøvelserne. Det anvendte materiale blev revideret på basis af kommentarer fra deltagerne og lærerne.

\footnotetext{
${ }^{160}$ Jf. skolens website: http://www.tk-opisto.fi/

${ }^{161}$ Lund, A. (2004). LUKKI-projekti. In: Hämäläinen Riitta, Riitta Salin ja Airi Valkama (eds.) Kromosomeista kaksoiskonsonantteihin, lukibussin matkakirja [„,From chromosomes to doubleconsonants: the journey story of Lukibussi“"]. Helsinki: Suomen kuntaliitto.

${ }^{162}$ Haapasalo, S., Lund \& Halonen (2006). Luki-lukkoja avaamassa 2002-2005. LUKKIhankkeen loppuraportti. [„Opening dyslexia-locks 2002-2005. The final report of LUKKI-project“]. Turku: Turun kristillisen opiston säätiö. (http://www.tk-opisto.fi/liitteet/tko-00010424-2.pdf)
} 
4.5.2.4 Igangværende udviklingsprojekt vedrørende internetservice for personer med læse- og skrivevanskeligheder (projekt Verkko-Lukki)

Projekt Verkko-Lukki begyndte i 2006 og fortsætter til udgangen af $2008 .{ }^{163}$ Projektet sigter mod at skabe en internet-service med træningsøvelser for personer med læse- og stavevanskeligheder. Der er opgaver på forskellige niveauer, fx øvelser i at kombinere lyde og bogstaver og dele ord i stavelser samt i at læse og skrive sammenhængende tekster. Materialerne retter sig mod forskellige målgrupper, herunder indsatte i fængsler og indvandrere. Projektet organiseres af centeret Luki-tuki-keskus ved den ovenfor nævnte folkehøjskole Turun Kristillinen Opisto (jf. afsnit 4.5.2.2) og finansieres af det finske spilleautomatforbund Raha-automaattiyhdistys (RAY).

4.5.2.5 Afsluttet projekt vedrørende udvikling af psykosociale og kognitive færdigheder blandt voksne med læse- og skrivevanskeligheder Den finske stiftelse for rehabilitering, Kuntoutussäätiö, gennemførte i årene 1996-2000 et forsøg, som gik ud på at forbedre de psykosociale og kognitive færdigheder blandt voksne med forskellige typer af vanskeligheder, herunder ordblindhed. ${ }^{164}$ Projektet blev igangsat på initiativ af den tidligere omtalte interesseorganisation for ordblinde, Helsingin seudun erilaiset oppijat ry (HERO), og annonceret i denne organisations medlemsblad samt på Helsinkis arbejdsformidlings hjemmeside. Projektet blev finansieret af det finske spilleautomatforbund Raha-automaattiyhdistys (RAY).

41 deltagere mellem 22 og 61 år deltog i et forløb, som strakte sig over seks måneder. Knap halvdelen af deltagerne var i arbejde, mens resten enten var studerende eller arbejdsløse. Under forløbet mødtes deltagerne i små grupper én gang om ugen. I forbindelse med gruppemøderne indgik blandt andet følgende aktiviteter:

- Diskussion af deltagernes følelser og oplevelser vedrørende deres læse- og skrivevanskeligheder

- Diskussion af forskellige læringsstrategier (visuelle, auditive og kinæstetiske)

- Dramaøvelser

- Kropsøvelser med henblik på at aktivere forskellige områder af hjernen (kinesiologisk program)

- NLP-teknikker (Neurolingvistisk Programmering)

- Afspændingsøvelser

- Visualiseringsøvelser

- Musikterapi

\footnotetext{
${ }^{163}$ Kielikukko 2/2006, pp. 24-25

${ }^{164}$ Haapasalo, S. \& Salomäki, J. (2000). On kuin kivi olisi vierähtänyt sydämeltä. Kokemuksia aikuisten erilaisten oppijoiden ryhmäkuntoutuksesta. [„It's like rolling a stone down from one’s heart. Experiences from group rehabilitation of adult diverse learners“]. Helsinki: Kuntoutussäätiön tutkimuksia 64.
} 
- Introduktion af computerbaserede træningsprogrammer.

Derudover kunne deltagerne indgå i en læse- og skrivetræningsgruppe, hvis de ønskede det. Efter forløbet blev deltagerne spurgt om deres vurdering af deres udbytte. $95 \%$ af deltagerne var tilfredse med forløbet som helhed. 82 \% oplevede, at deres færdigheder i at klare arbejde eller studier var forbedret. Ni måneder efter afslutningen af forløbet blev deltagerne på ny spurgt om deres vurdering. Alle deltagerne på nær to gav udtryk for, at projektet havde haft en positiv indflydelse på deres liv.

\subsubsection{Tilbud om læserådgivning for voksne (projekt Lukineuvola)}

Siden 2005 har der været etableret „læserådgivninger“ med det formål at informere om ordblindhed og tilbyde hjælp til ordblinde. Der er nu etableret læserådgivningscentre i følgende fire byer i Finland: Helsinki, Vaasa, Tampere og Joensuu. Her kan brugerne blandt andet stifte bekendtskab med forskellige slags materialer om læse-, skrive- og indlæringsvanskeligheder og få støtte og vejledning i spørgsmål vedrørende læse- og skrivevanskeligheder, fx i forbindelse med studier og arbejde. Det er også muligt at træne med særlige computerprogrammer og at blive testet i rådgivningen. Projektet er finansieret af Den Europæiske Socialfond (ESF) og det finske undervisningsministerium. ${ }^{165}$

Projektet ligger i forlængelse af det arbejde, som blev udført i forbindelse med en tidligere informationskampagne (projekt Luki-bussi, som beskrives i afsnit 4.5.2.7 nedenfor). ${ }^{166}$

\subsubsection{Afsluttet informationskampagne om ordblindhed (projekt Lukibussi).}

Projekt Lukibussi var en omfattende kampagne, som havde til formål at udbrede kendskab til ordblindhed samt at etablere netværk for eksperter inden for området. Målgrupperne for kampagnen var blandt andet ordblinde personer, forældre, lærere, ansatte inden for social- og sundhedsvæsenet samt repræsentanter for erhvervslivet. ${ }^{167}$ I perioden 2002-2004 kørte der i hele Finland to såkaldte „ordblindebusser“ (finsk: lukibussi) rundt og informerede om ordblindhed. I forbindelse med projektet blev der etableret en række nye informationscentre og interesseorganisationer for ordblinde.

Projektet foregik i et samarbejde mellem en række forskellige organisationer, herunder interesseorganisationen Erilaisten oppijoiden liitto (svensk: Förbundet för all inlärning). Projektet blev administreret af det

\footnotetext{
${ }^{165}$ Jf. nyhedsbrevet LukSitkO 1/2006

${ }^{166}$ Opetushallitus (2006). Lukineuvola - Dyslexia Service and Advice Centre for People with Learning Difficulties FI-47. (Dokumentet findes som en del af det finske informationsmateriale på følgende DVD: NAV NONITE - Nordnorsk IKT-senter (2006). Nordisk informations DVD om teknologisk laese- og skrivestøtte i arbejdslivet. Bodø: NAV NONITE - Nordnorsk IKT-senter.)

${ }^{167}$ Jf. projektets website: http://www.lukibussi.net/swe/info/
} 
finske forbund af kommuner (finsk: Suomen Kuntaliitto) og finansieret af Den Europæiske Socialfond (ESF).

\subsubsection{Støtteforanstaltninger i uddannelsessammenhæenge}

4.5.3.1 Rammer for støtteforanstaltninger i erhvervsuddannelser

Ifølge lov om erhvervsuddannelse gives der specialundervisning til studerende, som har behov for særskilt undervisning som følge af handicap, sygdom, forsinket udvikling eller anden årsag. For sådanne studerende skal der udarbejdes en individuel plan for, hvordan undervisningen skal tilrettelægges. ${ }^{168}$ Inden for specialundervisningen skal undervisningen tilrettelægges, således at den studerende i så stor udstrækning som muligt opnår samme kompetence som i anden form for erhvervsuddannelse. ${ }^{169}$

4.5.3.2 Mulighed for screening af læse- og stavefærdigheder i erhvervsuddannelser

Med støtte fra blandt andet det finske undervisningsministerium og Den Europæiske Socialfond (ESF) har Niilo Mäki Instituttet ved Universitetet i Jyväskylä i løbet af de sidste par år udviklet en række nye test med henblik på screening for og diagnosticering af ordblindhed (dysleksi). Screeningsmaterialet er standardiseret i forhold til elever i erhvervsuddannelser og grundskolens 9 . klasse. ${ }^{170}$

Der foreligger ikke oplysninger om, i hvilket omfang de nye test anvendes i erhvervsuddannelserne.

4.5.3.3 Tidligere undersøgelse af omfang af screening på erhvervsuddannelser

I 2001 blev der i forbindelse med projekt NÄYTTÖ (jf. afsnit 4.5.3.5 nedenfor) gennemført en undersøgelse af 17 erhvervsskolers indsats i forhold til at identificere ordblinde deltagere. ${ }^{171}$ I de fleste af disse skoler blev der gennemført interviews med deltagerne ved starten af uddannelsesforløbet, og ti af skolerne anvendte desuden spørgeskemaer. Kun fem af skolerne screenede deltagerne for ordblindhed. 11 af skolerne have en speciallærer, som primært arbejdede i en specialklasse for deltagere med særlige behov. I praksis var det de almindelige klassers egne lærere, som

\footnotetext{
${ }^{168} \S 20$ i Lag om yrkesutbildning 21.8.1998/630 (http://www.finlex.fi/sv/laki/ajantasa/1998/19980630)

${ }^{169}$ § 8 Förordning om yrkesutbildning 6.11.1998/811 (http://www.finlex.fi/sv/laki/ajantasa/ 1998/19980811)

${ }^{170}$ Holopainen, L., Kairaluoma, L., Nevala, J., Ahonen, T., \& Aro, M. (2004). Lukivaikeuksien seulontamenetelmä nuorille ja aikuisille. [„Dyslexia screening tool for youth and adults“]. Jyväskylä: University of Jyväskylä, Niilo Mäki Institute.

${ }^{171}$ Pajukoski, S. \& Rinne, E. (2002). Erilaiset oppijat näytöissä, osaraportti I. Erilaisen oppijan tunnistaminen sekä tuki- ja ohjaustoimet ammatillisessa peruskoulutuksessa. [„Diverse learners in skills demonstrations, project report I. Recognising diverse learner and support and counselling methods in vocational secondary school“]. Helsinki: Helsingin seudun erilaiset oppijat ry (HERO).
} 
havde størstedelen af ansvaret for at identificere deltagere med ordblindhed.

4.4.3.4 Igangværende projekt med henblik på udarbejdelse af håndbog om støtteforanstaltninger for unge ordblinde

Der er ved at blive udarbejdet en håndbog for lærere om, hvordan unge ordblinde kan støttes. Niilo Mäki Instituttet ved Universitetet i Jyväskylä står i samarbejde med blandt andet flere erhvervsskoler for udarbejdelsen af håndbogen, som forventes udgivet i slutningen af 2007. Arbejdet med håndbogen koordineres af det finske undervisningsministerium og støttes økonomisk af ESF. ${ }^{172}$

4.5.3.5 Afsluttet udviklingsprojekt vedrørende særlig tilrettelæggelse af undervisning og eksamen for ordblinde (projekt NÄYTTÖ)

I perioden 2001-2004 blev der inden for erhvervsuddannelserne gennemført et projekt med henblik på at støtte elever med særlige behov, herunder ordblinde elever, specielt i forbindelse med eksamener, hvor eleverne skal demonstrere deres erhvervsfaglige færdigheder. Mottoet for projektet var, at eleverne skulle gives mulighed for at demonstrere, hvad de kunne, og ikke, hvad de ikke kunne. Projektet blev benævnt NÄYTTÖ (hvilket i denne sammenhæng kan oversættes med „demonstration“). Som led i projektet blev der udviklet screenings- og undervisningsmetoder samt en række undervisningsmaterialer, som underviserne nu kan benytte. Der blev endvidere afholdt kurser for undervisere og arbejdsgivere og etableret ekspert-netværk.

Projektet blev gennemført i Helsinki-området på tre erhvervsskoler med 2200 elever fra tekniske erhvervsuddannelser, 1800 elever fra socialog sundhedsområdet og 1250 fra service-området. De skoler, som deltog i projektet, screenede alle elever ved starten af skoleåret med en læse- og stavetest, der var standardiseret i forhold til 12-årige. Der blev udarbejdet individuelle studieplaner og givet specialundervisning, hvis der var behov for det. Der blev i retningslinjerne for projektet lagt vægt på, at ordblinde elever skulle have mulighed for at anvende alternative måder til at udtrykke deres viden. De skulle blandt andet have mulighed for at bruge stavekontrol, og forekomst af stavefejl skulle ikke tages i betragtning ved vurdering af skriftlige opgaver. ${ }^{173}$ Projektet blev finansieret af Den Europæiske Socialfond (ESF) og administreret af det finske undervisningsministerium.

\footnotetext{
${ }^{172}$ Ojanen, E. (2006). Finnish data for the Nordic pre-project. Jyväskylä: University of Jyväskylä, Niilo Mäki Institute. (Upubliceret rapport udarbejdet i forbindelse med nordisk forprojekt om voksne kortuddannedes læsning).

${ }^{173}$ Pajukoski, S., Tuomi, A. \& Koskinen, S. (2004). NÄYTTÖ - mahdollisuus erilaiselle oppijalle. Opas ammatillisen peruskoulutuksen opettajalle, työpaikkaohjaajalle ja opiskelijalle. [„,Demonstration, a possibility for a diverse learner. Guidebook for teachers of vocational schools, supervisor in the work place and the students"]. Helsinki: Helsingin seudun erilaiset oppijat ry (HERO). (http://www.saunalahti.fi/mik4/naytto-projekti/tiedostot/hero.pdf)
} 
4.5.3.6 Afsluttet udviklingsprojekt vedrørende forbedring af læse- og skrivefærdigheder blandt finlands-svenske unge (Projekt SF-SOL)

Södra Finlands Skriv- och Läsprojekt (SF-SOL) rettede sig mod finlandssvenske unge og strakte sig over perioden 2000-2003. ${ }^{174}$ Fire erhvervsskoler og et gymnasium deltog i projektet, som blandt andet havde til formål:

- At forhindre, at elever klarer sig dårligt eller afbryder deres uddannelse på grund af „indlæringsvanskeligheder“

- At alle elever kan identificere deres egen indlæringsstil og får viden om eventuelle læse- og skrivevanskeligheder

- At udvikle metoder, således at lærerne kan identificere elever med læse- og skrivevanskeligheder og eventuelle andre „,indlæringsvanskeligheder“.

I perioden 2000-2002 deltog alle førsteårselever på de involverede skoler i test, der afdækkede deres færdigheder i ordkendskab, læseforståelse, afkodning og stavning. Desuden blev der indsamlet materiale om deltagernes indlæringsstil. ${ }^{175}$

Projektet blev ledet af den svensksprogede afdeling af interesseorganisationen HERO (HEROSAK) og blev finansieret af Den Europæiske Socialfond (ESF).

Der er udgivet flere rapporter om projektet, hvor blandt andre nogle af de involverede lærere og elever videregiver deres indtryk og erfaringer. Der synes at være stor variation mellem tiltagene på de enkelte skoler, men erfaringerne forekommer overvejende at være positive. ${ }^{176}$

\subsubsection{Scerlige tilbud for indvandrere}

\subsubsection{Rammer for undervisning af indvandrere}

For generelle informationer om tilbud og tiltag for indvandrere henvises der til det finske arbejdsministeriums website. ${ }^{177}$

Det kan specielt bemærkes, at Undervisningsministeriet i 2006 som noget nyt har publiceret en række anbefalinger for undervisning af voksne analfabeter. ${ }^{178}$

\footnotetext{
${ }^{174}$ Jf. beskrivelse af projektet på HERO’s website: http://www.lukihero.fi/

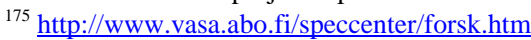

${ }^{176}$ HERO/Herosak (2003). SF-SOL. Södra Finlands Skriv- och Läsprojekt 2001/2002. Helsinki: HERO/Herosak.

${ }^{177}$ http://www.mol.fi/mol/se/04_migration/index.jsp

${ }^{178} \mathrm{http}: / /$ www.oph.fi/frontpage.asp?path=1
} 
4.5.4.2 Igangværende udvikling af internetservice for personer med læseog skrivevanskeligheder, herunder indvandrere (projekt Verkko-Lukki)

Det i afsnit 4.5.2.4 omtalte projekt Verkko-Lukki sigter mod at skabe en internet-service med træningsøvelser for personer med læse- og stavevanskeligheder. Nogle af øvelserne er specielt designet til indvandrere og fokuserer blandt andet på strukturerne i det finske sprog. ${ }^{179}$

\subsection{Sverige}

\subsubsection{Sammenfatning vedrørende svenske tilbud og tiltag}

I Sverige eksisterer der en række forskellige tilbud om læse- og skriveundervisning for voksne, blandt andet på folkehøjskoler (jf. 4.6.2.1), på private virksomheder (jf. 4.6.2.2) og i oplysningsforbund (jf. 4.6.2.3). Der er inden for disse forskellige regier blevet gennemført udviklingsprojekter og rapporteret erfaringer herfra. Derudover findes der særlige undervisningstilbud for voksne med læse- og skrivevanskeligheder inden for den kommunale voksenuddannelse, KomVux (jf. 4.6.3.1).

I forhold til arbejdsløse er der rapporteret flere eksempler på særlige tiltag. Der er blandt andet gennemført en større, systematisk undersøgelse af effekten af deltagelse i et 20 uger langt læse-skrivekursus for arbejdsløse med læse- og skrivevanskeligheder (jf. 4.6.2.4). Undersøgelsen viste, at deltagerne i læse-skrivekurset gik signifikant mere frem på mål for stavning, afkodning, hukommelse og selvtillid end en kontrolgruppe, der ikke deltog i læse-skrivekurset.

\subsubsection{Tilbud og tiltag i arbejds- og fritidssammenhæenge}

4.6.2.1 Tilbud om læse-skriveundervisning og vejledning på „folkhögskolor“

I Sverige har folkehøjskolerne (svensk: folkhögskolorna) været førende, hvad angår udvikling af kurser for kortudannede voksne med læse- og skrivevanskeligheder. Der findes nu omkring 35 folkehøjskoler, som har kurser for personer med læse- og skrivevanskeligheder/ordblindhed. ${ }^{180}$

Kursusperioden strækker sig oftest over et til to år, og vægten lægges på læse- og skrivetræning. Undervisning for voksne ordblinde på folkehøjskoler finansieres typisk af offentlige midler via arbejdsformidlingen. ${ }^{181}$

\footnotetext{
${ }^{179}$ Kielikukko 2/2006, pp. 24-25

${ }^{180}$ Jf. folkhögskolornas website: http://www.folkhogskola.nu/Courses.asp?TAB=LongContent\& LONGCATEGORY ID $=52$

${ }^{181}$ Lavås, I. (2006). Svenska data i förundersökning av kortutbildade med läs- och skrivsvårigheter. Härnösand: Mittuniversitetet. (Upubliceret rapport udarbejdet i forbindelse med nordisk forprojekt om voksne kortuddannedes læsning).
} 
Som et eksempel kan nævnes Löftadalens folkhögskola, som udbyder et kursus for voksne med læse-skrivevanskeligheder. I kurset indgår intensiv undervisning i læsning, skrivning og matematik på små hold. Desuden indgår undervisning i samfunds- og naturorientering. Under kurset kan deltagerne låne en bærbar computer, som indgår som hjælpemiddel i undervisningen. ${ }^{182}$ Positive og negative erfaringer med brug af ITbaserede hjælpemidler og undervisningsmidler på et af folkehøjskolens tidligere kurser er beskrevet af nogle af skolens lærere i en rapport. ${ }^{183}$

Et andet eksempel er Brunnsviks folkhögskola, som udbyder et alment kursus med en særlig læse- og skriveprofil.184 Kurset retter sig mod voksne med læse- og skrivevanskeligheder og indebærer, at deltagerne to af ugens dage følger undervisning inden for følgende områder:

- læse- og skrivetræning

- lektiehjælp og studieteknik

- anvendelse af hjælpemidler

- samfundsorientering.

De øvrige dage følger deltagerne undervisning i svensk, engelsk og matematik.

Ved Brunnsvik folkhögskola findes desuden „Läs- och skrivpedagogiskt centrum“, som ikke blot kan benyttes af deltagere på skolens kurser, men også generelt af voksne med læse- og skrivevanskeligheder, faglige organisationer og lærere inden for voksenundervisningen. 185 Dette center arbejder blandt andet med:

- Information, rådgivning og kurser med arbejdslivet som specialområde

- Støtte og vejledning til voksne studerende

- Diagnosticering af unge og voksne med læse- og skrivevanskeligheder

- Tekniske hjælpemidler.

Centret er oprettet i samarbejde med Landsorganisationen (LO), Arbetarnas bildningsförbund ( $\mathrm{ABF}$ ) og Förbundet funktionshindradede med läsoch skrivsvårigheter (FMLS).

\footnotetext{
${ }^{182}$ Jf. Löftadalens folkhögskolas website: http://www.folkhogskola.nu/School.asp?TAB= Long\&SCHOOL_ID=152\&TAB2=LongDetail\&LONGCOURSE_ID=90869

${ }^{183}$ Kennemyr, I. Ridderstad, P. \& Tyreus, S. (2002). Datorn - kompensatoriskt hjälpmedel och stöd vid inlärning för vuxna elever med läs- och skrivsvårigheter. Stockholm: Folkbildingsrådet. (http://www.resurs.folkbildning.net/download/515/loftadalendatornhjalpmede.pdf)

${ }^{184} \mathrm{Jf}$. Brunnsviks folkhögskolas website: http://www.folkhogskola.nu/School.asp?TAB=Long\&SCHOOL_ID=29\#course89621

${ }^{185} \mathrm{Jf}$. Brunnsviks folkhögskolas website: http://www.brunnsvik.se/index2.html
} 
4.6.2.2 Tilbud om læse- og skrivekurser på virksomheder

I Sverige har blandt andet virksomheden Volvo i en årrække tilbudt kurser for medarbejdere med læse- og skrivevanskeligheder. Man har informeret om ordblindhed og tilbudt alle de medarbejdere, som kunne genkende sig selv i beskrivelsen, læse- og skriveundervisning i arbejdstiden. I afsnit 5.4 gives der en nærmere beskrivelse af undervisningen for medarbejdere i en af Volvos afdelinger.

4.6.2.3 Tilbud for voksne med læse- og skrivevanskeligheder inden for oplysningsforbund

Inden for oplysningsforbundet Arbetarnas Bildningsförbund ( $A B F$ ) findes der tilbud om deltagelse i såkaldte „studiecirklar“ for personer med læseog skrivevanskeligheder. ${ }^{186}$

Som et eksempel på et særligt tiltag i dette regi kan fremhæves EUprojektet Focus Alfa, som blandt andet ABF Kronoberg deltager i. Projektet retter sig mod voksne ordblinde (dyslektikere) og går ud på at afprøve nye metoder og kompensatoriske IT-hjælpemidler i forbindelse med indlæring af fremmedsprog. I den svenske del af projektet, som ABF er involveret $\mathrm{i}$, fokuseres der på ordblindes tilegnelse af engelsk. De fleste af deltagerne er voksne i arbejde. På projektets hjemmeside findes der flere foreløbige forløbsrapporter, men ingen endelig rapport om erfaringerne fra projektet. ${ }^{187}$

4.6.2.4 Afsluttet undersøgelse af effekt af kursus for arbejdsløse med læse- og skrivevanskeligheder

Jensen, Lindgren, Andersson, Ingvar \& Levander (2000) gennemførte en undersøgelse af effekten af et særligt tilrettelagt kursusforløb for arbejdsløse med læse- og skrivevanskeligheder. ${ }^{188}$ I dette forløb deltog 60 arbejdsløse svenskere, som gennemsnitligt havde 10,1 års skolegang bag sig og gennemsnitligt havde været arbejdsløse i 26,2 måneder. Forløbet var et 20 uger langt fuldtidskursus, som sigtede mod at forbedre deltagernes læsning, skrivning, hukommelse og selvtillid. Under kurset blev der blandt andet arbejdet med procesorienteret skrivning, læsevaner, mundtlig fremlæggelse, brug af tekstbehandling og stavekontrol, hukommelsestræning og viden om arbejdsmarkedet.

Før og efter kurset blev der gennemført test af deltagernes færdigheder i blandt andet læsehastighed, afkodning, stavning og hukommelse. Endvidere blev deltagerne før og efter forløbet interviewet og besvarede spørgeskemaer, som blandt andet blev anvendt til at vurdere deltagernes selvtillid. En kontrolgruppe på 16 personer deltog i før- og eftermålingen. Denne gruppe deltog ikke i læse- og skriveundervisning, men i forskelli-

\footnotetext{
${ }^{186}$ http://www.abf.se/

${ }^{187}$ http://www.focusalfa.se/

${ }^{188}$ Jensen, J., Lindgren, M., Andersson, K., Ingvar, D.H. \& Levander, S. (2000). Cognitive Intervention in Unemployed Individuals With Reading and Writing Disabilities. Applied Neuropsychology, 7(4), 223-236.
} 
ge andre aktiviteter for arbejdsløse. Undersøgelsen viste, at deltagerne i forsøgsundervisningen sammenlignet med kontrolgruppen gik signifikant mere frem på målene for stavning, afkodning, hukommelse og selvtillid vedrørende egne færdigheder i læsning og skrivning. Seks måneder efter forløbet havde $26 \%$ af forsøgsdeltagerne fået arbejde, mens andre $28 \%$ var begyndt på en uddannelse. Det var ikke muligt at opnå sammenlignelige data fra kontrolgruppen vedrørende påbegyndelse af arbejde eller uddannelse, men der blev foretaget en sammenligning med data fra andre arbejdsløse, som deltog i forskellige aktiviteter. På basis af denne sammenligning vurderer forfatterne til rapporten om undersøgelsen, at antallet af forsøgsdeltagere, der var begyndt på arbejde eller uddannelse, var meget højt.

4.6.2.5 Særlige hjælpemidler for læsehandicappede på arbejdsmarkedet

Der findes forskellige teknologiske hjælpemidler, som kan støtte læsehandicappede voksne i arbejdssammenhæng. Fx er der udviklet og afprøvet et særligt IT-baseret staveprogram, Stava Rätt, som blandt andet er blevet afprøvet på voksne i arbejde. ${ }^{189}$ For en nærmere beskrivelse af mulighederne for at få teknologisk læse- og skrivestøtte i arbejdslivet i Sverige henvises der til en nyligt udgivet nordisk DVD med tilhørende informationsmateriale. ${ }^{190}$ (Materialet beskrives nærmere i afsnit 4.7 om fælles-nordiske tiltag).

4.6.2.6 Afsluttede udviklingsprojekter vedrørende støtteforanstaltninger til ordblinde arbejdssøgende

Den svenske arbejdsmarkedsstyrelse („Arbetsmarknadsstyrelsen“) har udgivet flere rapporter, hvori der beskrives erfaringer fra særlige projekter med fokus på ordblinde arbejdssøgende. Fx gennemførtes der på arbejdsformidlingen i Uppsala et projekt, der blandt andet sigtede mod at give sagsbehandlere øget viden om ordblindhed (dysleksi), således at de kunne henvise potentielt ordblinde klienter til nærmere udredning og diagnosticering. ${ }^{191}$

Endvidere har Arbetsförmedlingen Rehabilitering i Lund gennemført og rapporteret et projekt, som havde til formål at udvikle ressourcer og kompetencer blandt ordblinde (dyslektikere). ${ }^{192}$ I projektet deltog 28 arbejdssøgende, som af enten en specialpædagog eller en psykolog var diagnosticeret som ordblinde (dyslektikere). Knap halvdelen havde ingen uddannelse ud over grundskolen. I forbindelse med projektet fik delta-

\footnotetext{
${ }^{189}$ Pousette, S., Berns, T. \& Wirstad, J. (1999). AMS - Stava Rätt. Stockholm: Arbetsmarknadsservice.

${ }^{190}$ NAV NONITE - Nordnorsk IKT-senter (2006). Nordisk informations DVD om teknologisk læse- og skrivestøtte i arbejdslivet- 2002-2004. Projektrapport. Bodø: NAV NONITE - Nordnorsk IKT-senter.

${ }^{191}$ Alm, J. (1996). The dyslexia project at the employability institute of Uppsala. Vtu, 7. Stockholm: Arbetsmarknadsstyrelsen. (http://www.tuffa.nu/rapporter\%5CVtu_1996_7.pdf)

${ }^{192}$ Fermischek, V. \& Åhlund, G. (2004). Dyslexiprojektet. Hjälpmedel - Anpassning - Skräddarsydda lösningar. Stockholm: Arbetsmarknadsstyrelsen.
} 
gerne under vejledning mulighed for at afprøve forskellige IThjælpemidler, som kunne støtte dem i forbindelse med eventuelt kommende arbejde eller uddannelse, $\mathrm{fx}$ talesyntese, stavekontrol og digitale ordbøger. En stor del af deltagerne i projektet var seks måneder senere kommet i arbejde eller uddannelse.

\subsubsection{Støtteforanstaltninger i uddannelsessammenhæenge}

4.6.3.1 Tilbud om læse- og skriveundervisning inden for den kommunale voksenuddannelse

Den kommunale voksenuddannelse skal ifølge den officielle forordning støtte voksnes læring med udgangspunkt i den enkeltes behov og forudsætninger. Støtten kan blandt andet have form af undervisning og vejledning. ${ }^{193}$

Roos (2006) har foretaget en analyse af tilbud til voksne med læse- og skrivevanskeligheder inden for den kommunale voksenuddannelse. ${ }^{194} \mathrm{I}$ sin rapport påpeger hun, at personer med læse- og skrivevanskeligheder i forskellige officielle „styrdokument“ er genstand for særlig opmærksomhed og regnes som en gruppe, som kræver specialpædagogisk kompetence. Hun påpeger endvidere, at mange kommuner har foretaget særlige indsatser for denne gruppe. Disse indsatser er imidlertid primært blevet gennemført i segregerende former ved siden af den ordinære uddannelse, hvilket kritiseres af mange speciallærere, som har deltaget i Roos’ undersøgelse.

Inden for den kommunale voksenuddannelse (KomVux) udbydes læseog skriveundervisning, som kan kompletteres med fag fra KomVux' ordinære kursusudbud. Kurserne finansieres hovedsageligt via offentlige midler fra arbejdsformidling og forsikring (svensk: försäkringskassa). ${ }^{195}$

Et eksempel på et tilbud inden for KomVux er den såkaldte „dyslexilinje“ ved KomVux Mimer i Umeå. Tilbuddet retter sig specielt mod ordblinde (dyslektikere) og består af undervisning i det svenske sprogs opbygning og stavning, træning af læsehastighed og ordkendskab, anvendelse af studieteknikker og IT-baserede hjælpemidler. ${ }^{196}$

\footnotetext{
${ }^{193}$ Förordning (2002:1012) om kommunal vuxenutbildning (http://www.skolverket.se/sb/d/155/a/1032\#paragraphAnchor1)

${ }^{194}$ Roos, E.E. (2006). Aldrig för sent. Verksam pedagogik för vuxna med läs- och skrivsvårigheter. Växjö: Växjö Universitet, Institutionen för Pedagogik. (http://www.sit.se/download/PDF/Dyslexi/Aldrig_för_sent,_slutvers.pdf)

${ }^{195}$ Lavås, I. (2006). Svenska data i förundersökning av kortutbildade med läs- och skrivsvårigheter. Härnösand: Mittuniversitetet. (Upubliceret rapport udarbejdet i forbindelse med nordisk forprojekt om voksne kortuddannedes læsning).

${ }^{196}$ Jf. KomVux Mimers website: http://www.skola.umea.se/komvuxmimer/kursutbud/dyslexi.4.13c1b69101a982ca2a800063480.html
} 
4.6.3.2 Tilbud om støtte og vejledning i „lärcentra“

Der findes „lärcentra“ mange steder i Sverige. De drives både i kommunalt regi, inden for folkeoplysningen og fagforbund. ${ }^{197}$ Benævnelsen af centrene kan variere. De kan fx kaldes „kompetenscentrum“, „studiecentrum“ eller „högskolenhet“. De enkelte centre fungerer som studiemiljø og mødested for voksne, der er i gang med en uddannelse. I disse centre er der adgang til vejledning, lokaler og tekniske faciliteter som fx computere med Internet og specielle programmer for personer med læse- og skrivevanskeligheder.

\subsubsection{Scerlige undervisningstilbud for indvandrere}

4.6.4.1 Rammer for undervisning af indvandrere

For generelle informationer om svenskundervisning for indvandrere henvises til Regeringskansliets website. ${ }^{198}$

4.6.4.1.1 Afsluttet udviklingsprojekt for indvandrere med læsevanskeligheder

Der er udviklet særlige undervisningstilbud for indvandrere med læsevanskeligheder på flere folkehøjskoler, herunder Botkyrka folkhögskola. ${ }^{199}$ Nogle af denne skoles lærere har i en rapport beskrevet erfaringer fra udviklingen af et undervisningsforløb for en gruppe elever med svensk som andetsprog, som oplevede at læse og skrive dårligere end de andre elever. ${ }^{200}$ I projektet blev der blandt andet givet en struktureret gennemgang af de svenske staveregler. Deltagerne læste tekster med henblik på at træne ordkendskab og læseforståelse og skrev logbog med henblik på at træne fri skriftlig fremstilling. Erfaringerne fra projektet beskrives som overvejende positive.

\subsection{Fælles-nordiske tiltag}

\subsubsection{Fcelles-nordisk informations-DVD om lase- og skrivehjæelpemidler til ordblinde på arbejdsmarkedet}

Der er gennemført et fælles nordisk informationsprojekt om læse- og skrivehjælpemidler til ordblinde på arbejdsmarkedet. I alt fem nordiske lande har deltaget. I forbindelse med projektet er der udgivet en informations-DVD, der har til formål at udbrede kendskabet til og anvendelsen af

\footnotetext{
${ }^{197}$ http://www.larcentra.se

198 http://www.regeringen.se/sb/d/2508/a/19974;jsessionid=a9SJzIUaiBY8

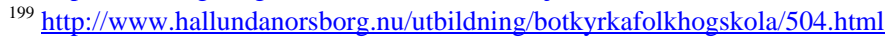

${ }^{200}$ Botkyrka folkhögskola (2003). Projektmaterial. Läs- och skrivsvårigheter hos Sv2-elever inom folkhögskolan. Stockholm: Folkbildingsrådet.

(http://www.resurs.folkbildning.net/download/197/botkyrka_fhs.pdf)
} 
teknologiske hjælpemidler på arbejdsmarkedet. ${ }^{201}$ Hjælpemidlerne består primært i anvendelse af computere og brug af syntetisk tale til oplæsning af tekster samt særlige programmer til stavning og skrivning. DVD'en gennemgår ud over de computerbaserede hjælpemidler en række hjælpemidler til løsning af andre læse- og skriveudfordringer i hverdagens arbejdsliv. Det gælder fx anvendelse af GPS til navigation, samt mobiltelefoner, PDA, diktafoner og andet udstyr.

DVD'en indeholder blandt andet interviews med mennesker, der fortæller om deres konkrete brug af it-hjælpemidler i arbejdet. Derudover er der en række interviews med fagfolk, der fortæller om brug af IThjælpemidler i de nordiske lande. Endelig beskrives en lang række teknologiske hjælpemidler gennem videopræsentationer af deres funktioner. DVD'en indeholder desuden et omfattende skriftligt materiale i form af rapporter og artikler fra alle fem lande.

Projektet er finansieret af Nordisk Udviklingscenter for Handicaphjælpemidler og gennemført i et samarbejde mellem blandt andet arbejdsmarkedsstyrelser, hjælpemiddelinstitutter og ordblindeorganisationer i Sverige, Danmark, Norge, Finland og Island.

\subsubsection{Dansk-norsk erfaringsudveksling vedrørende undervisning på arbejdspladser}

Der er i 2006 påbegyndt et mindre nordisk projekt, hvor en gruppe danske og norske lærere og konsulenter mødes og udveksler erfaringer med læse- og skriveundervisning på virksomheder. ${ }^{202}$ Projektet skal blandt andet munde ud i en samling af eksempler på „best practice“ og en liste over, hvad man skal gøre og undlade at gøre i forbindelse med læse- og skriveundervisning på virksomheder. Projektet er finansieret af programmet Nordplus Voksen.

\subsection{Diskussion vedrørende tilbud og tiltag}

I det foregående er der givet beskrivelser af en række nordiske tilbud og tiltag for voksne med utilstrækkelige læse-, skrive- og stavefærdigheder i de nordiske lande. I det følgende gives nogle kommentarer til det billede, der tegner sig.

Oversigten i kapitel 4 viser, at der findes mange forskellige typer af tilbud og tiltag i de enkelte nordiske lande, både i arbejds- og uddannelsesrelaterede sammenhænge. Overordnet kan der nævnes følgende hovedtyper af tilbud og tiltag:

\footnotetext{
${ }^{201}$ NAV NONITE - Nordnorsk IKT-senter (2006). Nordisk informations DVD om teknologisk læse- og skrivestøtte i arbejdslivet. Bodø: NAV NONITE - Nordnorsk IKT-senter.

${ }^{202}$ News from $V O X$, vol. 5(5), oktober 2006, p. 3.
} 
1. Tilbud om lcese- og skrivekurser for voksne med utilstrcekkelige laesefcerdigheder

Sådanne kurser foregår ofte på institutioner, der har specialiseret sig i undervisning for voksne, fx voksenuddannelsescentre, oplysningsforbund eller folkehøjskoler. I nogle tilfælde foregår undervisningen på deltagernes arbejdspladser, men lærerkræfterne er typisk hentet fra institutioner som de ovenfor nævnte. Specielt i Finland synes det at være almindeligt, at læse- og skrivekurser igangsættes af interesseorganisationer for ordblinde.

2. Støtteforanstaltninger i uddannelsessammenhæenge for personer med lase-, stave- og skrivevanskeligheder

Typiske støtteforanstaltninger er særlige IT-hjælpemidler, studiematerialer på lydmedie, støtteundervisning og særlige vilkår til eksaminer (fx forlænget tid). Disse støtteforanstaltninger er især rettede mod deltagere med ordblindhed/dysleksi. På nogle uddannelsesinstitutioner foretages der screening med henblik på at identificere sådanne deltagere, men det er vanskeligt at få et overblik over, i hvilket omfang der findes tilbud om screening på de enkelte uddannelser. Praksis synes at variere betydeligt mellem de enkelte uddannelsesinstitutioner.

3. Scerlige tilbud for indvandrere m.fl.

I alle de nordiske lande findes der grundlæggende sprogundervisning for personer med et andet modersmål end majoriteten i landet. I nogle lande findes der derudover særlige tiltag, der retter sig specielt mod at forbedre læse-, skrive- og IT-færdighederne hos denne gruppe, lige som der er gennemført enkelte udviklingsprojekter inden for dette område.

Det forekommer umiddelbart oplagt, at der kan finde en gensidig inspirationsudveksling sted mellem de enkelte lande, hvad angår tilbud og tiltag inden for disse områder. Som det vil fremgå af det følgende, kan det imidlertid være problematisk at vurdere, hvilke tiltag der er værd at lade sig inspirere af. Dette hænger sammen med, at der i mange tilfælde ikke foreligger overbevisende dokumentation for effekten af de beskrevne tiltag.

Nogle tiltag er beskrevet i artikler, som er baserede på interviews med en eller flere af de involverede lærere og eventuelt nogle af deltagerne. Sådanne artikler kan naturligvis medvirke til at udbrede kendskabet til et givent tiltag, men kan ikke siges at give noget pålideligt grundlag for at foretage en vurdering af, om det pågældende tiltag er bedre end så mange andre tiltag.

I andre tilfælde foreligger der relativt omfattende evalueringsrapporter, men oftest er effekten af tiltagene kun blevet målt ved at spørge deltagerne om deres oplevelse af udbyttet. Det typiske resultat af sådanne spørgeundersøgelser er, at hovedparten af de deltagere, som ikke er faldet 
fra undervejs i et givet undervisningsforløb, giver udtryk for, at de selv oplever at have fået forbedret deres selvtillid og deres læse- og skrivefærdigheder gennem tiltaget. Det er fx tilfældet i en norsk undersøgelse af AOF's læse-skrivekurser (4.3.2.2.2) og flere evalueringer af det danske FVU-tilbud, hvor deltagerne er blevet interviewet telefonisk (jf. fx 4.3.2.2.2 og 4.2.2.1.2). På grundlag af sådanne undersøgelser kan man imidlertid ikke vide, hvorvidt deltagerne objektivt set faktisk har forbedret deres færdigheder i læsning og skrivning, da det ikke er blevet afdækket, om der er sket en målbar udvikling i disse færdigheder. Det er langtfra givet, at der er en sammenhæng mellem deltagernes oplevede og faktiske udbytte af et undervisningsforløb. I en undersøgelse inden for den kompenserende specialundervisning for ordblinde kunne der således faktisk ikke påvises signifikante sammenhænge mellem deltagernes egne vurderinger af udviklingen i deres færdigheder og den udvikling, der kunne måles ved hjælp af læse- og stavetest (jf. 4.2.2.2.2 - A).

Der er kun rapporteret relativt få nordiske undersøgelser af, hvorvidt deltagelse i tilbud om læse-skriveundervisning har en målbar effekt på voksnes færdigheder. Blandt de få undersøgelser af denne type kan nævnes en svensk undersøgelse af effekten af deltagelse i et kursus særligt tilrettelagt for arbejdsløse med læse- og skrivevanskeligheder (jf. 4.6.2.4). Denne undersøgelse viste, at arbejdsløse, som havde deltaget i et sådant læse-skrivekursus, gik signifikant mere frem på mål for stavning, afkodning, hukommelse og selvtillid end en kontrolgruppe, som havde deltaget i andre aktiviteter for arbejdsløse. Derudover er der gennemført to danske undersøgelser, hvor ordblindes færdigheder blev målt før og efter deltagelse $i$ et forløb inden for den kompenserende specialundervisning (jf. afsnit 4.2.2.2.2). Der blev i begge disse undersøgelser gennemsnitligt fundet beskedne fremgange i deltagernes færdigheder, men markante fremgange for en mindre del af deltagerne. Sådanne undersøgelser kan imidlertid ikke give nogen sikker indsigt $i$, hvilke elementer i undervisningen der har bevirket disse fremgange. Derfor er det vanskeligt at vide, hvad der eventuelt kunne være værd at efterligne i undervisningstilbud for andre voksne.

Mere sikker indsigt kan opnås ved at gennemføre sammenlignende undersøgelser af forskellige undervisningsmetoders effekt på deltageres færdigheder. Som et eksempel kan nævnes en dansk træningsundersøgelse, hvor der blev tilrettelagt to særlige undervisningsforløb for to forskellige grupper af FVU-deltagerne (jf. 4.2.2.1.2). Deltagernes udbytte af disse forløb blev målt og sammenlignet med udbyttet hos en kontrolgruppe, som deltog i et almindeligt FVU-forløb. Sådanne effektundersøgelser af særlig forsøgsundervisning synes at være meget sjældne i Norden, formodentlig fordi de er relativt vanskelige og tidskrævende at gennemføre. Til gengæld opnås der en viden, der kan bruges som grundlag for at vurdere, om de undersøgte metoder er værd af anvende og inkorporere i undervisningstilbud for andre voksne svage læsere. 
I det indsamlede materiale foreligger der oplysninger om enkelte nordiske tiltag, som med rimelighed kan betegnes som kontroversielle. Dette gælder blandt andet det eksisterende islandske kursustilbud for ordblinde voksne, „Tilbage til uddannelse“(„Aftur í nám“), som støttes økonomisk af staten (jf. beskrivelse af tilbuddet i afsnit 4.4.2.1). En væsentlig del af dette kursustilbud består af elementer fra amerikaneren Ron Davis' undervisningsprogram, hvor deltagerne især arbejder med at forme bogstaver og ord i ler. ${ }^{203}$ Det bemærkes, at Davis' teorier om årsagerne til ordblindhed afviger væsentligt fra alment accepteret, forskningsbaseret viden på området. Endvidere foreligger der ikke overbevisende dokumentation eller argumentation for hypotesen om, at ordblinde skulle kunne overvinde deres vanskeligheder ved at arbejde med ler.

Et andet påfaldende eksempel er et afsluttet finsk projekt (jf. afsnit 4.5.2.5), hvor en gruppe voksne foruden læse- og skriveundervisning blandt andet deltog i kinesiologiske kropsøvelser og arbejdede med NLPteknikker (Neurolingvistisk Programmering). Hverken dette projekt eller andre undersøgelser har kunnet dokumentere eller sandsynliggøre, at behandlingsmetoder som kinesiologi og NLP skulle kunne afhjælpe læseog skrivevanskeligheder. ${ }^{204}$

Selv om effekten af et givet tiltag ikke er dokumenteret, kan tiltaget naturligvis godt være en succes i den forstand, at mange brugere derigennem rent faktisk forbedrer deres færdigheder og får lettere ved at klare sig i fx arbejds- eller uddannelsesrelaterede sammenhænge. Ved mange af de beskrevne tiltag gør den manglende dokumentation det imidlertid blot vanskeligt at fastslå, hvornår der er tale om en succes, og hvad der i de enkelte tilfælde er årsag til den eventuelle succes. Hvis et bestemt tiltag opnår et godt ry, kan det skyldes mange forskellige faktorer, fx anvendelsen af en bestemt undervisningsmetode, lærerens engagement eller rekrutteringen af deltagere, og det er derfor vanskeligt at vide, om tiltaget med fordel kan efterlignes og implementeres i andre sammenhænge. Hvis man vil vide, om bestemte metoder fører til bedre resultater end andre metoder, er gennemførelse af effektundersøgelser den mest sikre vej til at opnå denne viden.

Det kan bemærkes, at langt hovedparten af de beskrevne tilbud om læse- og skrivekurser for voksne har en almen karakter. Således er målet for sådanne kurser typisk, at deltagerne opnår en generel forbedring af deres læse-, stave- og skrivefærdigheder. En sådan forbedring er naturligvis ønskværdig for såvel de enkelte deltagere som for samfundet som helhed. Imidlertid ville det faktisk være overraskende, hvis relativt korte kurser kunne kompensere for alt det, som voksne med læse-, stave- og skrive-

\footnotetext{
${ }^{203}$ Metoden er udviklet af Ron Davis og står blandt andet beskrevet i hans bog The Gift of Dyslexia. Bogen findes i dansk oversættelse: Davis, R.D. (2006). Den begavede dyslektiker. København: Klim.

${ }^{204}$ For en kritisk gennemgang af alternative behandlingsmetoder i forhold til ordblinde kan der i nordisk sammenhæng henvises til følgende grundbog: Høien, T. \& Lundberg, I. (1993). Dysleksi. Herning: Specialpædagogisk Forlag. (Denne bog findes på flere nordiske sprog.)
} 
vanskeligheder ikke tidligere har tilegnet sig i løbet af deres skolegang. Man kunne forestille sig, at det bedre kunne betale sig at tilbyde mere målrettede kurser, hvor læse- og skriveundervisningen fokuserede på det område, som deltagerne beskæftigede sig med til daglig i enten arbejdseller uddannelsesmæssige sammenhænge, og hvor tilrettelæggelsen af undervisningen tog udgangspunkt i de krav, som deltagerne mødte i disse sammenhænge. Enkelte eksempler på sådanne tiltag findes da også i oversigten. Således udbydes der på nogle arbejdspladser læse-skrivekurser, der er „skræddersyede“ til bestemte medarbejdergrupper og tager udgangspunkt i arbejdsrelaterede materialer, som fx i det beskrevne projekt for medarbejdere i Greve Kommunes hjemmepleje (jf. 4.2.2.1.2 - E). Ligeledes tager det igangværende danske forsøg med ord- og regneværksteder udgangspunkt i de materialer, der anvendes i deltagernes konkrete uddannelse (jf. 4.2.3.4). Imidlertid foreligger der heller ikke på disse områder undersøgelser, der viser, hvilke metoder der er (mest) effektive. 


\section{Udvalgte nordiske eksempler på læse-skrivekurser for voksne}

\subsection{Indledning}

Forprojektet skal bidrage med beskrivelser af formodet effektive tiltag, der kan reducere eventuelle læse- og stavevanskeligheder. Målet er at indsamle, vurdere og sammenfatte et lovende eksempel fra hvert af mindst tre af de nordiske lande.

I forbindelse med forprojektet er der indhentet data fra tre forskellige tiltag, som vil blive rapporteret i det følgende. Det ene er et dansk eksempel på forberedende voksenundervisning (FVU) i læsning, stavning og skriftlig fremstilling for medarbejdere i en kommunal døgnpleje og køkken/service-afdeling (jf. 5.2). Det andet eksempel er et norsk læse- og skrivekursus inden for Arbeidernes Opplysningsforbund (AOF) (jf. afsnit 5.3). Det tredje eksempel er et tilbud om individuelt tilrettelagt læse- og skriveundervisning på virksomheden Volvo i Sverige (jf. 5.4).

Afslutningsvis diskuteres og kommenteres de tre tiltag (jf. 5.5).

De tre eksempler er efter aftale med repræsentanter for Styregruppen for Voksnes Læring (SVL) delvist anonymiseret. Det fremgår således ikke af beskrivelserne, præcist hvor tiltagene har fundet sted, lige som undervisernes og deltagernes navne ikke nævnes.

\subsection{Et dansk eksempel: Læse-skriveundervisning for kommunalt ansatte medarbejdere}

I det følgende beskrives et dansk eksempel på læse-, skrive- og staveundervisning. Det valgte eksempel er et kursus inden for den forberedende voksenundervisning (FVU). Kurset var rettet specielt mod medarbejdere i en kommunal døgnpleje og køkken/serviceafdeling. Anna Gellert har efter samråd med Undervisningsministeriets FVU-konsulent og amtslige FVU-konsulenter udvalgt dette kursus, observeret en del af undervisningen samt interviewet underviseren og nogle af deltagerne. Den følgende beskrivelse bygger på de oplysninger, der er indsamlet i den sammenhæng.

\subsubsection{Begrundelse for valg af undervisningstiltag}

I Danmark er Forberedende voksenundervisning (FVU) det mest udbredte undervisningstilbud for voksne med utilstrækkelige læse-, stave- og 
skrivefærdigheder. Tilbuddet tiltrækker mange kortuddannede, og da forprojektet netop har fokus på denne gruppe, forekom det oplagt at vælge at studere et tilbud inden for denne ramme. Som nævnt i diskussionsafsnittet 4.8 forekommer det i forhold til kortuddannede voksne relevant at tilbyde målrettede kurser, hvor læse- og skriveundervisningen fokuserer på det område, som deltagerne beskæftiger sig med i arbejdssammenhæng, og hvor tilrettelæggelsen af undervisningen tager udgangspunkt i de krav, som deltagerne møder her. Derfor blev der søgt efter et eksempel på et FVU-tiltag, hvor undervisningen var relateret til deltagernes arbejdsområde. Det konkrete tiltag blev valgt, fordi det lå i forlængelse af et relativt omfattende arbejdsrelateret FVU-projekt, som allerede havde fået en overvejende positiv evaluering. ${ }^{205}$

\subsubsection{Baggrund for undervisningsforløbet}

I efteråret 2005 og foråret 2006 kørte der under overskriften „Kompetenceudviklingsprojekt Skriftlig kommunikation“ i Roskilde Amt adskillige FVU-kurser for medarbejdere i Greve Kommunes Hjemmepleje. I dette projekt blev der i undervisningen især arbejdet med en samarbejdsbog, som alle ansatte i hjemmeplejen skal bruge til at dokumentere deres observationer og handlinger og til at holde sig orienterede om de borgere, der plejes. Projektet i Greve Kommune er blevet af evalueret af et konsulentbureau og står beskrevet i rapporten om forprojektet (jf. afsnit 4.2.2.1.D). Dette projekt var næsten afsluttet ved det nordiske forprojekts start. Imidlertid havde en anden af amtets kommuner videreført ideen og netop startet et nyt lignende projekt for medarbejdere i den kommunale døgnpleje og køkken/service-afdeling. I denne kommune skulle medarbejderne inden for døgnplejen kunne håndtere en såkaldt kommunikationsbog, hvis funktion svarede til den omtalte samarbejdsbog i Greve Kommune. Også til medarbejderne inden for køkken/service-afdelingen blev der stillet krav om skrivning og læsning i arbejdssammenhæng, idet de blandt andet skulle kunne anvende forskelle elektroniske køkkenstyringssystemer.

Formålet med projektet var overordnet at styrke færdighederne i læsning og skrivning, således at medarbejderne fik reelle muligheder for at dokumentere i kommunikationsbogen og/eller orientere sig i omsorgs- og køkkenstyringssystemerne.

\subsubsection{Rekruttering af deltagere}

I alt 100 ansatte i kommunens døgnpleje og køkken/service deltog i en obligatorisk screening, hvor amtets FVU-konsulent anvendte en stavetest

\footnotetext{
${ }^{205}$ NIRAS-konsulenterne (2006). Evaluering af kompetenceudviklingsprojekt „Skriftlig kommunikation“ for medarbejdere i Greve Kommunes Hjemmepleje. Slutevaluering. Roskilde: Roskilde Amt.
} 
fra undervisningsmaterialet „Staveprofilen“. I screeningen deltog både ufaglært og faglært personale foruden medarbejdere med en videregående uddannelse, herunder sygeplejersker. Af de 100 screenede blev der efterfølgende organiseret FVU-kurser for de 60. 8 af de screenede medarbejdere blev af den amtslige FVU-konsulent henvist til andre undervisningstilbud, herunder kompenserende specialundervisning for ordblinde og danskundervisning for indvandrere.

\subsubsection{Deltagernes baggrund og ferdigheder}

I det observerede kursusforløb deltog i alt 12 ansatte. Tre af deltagerne var køkkenassistenter. En af deltagerne arbejdede som sekretær i plejecentrets administration. De øvrige arbejdede som sygehjælpere, social- og sundhedshjælpere eller social- og sundhedsassistenter. Alle var kvinder med dansk som modersmål. Blandt deltagerne på holdet var plejepersonalets tillidsrepræsentant.

Deltagerne havde som nævnt deltaget i en screening. De var alle ud fra den i screeningen anvendte stavetest vurderet til at ligge på omkring trin 2 af de i alt fire FVU-trin. En grundigere afdækning, som blev foretaget cirka midtvejs i forløbet ved hjælp af det af Undervisningsministeriet anbefalede testbatteri ${ }^{206}$, viste imidlertid, at deltagerne spredte sig fra trin 1 til trin 3.

\subsubsection{Undervisningens rammer og indhold}

Det observerede undervisningsforløb var det første af en række FVUkurser, som kommunen afholdt for medarbejdere i døgnplejen og køkken/service-afdelingen. Læreren havde stået for adskillige af de FVUkurser, som tidligere var blevet afholdt for medarbejdere i en anden kommunes hjemmepleje. Læreren havde inden opstarten af kurserne i denne kommune deltaget i et praktikforløb i hjemmeplejen for at få en større forståelse for deltagernes arbejdsfelt, herunder anvendelse af samarbejdsbogen. Disse erfaringer dannede en del af grundlaget for den observerede undervisning.

Undervisningen foregik i et mødelokale på kommunens plejecenter. I lokalet var der tavle, video og seks pc'er til rådighed. Undervisningen varede 56 lektioner og strakte sig over en periode på knap to måneder. Nogle af lektionerne fandt sted fra kl. 8.00 til 14.30, hvorefter deltagerne havde fri. Andre af lektionerne fandt sted fra kl. 11.30 til 15.30, efter at deltagerne havde været på arbejde om formiddagen. Kurset indgik som en del af deltagernes lønnede arbejdstid. Observationen af undervisningen

\footnotetext{
${ }^{206}$ Undervisningsministeriet (2004). Vejledning til trinplacering (2. udgave). Afdækning af FVU-deltageres erfaringer, færdigheder og strategier i læsning, stavning og skriftlig fremstilling. København: Undervisningsministeriet.

(http://us.uvm.dk/voksen/fvu/Vejledninger/documents/Trinplacering-laes-vejl-juni04-vejl.pdf)
} 
fandt sted på to undervisningsgange ved begyndelsen af forløbet og en undervisningsgang ved slutningen af kursusforløbet.

Observationen af undervisningen og interview med læreren viste, at over halvdelen af det anvendte materiale enten var hentet direkte fra deltagernes arbejde eller var af en type, som kunne formodes at have stor lighed med det materiale, som deltagerne typisk mødte i forbindelse med deres arbejde.

Der blev især arbejdet med følgende områder: skriftlig fremstilling, orddannelse og læseforståelse. I det følgende beskrives eksempler på aktiviteter inden for disse områder.

\section{A. Skriftlig fremstilling}

Deltagerne fik udleveret en skriftlig case om en overvægtig plejecenterbeboer med sukkersyge. De arbejdede i grupper med at udforme en såkaldt handle/plejeplan for behandlingen af denne person. De deltagere, der arbejdede i køkkenet, beskæftigede sig især med de ernæringsmæssige aspekter, mens plejepersonalet koncentrerede sig om den personlige pleje. Læreren fremhævede undervejs, at deltagerne ved udformningen af planerne skulle tænke på, at indholdet af dem skal kunne læses af både personale, borgeren selv og pårørende til borgeren. De forskellige planer, der blev udarbejdet, blev efterfølgende uddelt til alle deltagerne, og der blev givet feedback på struktureringen af planerne. En af gruppernes bidrag blev i særlig grad fremhævet som et godt eksempel, mens andre grupper blev opfordret til at uddybe deres bidrag. Læreren uddelte desuden et løsningsforslag, som var udarbejdet af en sygeplejerske, som ikke deltog i kurset.

På grund af en kommende kommunesammenlægning skulle plejepersonalet i kommunen i gang med at bruge en ny elektronisk database, hvor de ansatte blandt andet skulle indsætte en række oplysninger om de borgere, som de havde kontakt med i deres arbejde. I undervisningen øvede nogle af deltagerne sig på at skrive handle/plejeplaner for konkrete borgere ind i den nye database, som der var adgang til fra computerne i undervisningslokalet. Der syntes i starten at herske nogen forvirring om, hvilke oplysninger der skulle stå i de forskellige rubrikker, men da uddannelseslederen på plejecentret blev orienteret om dette problem, blev der næste undervisningsgang udleveret en skriftlig instruktion til deltagerne, som de kunne bruge ved indskrivning af handle/plejeplaner i databasen.

Der blev desuden arbejdet med vurdering og formulering af den sproglige form af den type meddelelser, som plejepersonalet typisk skulle notere i kommunikationsbogen. Deltagerne fik blandt andet udleveret problematiske eksempler på formuleringer som fx „Han påstår, han har ondt hele tiden“; „Såret på skinnebenet var meget snasket og ulcekkert“; „Vi bliver nødt til at tømme kateterposen lidt tiere - familien har brokket sig igen“. Deltagerne fik til opgave at vurdere og omformulere sådanne 
meddelelser i et sprog, der ikke stødte hverken borgerne eller deres pårørende og samtidig var forståeligt for andre medarbejdere i døgnplejen.

\section{B. Orddannelse}

Deltagerne arbejdede med at finde sammensatte navneord i en sundhedsfaglig tekst om urin-inkontinens. De fik endvidere til opgave at danne nye sammensatte navneord på basis af forskellige usammensatte navneord. De blev bedt om at forklare betydningen af de nydannede ord og blev anbefalet at starte med det sidste rodmorfem (fx mundsår = et sår i munden; livstilssygdom = en sygdom, der skyldes personens livsstil).

Deltagerne arbejdede desuden med navnesords bøjningsendelser med udgangspunkt i ord, der hyppigt bruges inden for plejeområdet (fx pause, plejecenter, bcekkenbundstrcening). Efterfølgende fik deltagerne til opgave at finde og rette fejlstavede ord i en jobannonce for social- og sundhedshjælpere (fx borgere stavet som borger).

\section{Lceseforståelse}

De deltagere, som arbejdede i køkkenet, læste en tekst om metoder til beregning af overvægt. Deltagerne skrev et resumé af teksten og fremlagde og kommenterede efterfølgende indholdet for hele holdet.

En sygehjælper, som oplevede at læse for langsomt, arbejdede med forskellige metoder til at differentiere og optræne sin læsehastighed og øvede blandt andet skimmeteknikker på tekster om sundhedsfaglige emner.

\subsubsection{Evaluering}

Kurset blev af læreren evalueret både mundtligt og skriftligt efter hver undervisningsgang. Endvidere blev der afslutningsvis lavet en ekstra grundig skriftlig evaluering, som blev sammenfattet og sendt til observatøren. Sammenfatningen viste, at hovedparten af deltagerne følte, at de havde fået udbytte af undervisningen, ville anbefale kurset til andre og var motiverede for selv at gå gang med et nyt FVU-kursus eller anden danskundervisning på et senere tidspunkt. Nogle af deltagerne gav dog udtryk for, at de gerne ville have været testet grundigere fra starten og i højere grad have arbejdet individuelt med deres egne særlige problemområder. Det kan tilføjes, at det efter gennemførslen af det første FVUkursus for medarbejdere i kommunens døgnpleje og køkken/serviceafdeling som følge af evalueringen blev vedtaget af de projektansvarlige, at deltagere på de kommende kurser skulle testes grundigt en af de første undervisningsgange.

I forbindelse med det nordiske forprojekt blev der kort før slutningen af forløbet gennemført interviews med nogle af deltagerne. En af deltagerne havde en etårig uddannelse som sygehjælper. Hun havde for en del år siden forsøgt at videreuddanne sig til social- og sundhedsassistent, men 
havde opgivet at gennemføre, da hun var dumpet undervejs til en skriftlig eksamen og havde fået at vide, at hendes skriftlige fremstilling var for dårlig. Hun havde som tillidsrepræsentant støttet igangsætningen af FVUkurserne på arbejdspladsen og havde håbet, at hun selv gennem deltagelse i kurset kunne forbedre sine færdigheder så meget, at hun kunne videreuddanne sig. Da hun blev interviewet kort tid før afslutningen af kurset, var hun imidlertid nået frem til den erkendelse, at hun manglede at forbedre sig meget endnu, før hun kunne klare at videreuddanne sig. Hun gav dog udtryk for, at hun havde fået nogle brugbare redskaber, specielt hvad angik læseteknik.

En anden af deltagerne var køkkenassistent. Hun gav udtryk for, at hun kunne bruge meget af det, hun havde lært på kurset, i sin dagligdag. Hun følte, at hun havde forbedret sine færdigheder, især i stavning. Hun udtrykte specielt tilfredshed med, at der på holdet havde været deltagere fra både pleje- og køkkenpersonalet, da hun blandt andet gennem arbejdet med handle/plejeplanerne havde fået en indsigt i plejepersonalets arbejde, som kunne være nyttig i hendes eget arbejde i køkkenet.

En tredje af deltagerne gav udtryk for, at hun ikke følte, at hun havde vanskeligheder med læsning eller stavning. Hun arbejdede som den eneste af deltagerne i administrationen og mente, at hun klarede sit job uden problemer. Efter sin egen opfattelse havde hun ikke brug for kurset, fik ikke noget udbytte af det og ville hellere have brugt sin tid på at deltage i et IT-kursus, hvis hun havde haft valget. Hun mente, at den indledende screening havde givet et skævt billede af hendes færdigheder, og at kurset var overflødigt for hendes eget vedkommende. Dog vurderede hun, at mange af de andre deltagere havde brug for kurset og udbytte af det.

\subsection{Et norsk eksempel: Læse-skriveundervisning i AOF}

I det følgende beskrives et norsk eksempel på læse-, skrive- og staveundervisning. Det valgte eksempel er et læse- og skrivekursus inden for AOF (Arbeidernes Opplysningsforbund) i en by i Østfold amt (norsk: fylke).

Den pågældende AOF-afdeling har holdt kurser for voksne med læseog skrivevanskeligheder siden 1998. Der er kurser på tre forskellige niveauer; alle kurserne er på 102 timer. AOF-afdelingen har i 2000 startet en såkaldt læse- og stavebutik i byens gågade. I denne butik tilbydes der kurser, testning, rådgivning og vejledning for voksne med læse- og skrivevanskeligheder. Tiltaget har fået betydelig opmærksomhed i medierne i Norge, og AOF i flere andre byer har kopieret tiltaget.

Koordinatoren for den norske del af det nordiske forprojekt, Egil Gabrielsen, har i samråd med centralt placerede personer i Kunnskapsdepartementet og læringscentret Vox udvalgt et af denne AOF-afdelings læseog skrivekurser. Egil Gabrielsen har efter aftale med projektledelsen ob- 
serveret en del af undervisningen på et sådant læse- og skrivekursus, interviewet underviseren og nogle af deltagerne samt skrevet rapport om tiltaget. Beskrivelsen af eksemplet bygger på informationer fra denne rapport. ${ }^{207}$

\subsubsection{Begrundelse for valg af undervisningstiltag}

Det konkrete norske læse- og skrivekursus er valgt som norsk eksempel med følgende begrundelse:

1. Det er et af tilbuddene for voksne med svage basisfærdigheder med længst tradition i Norge, og det har samtidig været model for andre AOF-afdelinger i landet.

2. Kursustilbuddet har fået meget opmærksomhed fra medierne og kan derfor være interessant at studere nærmere.

3. Det aktuelle kursustilbud var som udgangspunkt et kursus, som deltagerne selv måtte finansiere. Fra 2005 har kommunen vedtaget, at den selv skal betale kursuspengene for de deltagere, som kommer fra denne kommune. Dette signalerer en anerkendelse af kursustilbuddet fra kommunens side.

4. AOF-afdelingen har fået en central plads i det nyetablerede „Program for basiskompetanse i arbeidslivet“ (BKA-programmet), som er omtalt i rapporten i afsnit 4.3.2.3). Dette indebærer, at indholdet af denne afdelings kurser vil blive spredt til flere andre regioner i Norge inden for det nærmeste år.

\subsubsection{Baggrund for undervisningstiltag}

Norge har ikke igangsat systematiserede tiltag for voksne med svage læse-, skrive- og regnefærdigheder svarende til fx FVU-tilbuddet i Danmark. AOF (Arbeidernes opplysningsforbund), som er en gren af LO (Landsorganisasjonen) i Norge, har presset på for at få igangsat kompetenceopbyggende kurser for kortuddannede i Norge. Den udvalgte AOFafdeling har haft en fremtrædende rolle i denne sammenhæng og kan på mange måder betragtes som dem, som længst har arbejdet med kurser for voksne med svage basisfærdigheder. Der er flere grunde til dette, men to vigtige faktorer kan fremhæves:

1. Høgskolen i Østfold har gennemført en specialpædagogisk uddannelse med fokus på læsning og skrivning (leksologi) i flere år. Dette er i Norge den eneste leksologi- uddannelse, som gennemføres andre steder end i Stavanger (hvor uddannelsen af leksologer startede

\footnotetext{
${ }^{207}$ Gabrielsen, E. (2006). Opplysninger fra Norge. Stavanger: Senter for leseforsking. (Upubliceret rapport udarbejdet i forbindelse med nordisk forprojekt om voksne kortuddannedes læsning).
} 
i 1994). Initiativtagerne til læse- og skrivekurserne i den valgte AOFafdeling har gennemført en sådan uddannelse.

2. Byen, hvor det observerede kursus fandt sted, er en gammel industriby. Byen har traditionelt haft et uddannelsesniveau under gennemsnittet for norske kommuner. Mange har for eksempel været ufaglærte arbejdere i celluloseindustrien; en industri som har haft en betydelig nedgang i antallet af beskæftigede de senere år.

\subsubsection{Rekruttering af deltagere}

Tilbuddet er ret godt kendt gennem omtaler i radio og TV. Deltagere til kurset rekrutteres på mange forskellige måder. Nogle af disse måder nævnes i det følgende:

- Arbejdsformidlingen (norsk: arbeidsmarkedsetat) anbefaler ofte kurset.

- „Trygdekontoret“ henviser til kurset.

- Virksomheder tager kontakt til AOF.

- Tillidsrepræsentanter på virksomheder og tidligere kursusdeltagere anbefaler kurset til venner og kolleger med læse- og skrivevanskeligheder.

- Kursuslokalerne ligger i forbindelse med AOF's læse- og stavebutik, som ligger i gadeplan i byens gågade, og nogle kommer derfor direkte fra gaden for at blive orienteret om tilbuddet.

\subsubsection{Deltagernes baggrund og fardigheder}

Otte deltagere begyndte på kurset i januar. Ved slutningen af maj, hvor kurset blev observeret, havde to af deltagerne valgt at holde op; den ene pga. sygdom og den anden pga. nyt arbejde i en anden kommune.

Af de seks personer, som fortsat deltog i kurset på observationstidspunktet, havde de fem ingen uddannelse ud over grundskolen. Den sjette var uddannet sygehjælper (norsk: hjelpepleier) med en tillægsuddannelse og arbejdede på halv tid som psykiatrisk sygehjælper. En anden deltager var arbejdsleder i en beskyttet virksomhed. En tredje havde deltidsarbejde som natchauffør. En fjerde var under omskoling på grund af nedslidning. De to sidste deltagere var „uføretrygdede“ (pensionerede på grund af helbredsmæssige årsager). Alle deltagerne havde norsk som modersmål.

Deltagerne havde inden undervisningens start deltaget $\mathrm{i}$ en individuel samtale på cirka en time, hvor der også blev foretaget en screening af deres færdigheder i afkodning, stavning, læsehastighed, læseforståelse og ordforråd ved hjælp af materialerne „Ordkjedetesten “ og „Rådgiveren“. Ifølge oplysninger fra læreren var der stor spredning i færdighederne blandt deltagerne. 


\subsubsection{Undervisningens rammer og indhold}

Deltagerafgiften på 4.500 norske kr. blev dækket af kommunen, og det var således gratis for deltagerne at følge undervisningen. AOF modtager statstilskud som voksenundervisningsinstitution.

Kurset strakte sig over et semester (17 uger). Undervisningen foregik to gange om ugen. Hver gang varede undervisningen fire lektioner. Kurset indgik som modul nummer to i en kursusrække på tre moduler, hver på 102 timer. Observationen af undervisningen fandt sted over to undervisningsgange hen imod slutningen af kursusforløbet. Undervisningen fandt sted i et kursuslokale i forbindelse med AOF's læse- og stavebutik.

I løbet af den observerede del af kurset arbejdede deltagerne blandt andet med opgaver i at skrive referater. Der indgik opgaver med at finde antonymer til ord som fx hensynsløs og synonymer til ord som PC. I arbejdet med at finde synonymer til udvalgte ord øvede deltagerne sig $\mathrm{i}$ at bruge ordbøger. Deltagerne arbejdede individuelt med pc-baserede træningsprogrammer, fx programmet „Drillpro“. Der blev endvidere anvendt forskellige IT-hjælpemidler. Underviseren introducerede blandt andet programmet „LingDys“, som giver skrivestøtte til dyslektikere og andre læse-skrivesvage, idet programmet blandt andet giver ordforslag og mulighed for at få det skrevne læst højt. Det blev også demonstreret, hvordan man med en skannerpen kan indskanne en tekst som fx en brugsanvisning og få teksten læst op. Deltagerne fik mulighed for at afprøve hjælpemidlerne.

Observationer af undervisningen og interview med læreren viste, at en relativt stor del af tiden gik med at lave øvelser, som var hentet fra arbejdshæfterne „Les og skriv!““. Disse hæfter er udgivet af AOF og udviklet til forbundets kurser for voksne med læse- og skrivevanskeligheder. Som nævnt arbejdede deltagerne også en del af tiden med pc-baserede træningsprogrammer. Kun en lille del af de materialer, som blev anvendt i undervisningen, var direkte hentet fra eller relateret til deltagernes hverdag. Dog skete det ifølge læreren af og til, at nogle af deltagerne selv medbragte udklip fra aviser og lignende.

\subsubsection{Evaluering}

Der var ikke lagt op til en systematisk evaluering af det beskrevne tiltag. På nogle af AOF-afdelingens hold er udviklingen af deltagernes færdigheder blevet afdækket undervejs ved hjælp af nogle af de test, som blev foretaget før undervisningens start. Der foreligger imidlertid kun oplysninger om testresultater fra en enkelt af deltagerne i det aktuelle kursus. Denne deltager var gået frem på den anvendte test af afkodning. Derudover videregav læreren oplysninger om tre tidligere deltagere, som også var gået frem på denne test. Der foreligger ingen samlet opgørelse for resultaterne fra deltagere i tidligere tilsvarende kurser. 
To deltagere blev interviewet individuelt i forbindelse med indsamlingen af data til det nordiske forprojekt. Den ene var arbejdsleder i en beskyttet virksomhed, og den anden arbejdede som psykiatrisk sygehjælper på halv tid og havde i sin fritid mange hverv, blandt andet i lokalpolitisk sammenhæng. De gav begge udtryk for, at de var godt tilfredse med kursets indhold, og at de brugte en del af det, de lærte på kurset både i arbejde og fritid, blandt andet når de skrev referater. Arbejdslederen var i gang med det andet kursusforløb inden for AOF og vurderede selv, at han især var blevet bedre til at læse, idet han nu læste hurtigere og forstod mere end før sin kursusdeltagelse. Sygehjælperen var i gang med det tredje kursusforløb inden for AOF og havde selv betalt undervisningsafgift for de to tidligere kursusforløb. Han vurderede, at han især var blevet bedre til at stave. Begge deltagere gav udtryk for, at de nu brugte læsning og skrivning betydeligt mere i hverdagen end før deres kursusdeltagelse. Arbejdslederen nævnte som eksempler, at han var begyndt at læse vejskilte og hjælpe sin søn i 1. klasse med lektier, og at han skrev flere huskesedler og oftere brugte e-mail end før. Sygehjælperen nævnte, at han oftere end før brugte internet og e-mail, oftere læste avis og var begyndt at læse eventyr for sine børn.

\subsection{Et svensk eksempel: Læse-skriveundervisning for medarbejdere i Volvo}

I det følgende beskrives et svensk eksempel på læse-, skrive- og staveundervisning. Det valgte eksempel er et tilbud for ordblinde medarbejdere på virksomheden Volvo. Koordinatoren for den svenske del af forprojektet, Ingrid Lavås, har udvalgt eksemplet, observeret en del af undervisningen samt interviewet underviseren og to af deltagerne. Den følgende beskrivelse bygger på de oplysninger, der er indsamlet og rapporteret af Ingrid Lavås ${ }^{208}$, hvis ikke andre referencer er anført.

\subsubsection{Begrundelse for valg af undervisningstiltag}

Et af målene for det nordiske forprojekt var at indsamle eksempler på initiativer i private virksomheder. Derfor blev der ledt efter et eksempel på et lovende tiltag, hvor en privat virksomhed organiserede undervisning for ansatte med læse-, stave- og skrivevanskeligheder. Virksomheden Volvos tilbud om læse- og skriveundervisning for medarbejderne blev valgt som konkret eksempel, da dette var en genoptagelse af et storstilet

\footnotetext{
${ }^{208}$ Lavås, I. (2006). Svenska data i förundersökning av kortutbildade med läs- och skrivsvårigheter. Härnösand: Mittuniversitetet. (Upubliceret rapport udarbejdet i forbindelse med nordisk forprojekt om voksne kortuddannedes læsning).
} 
privat initiativ, som tidligere har vakt stor opmærksomhed og fået positiv omtale både i og uden for Sverige. ${ }^{209}$

\subsubsection{Baggrund for undervisningsforløbet}

En af Volvos afdelinger tilbød i perioden 1995-1998 kurser for medarbejdere med læse- og skrivevanskeligheder. Alle 1000 medarbejdere ved denne afdeling blev ved obligatoriske gruppemøder informeret om ordblindhed og læse-skrivevanskeligheder. De medarbejdere, som kunne genkende sig selv i beskrivelsen, blev tilbudt læse- og skriveundervisning i arbejdstiden. I perioden 1995-1998 tog omkring 100 medarbejdere fra denne afdeling imod tilbuddet og fik læse- og skrive undervisning i $1 \frac{112}{2}$ time om ugen, indtil de syntes, at de havde nået deres personlige mål. ${ }^{210}$

Programmet kostede dengang virksomheden Volvo omkring 2 millioner kroner til udgifter til information, undervisning og løn til medarbejderne, som oppebar fuld løn under deltagelse i undervisningen. Ifølge personaledirektøren har de ordblinde deltagere gennemsnitligt forhøjet deres egen produktivitet med fem procent, og personaleledelsen vurderer på denne baggrund, at investeringen er tjent ind på mindre end to år. I 2003 blev projektet genoptaget. Således har de 350 nyansatte og de medarbejdere, som ikke deltog i undervisning i den første projektperiode, nu også fået tilbud om læse-skriveundervisning i arbejdstiden. ${ }^{211}$

Ifølge den lærer, som står for undervisningen på Volvo, er formålet med undervisningen, at deltagerne generelt bliver bedre til at læse, skrive og stave og til at håndtere læse- og skrivekrav i arbejde, uddannelse og privat. $^{212}$

\subsubsection{Rekruttering af deltagere}

På virksomheden er der blevet holdt et obligatorisk informationsmøde for alle ansatte, hvor læreren har fortalt om muligheden for at deltage i læseog skriveundervisning. Efterfølgende tager læreren individuel kontakt til alle de medarbejdere, som deltog i informationsmødet. De, som ikke tidligere har deltaget i dette tilbud, og som selv oplever at have læse- og skrivevanskeligheder, får mulighed for at få individuel læse- og skriveundervisning i arbejdstiden. Der stilles fra virksomhedens side ingen

\footnotetext{
${ }^{209}$ Eriksen, A. H. (1999). Turbo på de ordblinde. Fagbladet, vol. 31, pp. 14-15. (http://forsiden.3f.dk/apps/pbcs.dll/article?AID=/19990929/FAGBLADET/990929064\&SearchID=7 3270854496444\&profile=2140)

${ }^{210}$ Eriksen, A. H. (1999). Turbo på de ordblinde. Fagbladet, vol. 31, pp. 14-15. (http://forsiden.3f.dk/apps/pbcs.dll/article?AID=/19990929/FAGBLADET/990929064\&SearchID=7 3270854496444\&profile=2140)

${ }^{211}$ Malmodin, H. (2002). Volvo satsar på lästräning - 100 tog ny chans att lära sig läsa. Dagens Nyheter (ekonomidelen), 28/9-2002.

${ }^{212}$ Lavås, I. (2006). Svenska data i förundersökning av kortutbildade med läs- och skrivsvårigheter. Härnösand: Mittuniversitetet. (Upubliceret rapport udarbejdet i forbindelse med nordisk forprojekt om voksne kortuddannedes læsning).
} 
betingelser om, at medarbejderne skal kunne dokumentere læse- og skrivevanskeligheder for at kunne modtage tilbuddet.

\subsubsection{Deltagernes baggrund og fardigheder}

To medarbejdere, som modtog individuel læse- og skriveundervisning, blev interviewet og observeret i forbindelse med det nordiske forprojekt. Begge arbejdede i produktionen i en af Volvos afdelinger og skulle i forbindelse med deres arbejde læse blandt andet beskeder, etiketter, arbejdsbeskrivelser, manualer og rapporter samt skrive blandt andet fejlmeddelelser og ordresedler. Begge deltagere oplyste, at de primært oplevede problemer med stavning og ønskede at forbedre deres færdigheder på dette område. De oplevede ikke i så høj grad problemer med læsning. Ifølge underviserens vurdering havde begge deltagerne læse- og stavevanskeligheder af dyslektisk karakter.

Den ene, som herefter benævnes deltager A, havde foruden grundskolen gået to år på ,verkstadslinje“. Han havde gået i hjælpeklasse i grundskolen på grund af læse- og skrivevanskeligheder. Han havde på observationstidspunktet modtaget cirka 40 undervisningslektioner på Volvo.

Den anden, som herefter kaldes deltager $\mathrm{B}$, havde gået tre år på „bygg/husanläggningslinje“ og derefter uddannet sig til vagt (,väktar“). Han havde ikke fået nogen ekstra hjælp i grundskolen, da hans læse- og skriveproblemer først var blevet opdaget i 8. klasse. Han havde på undersøgelsestidspunktet kun fået cirka fire undervisningslektioner på Volvo.

\subsubsection{Undervisningens rammer og indhold}

Generelt foregår læse-skriveundervisningen på Volvo som en del af deltagernes lønnede arbejdstid.

Hvis undervisningen må lægges uden for arbejdsskiftene, modtager deltagerne overarbejdsbetaling.

Inden undervisningens start foretages der en individuel samtale, hvor deltagernes stavefærdigheder testes ved hjælp af den standardiserede stavetest MG Diktamen I. Hvis en deltager selv ønsker det, foretages der også en afdækning af læsefærdighederne, blandt andet ved hjælp af testene MG 50 Ord og DLS 7-9 Läshatighet. Efter en analyse af deltagernes testresultater planlægges indholdet af kurset i samråd med den enkelte deltager. Undervisningen foregår individuelt. Den finder sted én gang om ugen og varer max. 11/2 time pr. gang. Undervisningsperiodens længde varierer, idet den afhænger af deltagerens behov.

Undervisningen finder sted i lærerens arbejdsværelse på virksomhedens personaleafdeling. I arbejdsværelset er der til brug for deltageren en computer med internetopkobling, talesyntese og læse- skrivetræningsprogrammer. 
Ved begyndelsen af undervisningen kontrollerer læreren, om deltageren har kendskab til alfabetet og andre grundliggende ting. I staveundervisningen arbejder deltageren sig efterhånden systematisk igennem alle de lyde, som det kan være svært at stave til på svensk. Her gennemgås alfabetet, vokaler, konsonanter og sprogets enheder. Derefter gås der videre med forskellige staveregler, som bringes i anvendelse i øvelser på computer og på papir. De tekster, der læses, vælges ud fra deltagerens interesser og udgør grundlaget for øvelser i skriftlig fremstilling, fx udformning af debatindlæg vedrørende tekstens indhold. Der anvendes ITbaseret stave- og grammatikkontrol, når deltageren har formuleret sin tekst.

I forbindelse med det nordiske forprojekt blev der observeret undervisning af de to ovenfor nævnte deltagere A og B. I den individuelle undervisning af deltager A blev der blandt andet arbejdet med regler for stavning af udvalgte lyde ( $t j$-lyden og $m$-lyden) gennem mundtlige forklaringer og diktatøvelser på papir efterfulgt af IT-baserede øvelser, hvor deltageren på egen hånd arbejdede videre med de nævnte lyde, mens læreren sad ved siden af. Deltager A arbejdede desuden med forståelse af en aktuel avisartikel og skrev på denne baggrund selv et debatindlæg om emnet for artiklen. I den observerede undervisning af deltager B blev der arbejdet med kendskab til alfabetet og skelnen mellem vokaler og konsonanter. Deltager B arbejdede desuden med sproglig opmærksomhed, deling af ord i stavelser og nedskrivning af disse ord. Der fandt løbende en pædagogisk dialog sted mellem deltagerne og læreren, således at deltagerne fik indsigt i deres problemer og deres læreprocesser.

\subsubsection{Evaluering}

I forbindelse med det nordiske forprojekt blev der gennemført interviews med deltagerne A og B. Begge deltagere oplyste, at de i deres arbejde brugte det, de lærte i undervisningen, og at de afgjort læste og skrev mere i forbindelse med deres arbejde nu end før. A forklarede, at han skrev længere og mere udførlige rapporter nu, og B fortalte, at han følte sig bedre til at stave og kunne klare at skrive mere end før på arbejdet. De følte også begge, at de i deres fritid læste hurtigere og skrev bedre. A fremhævede, at han nu kunne hjælpe sine børn med lektierne, og B, at han læste avisen mere grundigt nu. De to deltagere udtrykte begge stor tilfredshed med undervisningens indhold og tilrettelæggelse.

Læreren fører løbende en dialog med deltagerne om, hvordan de oplever undervisningen og hvad de har lært. Efter nogen tids undervisning lader læreren deltagerne gennemføre den diktat, som blev anvendt ved begyndelsen af undervisning. Deltager A har således gennemført diktaten i hhv. marts 2004 og i august 2005 og viser ud fra disse diktater at dømme tegn på fremgang i stavefærdigheder. Deltager B har kun gået til undervisning i kort tid og er endnu ikke blevet testet igen. Der foreligger 
ingen samlet opgørelse for resultaterne fra deltagere, der tidligere har deltaget i læse- og skriveundervisning på Volvo.

Som tidligere nævnt har virksomhedens ledelse beregnet, at de medarbejdere, som deltog i læse- og skriveundervisning i den første projektperiode (1995-1998) gennemsnitligt forhøjede deres egen produktivitet med fem procent. ${ }^{213}$

\subsection{Diskussion vedrørende eksempler på undervisningstiltag}

\subsubsection{Overordnede forskelle og ligheder mellem de tre tiltag}

Der er indsamlet data fra tre eksempler på undervisningstiltag, et dansk, et norsk og et svensk. Alle tre tiltag rettede sig mod voksne med utilstrækkelige læse-, skrive- og stavefærdigheder og indbefatter arbejde med læsning, skrivning og IT.

De tre eksempler adskiller sig imidlertid fra hinanden på væsentlige punkter. En af forskellene er rekrutteringsmåden. I det danske eksempel var en stor gruppe ansatte således blevet screenet med en stavetest og derefter sendt på kursus i arbejdstiden, hvis de klarede sig under et vist niveau på testen. Det danske tiltag kan siges at bidrage med en mulig løsning på rekrutteringsproblemet, altså at mennesker med læsevanskeligheder undviger tilbud om læsekrævende kurser og uddannelse; problemet er her forsøgt løst ved at gøre deltagelse i undervisningen obligatorisk. Til gengæld var motivationen hos deltagerne i det danske tiltag muligvis ikke så høj som blandt deltagerne i det norske og svenske eksempel, hvor deltagelsen var baseret på frivillighed. På Volvo informeres medarbejderne om tilbuddet, men vælger selv, om de vil tage imod det, mens nogle af de norske deltagere lige frem havde betalt penge for at følge tidligere dele af AOF's læse- og skrivekursus.

En anden af forskellene er graden af kobling mellem undervisning og deltagernes arbejdsliv. I det danske eksempel foregik undervisningen på det plejecenter, som medarbejderne var knyttet til gennem deres arbejde. Undervisningens indhold var direkte knyttet til deltagernes arbejdsliv, og det kan fremhæves, at underviseren gennem et praktikforløb havde brugt tid på at sætte sig ind i mange af deltagernes arbejdsopgaver. I det svenske eksempel foregik undervisningen ligeledes på deltagernes arbejdsplads, men valget af tekster og opgaver tog ikke direkte udgangspunkt i deltagernes arbejdsliv, men snarere i deres fritidsinteresser og emner, der kan antages at have almen samfundsmæssig relevans for voksne. Det norske undervisningstiltag havde ikke deltagernes arbejdsplads som ramme og var heller ikke i særlig høj grad relateret til deltagernes eventuelle

\footnotetext{
${ }^{213}$ Malmodin, H. (2002). Volvo satsar på lästräning - 100 tog ny chans att lära sig läsa. Dagens Nyheter (ekonomidelen), 28/9-2002.
} 
arbejde. Deltagerne i det norske AOF-tilbud havde en meget forskelligartet baggrund og var i nogle tilfælde slet ikke i arbejde.

En tredje iøjnefaldende forskel er antallet af deltagere. I det svenske tiltag fik deltagerne således eneundervisning, mens deltagerne i de to andre tiltag modtog holdundervisning. Således gik der 12 på det danske FVU-hold og 6 på det norske AOF-hold.

\subsubsection{Kommentarer vedrørende det danske tiltag}

Som nævnt var det danske tiltag for ansatte inden for en kommunal døgnpleje og køkken-service-afdeling karakteriseret ved, at der var en direkte sammenhæng mellem deltagernes arbejde og undervisningens tilrettelæggelse. Der er især i USA gennemført forskning, som det kan være relevant at inddrage i en vurdering af det beskrevne danske undervisningstiltag. De amerikanske forskere Mikulecky \& Lloyd har således vurderet kvaliteten af en række forskellige arbejdsrelaterede tilbud om læse- og skriveundervisning. ${ }^{214}$ Disse forskere har fundet, at deltagere især forbedrer deres læse- og skrivefærdigheder og bliver i stand til at overføre de indlærte færdigheder til arbejdsrelaterede aktiviteter, hvis følgende betingelser i undervisningen er opfyldt:

- at deltagerne beskæftiger sig med læsning og skrivning i mindst $70 \%$ af undervisningstiden

- at deltagerne i undervisningen arbejder med materialer, som de har brug for at læse og skrive på arbejdspladsen (mindst 20-30 \% af de anvendte materialer skal være arbejdsrelaterede og indbyggede i kursets struktur)

- at der løbende foregår en diskussion med deltagerne om deres mål med og udbytte af undervisningen.

Det danske observerede tiltag kan siges at opfylde disse betingelser; deltagerne var således faktisk i hovedparten af den observerede undervisningstid beskæftigede med læse- og skriveaktiviteter, der var relateret til deres arbejdsområde, og der foregik en løbende evaluering af undervisningens indhold. Det er imidlertid ikke undersøgt, om deltagerne faktisk forbedrede deres læse-, skrive- og stavefærdigheder i løbet af undervisningen.

Det danske forløb blev afholdt inden for rammerne af FVU-systemet, som er beskrevet nærmere i afsnit 4.4.4.1.1. Ser man på det danske tiltag som et eksempel på et FVU-forløb, kan det fremhæves, at der i den observerede undervisning indgik hovedparten af de elementer, der ifølge FVU-undervisningsvejledningen skal undervises i, herunder orddannelse, ordkendskab, læseforståelse, skriftlig fremstilling og brug af skrevne

\footnotetext{
${ }^{214}$ Mikulecky, L. \& Lloyd, P. (1996). Evaluation of Workplace Literacy Programs: a Profile of Effective Instructional Practices. Journal of Literacy Research, 29(4), 555-585.
} 
tekster i hverdagen. ${ }^{215}$ Undervisningen kan således karakteriseres som et „regulært“ FVU-forløb, hvor de forskellige elementer blot var tilpasset den særlige kontekst, som udgjordes af deltagernes arbejdsliv. På et enkelt punkt afveg forløbet dog fra de foreskrivelser, som Undervisningsministeriet har givet. Ministeriet anbefaler således, at der inden et FVUforløbs begyndelse foretages en afdækning af deltagernes færdigheder inden for læsning, stavning og skriftlig fremstilling som grundlag for trinplacering og planlægning af undervisning. ${ }^{216}$ Denne anbefaling kan ikke siges at være fulgt i det observerede danske tiltag, idet deltagerne kun havde deltaget i en overfladisk screening i forhold til stavefærdigheder inden undervisningens start og først blev testet grundigere langt henne i forløbet. Flere af deltagerne gav ved afslutningen af forløbet udtryk for, at de gerne ville have været testet grundigere fra starten og i højere grad have arbejdet individuelt med deres egne særlige problemområder. Som tidligere nævnt blev det efterfølgende vedtaget af de projektansvarlige, at deltagere på de kommende kurser skulle testes grundigt en af de første undervisningsgange. Indirekte tyder dette forløb på, at Undervisningsministeriets anbefaling vedrørende en indledende afdækning af deltagernes færdigheder inden for både læsning, stavning og skriftlig fremstilling er yderst relevant.

\subsubsection{Kommentarer vedrørende det norske tiltag}

I det norske observerede eksempel udgjordes målgruppen ikke som i det danske og det svenske eksempel af personer fra en bestemt arbejdsplads. Deltagerne havde en mere forskelligartet baggrund og blev rekrutteret på forskellig vis. Det kan fremhæves som noget særligt ved tiltaget, at undervisningen foregik i lokaler med tilknytning til AOF’s læse- og stavebutik, der som nævnt ligger i gadeplan i byens gågade. Dette giver formodentlig nogle særlige muligheder for at vække opmærksomhed og rekruttere personer, som måske ikke ellers ville melde sig til et læseskrivekursus.

På nogle af AOF-afdelingens hold er udviklingen af deltagernes færdigheder som nævnt blevet afdækket undervejs ved hjælp af nogle af de test, som blev foretaget før undervisningens start. Der foreligger imidlertid ingen samlet opgørelse for resultaterne fra deltagere i det igangværende forløb eller fra tidligere kurser. Det er derfor uklart, i hvilket omfang deltagere i denne type undervisningsforløb faktisk har forbedret deres færdigheder som følge af undervisningen.

\footnotetext{
${ }^{215}$ Undervisningsministeriet (2002). Undervisningsvejledning. Forberedende voksenundervisning (FVU) i læsning, stavning og skriftlig fremstilling. København: Undervisningsministeriet. (http://us.uvm.dk/voksen/fvu/undervisningsvejl laesning.pdf)

${ }^{216}$ Undervisningsministeriet (2004). Vejledning til trinplacering (2. udgave). Afdækning af FVU-deltageres erfaringer, færdigheder og strategier i læsning, stavning og skriftlig fremstilling. København: Undervisningsministeriet. (http://us.uvm.dk/voksen/fvu/Vejledninger/documents/Trinplacering-laes-vejl-juni04-vejl.pdf)
} 
De to interviewede deltagere forekom at være meget tilfredse med undervisningen og gav udtryk for, at de fik udbytte af den, hvilket naturligvis kan siges at være positivt. Men som det tidligere er fremgået af kapitel 4, er det helt almindeligt, at deltagere i frivillig undervisning udtrykker, at de føler, at de har fået udbytte af undervisningen - uden at dette nødvendigvis hænger sammen med deres faktiske udbytte, som det kan måles ved hjælp af læse- og stavetest (jf. den danske undersøgelse af effekten af deltagelse i kompenserende specialundervisning ${ }^{217}$ omtalt i afsnit 4.2.2.2.2 - A). Den amerikanske forsker Diekhoff (1988) advarer da også på baggrund af en analyse af effekten af en række læse- og skrivekurser mod at basere evalueringer af sådanne kurser primært på deltagernes egne vurderinger, da disse kan være overdrevent optimistiske. ${ }^{218}$

\subsubsection{Kommentarer vedrørende det svenske tiltag}

Et særkende ved undervisningen på Volvo er, at den er individuel. Dette giver oplagt særlige muligheder for at skræddersy undervisningen specielt til de enkelte deltagere.

Endvidere forekommer det svenske tiltag at være det af de tre beskrevne tiltag, hvor der mest konsekvent foretages en form for afdækning af udviklingen i deltagernes færdigheder. Ifølge de indsamlede oplysninger bliver deltagernes færdigheder i stavning således ved hjælp af en stavetest undersøgt før undervisningsforløbets start, og når deltagerne har modtaget undervisning et stykke tid, gennemgår de den samme stavetest. På denne baggrund har læreren mulighed for at vurdere, om den enkelte deltager er gået frem, hvad angår stavefærdighed.

Imidlertid er der ikke tale om nogen særlig omfattende afdækning, idet deltagernes udvikling i færdigheder i fx læsning og skriftlig fremstilling ikke testes. Der foreligger heller ikke nogen samlet opgørelse for udviklingen i stavefærdighederne for større grupper, der har deltaget i læse- og skriveundervisning på Volvo. Derfor er det vanskeligt for udenforstående at vurdere, i hvor høj grad medarbejderne faktisk forbedrer deres læse-, skrive- og stavefærdigheder som følge af deltagelse i undervisningstilbuddet.

\subsubsection{Afrunding vedrørende de tre tiltag}

I alle de rapporterede tiltag indgår der elementer, der sandsynligvis vil kunne inspirere andre udbydere og undervisere. Imidlertid er det vanskeligt at vide med sikkerhed, om de beskrevne tiltag faktisk er bedre end så mange andre tiltag og således værd at kopiere. Dette skyldes blandt andet,

\footnotetext{
${ }^{217}$ Holders, B., Petersen, D.K., Borstrøm, I. \& Elbro, C. (1996). Undervisning af voksne ordblinde. En undersøgelse af undervisningseffekt og lærerkvalifikationer i ordblindeundervisningen i AOF. Forlaget Skolepsykologi.

${ }^{218}$ Diekhoff, G. M. (1988). An appraisal of adult literacy programs. Journal of Reading, vol. 31(7), 624-630.
} 
at der ikke ud fra beskrivelserne er noget pålideligt grundlag for at vurdere, om de anvendte metoder gavner voksne deltagere mere end andre metoder.

Det er i det hele taget et problem med eksempler på „best practice“, at det er uklart, hvad det er ved en given praksis, der er „bedst“ og værd at kopiere. Er det fx de anvendte undervisningsmetoder, rekrutteringsmåden eller lærerens engagement? Hvis man vil vide, om anvendelse af bestemte metoder inden for læse- og skriveundervisning fører til bedre resultater end andre metoder, er gennemførelse af egentlige effektundersøgelser den mest sikre vej til at opnå denne viden (jf. den foregående diskussion i afsnit 4.8). 


\section{Afdækning af krav til og færdigheder i læsning og skrivning i uddannelses- og arbejdssammenhæng}

\subsection{Sammenfatning}

Som kapitel 6 viser, er det en kompliceret sag at afdække læse- og skrivekrav i en given uddannelses- eller arbejdssammenhæng. Dette hænger sammen med, at sådanne krav afhænger af mange forskellige faktorer. Om der er høje eller lave krav, er således blandt andet betinget af, hvor meget og hvad der skal læses og skrives, samt af, hvor vigtig en rolle læsning og skrivning spiller for gennemførslen af en uddannelse eller udførslen af et arbejde. Det kan endvidere være vanskeligt at afgøre, om en person har de færdigheder og forudsætninger, der er nødvendige for at opfylde læse- og skrivekravene i en bestemt uddannelses- eller arbejdssammenhæng. Også her spiller mange forskellige faktorer ind. Foruden de specifikke færdigheder inden for læsning eller skrivning, som en person kan have udviklet netop inden for sin aktuelle uddannelse eller arbejdsfunktion, kan hans generelle niveau af læse- og skrivefærdigheder således spille en væsentlig rolle. Endvidere kan en persons kendskab til fagområdet eller branchen være af afgørende betydning for hans mulighed for at udføre de læse- og skriverelaterede opgaver, der indgår som en del af arbejdet eller uddannelsen.

I uddannelsessammenhœeng er der i tidligere undersøgelser med henblik på afdækning af kravene til læsning og skrivning blandt andet gennemført observationer af undervisningssituationer, indsamlinger og analyser af de materialer, som indgik i undervisningen, samt interviews med underviserne og deltagerne. Disse undersøgelser tyder på, at der i praktisk orienterede uddannelser er store forskelle med hensyn til, hvor meget og hvad der skal læses og skrives. I nogle uddannelser er de anvendte materialer relativt svært tilgængelige, men dette kompenseres der i nogle tilfælde for, fx gennem mundtlige gennemgange af stoffet, således at læsning ikke nødvendigvis spiller en afgørende rolle for deltagernes tilegnelse af faglig viden (jf. afsnit 6.3.1.1).

Til afdækning af uddannelsesdeltageres generelle læse- og skrivefærdigheder er der i tidligere undersøgelser typisk benyttet almene testmaterialer, hvis indhold og udformning ikke er relateret til et bestemt fagområde. Derudover er der i forbindelse med flere undersøgelser udviklet 
fagspecifikke test til afdækning af deltageres færdigheder i og forudsætninger for at læse nogle af de tekster, der blev anvendt i de undersøgte uddannelser. Sådanne undersøgelser har vist, at unge og voksnes forståelse af uddannelsestekster i høj grad er relateret til såvel deres generelle niveau af læsefærdigheder som til deres kendskab til uddannelsens fagområde (jf. afsnit 6.3.2.1 og 6.3.2.2).

I nogle undersøgelser er der endvidere anvendt spørgeskemaer til afdækning af deltagernes egne vurderinger af såvel uddannelsesteksternes sværhedsgrad som af betydningen af læse-stavefærdigheder for uddannelsen. Disse undersøgelser tyder på, at der er en sammenhæng mellem deltagernes objektivt målbare læsefærdigheder og deres selvvurderede vanskeligheder i forbindelse med læsning og skrivning i uddannelsessammenhæng (6.3.2.3 og 6.3.2.4)

I arbejdssammenhceng er læse- og skrivekravene blandt andet undersøgt gennem observationer af arbejdssituationer, medarbejderes egne notater vedrørende omfanget og karakteren af deres læsning og skrivning samt interviews med ledere og medarbejdere. Endvidere er der foretaget indsamlinger og analyser af de materialer, som blev anvendt på de undersøgte arbejdspladser. Sådanne undersøgelser viser, at voksne med praktisk betonet arbejde ofte kun læser kort tid ad gangen i forbindelse med udførelsen af arbejdsfunktionerne. Tekster bruges typisk til at slå enkelte oplysninger op i, mens skrivning ofte foregår i korte sætninger, enkelte ord og koder (jf. afsnit 6.4.1.2). Derudover kan der indgå mere omfattende læsning og skrivning i forbindelse med fx mødedeltagelse, planlægning af arbejdsprocesser, kvalitetskontrol og dokumentation af det udførte arbejde. Betydningen af læsning og skrivning varierer betydeligt mellem forskellige jobs, men specielt krav om skriftlig dokumentation synes at spille en stadig større rolle, også i en række jobs, der ikke forudsætter noget højt uddannelsesniveau (jf. afsnit 6.4.1.5, 6.4.1.6 og 6.4.1.7)

Til afdækning af medarbejderes generelle læse- og skrivefærdigheder færdigheder er der benyttet almene testmaterialer. Til afdækning af jobrelaterede læse- og skrivefærdigheder er der i flere projekter uden for Norden udviklet skræddersyede test, der specifikt er relaterede til arbejdsmaterialer og -situationer (jf. fx 6.4.2.1 og 6.4.2.2).

På basis af resultaterne fra relevante undersøgelser afsluttes kapitlet med en diskussion af forhold, der har relevans for spørgsmålet om, hvordan der kan foretages afdækning af krav til og færdigheder i læsning og skrivning i uddannelses- og arbejdssammenhæng (jf. afsnit 6.5).

\subsection{Krav til og færdigheder i læsning og skrivning}

I det følgende gives der en kort gennemgang af nogle af de aspekter, som det er relevant at tage i betragtning, når der skal foretages en vurdering af læse- og skrivekrav i en given uddannelses- og arbejdssammenhæng samt 
af de enkelte deltageres eller medarbejderes forudsætninger for at opfylde disse krav. Denne gennemgang skal tjene som baggrund for den efterfølgende oversigt over tidligere undersøgelser i afsnittene 6.3 og 6.4 samt for forslagene til kommende projekter i kapitel 7.

\subsubsection{Læse- og skrivekrav i arbejde og uddannelse}

Ved en vurdering af læse- og skrivekrav kan det være relevant at belyse mange forskellige faktorer. Om der er høje eller lave krav, afhænger således blandt andet af omfanget, betydningen og karakteren af læse- og skriveopgaverne i en given uddannelses- eller jobsammenhæng. Disse faktorer konkretiseres i punkterne $\mathrm{A}-\mathrm{C}$ nedenfor.

\section{A. Omfang og hyppighed}

Der er i forskellige jobs og uddannelser forskellige forventninger til, hvor meget og hvor ofte der skal læses og skrives. I uddannelsessammenhæng kan blandt andet et stort tekstpensum og aflevering af mange og omfangsrige skriftlige opgaver indikere høje læse- og skrivekrav. I arbejdssammenhæng findes der sjældent på samme måde som i uddannelsessammenhæng formelle beskrivelser af, hvor meget der skal læses og skrives, men det er ud fra en intuitiv betragtning oplagt, at nogle jobs (som fx sekretær) indebærer væsentligt mere og hyppigere læsning og skrivning end andre jobs (som fx pædagogmedhjælper).

\section{B. Betydning}

Der kan være store forskelle med hensyn til, hvor vigtig læsning er som kilde til tilegnelse af den viden, som er nødvendig for at gennemføre en uddannelse eller varetage et job. På nogle uddannelser er læsning den primære kilde til tilegnelse af faglig viden, mens deltagerne på andre uddannelser kan tilegne sig en stor del af stoffet på andre måder end gennem læsning af det formelle pensum, $\mathrm{fx}$ via mundtlig gennemgang af stoffet. Tilsvarende kan den nødvendige viden for udførelse af en arbejdsfunktion på nogle arbejdspladser tilegnes gennem sidemandsoplæring eller andre måder, hvor læsning af eventuelle skriftlige instruktioner ikke spiller en afgørende rolle. Endvidere kan der både i uddannelses- og jobsammenhæng være store forskelle med hensyn til betydningen af, at en person kan dokumentere og videregive sin viden til andre i skriftlig form.

\section{Karakter}

Karakteren af læse- og skriveopgaver varierer inden for forskellige uddannelser og erhverv. Der vil således være forskelle med hensyn til, hvilke typer af tekster, der skal læses, hvad de skal bruges til, og hvor svære de pågældende tekster er. I mange tilfælde er brugen af en tekst tæt relateret til typen af den pågældende tekst. Fx lægger en instruktion typisk op til, at den skal læses omhyggeligt, således at den kan følges nøje. Andre teksttyper, fx tabeller, skal derimod sjældent læses i deres helhed, men 
snarere bruges til at lokalisere enkelte specifikke oplysninger. Tilsvarende vil der mellem uddannelser og jobs være forskelle med hensyn til, hvilke teksttyper deltagerne eller medarbejderne skal skrive, og hvilken form for skrivning der kræves. Fx lægger udarbejdelse af opgaver, rapporter og logbøger op til megen og selvstændig skriftlig formulering, hvorimod skemaer ofte kun skal afkrydses eller udfyldes med ganske få ord.

De konkrete tekster, der skal læses i en uddannelse eller et arbejde, kan endvidere variere med hensyn til tilgcengelighed. Tekster kan således være svært tilgængelige rent visuelt og næsten ulæselige, hvis de fx er af en ringe trykkekvalitet eller har et rodet layout. Tekster kan også være sprogligt svært tilgængelige og vanskelige at forstå, fx på grund af en høj koncentration af sjældne ord, lange sætninger og indviklede sætningskonstruktioner. Hvis mange af de anvendte tekster i en given uddannelseseller arbejdssammenhæng er svært tilgængelige, vil det alt andet lige medvirke til at gøre læsning til en vanskelig opgave for deltagerne eller medarbejderne.

\subsubsection{Færdigheder i og forudsætninger for læesning og skrivning i arbejde og uddannelse}

Ved en vurdering af personers færdigheder i og forudsætninger for at læse og skrive uddannelses- eller arbejdsrelateret materiale kan det være relevant at tage mange forskellige faktorer i betragtning. Nogle af de vigtigste beskrives kort under punkt $\mathrm{A}-\mathrm{C}$ i det følgende.

\section{A. Specifikke læese- og skrivefcerdigheder}

En person kan være i besiddelse af nogle specifikke færdigheder inden for læsning eller skrivning, som kan være udviklet netop inden for den uddannelse, han er i gang med eller det arbejde, som han er ansat til.

\section{B. Generelle liese- og skriveferdigheder}

En persons generelle niveau af læse- og skrivefærdigheder kan spille en væsentlig rolle for hans udførelse af læse- og skriverelaterede opgaver, der indgår som led i hans uddannelse eller arbejde. Det kan således forventes, at en person, der generelt læser langsomt og usikkert og har vanskeligheder med at stave og formulere sig skriftligt, også vil have svært ved at læse mange arbejds- eller uddannelsesrelaterede tekster og udføre opgaver, der indebærer skriftlig fremstilling.

\section{Fagspecifik viden}

I forbindelse med læsning og skrivning i uddannelses- eller arbejdssammenhæng udgør kendskab til fagområdet eller branchen et centralt aspekt. Alt andet lige vil et omfattende forhåndskendskab til det emne, som en konkret tekst handler om, gøre det lettere at læse den pågældende tekst, 
idet et sådant forhåndskendskab typisk vil indebære kendskab til centrale faglige ord og begreber og danne grundlag for forståelsen af tekstens oplysninger. Tilsvarende vil omfattende indsigt og/eller erfaring med et fagområde og dets terminologi gøre det lettere for en person at formulere sig skriftligt på en adækvat måde.

\subsection{Tidligere undersøgelser i uddannelsessammenhæng}

I det følgende gives der en oversigt over relevante uddannelsesrelaterede undersøgelser, idet der fokuseres på praktisk orienterede uddannelser. Oversigten falder i to dele, således at der først gennemgås undersøgelser af læse- og skrivekrav og dernæst af deltageres færdigheder i og forudsætninger for læsning og skrivning i uddannelsessammenhæng. Der indgår nordiske såvel som ikke-nordiske undersøgelser i oversigten.

\subsubsection{Tidligere undersøgelser af lcese- og skrivekrav i} uddannelsessammenhreng

6.3.1.1 Dansk undersøgelse af omfang, karakter og betydning af læsning og skrivning i erhvervs- og arbejdsmarkedsuddannelser

Som omtalt i afsnit 3.2.4.1 har Lund, Bertelsen \& Sørensen (2006) på baggrund af blandt andet observationer af undervisning og eksaminer samt interviews og analyser af anvendte skriftlige materialer gennemført en undersøgelse af kravene til skriftsproglige færdigheder i udvalgte erhvervsuddannelser (EUD) og arbejdsmarkedsuddannelser (AMU). ${ }^{219}$ Analyserne inddrog en række forskellige typer af materialer, som blev benyttet i den observerede undervisning, herunder grundbøger, tekstkompendier, instruktionsark, opgaveark og elektronisk materiale såsom cdrom. Desuden blev der foretaget analyser af eksempler på skriftlige opgaver udarbejdet af elever på holdene eller af tidligere elever i den samme type undervisning.

Analyserne viste blandt andet, at de anvendte undervisningsmaterialer krævede, at eleverne beherskede en række forskellige læsestrategier, herunder nærlæsning for at læse og forstå skriftlige instruktioner til opgaver samt skimme- og skannelæsning for kunne overskue og finde relevante oplysninger på skilte og forskrifter ophængt i læringsrummet.

Forfatterne vurderede endvidere de anvendte materialers sproglige tilgængelighed og konkluderede, at materialerne på både EUD og AMU indeholdt ikke blot en stor mængde fagudtryk, men også meget såkaldt „førfagligt gråzonesprog“. Herved forstås ord og udtryk som fx linjer, økonomi og indtastning, der er bekendte af modersmålsbrugere, men som ofte

\footnotetext{
${ }^{219}$ Lund, K., Bertelsen, E. \& Sørensen, M.S. (2006). Muligheder og barrierer - en undersøgelse af overgangen mellem sprogcentre og erhvervsrettede uddannelser. København: Ministeriet for Flygtninge, Indvandrere og Integration.
} 
er ukendte for elever og kursister med dansk som andetsprog og som derfor medvirker til at gøre tekster vanskeligt tilgængelige for denne gruppe. Undersøgelsen viste dog også, at der især i AMU blev kompenseret en del for det tunge læsestof, blandt andet gennem mundtlig gennemgang af stoffet. Således syntes betydningen af læsning som kilde til faglig viden at være mindre på AMU end på EUD.

Med hensyn til skrivning viste undersøgelsen, at der på nogle erhvervsuddannelser (EUD) indgik rapportskrivning og skriftlige opgaver i flere fag foruden logbogsskrivning samt krav til eleverne om refleksioner over deres egne skriftlige arbejder. På arbejdsmarkedsuddannelser (AMU) indgik skrivning kun i mindre grad, primært i forbindelse med besvarelse af kontrolspørgsmål og udfyldning af skemaer. Skrivekravene forekom således i lighed med læsekravene større på EUD end på AMU.

\subsubsection{Amerikansk undersøgelse af omfang og karakter af læsning i} erhvervsuddannelser

I USA har Rush, Moe \& Storlie (1986) undersøgt læse- og skrivekrav i ti praktisk betonede erhverv, som fx elektriker, mekaniker og maskinarbejder, samt de tilhørende uddannelser. ${ }^{220}$ Rush og hans kolleger indsamlede og analyserede materialer, der blev anvendt i de udvalgte erhverv og uddannelser. Desuden blev brugen af materialerne undersøgt gennem observationer samt interviews med deltagere i de udvalgte uddannelser og ansatte og ledere fra de udvalgte erhverv.

Forskergruppen fandt, at der i de forskellige uddannelser blev brugt væsentligt mere tid på læsning end i de tilhørende erhverv. Det gennemsnitlige tidsforbrug varierede stærkt mellem de enkelte uddannelser og spændte fra 42 minutter til seks timer dagligt. Eleverne læste især lærebøger, håndbøger og instruktioner. Rush et al. foretog analyser af de anvendte materialer og fandt, at den sproglige sværhedsgrad spændte fra 8. klasse til college-niveau. Endvidere fandt Rush et al., at læsning i uddannelsessammenhæng primært sigtede mod indlæring og refleksiv mental bearbejdning af den læste information, så denne information kunne genkaldes og bruges længe efter læsningen. I modsætning hertil foregik læsning i arbejdssammenhæng primært med henblik på at følge skrevne instruktioner og finde information til øjeblikkeligt brug.

6.3.1.3 Dansk undersøgelse af fagtekster i en arbejdsmarkedsuddannelse Møller \& Nielsen (1986) gennemførte på en arbejdsmarkedsuddannelse inden for rengøringsområdet en undersøgelse af de anvendte fagtekster. ${ }^{221}$ En test viste, at kursisternes forståelse af de udvalgte uddannelsestekster var meget ringe. Men dette skyldtes ikke, at kursisterne ge-

\footnotetext{
${ }^{220}$ Rush, R.T., Moe, A.J. \& Storlie, R.L. (1986). Occupational Literacy Education. Newark, DE: International Reading Association.

${ }^{221}$ Møller, S. \& Nielsen, R. (1986). Svage læsere eller dårlige tekster? En undersøgelse af tekster og læsere på kurser for specialarbejdere. Pædagogiske forskningsrapporter nr. 35. København: Læsepædagogen.
} 
nerelt var ringe læsere; en supplerende test viste nemlig, at de fungerede som middelgode læsere på en middelsvær skønlitterær tekst. Nærmere analyser viste, at de anvendte uddannelsestekster var skrevet i et meget svært tilgængeligt og knudret fagsprog, som gjorde dem vanskelige at forstå. Eksempelvis indeholdt en af de anvendte tekster med overskriften „Tæeppekonstruktioner“ følgende passage: „Ved luvvævede stoffer forstås en vare, der består af en tætvævet grundflade, i hvilken luven er fastbundet enten i form af en uopskåret luv (nopper)-uopskåret mekka eller epinglé - eller en opskåret luv-plys eller velour.“

\subsubsection{Tidligere undersøgelser af deltageres ferdigheder i og forudscetninger for lcesning og skrivning i uddannelsessammenhæeng}

6.3.2.1 Dansk undersøgelse af PGU-elevers færdigheder i og forudsætninger for faglig læsning

I Danmark har Gellert (1999) gennemført en undersøgelse af faglig læsning blandt 40 deltagere på den pædagogiske grunduddannelse (PGU). ${ }^{222}$ Undersøgelsen viste, at deltagernes forståelse af uddannelsestekster i høj grad var relateret til såvel deres generelle niveau af lcesefcerdigheder som til deres fagspecifikke ordkendskab. En meget stor del af spredningen i deltagernes resultater på en test af forståelse af uddannelsestekster kunne således „forklares“ på grundlag af deres resultater på en test af forståelse af hverdagstekster. Men selv når der var taget højde for forskellene i elevernes færdigheder i at læse hverdagstekster, var der stadig en væsentlig del af den tilbageblevne variation i forståelsen af faglige uddannelsestekster, der kunne „forklares“ af fagligt ordkendskab.

6.3.2.2 Dansk undersøgelse af AMU-deltageres færdigheder i og forudsætninger for faglig læsning

I en dansk undersøgelse af 251 AMU-deltagere fandt Arnbak (1999) i lighed med den ovennævnte undersøgelse af PGU-elever, at der var en stærk sammenhæng mellem deltagernes forståelse af hhv. faglige uddannelsestekster og hverdagstekster. ${ }^{223}$ Endvidere bidrog deltagernes erhvervserfaring inden for uddannelsens faglige område med selvstændig „forklaringsværdi“ i forhold til, hvor godt de forstod fagtekster, også efter at der var taget højde for spredningen i deltagernes færdigheder i læsning af hverdagstekster.

\footnotetext{
${ }^{222}$ Gellert, A. (1999). Hvordan kan man forudsige forskelle i elevers læseforståelse af faglige uddannelsestekster? En undersøgelse af en elevgruppe på den pædagogiske grunduddannelse. Psykologisk Pcedagogisk Rådgivning, 36(5-6), 395-418.

${ }^{223}$ Arnbak, E. (1999). Faglig læsning i AMU - en undersøgelse af sammenhængen mellem AMU-deltageres funktionelle læsefærdighed og deres faglige læsning. København: Arbejdsmarkedsstyrelsen.
} 
6.3.2.3 Dansk undersøgelse af læse- og stavefærdigheder og deres betydning for uddannelse

Dansk Videnscenter for Ordblindhed (2006) gennemførte i forbindelse med en afprøvning af et nyt materiale en afdækning af færdigheder i afkodning, stavning og ordkendskab blandt deltagere fra ordblindeundervisning, forberedende voksenundervisning (FVU), almen voksenuddannelse (AVU) og teknisk skole. ${ }^{224}$ I forbindelse hermed blev der ved hjælp af et spørgeskema foretaget en afdækning af deltagernes selvvurdering på en række områder. Deltagerne blev således blandt andet spurgt, om deres læse- og stavevanskeligheder havde haft betydning for deres uddannelse. Undersøgelsen viste, at de deltagere, som var i gang med en uddannelse og som følte sig generet af læse- og stavevanskeligheder, havde markant ringere afkodningsfærdigheder end dem, der ikke følte sig generet. Dog var der ikke nogen fast grænse for, hvornår personerne følte sig generet af læse-stavevanskeligheder. Specielt de deltagere, som var i gang med en lang videregående uddannelse, oplevede, at de blev generet af læse- og stavevanskeligheder, selv om deres færdigheder objektivt målt ikke var påfaldende ringe sammenlignet med andre deltagergruppers færdigheder. Fx var stavefærdighederne på samme niveau blandt studerende i videregående uddannelse, der følte sig generet af læse- og stavevanskeligheder, som blandt teknisk-skole-elever, der ikke var generede.

6.3.2.4 Dansk undersøgelse af deltageres læsefærdigheder og oplevelse af fagteksters sværhedsgrad

Som beskrevet i afsnit 3.4.3.2 gennemførte Arnbak \& Elbro (1999) en undersøgelse af færdighederne i afkodning og læseforståelse blandt unge og voksne fra forskellige kurser og uddannelser. ${ }^{225}$ Undersøgelsen viste blandt andet, at der blandt 167 undersøgte unge i tekniske erhvervsuddannelser var relativt stærke sammenhænge mellem deltagernes præstationer på læsetestene og deres vurdering af, hvor svært det var at læse teksterne til de forskellige fag i den uddannelse, de var i gang med.

\subsection{Tidligere undersøgelser i arbejdssammenhæng}

I det følgende gives der en gennemgang af relevante undersøgelser i arbejdssammenhreng. I lighed med oversigten over uddannelsesrelaterede undersøgelser i afsnit 6.3 falder den følgende gennemgang i to dele, således at der først gennemgås undersøgelser af læse- og skrivekrav og der-

\footnotetext{
${ }^{224}$ Dansk Videnscenter for Ordblindhed (2006). Rapport om afprøvning af visitationstest til brug i ordblindeundervisning for voksne. København: Undervisningsministeriet. (http://us.uvm.dk/voksen/fvu/documents/endelig_rapport.doc)

${ }^{225}$ Arnbak, E. \& Elbro, C. (1999). Læsning, læsekurser og uddannelse. Om unge og voksnes funktionelle læsefærdighed i uddannelse og på læsekurser vurderet med et nyt materiale. København: Center for Læseforskning, Københavns Universitet.
} 
næst af medarbejderes færdigheder i og forudsætninger for læsning og skrivning. Der indgår nordiske såvel som ikke-nordiske undersøgelser.

\subsubsection{Tidligere undersøgelser af læese- og skrivekrav i arbejds- sammenhæeng}

6.4.1.1 Dansk undersøgelse af hyppighed og karakter af læsning og skrivning i forskellige brancher

Som nævnt i afsnit 3.2.3.3 gennemførte Munch-Hansen \& Albæk (1994) en undersøgelse blandt AMU-kursister, der arbejdede inden for hhv. elektronik, metal, jordbrug og landtransport. ${ }^{226}$ Der blev blandt andet gennemført en spørgeskemaundersøgelse af, hvor hyppigt kursisterne læste og skrev forskellige typer af tekster i deres arbejde. Denne undersøgelse viste, at over $70 \%$ af kursisterne jævnligt eller af og til i deres arbejde havde skullet læse blandt andet opslag på opslagstavle, etiketter på beholdere, betjeningsvejledninger og sikkerhedsregler og havde skullet udfylde arbejdssedler og skrive beskeder. Langt hovedparten oplevede således, at læsning og skrivning indgik som en del af deres arbejde.

Ved siden af spørgeskemaundersøgelsen blev der gennemført virksomhedsbesøg, hvor det gennem interviews blev belyst, hvilke typer af tekster der anvendtes af virksomheder inden for de forskellige områder. Undersøgelsen viste, at der i alle brancher var behov for at læse følgende typer af tekster: informerende, instruerende, udfyldnings- og opslagstekster samt tegn og symboler. De specifikke tekster, der skulle læses, varierede naturligvis mellem de forskellige brancher. Inden for metalområdet skulle der således fx læses maskinkataloger, manualer og skærmbilleder, mens de, der arbejdede inden for landtransportområdet, blandt andet skulle læse chaufførvejledninger og køreplaner samt skrive kørselsrapporter og kreditsedler.

6.4.1.2 Svensk undersøgelse af omfang, hyppighed og karakter af læsning og skrivning blandt industriarbejdere

Anna-Lena Gustavsson (2002) har gennemført en undersøgelse af otte svenske industriarbejdere med forskellige jobfunktioner. ${ }^{227}$ Hun lod blandt andet arbejderne føre dagbøger over deres læsning og skrivning i løbet af tre døgn. Endvidere blev der 24 gange i løbet af de tre undersøgte arbejdsdage ringet med en klokke som signal til de involverede arbejdere om at notere ned, hvad de foretog sig og hvilken slags læse- eller skriveaktivitet de eventuelt var i gang med. Endelig blev der gennemført interviews med arbejderne om læse- og skrivekravene. Gustavsson vurderede, at der generelt var god overensstemmelse mellem de oplysninger, der

\footnotetext{
${ }^{226}$ Munch-Hansen, T. \& Albæk, K. (1994). Faglæs - et analyse- og udviklingsprojekt om læsesvage i arbejdsmarkedsuddannelserne. København: Arbejdsmarkedsstyrelsen.

${ }^{227}$ Gustavsson, A-L. E. (2002). Att hantera läskrav i arbetet. Om industriarbetare med läs- och skrivsvårigheter. Linköpings universitet, Department of Behavioural Sciences.
} 
fremkom om de enkelte arbejderes læsning og skrivning gennem henholdsvis deres egne notater og interviewene, selv om flere af arbejderne oplyste, at de ikke havde noteret alle de udførte læse- og skriveopgaver, da det ville have forstyrret arbejdsprocessen for meget.

Dagbøgerne viste, at den tid, arbejderne rapporterede at bruge på læsning i løbet af de tre arbejdsdage, varierede fra to til 848 minutter. Antallet af tilfælde, hvor arbejderne havde noteret, at de havde læst noget, varierede ligeledes betydeligt. En enkelt arbejder havde således kun noteret ét tilfælde af læsning i løbet af de tre arbejdsdage, mens en af de andre i den samme periode havde noteret 142 tilfælde.

På basis af arbejdernes egne notater samt oplysninger fra de gennemførte interviews fandt Gustavsson, at arbejderne primært læste enkeltord, symboler og koder, som optrådte i kataloger, tabeller, køreplaner, kort, diagrammer, skemaer og kommandoer i computerprogrammer. Læsningen foregik typisk i korte sekvenser, var selektivt rettet mod at finde oplysninger i bestemte afsnit i de anvendte materialer og baseret på kendskab til materialerne og erfaringsbaseret viden. Deltagerne læste kun ganske sjældent længere sammenhængende tekster som $\mathrm{fx}$ manualer eller rapporter. Når arbejderne fik nye arbejdsopgaver, som stod beskrevet i sådanne længere tekster, blev opgaverne oftest gennemgået mundtligt af en instruktør eller en produktionsleder, således at teksterne ikke var den eneste informationskilde. Undersøgelsen viste desuden, at arbejderne kun skrev ganske sjældent og aldrig længere tekster. Når de skrev, drejede det sig typisk om korte sætninger, enkelte ord og koder.

Endvidere analyserede Gustavsson beskrivelser af nogle af industriarbejdernes jobs i hhv. 1965- og 1991-udgaven af „Dictionary of Occupational Titles“, som det amerikanske arbejdsministerium har udgivet. Gustavsson fandt ved at sammenholde arbejdsbeskrivelserne for de samme job fra hhv. 1965 og 1991 tegn på, at kravene til læsning var steget i den nævnte periode for de undersøgte jobs. Fx optræder der ifølge arbejdsbeskrivelsen fra 1965 i et af de udvalgte jobs krav om, at medarbejderen skal kunne kopiere og overføre informationer. Ifølge arbejdsbeskrivelsen fra 1991 for det pågældende job skal medarbejderen derudover kunne sammenstille og analysere informationer og data. Dette kan tolkes som et udtryk for, at kravene er steget i perioden 1965-1991.

\subsubsection{Amerikansk analyse af læsekrav ifølge arbejdsbeskrivelser}

Det amerikanske arbejdsministeriums beskrivelser af kravene i en række forskellige jobs er blevet analyseret og sammenholdt med de læsefærdighedsniveauer, der er blevet anvendt i både en national amerikansk læseundersøgelse (NALS) og OECD’s tidligere omtalte undersøgelse (S)IALS. ${ }^{228}$ I over 500 jobbeskrivelser blev kravene til læsning estimeret og tildelt et gennemsnitligt pointtal ud fra de færdighedsniveauer, der

\footnotetext{
${ }^{228}$ Barton, P. (2000). What jobs require: Literacy, Education, and Training 1940-2006. Policy Information Report. Educational Testing Service, Princeton NY.
} 
blev anvendt i de omtalte læseundersøgelser (jf. boksen nedenfor). Det fremgår af Bartons rapport om undersøgelsen, at langt de fleste jobs inden for forskellige brancher forudsatte læsefærdigheder svarende til niveau 3 eller derover. Imidlertid var der også en mindre gruppe af jobs, der „kun“ forudsatte læsefærdigheder svarende til niveau 2, fx jobs som truckfører, hjemmehjælper, sygehjælper og køkkenhjælper. Disse jobs var af en art, som typisk udføres af kortuddannede personer.

Skitse over skala og niveauer for opgaver i læseforståelse af fortløbende tekster i (S)IALS ${ }^{229}$

$\begin{array}{cl}\text { Niveau 1(0-225) } & \text { Læseren skal i teksten finde en enkelt oplysning, som er identisk eller } \\ & \text { synonym med den oplysning, der gives i instruktionen. } \\ \text { Niveau 2(226-275) } & \text { Læseren skal drage logiske slutninger på lavt niveau og integrere flere } \\ & \text { oplysninger i teksten. } \\ \text { Niveau 3 (276-275) } & \text { Læseren skal drage logiske slutninger på lavt niveau og sammenligne } \\ & \text { og kontrastere oplysninger på tværs af afsnit eller sektioner i teksten. } \\ \text { Niveau 4 (326-375) } & \text { Læseren skal drage logiske slutninger på højt niveau, integrere og } \\ & \text { kontrastere oplysninger i relativt lange tekster og behandle oplysninger } \\ & \text { med relativt abstrakt indhold. } \\ \text { Niveau 5 (376-500) } & \text { Læseren skal finde oplysninger i koncentreret tekst med en del afle- } \\ & \text { dende oplysninger. Læseren skal også foretage logiske slutninger på } \\ \text { højt niveau og gøre brug af specialviden. }\end{array}$

6.4.1.4 Nordiske spørgeundersøgelser vedrørende hyppighed og karakter af læsning og skrivning

I en analyse af de norske resultater fra SIALS fandt Gabrielsen (2000) som beskrevet i afsnit 3.3.3.1, at ufaglærte, som havde været i arbejde inden for det sidste år, generelt læste og skrev væsentligt mindre på jobbet end andre grupper, herunder faglærte håndværkere og akademikere. Som tabellen nedenfor viser, var det $\mathrm{fx}$ kun $27 \%$ af de ufaglærte, der mindst én gang om ugen læste et brev eller længere notat på jobbet, sammenlignet med $54 \%$ af de faglærte håndværkere og $96 \%$ af akademikerne. ${ }^{230}$

Som beskrevet i afsnit 3.2.3.2 og 3.6.3.1 er der rapporteret lignende resultater fra Danmark ${ }^{231}$ og Sverige ${ }^{232}$, hvor der tilsvarende ses en klar tendens til, at ufaglærte læser og skriver mindre i arbejdssammenhæng end personer med en uddannelse ud over grundskolen.

\footnotetext{
${ }^{229}$ Skitsen er et sammendrag af OECD’s beskrivelse af niveauerne for forståelse af fortløbende tekster („prose literacy“) i (S)IALS. Sammendraget er baseret på Annex A i: OECD (2000). Literacy in the Information Age: Final Report of the International Adult Literacy Survey. Paris: OECD. (pp. 93-106)

${ }^{230}$ Gabrielsen, E. (2000). Slik leser voksne i Norge. En kartlegging av leseferdigheten i aldersgruppen 16-65 år. Stavanger: Senter for læseforskning.

${ }^{231}$ Jensen, T.P., Andersen, A. \& Halgreen, T. (2001). Læeseferdigheder og deltagelse i samfundslivet. København: Amternes og Kommunernes Forskningsinstitut \& Specialarbejderforbundet i Danmark.

${ }^{232}$ Gustavsson, A-L.E. (1997). Att läsa - ett behov, ett krav, en nödvändighet. En analys av den första internationellt jämförande studien av vuxnas förmåga att förstå och använda skriftlig information. International Adult Literacy Survey. Linköpings universitet: Institutionen för pedagogik och psykologi.
} 
Tabel 12: Brug af læsning og skrivning på arbejdet blandt norske SIALS-deltagere ${ }^{233}$

\begin{tabular}{lccc}
\hline $\begin{array}{l}\text { Arbejder mindst én gang om ugen på jobbet med følgende } \\
\text { opgave }\end{array}$ & Ufaglærte & $\begin{array}{c}\text { Faglærte } \\
\text { håndværkere }\end{array}$ & Akademikere \\
\hline Læser brev eller længere notat & $27 \%$ & $54 \%$ & $96 \%$ \\
Læser rapporter eller artikler & $16 \%$ & $51 \%$ & $91 \%$ \\
Læser manualer, håndbøger eller kataloger & $17 \%$ & $46 \%$ & $59 \%$ \\
Læser diagrammer eller skemaer & $13 \%$ & $42 \%$ & $65 \%$ \\
Læser regninger, fakturaer eller budgetter & $13 \%$ & $19 \%$ & $38 \%$ \\
Læser skriftlig information på andet sprog end norsk & $13 \%$ & $21 \%$ & $38 \%$ \\
Læser vejledninger eller instruktioner & $4 \%$ & $4 \%$ & $49 \%$ \\
Skriver brev eller længere notat & $10 \%$ & $23 \%$ & $80 \%$ \\
Skriver formularer, regninger, fakturaer eller budget & $7 \%$ & $16 \%$ & $25 \%$ \\
Skriver rapporter eller artikler & $6 \%$ & $14 \%$ & $39 \%$ \\
Skriver tekniske vurderinger eller specifikationer & $4 \%$ & $21 \%$ & $20 \%$ \\
\hline
\end{tabular}

6.4.1.5 Amerikansk undersøgelse af betydningen og karakteren af læsning og skrivning på virksomheder

Hull, Jury, Ziv \& Katz (1996) har afdækket brugen af læsning og skrivning på forskellige typer af virksomheder i USA, blandt andet inden for elektronikindustrien. ${ }^{234}$ Afdækningen er foretaget gennem observationer i virksomhederne og interviews med ledere og medarbejdere. Det vurderes på denne baggrund, at kravene til læse- og skrivefærdigheder er steget i de senere år, men at de øgede krav typisk ikke udspringer fra selve udførelsen af jobfunktionen, men snarere fra aktiviteter, der foregår „,rundt om“ jobfunktionen, som fx deltagelse i møder, planlægning af arbejdsprocesser, kvalitetskontrol og dokumentation af fejl, som kan være forbundet med omfattende læsning og skrivning. Det fremgår af rapporten, at læsning og skrivning på moderne arbejdspladser kan spille en vigtig rolle for medarbejdernes muligheder for at få indflydelse på deres egen arbejdssituation.

6.4.1.6 Svensk undersøgelse af betydningen og karakteren af læsning og skrivning i forskellige erhverv

I Sverige har Anna-Malin Karlsson undersøgt, hvilken rolle anvendelse af læsning og skrivning spillede inden for jobs som sygehjælper, bygningsarbejder, truckchauffør, butiksassistent, børnehaveklasselærer, IT-support-specialist og mekaniker. ${ }^{235}$ Undersøgelsen er baseret på case-studies

\footnotetext{
${ }^{233}$ Tabellen er udarbejdet på basis af data fra Gabrielsen, E. (2000). Slik leser voksne i Norge. En kartlegging av leseferdigheten i aldersgruppen 16-65 år (pp. 77-78). Stavanger: Senter for læseforskning.

${ }^{234}$ Hull, G., Jury, M., Ziv, O. \& Katz, M. (1996). Changing work, changing literacy: A study of skill requirements and development in a traditional and restructured workplace (Final Report). Berkeley, CA: National Center for Research in Vocational Education, Center for the Study of Writing and Literacy.

${ }^{235}$ Karlsson, A. (2006). Reading to be independent, writing to be controlled? Roles and literacies offered to workers in modern organisations. Stockholm: Stockholms Universitet, Institutionen för nordiska språk. (http://www.nordiska.su.se/skriftbruk/Karlsson_Reading to be Independent.doc)
} 
af en eller to personer, der bestred de nævnte jobs. ${ }^{236}$ Karlsson fandt, at læsning og skrivning oftest indgik i forbindelse med planlægning, orientering og dokumentation. Fx viste observationer af to sygehjælpere på et plejehjem, at de ved starten af deres vagt læste informationer om, hvad der var sket blandt patienterne på hjemmet, mens de ved slutningen af deres vagt skrev for at dokumentere og videregive informationer til dem, der overtog den følgende vagt. Omtrent parallelt hermed læste en truckchauffør ved starten af sin arbejdsdag med henblik på at planlægge sit arbejde med at transportere materialer, og ved slutningen af arbejdsdagen skrev han for at dokumentere, hvad han havde udført den dag.

6.4.1.7 Dansk udviklingsarbejde vedrørende betydningen og karakteren af læsning og skrivning inden for udvalgte brancher

I Danmark har FVU-team Storkøbenhavn udviklet en vejledning for konsulenter og undervisere, der laver opsøgende arbejde med henblik på at starte kurser inden for den forberedende voksenundervisning (FVU). ${ }^{237} \mathrm{I}$ forbindelse med udarbejdelsen af vejledningen er kravene til læsning og skrivning blevet skitseret inden for en række forskellige brancher, herunder lager og transport, bygge og anlæg, kontor, service samt social- og sundhedsområdet. Udviklingsarbejdet er blevet udført på basis af møder i såkaldte fokusgrupper bestående af repræsentanter for de forskellige brancher, herunder uddannelsesansvarlige og tillidsrepræsentanter.

Inden for social- og sundhedsområdet fokuseres der i vejledningsmaterialet på arbejdet i hjemmeplejen, hvor der stilles store krav til den enkelte social- og sundhedshjælper om skriftlig dokumentation af det udførte arbejde. Eksempelvis skal det kunne begrundes skriftligt, hvis der skal foretages ændringer i en procedure, herunder tilmålingen af den tid, medarbejderen bruger hos de enkelte borgere inden for hjemmeplejen. Ligeledes har indførelse af selvstyrende teams mange steder medført megen læsning og skrivning i forhold til tidligere. Der nævnes i vejledningen følgende læse- og skriveopgaver inden for hjemmeplejen:

- Skrivning af indkøbssedler og huskesedler

- Skrivning af meddelelser til pårørende, borgeren, kolleger og overordnede

- Læsning af arbejdsplaner, køreplaner, lønsedler og andre skemaer

- Læsning af brugsanvisninger og vejledninger vedrørende rengøring, opbevaring af madvarer m.m.

- Læsning og evt. skrivning af mødereferater

- Dokumentation og nedskrivning af klienttid, herunder beskrivelse af arbejdsopgaver

\footnotetext{
${ }^{236}$ Karlsson, A. (2005). Goods, services and the role of written discourse. In: Gunnarsson, B. (ed.). Communication in the Workplace. (pp. 91-104) Uppsala: Uppsala University.

${ }^{237}$ Pedersen, L.B.T. \& Løvengreen, K. (2006). Brancherettet FVU - et idékatalog om information og tilrettelæggelse af FVU på virksomheder. København: FVU-team Storkøbenhavn. (http://www.fvu-team.dk/pdf/opsoegerkatalog_samlet.pdf)
} 
- Skrivning i kommunikationsmapper hos borgeren, fx livshistorier

- Kardex-skrivning

6.4.1.8 Canadisk undersøgelse af betydningen af læsning og skrivning på arbejdspladser

Belfiore, Defoe, Folinsbee, Hunter \& Jackson (2004) har med henblik på at afdække brugen af læsning og skrivning gennemført en række casestudies på forskellige canadiske arbejdspladser, herunder flere fabrikker og et hotel. ${ }^{238}$ Forskergruppen har gennem flere måneder gennemført observationer og foretaget interviews med ledere og medarbejdere på de enkelte arbejdspladser. På basis heraf vurderer gruppen blandt andet, at læsning og skrivning ofte tillægges en anden betydning af de menige medarbejdere end af ledelsen. Eksempelvis fandt Belfiore og hendes kolleger, at mange arbejdere oplevede at få modstridende meldinger fra ledelsen om betydningen af $\mathrm{fx}$ at udfylde papirer i forbindelse med produktion og kvalitetssikring. For at kunne opfylde kravene om produktivitet undlod nogle arbejdere at udfylde de blanketter, som det formelt set krævedes af dem, da de havde fået det indtryk, at et højt produktionstempo reelt var langt mere afgørende for en succesfuld udførelse af arbejdet end udfyldning af papirer. I et enkelt tilfælde berettes det, at nogle medarbejdere for at spare tid ligefrem begyndte deres arbejde med at sætte en række krydser på de blanketter, som egentlig først skulle udfyldes som en kontrol af, at arbejdet var udført korrekt. I andre tilfælde undlod medarbejdere at udarbejde fejlrapporter trods pålæg fra ledelsen, fordi medarbejderne frygtede, at sådanne rapporter ville medføre, at de selv eller deres kolleger ville blive bebrejdet på grund af fejlene.

6.4.1.9 Afdækning af læse- og skrivekrav på arbejdspladser ved hjælp af „Literacy Task Analysis“

Der er i USA udviklet og afprøvet forskellige metoder til afdækning af læse- og skrivekrav på arbejdspladser. Blandt de vigtigste er Literacy Task Analysis, som sigter mod at afdække kravene til læsning og skrivning inden for vigtige arbejdsopgaver, hvor arbejderne ofte har vanskeligheder med at udføre læse- og skrivefunktioner. Afdækningen skal danne grundlag for planlægning af indholdet af et arbejdsrelateret læse- og skrivekursus. Fremgangsmåden i metoden er beskrevet i lidt forskellige versioner, men i det følgende gengives hovedtrækkene i metoden på basis af Philippis arbejde. ${ }^{239}$ På en given arbejdsplads nedsættes først en gruppe af personer med kendskab til læse-skriveundervisning samt udvalgte dygtige medarbejdere. Denne gruppe får til opgave at udpege de arbejdsområder, hvor medarbejdere typisk har vanskeligheder med læse- og skriveopgaver. Derefter gennemlæser undervisningsplanlæggeren ar-

\footnotetext{
${ }^{238}$ Belfiore, M. E., Defoe, T. A., Folinsbee, S., Hunter, J. \& Jackson, N. S. (2004). Reading Work. Literacies in the New Workplace. Mahwah: New Jersey: Lawrence Erlbaum Associates.

${ }^{239}$ Philippi, J.W. (1991). Literacy at work. The workbook for program developers. New York: Simon \& Shuster Workplace Resources.
} 
bejdsbeskrivelser og arbejdsmaterialer og foretager observationer af, hvordan de udvalgte dygtige medarbejdere udfører de udpegede kritiske opgaver. Disse medarbejdere udspørges om arbejdsopgaverne og de dermed forbundne kognitive og mentale processer. I løbet af sine besøg på arbejdspladsen indsamler undervisningsplanlæggeren de materialer, som anvendes. Hver enkelt af de observerede arbejdsopgaver analyseres med henblik på at identificere, hvilke læse- og skrivefærdigheder der skal anvendes for at løse den pågældende opgave. Fx kan en medarbejder have som en af sine opgaver at udfylde et skema med bestemte oplysninger, som findes rundt omkring på sedler, der sidder på forskellige maskiner på arbejdspladsen. Denne opgave indebærer blandt andet, at medarbejderen skal læse de forskellige sedler igennem med henblik på at finde de relevante oplysninger, sortere de irrelevante fra samt indskrive de krævede oplysninger nøjagtigt i skemaet.

Philippi anbefaler, at de personer, der er ansvarlige for arbejdspladsrelaterede læse- og skriveforløb, spørger sig selv: „Hvad er det, jeg skal gøre for at få den nødvendige information, når jeg læser disse arbejdsmaterialer?“ ${ }^{240}$ På basis af svarene på dette spørgsmål kan der udvikles en liste over de mentale procedurer, som er involveret i effektiv udførelse af bestemte læseopgaver på jobbet. Denne liste kan fungere som en vejledning, når deltagerne i forbindelse med læse- og skriveundervisningen skal arbejde med at udvikle hensigtsmæssige læsestrategier. Underviseren kan da med udgangspunkt i denne liste vise deltagerne, hvordan de kan implementere de identificerede processer i deres arbejdslæsning.

6.4.1.10 Afdækning af læse- og skrivekrav på arbejdspladser ved hjælp af „Job Literacy Analysis“

Metoden Job Literacy Analysis er udviklet og beskrevet af Norback og sigter mod at identificere alle basale færdighedsområder i de jobs, der analyseres. ${ }^{241}$ Ved anvendelse af metoden foretages der indledningsvis interviews med medarbejdere, som viser eksempler på de vigtigste materialer, de anvender på jobbet, og forklarer, hvordan disse materialer bruges. Derefter foretages der en analyse af, hvilke læse- og skrivefærdigheder der kræves for at udføre de beskrevne arbejdsopgaver. Fx kan en sekretær have som opgave at læse korrektur på arbejdspladsens nyhedsbrev. På basis af analysen vurderes det, at sekretæren for at udføre denne opgave blandt andet måtte besidde færdigheder $\mathrm{i}$ at anvende regler for tegnsætning og kontrollere ords stavemåde ved hjælp af ordbogsopslag eller lignende. Resultaterne af analyserne gennemses af en ledergruppe, som kontrollerer, at alle vigtige materialer, opgaver og færdigheder er inddraget. Der udarbejdes en rapport, som sammenfatter, hvilke typer af færdigheder der kræves til forskellige arbejdsopgaver og materialer. Endelig

\footnotetext{
${ }^{240}$ Philippi, J. W. (1988). Matching literacy to job training: Some applications from military programs. Journal of Reading, 31(7), pp. 658-666.

${ }^{241}$ Norback, J.S. (1998). Literacy Skills Analysis for Job Training. University of Pennsylvania: National Center on Adult Literacy.
} 
identificeres de færdigheder, som ofte skal bruges i forskellige jobs med henblik på udvikling af et læse- og skrivekursus, som går på tværs af jobgrupperinger. Til identifikation af disse tværgående færdigheder kan anvendes et særligt udviklet software-program.

I metoden Job Literacy Analysis indgår observationer, interviews og analyser af materialer som centrale elementer i en afdækning af arbejdsrelaterede læse- og skrivekrav. Herved ligner metoden den førnævnte Literacy Task Analysis. Samtidig har de to metoder dog lidt forskellige fokus og tilgange. Job Literacy Analysis har således som nævnt til formål at identificere alle de læse- og skriverelaterede færdigheder, der er nødvendige i de undersøgte jobs, hvorved metoden adskiller sig fra Literacy Task Analysis, som har til formål at identificere særligt kritiske arbejdsrelaterede læse- og skriveopgaver. Endvidere lægger Literacy Task Analysis til forskel fra Job Literacy Analysis vægt på at beskrive de krævede færdigheder ud fra de kognitive processer, som bruges af dygtige arbejdere til at udføre opgaver. Ifølge Norback kan det i forbindelse med udvikling af et læse- og skrivekursus i praksis være en fordel at kombinere elementer fra de to metoder.

\subsubsection{Tidligere undersøgelser af medarbejderes færdigheder i og} forudsctninger for lasning og skrivning i arbejdssammenhæeng

6.4.2.1 Amerikansk undersøgelse af færdigheder i jobrelateret læsning og skrivning blandt sygehjælpere

I USA har Dolores Perin (1997) undersøgt effekten af arbejdsrelaterede læse- og skrivekurser for 389 sygehjælpere, som i deres arbejde blev stillet over for store krav vedrørende blandt andet skriftlig dokumentation. ${ }^{242}$ I den forbindelse gennemførtes test af kursusdeltagernes færdigheder på en række områder før og efter undervisningsforløbene. I testbatteriet indgik der blandt andet en almen test af læseforståelse af overvejende informerende dagligdags tekster samt en test af deltagernes generelle vurdering af sig selv. Desuden blev der anvendt flere test, der var udviklet specielt til projektet og var direkte relateret til deltagernes arbejde som sygehjælpere. Blandt disse var en test af læseforståelse af en tekst, hvori en patients sygehistorie og behandlingsplan blev beskrevet. Endvidere indgik der en skrivetest, hvor deltagerne blev bedt om at give en skriftlig beskrivelse af den vanskeligste eller mest interessante patient, de havde mødt. Der blev foretaget en vurdering af deltagernes skriftlige produkter med hensyn til blandt andet organisering, indhold, sprogbrug, ordvalg og stavning. Endelig gennemgik deltagerne før og efter kurset en test, der afdækkedes deres egen vurdering af deres færdigheder i at udføre en række læse- og skriverelaterede arbejdsfunktioner ved hjælp af spørgsmål som „Hvor sikker er du på, at du kan forstå en patients behandlings-

\footnotetext{
${ }^{242}$ Perin, D. (1997). Workplace Literacy Assessment. Dyslexia (3), pp. 190-200.
} 
plan?“. Undersøgelsen viste, at der var signifikant fremgang i deltagernes resultater på fem ud af de seks ovenfor nævnte mål, herunder alle de arbejdsrelaterede test. Det eneste mål, hvor der ikke kunne påvises signifikante fremgange, var på den almene test af læseforståelse af dagligdags tekster.

6.4.2.2 Amerikansk undersøgelse af færdigheder i jobrelateret læsning blandt medarbejdere på virksomheder

Mikulecky \& Lloyd (1997) har som nævnt i afsnit 5.4 vurderet kvaliteten af en række forskellige arbejdsrelaterede tilbud om læse- og skriveundervisning. ${ }^{243}$ I alt 180 medarbejdere fra 10 forskellige arbejdspladser gennemførte før og efter deres deltagelse i læse- og skriveundervisning nogle test, der blandt andet afdækkede færdigheder i at forstå arbejdsrelaterede tekster. Der blev for de ti arbejdspladser udformet parallelle opgaver til forskellige tekster, der var specifikke for hver af de pågældende arbejdspladser. Blandt teksterne indgik blandt andet nyhedsbreve og diagrammer fra de undersøgte arbejdspladser. Deltagerne fik stillet spørgsmål til teksterne, der afdækkede, i hvilken grad de kunne finde faktuelle oplysninger i teksterne, drage følgeslutninger på basis af det læste og anvende det i praksis. Deltagerne blev desuden bedt om at beskrive, hvilke strategier de brugte i forbindelse med læsning af udvalgte tekster. Undersøgelsen viste blandt andet, at deltagernes fremgange på de arbejdspladsrelaterede læseforståelsesopgaver især var betinget af, at en vis del af de anvendte materialer var arbejdsrelaterede. Endvidere udviklede de deltagere, som brugte en stor del af undervisningstiden på læsning og skrivning, mere sofistikerede læsestrategier end andre.

\subsection{Diskussion vedrørende krav til og færdigheder i læsning og skrivning}

I kapitel 6 er der givet en oversigt over relevante undersøgelser, som har belyst læse- og skrivekrav samt individers færdigheder i og forudsætninger for læsning og skrivning i uddannelses- eller arbejdssammenhæng.

I uddannelsessammenhceng har tidligere undersøgelser vist, at unge og voksnes forståelse af uddannelsestekster i høj grad synes at være relateret til deres generelle niveau af læse- og skrivefærdigheder. Endvidere kan forskelle i deltagernes kendskab til uddannelsesrelaterede fagord og uddannelsesrelevante joberfaring bidrage til en „forklaring“ af spredningen i deltagernes færdigheder i uddannelsesfaglig læsning, selv efter at der er taget højde for forskelle i det generelle læsefærdighedsniveau. Både kendskab til uddannelsesrelevante fagord og uddannelsesrelevant joberfaring kan siges at være udtryk for kendskab til uddannelsens faglige områ-

\footnotetext{
${ }^{243}$ Mikulecky, L. \& Lloyd, P. (1996). Evaluation of Workplace Literacy Programs: a Profile of Effective Instructional Practices. Journal of Literacy Research, 29(4), 555-585.
} 
de. De nævnte resultater kan derfor samlet tolkes som et udtryk for, at et sådant kendskab i høj grad er relateret til deltageres udbytte af fagtekster i uddannelsessammenhæng.

Andre undersøgelser viser, at oplevede læsevanskeligheder langtfra kun afhænger af det faktiske niveau af læsefærdigheder, men i høj grad også af de krav, der stilles til den enkelte. ${ }^{244} 245$ Dette betyder i praksis, at en person med et bestemt læsefærdighedsniveau kan opleve store vanskeligheder i en bestemt uddannelse, hvor læsning er en vigtig kilde til læring. Derimod vil en person med et tilsvarende læsefærdighedsniveau sandsynligvis ikke opleve nær så store vanskeligheder i en anden uddannelse, hvor det faglige stof reelt kan tilegnes på andre måder end gennem læsning.

Om de reelle læsekrav i en given uddannelse er høje eller lave, vil ikke blot afhænge af omfanget og karakteren af læseopgaverne, men også af, hvor afgørende læsning er som kilde til tilegnelse af faglig viden. I nogle uddannelser kompenseres der således i praksis betydeligt for det læsestof, der formelt set er pensum, idet det som fx på nogle arbejdsmarkedsuddannelser i en vis udstrækning er muligt for deltagerne at tilegne sig den nødvendige faglige viden på anden vis end gennem læsning (jf. afsnit 6.3.1.1). ${ }^{246}$ En vurdering af læsekravene i en given uddannelse bør tage højde for sådanne faktorer, således at det bliver de reelle læsekrav og ikke blot de formelle, der afdækkes. I kapitel 7 gives der nogle konkrete forslag til, hvordan der i kommende nordiske projekter kan arbejdes videre med at afdække læsekrav i uddannelsessammenhæng.

På nogle måder kan det forekomme (endnu) vanskeligere at afdække læse- og skrivekrav i arbejdssammenhæeng end i uddannelsessammenhæng, blandt andet fordi det ofte er svært at afgøre, hvor meget materiale der faktisk skal læses eller skrives i et givent job. Erfaringer fra tidligere undersøgelser viser, at de menige medarbejderes beskrivelser af læse- og skrivekravene i en del tilfælde afviger fra de overordnedes beskrivelser. ${ }^{247}$. Der kan være adskillige forklaringer på de divergerende opfattelser af læse- og skrivekravene. I det følgende nævnes nogle af de mest oplagte:

- Der kan være misforståelser og mangelfuld kommunikation mellem arbejdsledere og underordnede medarbejdere.

\footnotetext{
${ }^{244}$ Dansk Videnscenter for Ordblindhed (2006). Rapport om afprøvning af visitationstest til brug i ordblindeundervisning for voksne. København: Undervisningsministeriet. (http://us.uvm.dk/voksen/fvu/documents/endelig_rapport.doc)

${ }^{245}$ Elbro, C., Møller, S. \& Nielsen, E. M. (1991). Danskernes læsefærdigheder. En undersøgelse af 18 - 67-åriges laesning af dagligdags tekster. København: Projekt Læsning og Undervisningsministeriet.

${ }^{246}$ Lund, K., Bertelsen, E. \& Sørensen, M.S. (2006). Muligheder og barrierer - en undersøgelse af overgangen mellem sprogcentre og erhvervsrettede uddannelser. København: Ministeriet for Flygtninge, Indvandrere og Integration. (http://www.nyidanmark.dk/NR/rdonlyres/01C5917D-422249C4-9BA2-8BEB58800ECA/0/Muligheder barrierer.pdf)

${ }^{247}$ Belfiore, M. E., Defoe, T. A., Folinsbee, S., Hunter, J. \& Jackson, N. S. (2004). Reading Work. Literacies in the New Workplace. Mahwah: New Jersey: Lawrence Erlbaum Associates.
} 
- Nogle medarbejderes læse- og skrivefærdigheder slår ikke til i forhold til opgaverne, og sådanne medarbejdere kan derfor forsøge at klare opgaverne ved fx at spørge kolleger om hjælp frem for selv at læse og skrive.

- Nogle medarbejdere er ikke selv bevidste om, hvordan og hvornår læsning og skrivning indgår som en del af arbejdsprocessen, og kan derfor ikke give en fyldestgørende redegørelse.

- Medarbejdere kan bevidst undlade at udføre pålagte læse- og skriveopgaver, $\mathrm{fx}$ for at beskytte sig selv eller kolleger mod den kritik, som udarbejdelse af eventuelle fejlmeddelelser kan føre til.

På basis af det ovenstående kan det konkluderes, at det er utilstrækkeligt at foretage en analyse af læse- og skrivekrav udelukkende på basis af oplysninger fra enten de enkelte medarbejdere eller deres overordnede. En analyse bør omfatte oplysninger fra begge parter vedrørende både omfanget, karakteren og betydningen af læsning og skrivning i forbindelse med de funktioner, som de enkelte medarbejdere udfører. Derudover forekommer det oplagt, at en forsker eller en undervisningsplanlægger vil opnå et mere præcist billede af læse- og skrivekravene i en given arbejdssammenhæng, hvis han faktisk observerer konkrete arbejdssituationer og analyserer de anvendte materialer frem for blot at få forskellige personer til at beskrive deres opfattelser af kravene.

I kapitel 7 gives der nogle forslag til, hvordan der i kommende nordiske projekter kan arbejdes videre med at afdække læse- og skrivekrav samt individers færdigheder i og forudsætninger for læsning og skrivning i uddannelses- og arbejdssammenhæng. 



\section{Forslag til kommende projekter}

\subsection{Sammenfatning}

I Norden findes der mange forskellige tilbud og tiltag, som retter sig mod kortuddannede med utilstrækkelige læse- og skrivefærdigheder. Der savnes imidlertid undersøgelser, der viser, om tiltagene faktisk har en positiv effekt på deltagernes færdigheder. På denne baggrund fremsættes der et forslag, som har til formål at undersøge effekten af et særligt tilrettelagt læse- og skriveundervisningsforløb, hvor der tages udgangspunkt i de krav, deltagerne møder i deres arbejde eller uddannelse (jf. projektforslag I i afsnit 7.3).

Der savnes endvidere retningslinjer for, hvordan læse- og skrivekrav kan afdækkes og synliggøres på en systematisk måde, lige som der er brug for velafprøvede metoder til at identificere de personer, der har vanskeligheder med at leve op til disse krav. Der fremsættes derfor et forslag til et projekt, som kan bidrage til udvikling af sådanne retningslinjer og metoder i uddannelsessammenhæng (jf. projektforslag II i afsnit 7.4).

\subsection{Indledning}

Som det fremgår af rapporten om den nordiske forundersøgelse, findes der i de nordiske lande en række tilbud og tiltag, som er rettet mod unge og voksne med læse- og skrivevanskeligheder i både arbejds- og uddannelsessammenhæng (jf. kapitel 4). Der foreligger imidlertid kun yderst sjældent overbevisende dokumentation for, at de forskellige tiltag faktisk fører til en forbedring af deltagernes læse- og skrivefærdigheder. Oftest er virkningen af tiltagene udelukkende blevet vurderet på basis af udsagn fra deltagerne og underviserne om deres oplevelse af udbyttet. På grundlag af sådanne oplysninger kan man imidlertid ikke vide, hvorvidt deltagerne objektivt set har forbedret deres færdigheder i læsning og skrivning, da det ikke er blevet afdækket, om der er sket en målbar udvikling i disse færdigheder.

Der er som led i forundersøgelsen gennemført observationer og indsamlet oplysninger vedrørende tre udvalgte nordiske eksempler på undervisningstiltag for voksne med læse- og skrivevanskeligheder (jf. kapitel 5). Der er i alle tre tilfælde tale om tiltag, som i national sammenhæng har vakt opmærksomhed og opnået et godt ry. Der er imidlertid ved ingen af disse tiltag foretaget en systematisk og dækkende undersøgelse af ud- 
viklingen i deltagernes færdigheder i løbet af undervisningen. Det er derfor vanskeligt at vide, om de pågældende undervisningstiltag faktisk medfører en forbedring af deltagernes færdigheder, og om en sådan forbedring i givet fald er større end den, deltagerne kunne have opnået gennem andre undervisningstiltag.

Når de tre udvalgte tiltag i lighed med forskellige andre tiltag har opnået et godt ry, kan det skyldes mange forskellige faktorer, fx anvendelsen af en bestemt undervisningsmetode, underviserens engagement, organiseringen af undervisningen, rekrutteringen af deltagerne eller udbyderens evne til at udbrede kendskabet til det pågældende tiltag. Det er med andre ord uklart, hvad det er ved de givne tiltag, der får dem til at fremstå som en succes, og derfor er det også uklart, hvilke elementer det eventuelt kunne være relevant at kopiere og overføre til andre sammenhænge. Hvis det fx i virkeligheden primært er en enkelt undervisers særlige engagement, der er årsag til et tiltags gode ry, kan det ikke forventes, at konceptet i det pågældende tiltag med succes vil kunne overføres til andre sammenhænge med andre undervisere.

Hvis man vil vide, om en bestemt type undervisning fører til bedre resultater end andre typer undervisning og derfor er værd at forsøge at overføre til andre sammenhænge, er den mest sikre vej til at opnå denne viden at gennemføre en egentlig effektundersøgelse. En sådan undersøgelse kan belyse, om deltagere i en særlig type undervisning opnår større fremgang i færdigheder end deltagere, som modtager en anden undervisning. Før og efter undervisningsforløbet gennemføres der test af de relevante færdigheder hos den gruppe deltagerne, som modtager den særlige undervisning. En kontrolgruppe, som ikke deltager i denne undervisning, gennemfører de samme test. På basis af en sammenligning af udviklingen i færdigheder i de forskellige grupper kan det vurderes, om den særlige undervisning faktisk medfører en fremgang i deltagernes færdigheder, som er større end fremgangen hos kontrolgruppen. Hvis det viser sig at være tilfældet, er der grundlag for at antage, at også andre end forsøgsdeltagerne vil kunne drage nytte af den særlige undervisning. Sådanne undersøgelser findes der næsten ingen af i Norden, selv om der på basis heraf kan opnås værdifuld information om, hvad der virker i undervisningen. Afsnit 7.3 indeholder et forslag til en kommende effektundersøgelse af læse- og skriveundervisning (projektforslag I).

Som oversigten i rapporten viser, er der i alle de nordiske lande blandt kortuddannede en stærk overrepræsentation af personer med ringe læsefærdigheder (jf. kapitel 3). En del af disse personer kan formodes at have svært ved at opfylde de krav, der stilles til læsning og skrivning i arbejde og uddannelse. Det forekommer hensigtsmæssigt at afdække og synliggøre disse krav. En afdækning af kravene kan således blandt andet være nyttig som grundlag for tilrettelæggelse af en læse- og skriveundervisning, der tager udgangspunkt i de læse- og skrivekrav, deltagerne møder i deres daglige arbejde eller uddannelse. En synliggørelse af kravene kan 
blandt andet være til nytte i forbindelse med vejledning af personer med svage læse- og skrivefærdigheder.

En afdækning og synliggørelse af læse- og skrivekravene bør ikke stå alene, men kobles sammen med en afdækning af, hvem der har vanskeligheder med at opfylde disse krav, således at disse personer kan tilbydes relevant vejledning og støtteforanstaltninger. Afsnit 7.4 indeholder derfor et forslag til et projekt, der kombinerer udviklingen af metoder til afdækning og synliggørelse af læse- og skrivekrav med udviklingen af en procedure til identifikation af personer, som har vanskeligheder med at opfylde disse krav (projektforslag II).

\subsection{Projektforslag I: Undersøgelse af effekt af fagrelateret læse-skriveundervisning}

\subsubsection{Baggrund}

Mange kortuddannede med ringe læse-skrivefærdigheder er tilbageholdende med at deltage i kurser og uddannelse, hvilket blandt andet kan skyldes tidligere dårlige erfaringer og nederlag i forbindelse med skolegang. Det kan ikke tages for givet, at sådanne personer uden videre vil melde sig til et generelt læse-skrivekursus, som fokuserer på netop det, de har vanskeligheder med, nemlig læsning og skrivning. Hvis denne gruppe skal motiveres til at forbedre deres læse- og skrivefærdigheder, kan det være mere hensigtsmæssigt at tilrettelægge undervisningen, så den tager udgangspunkt i deltagernes fagområde og de krav, som de møder til daglig i enten arbejds- eller uddannelsesmæssig sammenhæng.

I arbejdssammenhœeng kan en fagrelateret læse-skriveundervisning tage udgangspunkt i de tekster, som medarbejderne skal læse og skrive som led i deres arbejde. Som rapporten viser, foregår der i de nordiske lande læse- og skriveundervisning på en del arbejdspladser (jf. kapitel 4 og 5). De indsamlede data fra det nordiske forprojekt tyder imidlertid på, at det ikke er nogen selvfølge, at en sådan undervisning er direkte koblet til deltagernes daglige arbejde og de tekster, der anvendes her. Dette kan muligvis skyldes, at undervisere på læse-skrivekurser typisk ikke selv har erfaring med den type arbejde, som deltagerne udfører i deres dagligdag og derfor ikke har kendskab til de læse- og skrivekrav, deltagerne møder. Uden en grundig afdækning af disse krav kan det være vanskeligt for underviserne at tilrettelægge en læse-skriveundervisning, der er direkte relateret til deltagernes arbejde.

I uddannelsessammenhæeng kan en fagrelateret læse-skriveundervisning tage udgangspunkt i deltagernes læsning og skrivning af faglige tekster, således at denne undervisning støtter gennemførslen af den uddannelse, som deltagerne er i gang med. Tilrettelæggelse af en sådan læse-skriveundervisning forudsætter imidlertid, at underviserne på de 
forskellige uddannelser har viden om, hvordan de kan vejlede deltagerne i at læse og skrive forskellige typer af fagtekster.

\subsubsection{Formål}

Projektet har til formål:

1. At udvikle og afprøve en fremgangsmåde til analyse af specifikke uddannelses- eller arbejdsrelaterede læse- og skrivekrav.

2. At udvikle og afprøve et undervisningsforløb, der tager udgangspunkt i tekster, som deltagerne har behov for at læse og skrive i deres uddannelse eller arbejde.

3. At undersøge effekten af et sådant undervisningsforløb på deltagernes læse- og skrivefærdigheder.

\subsubsection{Metode}

Der udvælges en uddannelse eller et erhverv, hvor læsning og/eller skrivning spiller en væsentlig rolle. Der foretages en analyse af læse- og skrivekravene inden for den udvalgte uddannelse eller det udvalgte erhverv. Med henblik på at afdække karakteren af de læse- og skriveopgaver, der skal udføres, analyseres de anvendte materialer, lige som der gennemføres observationer af arbejds- eller undervisningssituationer samt interviews med relevante personer. Disse personer vil i arbejdssammenhæng typisk være ansatte inden for det valgte erhverv samt deres overordnede, mens det i uddannelsessammenhæng vil være undervisere og deltagere.

På basis af resultaterne af analysen af læse- og skrivekravene udarbejdes der et træningsprogram, som sigter mod at udvikle deltagernes færdigheder $\mathrm{i}$ at læse og/eller skrive de vigtigste af de teksttyper, der indgår i deres uddannelse eller arbejde. Før og efter træningsforløbet gennemføres der blandt forsøgsdeltagerne en afdækning af deres læse- og skrivefærdigheder ved hjælp af såvel almene som fagspecifikke test. Endvidere afdækkes deltagernes subjektive vurdering af deres færdigheder i at læse og skrive forskellige typer af tekster. I undersøgelsen indgår også en kontrolgruppe, som har det samme erhverv eller deltager i den samme uddannelse som forsøgsdeltagerne. Denne kontrolgruppe gennemfører de samme test og besvarer det samme spørgeskema som forsøgsgruppen, men deltager ikke i det særlige træningsprogram. På basis af en sammenligning af resultaterne i de forskellige grupper kan der foretages en vurdering af, om det særlige træningsprogram har en særlig effekt på deltagernes færdigheder i at læse og/eller skrive almene og fagspecifikke tekster. 


\subsubsection{Perspektiver}

Formodentlig vil analysen af læse- og skrivekrav i den udvalgte uddannelse eller det udvalgte erhverv kunne tjene som illustrativt eksempel og danne en del af grundlaget for et videre arbejde med at analysere læse- og skrivekrav i andre uddannelser eller erhverv. Hvis der kan påvises positive resultater af forsøgsundervisningen, vil undervisningsmetoderne $\mathrm{i}$ modificeret form kunne overføres og anvendes i forbindelse med læseskriveundervisning for andre uddannelses- eller erhvervsgrupper, både i det land, hvor undersøgelsen gennemføres, og i de øvrige nordiske lande.

Der kan eventuelt gennemføres effektundersøgelser i flere nordiske lande inden for den ovenfor skitserede ramme. I så fald kan undersøgelserne fokusere på forskellige metoder og målgrupper, således at hver af undersøgelserne kan bidrage med ny indsigt, som senere kan overføres til andre sammenhænge.

\subsection{Projektforslag II: Udvikling af metoder til afdækning af uddannelsesrelaterede læse- og skrivekrav samt deltageres færdigheder}

\subsubsection{Baggrund}

Resultater fra tidligere undersøgelser tyder på, at det langtfra blot er en persons faktiske niveau af læsefærdigheder, der afgør, om han oplever vanskeligheder i dagligdagen. Om en person oplever vanskeligheder, afhænger i høj grad også af de krav, der stilles til ham. Et givet læsefærdighedsniveau kan således være forbundet med store vanskeligheder i en bestemt uddannelse, hvor læsning er en vigtig kilde til læring, men ikke med nær så store vanskeligheder i en anden uddannelse, hvor det faglige stof i højere grad kan tilegnes på andre måder (jf. kapitel 6).

For personer, der overvejer at gå i gang med en uddannelse, kan det være nyttigt at kunne sammenligne læse- og skrivekravene i forskellige uddannelser. Især personer med svage læse- og skrivefærdigheder kan inden påbegyndelse af en uddannelse have interesse i at kunne få oplysninger om, hvorvidt en bestemt uddannelse kan forventes at være særligt krævende i forhold til læsning og skrivning. Dette giver disse personer bedre muligheder for enten at undgå en sådan uddannelse eller at sikre sig ekstra støtte, hvis de vælger at gå i gang. Oplysninger om de specifikke læse- og skrivekrav fremgår imidlertid normalt ikke direkte af de almindelige beskrivelser af de enkelte uddannelser.

Der kan på mange uddannelser gå deltagere, som vil få vanskeligheder med at opfylde kravene til læsning og skrivning, hvis der ikke tages særlige hensyn. Med henblik på at identificere sådanne personer kan det være hensigtsmæssigt, at de enkelte uddannelsesinstitutioner har redskaber til at foretage en screening af deltagerne, således at der tidligt i ud- 
dannelsesforløbet kan iværksættes særlige støtteforanstaltninger for dem, der befinder sig i risikozonen.

\subsubsection{Formål}

Projektet har til formål at bidrage til:

1. Udvikling af en metode til kvantificering af læse- og skrivekrav, således at kravene til deltagernes læse- og skrivefærdigheder bliver sammenlignelige på tværs af uddannelser.

2. Udvikling af en screeningsprocedure med henblik på identifikation af deltagere, der må formodes at have eller få problemer med at leve op til læse- og skrivekravene.

3. Udvikling af en model for illustrative beskrivelser af læse- og skrivekrav med henblik på en konkretisering af disse krav inden for de enkelte uddannelser.

\subsubsection{Metode}

\subsubsection{Kvantificering af læse- og skrivekrav}

Der gennemføres en undersøgelse med deltagere fra en række forskellige uddannelser. I undersøgelsen gennemfører disse deltagere udvalgte test af færdigheder i læseforståelse, afkodning og stavning. ${ }^{248}$ Undersøgelsesdeltagerne besvarer derudover spørgsmål om, hvorvidt de oplever vanskeligheder med at læse og skrive tekster i deres uddannelse, samt om, hvorvidt deres eventuelle læse-, stave- og skrivevanskeligheder har betydning for deres uddannelse. Deltageres objektivt målbare resultater på testene sammenholdes med deltagernes subjektive vurdering af læse- og skrivekravene i deres igangværende uddannelse. Det undersøges, hvordan de deltagere, der oplever vanskeligheder med læsning, stavning og skrivning, klarer sig på de anvendte test i sammenligning med de deltagere, der ikke oplever vanskeligheder. Der fastlægges en skillelinje baseret på de scores, som deltagerne med oplevede vanskeligheder opnår på de anvendte test. Disse skillelinjer kan forventes at variere mellem forskellige uddannelser, idet personer med færdigheder på samme niveau kan opleve vanskeligheder i nogle uddannelser, men ikke i andre, fordi der reelt stilles forskellige læse- og skrivekrav.

På basis af de fastlagte skillelinjer udarbejdes der en skala over læseog skrivekravene i de undersøgte uddannelser. På denne skala tildeles de undersøgte uddannelser point ud fra de fastlagte skillelinjer. I det følgende gives et tænkt og forenklet eksempel til illustration af princippet i ska-

\footnotetext{
${ }^{248}$ Der er til Styregruppen for Voksnes Læring (SVL) tidligere fremsendt en oversigt over eksisterende nordiske testmaterialer, som formodentlig vil kunne anvendes til formålet (afsnit $7.4 .5 \mathrm{i}$ rapport fremsendt til SVL februar 2007). Denne testoversigt indgår ikke i den offentliggjorte version af rapporten.
} 
laen: Undersøgelsen kunne fx vise, at en bestemt procentdel (fx $80 \%$ ) af deltagerne på uddannelse A med en bestemt testscore (fx 10 og derunder) oplever vanskeligheder med læsning og skrivning i uddannelsen. På uddannelse B viser undersøgelsen, at $80 \%$ af deltagerne med en testscore på 15 og derunder oplever vanskeligheder. Begge uddannelser tildeles et pointtal, fx 10 til uddannelse A og 15 til uddannelse B. Disse point signalerer, at læse- og skrivekravene på uddannelse B er højere end på uddannelse A, idet der på uddannelse B skal mindre alvorlige læse- og stavevanskeligheder til, førend deltagere føler sig generet af deres vanskeligheder.

\subsubsection{Udvikling af screeningsprocedure}

Foruden den omtalte skala over kravene udarbejdes der på grundlag af resultaterne af den ovenfor beskrevne undersøgelse en vejledning til en kommende screeningsprocedure i de undersøgte uddannelser. I screeningsproceduren indgår de test, som i undersøgelsen har vist sig at være bedst til at identificere deltagere, der oplever vanskeligheder med læsning og skrivning i deres uddannelse. Vejledningen udformes, så den kan bruges af de enkelte uddannelsesinstitutioner til tidligt i uddannelsesforløbet at identificere de deltagere, som kan forventes at blive generet af deres læseog stavevanskeligheder og derfor har brug for støtteforanstaltninger.

\subsubsection{Udvikling af model for illustrative beskrivelser af læse- og} skrivekrav

Den i afsnit 7.4.3.1 beskrevne kvantificering af læse- og skrivekravene er en relativt abstrakt måde at synliggøre kravene på. Som supplement til skalaen udarbejdes der illustrative beskrivelser af de specifikke læse- og skrivekrav på de udvalgte uddannelser med konkrete eksempler på læseog skriveopgaver. Beskrivelserne udformes, så de kan medvirke til at synliggøre betydningen af læsning og skrivning i den faglige sammenhæng for både undervisere og deltagere. Beskrivelserne kan fx indeholde:

- Eksempler på typiske læseopgaver, herunder illustrative uddrag af tekster, der skal læses på uddannelsen med angivelse af teksternes funktion i den faglige sammenhæng ( $\mathrm{fx}$ en instruktion, som skal læses omhyggeligt og følges nøje i forbindelse med værkstedsundervisning, eller grundbogsstof, som skal skimmes som forberedelse til teoriundervisning)

- Eksempler på typiske skriftlige opgaver/øvelser, der skal udarbejdes under uddannelsen (fx skrivning af rapport eller logbog), samt beskrivelse af, hvilke kriterier sådanne skriftlige produkter skal leve op til, eventuelt med eksempler på elementer af gode besvarelser. Der angives omfang og hyppighed af sådanne opgaver samt vilkårene for udarbejdelsen af dem (individuelt eller i grupper, med eller uden vejledning etc.). 


\subsubsection{Perspektiver}

Indledningsvis kan der i et enkelt nordisk land udvælges et mindre antal uddannelser, som kan indgå i det ovenfor beskrevne forsknings- og udviklingsarbejde. Hvis der høstes positive erfaringer med de nye metoder, vil metoderne i en justeret udgave kunne overføres til andre uddannelser, både i det pågældende land og i andre nordiske lande. 


\section{English preface}

This report has been drawn up as part of a project entitled 'Enhancing the literacy and IT skills of adults with limited formal education - a Nordic pilot study', commissioned and funded by the Nordic Council of Ministers' Steering Group for Adult Learning (SVL) and run in collaboration with literacy experts from Denmark, Norway, Sweden, Finland and Iceland.

Project management was provided by the undersigned (Anna Steenberg Gellert) in collaboration with Carsten Elbro of the Centre for Reading Research, University of Copenhagen. I have also been responsible for data gathering in Denmark; processing, editing and supplementing information gathered in the other Nordic countries; and preparing the collated report for the Nordic Council of Ministers. Karina Brunsgaard Bek and Kirstine Bagger Iversen of the Centre for Reading have provided practical assistance.

Egil Gabrielsen of the Reading Centre at the University of Stavanger was responsible for data gathering in Norway.

Ingrid Lavås of the Reading Project at the Mid Sweden University in Härnösand was responsible for the collection of data in Sweden. Andreas Skoglund assisted with literature research.

Rannveig Lund of the Rannveig Lund Reading Centre in Reykjavik was responsible for gathering data in Iceland, with the assistance of Thora Kristinsdóttir.

Emma Ojanen of the Niilo Mäki Institute at the University of Jyväskylä was responsible for gathering data in Finland.

The majority of the work on the preliminary project was done in 2006. The full report was circulated to the partners responsible for gathering data in the different countries for their inspection and comments in January 2007. Minor alterations have been made on the basis of their comments. As agreed with representatives of the Steering Group on Adult Learning (SVL) other minor alterations were subsequently made before publication of the report.

7 May 2007

Anna Steenberg Gellert 


\section{English summary}

This report has been drafted as part of a project entitled 'Enhancing the literacy and IT skills of adults with limited formal education - a Nordic pilot study'. It features the results of the survey, an introductory review of three areas and proposals for future projects.

\section{Introductory review of the extent of reading difficulties among adults with limited formal education in the Nordic countries}

Introductory review of the extent of reading difficulties among adults with limited formal education in the Nordic countries - with particular regard to difficulties in work and further education/training in trades and businesses that attract people with limited reading and writing skills.

Survey results are presented for each of the five Nordic countries Denmark, Norway, Sweden, Finland and Iceland - to illustrate the extent of reading and writing difficulties among adults with a limited formal education, with particular regard to work and further education/training (chapter 3). The surveys show unequivocally that there is generally a very strong correlation between literacy skills and educational achievement, and that the number of poor readers among the section of the adult population with a limited formal education easily exceeds the proportion in the adult population as a whole.

However, there were significant variations in the criteria used to define adequate reading skills in the surveys. It is therefore hardly surprising that the results reveal widely varying estimates of the numbers lacking adequate reading skills.

For example, a Danish survey found that some $21 \%$ of working adults with limited formal education face difficulties with everyday texts such as tabloid newspaper articles. The texts used in the study were hardly any more difficult than those people with little formal education might expect to encounter in their jobs and are, in all probability, easier than the types of materials they are likely to face on courses and in training situations in their field of work.

Several international reading surveys, including the OECD's (Second) International Adult Literacy Survey, are based on the premise that to be functionally literate, a person must be able to use reading as an instrument of personal development, e.g. in educational situations, where it is typically necessary to read relatively difficult texts. Correspondingly, 
most of the texts and tasks used in the OECD survey are considerably more difficult than those used in the Danish survey referred to above. The OECD survey's results indicate that between $50 \%$ and $75 \%$ of adults with a limited formal education in Denmark, Norway, Finland and Sweden have inadequate reading skills.

It is difficult to ascertain the extent of reading difficulties among adults with a limited formal education in their work situations, since the difficulties depend on the specific requirements of the job. Only a few Nordic studies focus on the reading requirements that the individuals in this group face in work and in further education and training. Although any estimate of the extent of the reading difficulties in the Nordic countries as a whole must therefore be subject to a great deal of uncertainty, on the basis of the Danish survey referred to above it is reasonable to assume a minimum level of around $20 \%$. The actual level may well be much higher, particularly if, like the OECD survey, this group of adults is also supposed to be capable of using reading as an element in personal development, i.e. in training and further education.

Since, as mentioned above, there have been relatively few Nordic studies of reading and writing requirements in work and further education situations, this report also includes results from outside the Nordic Region (see chapter 6). Workplace reading and writing requirements were studied by means of observation within the work situation, workers' own notes on the extent of their reading and writing, and interviews with managers and employees. The materials used in the workplaces have also been collected and analysed. Such studies show that adults whose work is practical in nature often only need to read for short periods at a time in order to carry out their work functions. Texts are typically used to look up specific information, while writing often takes the form of short sentences, individual words and codes. More extensive reading and writing may be needed to document the work carried out, participate in meetings and plan work processes, and for quality control. The importance of reading and writing varies from job to job, but written documentation in particular seems to have a steadily growing role, even in many jobs that do not require a high level of education.

Earlier studies of further education/training observed classroom situations, collected and analysed educational materials, and conducted interviews with teachers and participants to establish reading and writing requirements. These studies indicate that many practical training courses include some relatively difficult reading tasks. However, there are wide variations in the importance of reading for the acquisition of technical skills. On some courses, textbooks are an important source of technical knowledge, while on others such knowledge can to a certain extent be acquired through other means. Similarly, some practical training courses place great emphasis on the documentation of technical knowledge by 
means of written work, while writing does not play such an important role in other courses.

\section{Preliminary review of the nature and extent of provision for adults with inadequate literacy skills}

Data has been gathered in Denmark, Norway, Sweden, Finland and Iceland on the following types of provision:

- Work-based and leisure-time provision for adults with reading, spelling and writing difficulties, including dyslexia.

- Special help in educational contexts for people with reading, writing and spelling difficulties (with a particular focus on formal, practical courses designed to improve qualifications, or that target adults with a limited formal education).

- Specific provision for immigrants and others (with particular focus on support specifically designed to improve the reading, writing and IT skills of people whose native language differs from the majority language in their country of residence).

Within these areas, the report describes a range of different provisions in the various Nordic countries (chapter 4). It should be noted that, in many cases, no convincing documentation is available on the effectiveness of the initiatives described. It is therefore difficult to assess whether these various initiatives can usefully be replicated and implemented in other contexts.

\section{Preliminary review: Selected Nordic examples of literacy courses for adults}

For this review, a number of examples of initiatives aimed at reducing reading and writing difficulties among adults were described and analysed (chapter 5). One example is a Danish Preparatory Adult Education (FVU) project in reading, writing and written presentation for the staff of a local-authority care home and kitchen/service department. The second example is a reading and writing course offered by the Norwegian Workers' Educational Association (AOF). The third example is an individually tailored reading and writing course offered by the Swedish company Volvo.

All of these initiatives contain elements that could doubtless inspire other providers and teachers, but it should be pointed out that it is difficult to establish with certainty whether the initiatives described are in fact of greater benefit to adult participants than other initiatives, and therefore 
worthy of replication. This is partly due to the fact that the descriptions do not provide a reliable basis for assessing the methods. The surest way of establishing whether given methods of teaching reading and writing lead to better results than other methods would be to carry out specific evaluations of the outcomes.

\section{Proposals for future projects}

Based on the results of this review, the report concludes by setting out two proposals for future projects (chapter 7).

As mentioned above, there is a lack of studies of the effectiveness of various types of reading and writing courses. As a result, one proposal aims to study the effectiveness of a specially designed course based on the requirements participants face in their work or further education/training (project proposal I).

There is also a lack of guidelines on how reading and writing requirements might be systematically disclosed and made more visible, as well as tested methods of identifying people who have difficulty meeting these requirements. Therefore, a proposal is presented for a project that would contribute to the development of such guidelines and methods in educational situations (project proposal II). 


\section{Esipuhe}

Tämä raportti on laadittu osana projektia „Vähän koulutettujen aikuisten lukemis-, kirjoittamis- ja tietotekniikkataitojen parantaminen - pohjoismainen esitutkimus“. Projektin on käynnistänyt ja rahoittanut Pohjoismaiden ministerineuvoston alainen Aikuisten oppimisen johtoryhmä (SVL).

Projekti on toteutettu tanskalaisten, norjalaisten, ruotsalaisten, islantilaisten ja suomalaisten lukiasiantuntijoiden välisenä yhteistyönä.

Projektia ovat johtaneet Anna Steenberg Gellert ja Carsten Elbro Kööpenhaminan yliopiston lukutaidon tutkimuskeskuksesta. Steenberg Gellert on vastannut lisäksi tanskalaisten tietojen keruusta, neljästä muusta Pohjoismaasta kerättyjen tietojen muokkauksesta, toimittamisesta ja täydentämisestä sekä loppuraportin laatimisesta Pohjoismaiden ministerineuvostolle. Käytännön työssä ovat avustaneet lukutaidon tutkimuskeskuksen Karina Brunsgaard Bek ja Kirstine Bagger Iversen.

Norjaa koskevat tiedot on koonnut Egil Gabrielsen Stavangerin yliopiston lukikeskuksesta.

Ruotsia koskevat tiedot on koonnut Ingrid Lavås, joka työskentelee Härnösandissa toimivan Keski-Ruotsin yliopiston LäSa-projektissa. Kirjallisuuslähteiden etsimisessä on avustanut Andreas Skoglund.

Islantia koskevat tiedot on koonnut Rannveig Lund Reykjavikin akatemian lukikeskuksesta, ja häntä on avustanut Thora Kristinsdóttir.

Suomea koskevat tiedot on koonnut Emma Ojanen Jyväskylän yliopiston Niilo Mäki Instituutista.

Pääosa esiprojektiin liittyvästä työstä tehtiin vuonna 2006. Loppuraportti lähetettiin tammikuun 2007 lopussa tarkistettavaksi ja kommentoitavaksi yhteistyökumppaneille, jotka olivat vastanneet eri Pohjoismaita koskevien tietojen keruusta. Heidän kommenttiensa perusteella raporttiin tehtiin pienehköjä muutoksia. Aikuisten oppimisen johtoryhmän (SVL) edustajien kanssa tehdyn sopimuksen mukaisesti raporttiin on lisäksi tehty muutamia muita pienehköjä muutoksia ennen sen julkistamista.

7. toukokuuta 2007

Anna Steenberg Gellert 



\section{Tiivistelmä raportin sisällöstä}

Tämä raportti on laadittu osana projektia „Vähän koulutettujen aikuisten lukemis-, kirjoittamis- ja tietotekniikkataitojen parantaminen - pohjoismainen esitutkimus“. Raportti sisältää tutkimuksen tulokset ja antaa alustavan selvityksen näiltä kolmelta alueelta sekä ehdotuksia tuleviksi projekteiksi.

\section{Introductory review of the extent of reading difficulties among adults with limited formal education in the Nordic countries}

Alustava selvitys vähän koulutettujen pohjoismaisten aikuisten lukivaikeuksista, jotka liittyvät varsinkin työskentelyyn ja jatkokoulutukseen aloilla ja ammateissa, joihin hakeutuu yleensä rajalliset lukemis- ja kirjoittamistaidot omaavia henkilöitä

Kustakin viidestä Pohjoismaasta, eli Tanskasta, Norjasta, Ruotsista, Suomesta ja Islannista, raportoidaan tutkimuksista, joiden tulokset valottavat vähän koulutettujen aikuisten lukivaikeuksien laajuutta varsinkin työ- ja koulutusnäkökulmasta (ks. luku 3). Tutkimukset osoittavat selvästi, että lukutaidon ja koulutustason välillä on yleensä hyvin vahva yhteys ja että vähän koulutettujen keskuudessa on huomattavasti enemmän huonoja lukijoita muihin aikuisiin verrattuna.

Eri tutkimuksissa on kuitenkin noudatettu hyvin erilaisia kriteerejä sen suhteen, millaisista lukemistehtävistä henkilön tuli selviytyä, jotta hänellä voitiin sanoa olevan riittävä lukutaito. Tämän vuoksi ei olekaan yllättävää, että tutkimukset antavat hyvin erilaisia tietoja siitä, kuinka suurella osalla väestöstä on riittämätön lukutaito.

Esimerkiksi erään tanskalaisen tutkimuksen mukaan noin 21 \%:lla vähän koulutetuista työssäkäyvistä on vaikeuksia lukea täysin arkipäiväisiä tekstejä, kuten aamulehden artikkelia. Tähän tutkimukseen sisältyneet tekstit olivat tuskin vaikeampia kuin aineisto, jota vähän koulutetut kohtaavat työssään, ja ne olivat hyvin todennäköisesti helpompia kuin heidän oman alansa kurssi- ja koulutustekstit.

Useiden kansainvälisten lukutaitotutkimusten, kuten OECD:n (Second) International Adult Literacy Surveyn, mukaan funktionaalisen lukutaidon edellytyksenä on se, että henkilö voi käyttää lukemista oman henkisen kehityksensä välineenä esimerkiksi koulutustilanteissa, joissa luetaan yleensä varsin vaikeita tekstejä. Tämän vuoksi pääosa OECDtutkimuksen teksteistä ja tehtävistä oli huomattavasti vaikeampia kuin 
edellä mainitussa tanskalaistutkimuksessa. OECD-tutkimuksen mukaan n. 50-75 \%:lla vähän koulutetuista tanskalaisista, norjalaisista, suomalaisista ja ruotsalaisista aikuisista on riittämätön lukutaito.

Vähän koulutettujen henkilöiden työhön liittyvien lukemisvaikeuksien yleisyyttä on vaikea määritellä, koska mahdolliset vaikeudet riippuvat työssä kohdattavien tekstien vaativuudesta. Pohjoismaissa on tutkittu vasta hyvin vähän sitä, millaisia lukutaitovaatimuksia vähän koulutettuihin aikuisiin kohdistuu työ- ja koulutusyhteyksissä. Tiedot näiden ihmisten lukemisvaikeuksien laajuudesta ovat siten väistämättä hyvin epävarmoja, mutta edellä mainitun tanskalaistutkimuksen pohjalta lienee perusteltua todeta, että vaikeuksia on vähintään noin 20 \%:lla aikuisista. Todellinen luku voi hyvin olla huomattavasti suurempi, varsinkin jos vaatimuksena on OECD-tutkimuksen tapaan se, että vähän koulutettujen tulee voida käyttää lukemista henkilökohtaisen kehityksensä välineenä esimerkiksi kurssi- ja koulutusyhteyksissä.

Koska Pohjoismaissa on tehty varsin vähän tutkimuksia työhön ja koulutukseen liittyvistä luku- ja kirjoitustaitovaatimuksista, raporttiin on sisällytetty tuloksia myös Pohjoismaiden ulkopuolella toteutetuista tutkimuksista (ks. luku 6). Työelämän luku- ja kirjoitustaitovaatimuksia on tutkittu muun muassa tarkkailemalla työskentelytilanteita, analysoimalla työntekijöiden omia muistiinpanoja heidän lukemis- ja kirjoittamistehtäviensä laajuudesta ja luonteesta sekä haastattelemalla esimiehiä ja työntekijöitä. Lisäksi on kerätty ja analysoitu aineistoja, joita tutkituilla työpaikoilla käytettiin. Nämä tutkimukset osoittavat, että käytännönläheistä työtä tekevät aikuiset lukevat yleensä vain vähän aikaa kerrallaan suorittaessaan työtehtäviään. Tekstejä käytetään yleensä erilaisten tietojen tarkistamiseen, kun taas kirjoittaminen rajoittuu lyhyisiin lauseisiin, yksittäisiin sanoihin ja koodeihin. Laajemmat luku- ja kirjoitustehtävät voivat liittyä esimerkiksi tehdyn työn dokumentointiin, kokouksiin osallistumiseen, työprosessien suunnitteluun ja laadunvarmistukseen. Lukemisen ja kirjoittamisen merkitys vaihtelee huomattavasti työstä toiseen, mutta kirjallista dokumentointia tunnutaan vaadittavan yhä enemmän myös useissa sellaisissa ammateissa, jotka eivät edellytä korkeaa koulutustasoa.

Koulutustilanteista on tehty aiemmin tutkimuksia, joissa on selvitetty luku- ja kirjoitustaitovaatimuksia esimerkiksi tarkkailemalla opetustilanteita, keräämällä ja analysoimalla opetukseen sisältynyttä aineistoa sekä haastattelemalla opettajia ja osallistujia. Tutkimukset antavat viitteitä siitä, että moniin käytännönläheisiin koulutusohjelmiin sisältyy jonkin verran myös varsin raskaita tekstejä. Toisaalta koulutusohjelmien välillä on suuria eroja sen suhteen, miten tärkeää lukeminen on ammatillisen tiedon omaksumisen kannalta. Joissakin koulutusohjelmissa ammatillisten tekstien lukeminen on tärkeä tiedonlähde, kun taas toisissa koulutusohjelmissa tämä tieto voidaan tiettyyn rajaan asti omaksua muulla tavoin. Vastaavasti joissakin käytännönläheisissä koulutusohjelmissa painotetaan 
vahvasti ammatillisen tiedon dokumentointia kirjoitustehtävien avulla, kun taas toisissa koulutusohjelmissa ei niinkään painoteta kirjoittamista.

\section{Alustava selvitys lukivaikeuksisiin aikuisiin kohdistuvien palveluiden ja toimenpiteiden sisällöstä ja laajuudesta}

Tanskassa, Norjassa, Ruotsissa, Suomessa ja Islannissa on kerätty tietoja seuraavanlaisista palveluista ja toimenpiteistä:

- lukivaikeuksisille aikuisille suunnatut työ- ja vapaa-ajanpalvelut ja toimenpiteet

- lukivaikeuksisten henkilöiden koulutukseen liittyvät tukipalvelut (varsinkin palvelut, jotka liittyvät ammattipätevyyden antaviin koulutuksiin, jotka ovat käytännönläheisiä ja/tai vähän koulutetuille aikuisille suunnattuja)

- siirtolaisille ja vastaaville ryhmille tarjottavat erityispalvelut (varsinkin palvelut, jotka nimenomaisesti tähtäävät muuta kuin kyseisen maan pääkieltä puhuvien henkilöiden luki- ja tietotekniikkataitojen parantamiseen).

Raportissa kerrotaan useista Pohjoismaissa toteutetuista palveluista ja toimenpiteistä, jotka liittyvät näihin alueisiin (ks. luku 4). Samalla todetaan kuitenkin, että kuvattujen palveluiden tehosta ei useinkaan ole vakuuttavaa näyttöä. Tämän vuoksi onkin vaikeaa arvioida, kannattaako vastaavia toimenpiteitä toteuttaa muissa yhteyksissä.

\section{Alustava selvitys: esimerkkejä pohjoismaisista aikuisten lukikursseista}

Esiprojektin yhteydessä kerättiin tietoja muutamista toimenpiteistä, joilla on pyritty vähentämään aikuisten lukivaikeuksia (ks. luku 5). Ensimmäisenä esimerkkinä on lukikoulutus, joka järjestettiin erään tanskalaiskunnan päivähoito- sekä keittiö- ja palveluhenkilöstölle osana valmistavaa aikuiskoulutusta (FVU). Toisena esimerkkinä on Norjan Työväen sivistysliiton (Arbeidernes Opplysningsforbund, AOF) järjestämä lukikurssi. Kolmantena esimerkkinä ovat Volvon Ruotsissa tarjoamat yksilölliset lukiopetuspalvelut.

Näitä kolmea esimerkkiä kuvaillaan ja arvioidaan raportissa. Kaikkiin raportoituihin toimenpiteisiin sisältyy osatekijöitä, jotka todennäköisesti voivat antaa virikkeitä muille palveluntarjoajille ja opettajille. Tutkijat huomauttavat kuitenkin, että on vaikeaa tietää varmasti, ovatko kuvatut toimenpiteet todellakin parempia kuin monet muut vastaavat toimenpiteet ja siten kopioimisen arvoisia. Tämä johtuu muun muassa siitä, että kuva- 
usten perusteella ei ole luotettavia perusteita arvioida, hyödyttävätkö käytetyt menetelmät aikuisia osallistujia enemmät kuin jotkin muut menetelmät. Jos halutaan tietää, johtavatko tietyt lukiopetusmenetelmät parempiin tuloksiin kuin toiset, varminta tietoa saadaan toteuttamalla varsinaisia tehokkuustutkimuksia.

\section{Ehdotuksia tuleviksi projekteiksi}

Esiprojektin tulosten perusteella raportissa tehdään lopuksi kaksi ehdotusta tuleviksi projekteiksi (ks. luku 7).

Kuten edellä on mainittu, erityyppisten lukiopetustoimenpiteiden tehokuutta ei ole tutkittu tarpeeksi. Tämän vuoksi raportissa tehdäänkin ehdotus projektista, jossa tutkittaisiin räätälöityjen lukiopetustoimenpiteiden tehokkuutta niiden vaatimusten pohjalta, joita osallistujat kohtaavat työssään tai koulutuksessaan (projektiehdotus I).

Meiltä puuttuu yhä ohjeita siitä, miten luku- ja kirjoitustaitovaatimukset voidaan selvittää ja määritellä järjestelmällisesti. Lisäksi tarvitaan hyväksi havaittuja menetelmiä niiden henkilöiden tunnistamiseksi, joilla on vaikeuksia täyttää vaatimuksia. Tämän vuoksi raportissa tehdään ehdotus projektista, joka auttaisi kehittämään näitä ohjeita ja menetelmiä koulutustarkoituksiin (projektiehdotus II). 


\section{Referencer $^{249}$}

${ }^{249}$ Finske titler er oversat til engelsk af Emma Ojanen og indsat i kantede parenteser. Islandske titler er oversat til dansk eller engelsk af Rannveig Lund og ligeledes indsat i kantede parenteser. 



\section{Samlet referenceliste}

Alm, J. (1996). The dyslexia project at the employability institute of Uppsala. Vtu, 7. Uppsala: Arbetsmarknadsstyrelsen. (http://www.tuffa.nu/rapporter\%5CVtu_ 1996_7.pdf)

Alm, J. (2004). Dyslexia: Relevance of Concepts, Validity of Measurements, and Cognitive Functions. Uppsala: Acta Universitatis Upsaliensis.

(http://www.diva-portal.org/diva/ getDocument?urn_nbn_se_uu_diva4123-1_fulltext.pdf)

Andersen, A.M, Egelund, N., Jensen, T.P., Krone, M., Lindenskov, L. \& Mejding, J. (2001). Forventninger og fcerdigheder danske unge i en international sammenligning. København: Amternes og Kommunernes Forskningsinstitut.

Arendal, E. (2005). Pc-læsningsprojekt for ordblinde. Hjcelpemiddelinstituttets $\mathrm{Ny}$ hedsbrev (september 2005).

(http://www.hmi.dk/index.asp?search=P C-læsning\&id=772\#711)

Arendal, E. (2006). Hjcelpemidler til mennesker med ordblindhed. Århus:

Hjælpemiddelinstituttet.

Arendt, J.N., Rosholm, M. \& Jensen, T.P. (2005). The Importance of Literacy for Employment and Unemployment Duration. København: Amternes og Kommunernes Forskningsinstitut.

(http://www.akf.dk/udgivelser/ workingpaper/2005/pdf/10_2005 literacy employment.pdf/)

Arnardóttir, E. \& Kristmundsson, G.B. (2005). Um niðurstöður lestrarrannsóknar. ["Om resultater fra læseforskning“]. Gátt - the annual review. Sími: Fræðslumiðstöð Atvinnulífsins.

Arnardóttir, E., Kristmundsson, G.B. \& Björnsdóttir, A. (2006). Lœesi fullorðinna, lesiðni og ritvenjur. [Literacy among adults, time used into reading and reading habits]. Reykjavík: Rannsóknarstofnun Kennaraháskóla Íslands.

Arnbak, E. (1999). Faglig leesning i AMU

- en undersøgelse af sammenhrengen mellem AMU-deltageres funktionelle lcesefcerdighed og deres faglige lcesning. København: Arbejdsmarkedsstyrelsen.

Arnbak, E. (2004). When are poor reading skills a threat to educational achievement? Reading and Writing, An Interdisciplinary Journal, 17(5), 459-482.
Arnbak, E. (2005). Udsigt til indsigt? Kvalitet i læseundervisning for voksne. In: Charlotte Ringsmose og Kirsten Baltzer (Eds.). Specialpcedagogik ad nye veje: et festskrift til Niels Egelund i anledning af hans 60 års dag (pp. 231238). København: Danmarks Pædagogiske Universitet.

Arnbak, E. \& Borstrøm, I. (2001). Hverdagsstavning - et materiale til afdcekning af voksnes staveferdigheder. En pilotafprøvning. København: Undervisningsministeriet.

(http://us.uvm.dk/voksen/fvu/hverdagsst avning.pdf)

Arnbak, E. \& Borstrøm, I. (2002). Hverdagsstavning for voksne. Et materiale til afdcekning af voksnes stavefcerdigheder. København: Undervisningsministeriet. (http://us.uvm.dk/ voksen/fvu/Vejledninger/documents/ Trinplacering-laes-vejl-juni04bilag3.pdf)

Arnbak, E. \& Borstrøm, I. (2002). Hverdagsskrivning for voksne. Et materiale til afdcekning af voksnes skriftlige fremstilling. København: Undervisningsministeriet. (http://us.uvm.dk/ voksen/fvu/Vejledninger/documents/ Trinplacering-laes-vejl-juni04bilag4.pdf)

Arnbak, E. \& Borstrøm, I. (2004). FVUdeltageres bevidsthed om og udbytte af lase-, stave- og skriveundervisning - en afprøvning af to undervisningsmaterialer. København: Undervisningsministeriet. (http://us.uvm.dk/voksen/fvu/ documents/afrpoevning_undervisnings materialer.pdf)

Arnbak, E. \& Elbro, C. (1999). Læsning, lesekurser og uddannelse. Om unge og voksnes funktionelle lcesefcrdighed i uddannelse og på læesekurser vurderet med et nyt materiale. København: Center for Læseforskning, Københavns Universitet.

Arnbak, E. \& Elbro, C. (2000). Lcesetekster for gymnasium, hf mv. København: Undervisningsministeriet og Center for Læseforskning.

Arnbak, E. \& Elbro, C. (2001). Lesetekster for unge og voksne. København: Dansk Psykologisk Forlag.

Askov, E. N. (1993). Approaches to assessment in workplace literacy pro- 
grams: meeting the needs of all clients. Journal of Reading, 36, 550-555.

Askov, E. N. (2000). Workplace literacy: Evaluation of three model programs. Adult Basic Education, 10(2), 100-108.

Askov, E. N. \& Gordon, E. E. (1999). The brave new world of workforce education. New Directions for Adult and Continuing Education, vol. 83, 59-68.

Barton, P. (2000). What jobs require: Literacy, Education, and Training 19402006. Policy Information Report. Princeton NY: Educational Testing Service.

Bekkevold, K., Yin, H., Servan, K.T., Jørgensen P.M. \& Anderssen, A.F. (2005). Grundleggende ferdigheter $i$ norsk arbeidsliv. Resultater fra Voxbarometeret høsten 2005. Oslo: Vox.

Belfiore, M. E. (2004). Reading Work. Literacies in the New Workplace. Mahwah: New Jersey: Lawrence Erlbaum Associates.

Bengtsson, S., Levén, A. \& Gustafson, S. (2006). Studier och delaktighet: En analys av några studenter med funktionshinder vid Linköpings universitet. Rapport till Strategigruppen för lika villkor. Linköping: Linköpings universitet. (www.liu.se/likavillkor/)

Bernhoft, A. (2006). Ordblinde får undervisning på arbejdet. LVUfagbladet 8, 10-11.

Blöndal, P. (2006). Drög að náminu lögð á kaffistofunni. Starfstengt íslenskunám á vegum Alpjóðahússins. ["The study is organized in the coffee room. The Intercultural Centers language study in connection to the jobs"]. Morgunblaðið, 24. september, 20-21.

Boesen, O. \& Krohn-Rasmussen, J. (2006). Ordblinde efteruddanner sig som aldrig før. Nyt om ordblindhed, nr. 46. (http://www.dvo.dk/index. php?id=164).

Bratsberg, B., Hægeland, T. \& Raaum, O. (2006). Lese- og tallforståelse, utdanning og arbeidsmarkedssuksess. Stavanger: Universitetet i Stavanger, Lesesenteret.

Carter, J., Kjertmann, K., Klewe, L. \& Larsen, I.B. (2004). Forberedende voksenundervisning (FVU) - en undersøgelse af erfaringerne med FVU. København: Danmarks Pædagogiske Universitet.

Chang, K.L. (1983). An Investigation of the Curricular and Occupational Read- ing Demands of the Plumbing Trade.

M.A. Thesis. University of Calgary.

Claesson, S. \& Dahlgren, H. (2002). Att studera i fängelse. Utvärdering av klientutbildning inom kriminalvården. Göteborgs universitet: Institutionen för pedagogik och didaktik (www.kvv.se)

Clausen, J.K. \& Haven, D. (2005). Voksne ordblinde - en antologi. Dansk Psykologisk Forlag.

Danmarks Evalueringsinstitut (2005).

Forberedende voksenundervisning.

København: Danmarks Evalueringsinstitut.

(http://217.61.44.102/Admin/Public/Do wnlo-

$\underline{\text { ad.aspx?file=Files/Filer/Rapporter } \% 202}$ 004/Forberedende\%20voksenundervisni ng/FVU-rapport.pdf)

Danmarks Evalueringsinstitut (2006).

Forberedende voksenundervisning. Årsrapport 2006. København: Danmarks Evalueringsinstitut.

Dansk Videnscenter for Ordblindhed (2006). Rapport om afprøvning af visitationstest til brug i ordblindeundervisning for voksne. København: Undervisningsministeriet. (http://us.uvm.dk/voksen/ fvu/documents/endelig rapport.doc)

Davis, R.D. (2006). Den begavede dyslektiker. København: Klim. (Oversættelse af: Davis, R.D. (1997). The gift of dyslexia. New York: Perigee Books).

Diekhoff, G. M. (1988). An appraisal of adult literacy programs. Journal of Reading, vol. 31(7), 624-630.

Eggertsdóttir, R. og Jónsdóttir, P.B. (2001). Aðstoð við nemendur með leshömlun. Könnun í framhaldsskólum og háskólum veturinn 2000-2001. [,Hjælp til ordblinde elever. Undersögelse i videregående skole og universitet, 2000-2001“]. Akureyri: Universitetet i Akureyri.

Elbro, C., Møller, S. \& Nielsen, E. M. (1991). Danskernes laseferdigheder. En undersøgelse af 18-67-åriges lesning af dagligdags tekster. København: Projekt Læsning og Undervisningsministeriet.

Engell, L. V. (2003). Derfor FVU på arbejdspladsen! København: Undervisningsministeriet. (http://us.uvm.dk/ voksen/fvu/fvu-cases/alle_artikler.pdf).

Engesbak, H. \& Finbak, L. (2005). Mye vil ha mer - om deltakelse i etter- og videreutdanning. Samfunnsspeilet 3. (http://www.ssb.no/ssp/) 
Engesbak, H., Haugerud, V., Røstad, S. \& Stubbe, T.A. (2003). Men hvor skal vi henvende oss? Oslo: Vox.

Engesbak, H. \& Stubbe, T.A. (2005). I videregående som voksen. Voksnes rett til grunnskole og videregående opplaring. Oslo: Vox.

Eriksen, A. H. (1999). Turbo på de ordblinde. Fagbladet, vol. 31, pp. 14-15.

Fermischek, V. \& Åhlund, G. (2004). Dyslexiprojektet. Hjälpmedel - Anpassning - Skräddarsydda lösningar. Stockholm: Arbetsmarknadsstyrelsen.

Finbak, L. \& Engesbak, H. (2006). Å delta eller ikke delta. Om voksnes deltakelse $i$ etter- og videreutdanning. Stavanger: Universitetet i Stavanger, Lesesenteret.

Fræðslumiðstöð atvinnulífsins. [Arbejdslivets undervisningscenter]. (2004). Aftur í nám - námskrá. [Tilbage til uddannelse - studieplan]. Sími: Fræðslumiðstöð atvinnulífsins.

Föhrer, U. \& Magnusson, E. (2003). Läsa och skriva fast man inte kan. Kompenserande hjälpmedel vid läs- och skrivsvårigheter. Lund: Studentlitteratur.

Gabrielsen, E. (2000). Slik leser voksne i Norge. En kartlegging av leseferdigheten i aldersgruppen 16-65 år. Stavanger: Universitetet i Stavanger, Lesesenteret.

Gabrielsen, E. (2002). Lese for livet. Lesekompetansen i den norske voksenbefolkningen sett i lys af visjonen om en enhetsskole. Bergen: Universitetet i Bergen, Institut for Samfunnspsykologi.

Gabrielsen, E. (2005). Hvor godt må vi kunne lese for å fungere i dagens samfunn? Samfunnsspeilet 2.

(http://www.ssb.no/ssp/)

Gabrielsen, E. (2005a). Kan leseferdigheter måles og sammenlignes? Samfunnsspeilet 2, 39-44.

Gabrielsen, E. (2005b). Hvor godt må vi kunne lese for å fungere i dagens samfunn? Samfunnsspeilet 2, 45-49.

Gabrielsen, E. (2005c). Er vi egentlig så dårlige til å regne? Samfunnsspeilet 3 , 15-20.

Gabrielsen, E. (2006). Slik kan voksnes leseferdigheter måles. Om teorigrunnlaget for IALS og ALL. Monografiserien ALL nr. 6. Stavanger: Universitetet i Stavanger, Lesesenteret.

Gabrielsen, E. (2006). Opplysninger fra Norge. Stavanger: Senter for leseforsking. (Upubliceret rapport udarbejdet i forbindelse med nordisk forprojekt om voksne kortuddannedes læsning).
Gabrielsen, E., Haslund, J. \& Lagerstrøm, B.O. (2005). Lese- og mestringskompetanse i den norske voksenbefolkningen. Resultater fra „Adult Literacy and Life Skills“ (ALL). Stavanger: Universitetet i Stavanger, Lesesenteret.

Gabrielsen, E. og Lagerstrøm, B.O. (2005). Mange innvandrere er dårlige til å lese norsk. Samfunnsspeilet 2, 2-10.

Gabrielsen, E., \& Myrberg, M. (2001). Adult education for at-risk groups. In: Tuijnman, A. \& Hellström, Z. (eds.). Curious Minds. Nordic Adult Education Compared. (pp. 105-115). København: Nordisk Ministerråd.

Gabrielsen, E. og Ritland, A. (2000). Tre av ti leser for dårlig. Samfunnsspeilet 4, 36-43.

Gellert, A. (1999). Hvordan kan man forudsige forskelle i elevers læseforståelse af faglige uddannelsestekster? En undersøgelse af en elevgruppe på den pædagogiske grunduddannelse. Psykologisk Pcedagogisk Rådgivning, 36(5-6), 395-418.

Gerrevall, P. \& Jenner, H. (2001). Kommunikativ pedagogik och särskilda ungdomshem. Stockholm: Statens institutionsstyrelse (SiS).

Grønborg, A. Madsen, P. Nielsen, B. \& Sørensen, H. (1994). Incidensundersøgelse. En undersøgelse af liese- og stavestandpunktet blandt elever på teknisk Skole og AMU-skolen i Odense foretaget i foråret 1994. Odense: Fyns Amts Taleog Høreinstitut.

Guðmundsdóttir, H. (2004). Annual report of grown ups informal education. Gátt. Sími: Fræðslumiðstöð Atvinnulífsins.

Gunnilstam, O \& Mårtens, M. (2002).

Lexia 4 - Handbook. Sköndal: Stiftelsen Stora Sköndal.

Gustavsson, A-L.E. (1997). Att läsa - ett behov, ett krav, en nödvändighet. En analys av den första internationellt jämförande studien av vuxnas förmåga att förstå och använda skriftlig information. International Adult Literacy Survey. Linköpings universitet: Institutionen för pedagogik och psykologi.

Gustavsson, A-L.E. (2002). Att hantera läskrav i arbetet. Om industriarbetare med läs- och skrivsvårigheter.

Linköpings Universitet: Department of Behavioural Sciences.

Gustavsson, A-L.E. (2005). Jag fixar det oftast. Hur industriarbetare hanterar 
läs- och skrivkrav i arbetet. Lund: Studentlitteratur.

Haapasalo, S. Lund \& Halonen (2006). Luki-lukkoja avaamassa 2002-2005. LUKKI-hankkeen loppuraportti. [,Opening dyslexia-locks 2002-2005. The final report of LUKKI-project“]. Turku: Turun kristillisen opiston säätiö. (http://www.tk-opisto.fi/liitteet/tko00010424-2.pdf)

Haapasalo, S. \& Salomäki, J. (2000). On kuin kivi olisi vierähtänyt sydämeltä. Kokemuksia aikuisten erilaisten oppijoiden ryhmäkuntoutuksesta. [„It's like rolling a stone down from one's heart. Experiences from group rehabilitation of adult diverse learners"]. Helsinki: Kuntoutussäätiön tutkimuksia 64.

Halonen, M. \& Peltoniemi, A. (2003). Äänteellistä ja kielellistä valmiutta kehittäviä harjoituksia. Maahanmuuttajien erityiset kielelliset oppimisvaikeudet. [,Assignments for practising phonetic and linguistic capacity. Specific lingual learning difficulties of immigrants"] (MERKO). Turku:Turun kristillisen opiston säätiö.

Handels-, Transport- og Serviceerhvervenes Arbejdsgiverforening \& Institut for Konjunktur-Analyse (2004). Det rummelige Arbejdsmarked. Tiltrcekke, fastholde, udvikle. København: Handels-, Transport- og Serviceerhvervenes Arbejdsgiverforening.

Hansen, G. (2003). Vellykket Voksenopplæring i Vestfold. Bris 2, 54-57. (http://www.nav.no/1073749975.cms)

Harboe, A.H. (2005). Læse- og skrivekrav i erhvervsuddannelserne. Lœsepcedagogen 5, 20-23.

Harboe, A.H. (2004). Rapport om Lceseprojektet $i$ ungdomsuddannelserne i skoleåret 2003-2004. Århus: Uddannelsesrådet i Århus Amt.

Haugerud, V., Røstad, S. \& Stubbe, T.A. (2005). Intensjoner og realiteter. Fylkeskommunenes håndtering av voksnes rett til videregående opplcring. Oslo: Vox.

Haugerud, V., Røstad, S. \& Stubbe, T.A. (2006). Grunnskoleopplaring for voksne. Oslo: Vox.

Haven, D. (1998). Gode og dårlige læsere efter 9. klasse. Anden del af en efterundersøgelse. Psykologisk Padagogisk Rådgivning, 35(5/6), 454-472.

Helén, E. (2001). Dyslexic adults' nonverbal visual-auditory and auditory-visual associative learning. Jyväskylä: Univer- sity of Jyväskylä, Department of Psychology. (Unpublished Master's thesis).

HERO/Herosak (2003). SF-SOL. Södra Finlands Skriv- och Läsprojekt 20012002. Helsinki: HERO/Herosak.

Hjelmquist, E. \& Euler von, C. (2002). Dyslexia and literacy. London: Whurr.

Holders, B., Petersen, D.K., Borstrøm, I. \& Elbro, C. (1996). Undervisning af voksne ordblinde. En undersøgelse af undervisningseffekt og lcererkvalifikationer i ordblindeundervisningen i AOF. København: Forlaget Skolepsykologi.

Holopainen, L., Kairaluoma, L., Nevala, J., Ahonen, T., \& Aro, M. (2004). Lukivaikeuksien seulontamenetelmä nuorille ja aikuisille. [„,Dyslexia screening tool for youth and adults“]. Jyväskylä: University of Jyväskylä, Niilo Mäki Institute.

Hull, G. (1993). Critical literacy and beyond: Lessons learned for students and workers in a vocational program and on the job. Anthropology and Education Quarterly, vol. 24(4), 373-396.

Hull, G. (1997). Changing Work, Changing Workers. Critical perspectives on Language, Literacy, and Skills. New York: State University of New York.

Hull, G. (1998). The changing world of work. Journal of Adolescent Literacy, 42(1), 26-29.

Hull, G. (2000). Critical literacy at work. Journal of Adolescent Literacy, 43(7), 648-652.

Hull, G., Jury, M., Ziv, O. \& Katz, M. (1996). Changing work, changing literacy: A study of skill requirements and development in a traditional and restructured workplace (Final Report). Berkeley, CA: National Center for Research in Vocational Education, Center for the Study of Writing and Literacy.

Hvenekilde, A., Alver, V., Bergander, E., Lahaug, V. \& Midttun, K. (1996). Alfa og Omega. Om alfabetiseringsundervisning for voksne fra språklige minoriteter. Oslo: Novus Forlag.

Hätinen, P. (2001). Lukivaikeus aikuisiällä. [„,Dyslexia in adulthood“]. Joensuu: University of Joensuu, Department of Education. (Unpublished Master's thesis).

Høien, T. \& Lundberg, I. (1997). Dyslexi. Fra teori till praktis. Oslo: Ad Notam Gyldendal. 
Høien, T. \& Tønnesen, G. (2004). Ordkjedetesten. Stavanger: Stiftelsen Dysleksiforsking.

Hölkki, H. \& Salonen, L. (2006). Onko lukiossa lukivaikeutta? Opiskelijoiden kokemuksia lukemisen vaikeudesta. [,Is there dyslexia in upper general secondary school? Students experiences from difficulty in reading"]. Joensuu: University of Joensuu, Department of Special Education. (Unpublished Master's thesis).

Jacobson, C. (2001). LäsKedjor. Stockholm: Assessio (tidligere Psykologiförlaget).

Jensen, J., Lindgren, M., Andersson, K., Ingvar, D.H. \& Levander, S. (2000). Cognitive Intervention in Unemployed Individuals with Reading and Writing Disabilities. Applied Neuropsychology, 7(4), 223-236.

Jensen, T.P. (2002). Literacy-kompetence. I: Uddannelsesstyrelsen: Nøglekompetencer - forskerbidrag til Det Nationale Kompetenceregnskab. København: Undervisningsministeriet.

(http://pub.uvm.dk/2002/nkr/dokumentat ionsrapport/)

Jensen, T. P. (2006). Læese- og skrivesvages deltagelse i voksen- og efteruddannelse. København: AKF Forlaget. (http://www.akf.dk/udgivelser/2006/pdf/ laese_skrivesvages_veu.pdf)

Jensen, T. P., Andersen, A.R., Brown, R., \& Hansen, E.B. (2006). Lese-stavesvages brug af VEU. København: AKF Forlaget. (http://www.akf.dk/udgivelser/ 2006/pdf/laese_stave_svages_veu.pdf)

Jensen, T.P., Andersen, A. \& Halgreen, T. (2001). Lasefcerdigheder og deltagelse $i$ samfundslivet. København: Amternes og Kommunernes Forskningsinstitut \& Specialarbejderforbundet i Danmark (SID).

Jensen, T.P. \& Holm, A. (2000). Danskernes lase-regne-fcerdigheder - $i$ et internationalt lys. København: AKF Forlaget.

Jensen, T.P. \& Holm, A. (2000). Lcesekurser for voksne, udbytte og tilrettelceggelse. København: AKF Forlaget.

Jensen, V. B., Erdmann, O. \& Gravesen (1995). Svage leesere på HTX. København: Københavns Tekniske Gymnasium.

Johansson, M. (1999). MG-kedjor. Frösön: MG Läs- och Skrivkonsult AB.
Johansson, M. (2004). LS - Reviderad Klassdiagnoser i läsning och skrivning för högstadiet och

gymnasiet. Stockholm: Assessio (tidligere Psykologiförlaget).

Jokinen, J.M. (1994). Aikuisopiskelijoiden luetun ymmärtäminen. [,Reading comprehension of adult students"]. Jyväskylä: University of Jyväskylä, Department of Special Education. (Unpublished Master's thesis).

Jónasdóttir S. (2005). Námsáhugi fólks með litla formlega menntun.[,„Interesse for uddannelse hos voksne med kort formel uddannelse"]. Ritgerð til meistaraprófs við Kennaraháskóla Íslands. [MA-afhandling]. Reykjavík: Kennaraháskóli Íslands.

Jónasson, J.T. \& Blöndal, K.S. (2002). Progress and completion of students in upper secondary school in Iceland in light of their residence. A study of the cohort born in 1975. Reykjavík: University of Iceland, Social Science Institute.

Järpsten, B. (2002). DLS för skolår 7-9 och år 1 i gymnasiet. Stockholm: Assessio (tidligere Psykologiförlaget).

Kairaluoma, L., Nevala, J., Ahonen, T., \& Aro, M. (2004). Lukivaikeuksien seulontamenetelmä nuorille ja aikuisille. [,Dyslexia screening tool for youth and adults“]. Jyväskylä: University of Jyväskylä, Niilo Mäki Institute.

Kakkuri, I. (1993). Aikuisten lukemis- ja kirjoittamisongelmat ammatillisessa aikuiskoulutuksessa, työvoimakoulutuksessa ja kansanopistossa. [„Adults’ reading and writing difficulties in vocational adult education, manpower education and folk high school“]. Jyväskylä: University of Jyväskylä, Department of Special Education.

Karlsson, A. (2003). Writing and texts in construction. A case study of the daily reading and writing practices of construction workers. Stockholm: Stockholms Universitet, Institutionen för nordiska språk. (http://www.nordiska.su.se/ skriftbruk/byggrapport.pdf)

Karlsson, A. (2003). The cab is his office. A study of the reading and writing, texts and literacy environments of a truck driver. Stockholm: Stockholms Universitet, Institutionen för nordiska språk. (http://www.nordiska.su.se/skriftbruk/tra nsportrapport.pdf)

Karlsson, A. (2004). How to build a house from reading a drawing - Professional 
and popular mediations of construction. Visual Communication 3 (3), 251-279.

Karlsson, A. (2005). Goods, services and the role of written discourse. In: Gunnarsson, B. (ed.). Communication in the Workplace. (pp. 91-104) Uppsala: Uppsala University.

Karlsson, A. (2005). Variation as text politics. Five store texts and their roles in the new work order. In: Berge, K.L. \& Maagerø, E. (eds.). Semiotics from the North. Nordic approaches to systemic functional linguistics.(pp. 85-98) Oslo: Novus.

Karlsson, A. (2006). Reading to be independent, writing to be controlled? Roles and literacies offered to workers in modern organisations. Stockholm: Stockholms Universitet, Institutionen för nordiska språk. (http://www.nordiska.su.se/ skriftbruk/Karlsson_Reading_to_be_ Independent.doc)

Kennemyr, I. Ridderstad, P. \& Tyreus, S. (2002). Datorn - kompensatoriskt hjälpmedel och stöd vid inlärning för vuxna elever med läs- och skrivsvårigheter. Stockholm: Folkbildingsrådet. (http://www.resurs.folkbildning.net/dow nload/515/loftadalendatorn

hjalpmede.pdf)

Ketolainen, H. (2003). Elämänkumppanina lukivaikeus. Elämänkertahaastatteluihin perustuva kolmen lukivaikeuksisen aikuisen elämismaailmaa kuvaava tutkimus. [„,Dyslexia as a partner in life. Biography based study of life of three dyslexic adults"]. Rovaniemi: University of Lapland, Faculty of Education. (Unpublished Master's thesis).

Kivi, T.(2004). LATU maahanmuuttajilleprojekti. Raportti 1.10.2000-31.12.2003. [,,Track for immigrants. Report 1.10.2000-31.12.2003“]. Lahti: Tiedonpuu ry.

Kokkila, H. (2003). Elinikäiseksi oppijaksi aikuisiällä? Vailla toisen asteen tutkintoa olevien 30-54 vuotiaiden osallistuminen aikuiskoulutukseen ja käsitykset koulutuksen tarpeesta. [„Becoming a lifelong learner in adult age? Participating to adult education among 30-54 year old people without a secondary level qualification“]. Joensuu: University of Joensuu, Department of Sociology.

Kolbeinsson, G. \& Ásbjörnsson F. (1994). Lestu betur [„„Læs bedre“]. Reykjavík: IĐNÚ.
Korhonen, T (1995). The Persistence of Rapid Naming Problems in Children with Reading Disabilities: A Nine-Year Follow-up. Journal of Learning Disabilities, 28(4), 232-239.

Kjær, S., Lind, H. \& Villadsen, S. (1999). Faglige teksters lasbarhed - en effektundersøgelse på Novo Nordisk. København: Københavns Universitet. (Bachelorprojekt).

Knudsen, L. (undervejs). Faglige tekstgenrer i 8. klasse. En effektundersøgelse af undervisning i generekendskab. København: Center for Læseforskning, Københavns Universitet.

Kujala, T, Karma, K. Ceponiene, R., Belitz, S., Turkkila, P., Tervaniemi, M. \& Näätänen, R. (2001). Plastic neural changes and reading improvement caused by audiovisual training in reading-impaired children. Proceedings of the National Academy of Science, vol. 98.

Kukkonen, P., Kurki, A. \& Soukka, A. (2003). Mikä ihmeen näyttö? Tietoa nuorten näytöistä opiskelijalle, työpaikkaohjaajalle sekä opettajalle. [,What is skills demonstration? Information on youth's skills demonstrations for students, work place supervisors and teachers"]. Oulainen: Oulaisten terveydenhuolto-oppilaitos. (http://db3.edu.fi/esr/ tiedostot/OUTH\%20opas.pdf)

Kuntaliitto (2004). Kromosomeista kaksoiskonsonantteihin: Lukibussin matkakirja. [„,From chromosomes to double consonants. Travelling log of dyslexiabus"]. Helsinki: Kuntaliitto.

Københavns Kommune (2005). Spids pennen - en evaluering af hotlinefunktionen. København: Undervisningsministeriet. (http://us.uvm.dk/voksen/fvu/ documents/hotlinefunktionen.pdf)

Lahtinen, M., Lankinen T., Penttilä, A., \& Sulonen, A. (2004). Koulutuksen lainsäädäntö käytännössä. [,,Legislation of education in practice“]. Juva: Tietosanoma, WSOY.

Larson, A. (2005). Psykosociale forhold $i$ arbejdslivet og kortuddannede/ufaglertes interesse for uddannelse. (Ph.d-afhandling). København: Danmarks Pædagogiske Universitet.

Lau, J., Holst, C., Brøcker, A. \& Klausen, A.B. (1995). Nytter det noget? - om den kompenserende specialundervisning for lase- og stavehandicappede i Århus 
Amt. Århus: Århus Amt \& Danmarks Pædagogiske Institut.

Lau, J. \& Sommer, M. (1999). Voksne leser på arbejdspladsen. København: Danmarks Pædagogiske Institut.

Lausch, B., Jakobsen, K. \& MunchHansen (1999). Jeg lieste en hel bog og nu tør jeg også skrive - faglig leesning og skrivning på erhvervsskoler. København: Undervisningsministeriet.

Lavikainen, H. (2005). Itseraportoitujen koulunkäynti- ja oppimisvaikeuksien yleisyys ja yhteydet lapsuuden ja nuoren aikuisuuden elämäntilanteisiin ja koettuun terveyteen. [„„Prevalence of selfreported school and learning difficulties and connections to lifesituations and experience of health in childhood and young adulthood“]. Jyväskylä: University of Jyväskylä, Department of health. (Unpublished Master's thesis).

Lavås, I. (2006). Svenska data i förundersökning av kortutbildade med läs- och skrivsvårigheter. Härnösand: Mittuniversitetet. (Upubliceret rapport udarbejdet i forbindelse med nordisk forprojekt om voksne kortuddannedes læsning).

Lehtola, R. \& Lehto J. (2000). Assessing dyslexia in Finnish high-school students: a pilot study. European Journal of Special Needs Education, vol. 15(3), 255-263.

Leinonen, S. (2001). Heterogeneity in adult dyslexic readers: Relating processing skills to the speed and accuracy of oral text reading. Reading and Writing, vol. 14(3-4), 265-296.

Letrud, K.H. (2004). Fra sjenanse til verdighet. A legge til rette for lese- og skriveutvikling i egen bedrift. Oslo: Vox. (http://www.vox.no/upload/Nedlastingss enter/sjenanseogverdighet.pdf )

Lindell, C.G. (1998). Dyslexi i arbetslivet : ett informationsmaterial om vuxnas läsoch skrivsvårigheter. Stockholm: Arbetarskyddsnämnden.

Lindström, Y. (2001). Vad har motiverat vuxna personer med läs- och skrivsvårigheter att börja studera? Luleå: Luleå Tekniska Universitet.

Linnakylä, P. (1991). Quality of Vocational Literacy: how Finnish vocational school students learn from text. Scandinavian Journal of Educational Research, vol. 53(4), 253-268.

Linnakylä, P., Malin, A., Blomqvist, I. \& Julkunen, S. (2000). Lukutaito työssä ja arjessa: Aikuisten kansainvälinen luku- taitotutkimus Suomessa. [„,Literacy in work and life: adults international literacy research in Finland“]. Jyväskylä: University of Jyväskylä, Koulutuksen tutkimuslaitos.

Lund, A. (2004). LUKKI-projekti. In: Hämäläinen Riitta, Riitta Salin ja Airi Valkama (eds.).

Kromosomeista kaksoiskonsonantteihin, lukibussin matkakirja [„,From chromosomes to doubleconsonants: the journey story of Lukibussi“]. Helsinki: Suomen kuntaliitto.

Lund, J. \& Pedersen, L. V. (2006). Effekt af FVU \& Anbefalinger til Uddannelsesaktører på FVU-området. København: Mercuri Urval.

(http://us.uvm.dk/voksen/fvu/documents/ kvu_rapport.pdf)

Lund, K., Bertelsen, E. \& Sørensen, M.S. (2006). Muligheder og barrierer - en undersøgelse af overgangen mellem sprogcentre og erhvervsrettede uddannelser. København: Ministeriet for Flygtninge, Indvandrere og Integration. (http://www.nyidanmark.dk/NR/rdonlyre s/01C5917D-4222-49C4-9BA28BEB58800ECA/0/Muligheder barriere r.pdf)

Lund, R. (2006). Innsamling av nasjonale opplysninger i Island i forbindelse med nordisk

førprosjekt om kortutdannede voksnes lesning. Reykjavik: Lestrarsetur Rannveigar Lund.

Lund, R. og Lárusdóttir, A. (2004). GRP14 Handbók. Greinandi ritmálspróf fyrir 14. ára

nemendur. Reykjavík, höfundar.

Lundetræ, K. \& Gabrielsen, E. (2006). På lik linje? Om voksnes mestring av matematikk i dagliglivet. Stavanger: Universitetet i Stavanger, Lesesenteret.

Lundgren, T. (2001). IT-satsningar på området läs- och skrivsvårigheter/dyslexi. Observatoriet för IT, lärande, kunskap och kompetens, Stockholm: ITKommissionen.

(http://www.itkommissionen.se/dynamas ter/file_archive/020124/7f479597f0c95c d6fcf17815d0397d92/42_2001\%20ITsatsningar\%20p\%E5\%20omr\%E5det\% 20l\%E4s-\%20och\%20skrivsv\% E5righeter_dyslexi.pdf)

Lundgren, T. (2003). Vad alla bör veta om läs- och skrivsvårigheter. Stockholm: Förbundet Funktionshindrade med läsoch skrivsvårigheter. 
LukSitko 1/2005, 2/2005, 1/2006.

Malmodin, H. (2002). Volvo satsar på lästräning - 100 tog ny chans att lära sig läsa. Dagens Nyheter (ekonomidelen), 28/9-2002.

Mejding, J. (2004). PISA 2003 - Danske unge $i$ en international sammenligning. København: Danmarks Pædagogiske Universitets Forlag.

Michailakis, D. (2002). Studie av en arbetsplatsanpassning med IT-baserade hjälpmedel för funktionshindrade personer. Uppsala: Institutet för arbetsmarknadspolitisk utvärdering (IFAU).

Mikulecky, L. (1982). The relationship between school preparation and workplace actuality. Reading Research Quarterly, 17(3), 400-419.

Mikulecky, L. (1985). Literacy Task Analysis: Defining and Measuring Occupational Literacy Demands. Paper presented at the National Adult Educational Research Association. Chicago, IL.

Mikulecky, L. (2000). Developing and Teaching in Workplace Literacy Programs. Paper presented at the Annual Meeting of the International Reading Association. Indianapolis.

Mikulecky, L., Albers, P. \& Peers, M. (1994). Literacy Transfer: a Review of the Literature. Indiana University: National Center on Adult Literacy.

Mikulecky, L. \& Diehl, W. (1980). Job Literacy: A Study of Literacy Demands, Attitudes, and Strategies in a CrossSection of Occupations. Indiana University, Bloomington.

Mikulecky, L. \& Drew, R. (1991). Basic literacy skills in the workplace. In: R. Barr (ed.): Handbook of Reading Research II. New York: Longman.

Mikulecky, L. \& Ehlinger, J. (1986). The Influence of Metacognitive Aspects of Literacy on Job Performance of Electronics Technicians. Journal of Reading Behaviour, vol. 28(1), 41-62.

Mikulecky, L. \& Lloyd, P. (1993). The impact of workplace literacy programs: a new model for evaluating the impact of workplace literacy programs. Indiana University: National Center on Adult Literacy.

(http://ncal.literacy.upenn.edu/cgiin/search.pl?int_topic_id=23;int_type_id $=0$;submit=Find $\% 20$ Materials;int_match es $=32 ;$ int_current_page $=4$ )
Mikulecky, L. \& Lloyd, P. (1996). Evaluation of Workplace Literacy Programs: a Profile of Effective Instructional Practices. Philadelphia: National Center on Adult Literacy.

(http://ncal.literacy.upenn.edu/cgibin/search.pl?int_topic_id=23;int_type_i $\mathrm{d}=0$; submit=Find\%20Materials;int matc hes=32;int_current_page $=3$ )

Mikulecky, L., Lloyd, P., Horwitz, L., Masker, S. \& Siemantel, P. (1996). A review of recent workplace literacy programs and a projection of future challenges. Philadelphia: National Center on Adult Literacy. Philadelphia: National Center on Adult Literacy.

(http://ncal.literacy.upenn.edu/cgibin/search.pl?int_topic_id=23;int_type_i $\mathrm{d}=0$; submit=Find\%20Materials;int_matc hes=32;int_current_page $=3$ )

Mikulecky, L. \& Winchester, D. (1983). Job Literacy and Job Performance among nurses at varying employment levels. Adult Education Quarterly, vol. 34 (1).

Munch-Hansen, T. \& Albæk, K. (1994). Faglces - et analyse- og udviklingsprojekt om leesesvage i arbejdsmarkedsuddannelserne. København: Arbejdsmarkedsstyrelsen.

Myrberg, M. (2001). Att förebygga och möta läs- och skrivsvårigheter: En översikt av aktuell forskning om läs- och skrivsvårigheter. Stockholm: Skolverket. Myrberg, M. (2003). Att skapa konsensus om skolans insatser för att motverka läsoch skrivsvårigheter. Stockholm: Lärarhögskolan i Stockholm, Institutionen för Individ Omvärld och Lärande. (http://www.lhs.se/iol/publikationer)

Myrberg, M. (2001). Att öppna språkgränser - klyftor och broar i vuxna invandrares läs- och skrivutveckling - En studie baserad på International Adult Literacy Survey och forskning om invandrares läs- och skrivinlärning på sittandraspråk. Stockholm: Lärarhögskolan i Stockholm. (http://www.skolverket.se/ publikationer?id=1086)

Myrberg, M., Gustavsson, A-L.E. \& Ericsson, Å. (2000). International Adult Literacy Survey: Invandrares läs-, skriv- och räkneförmåga. Linköpings Universitet, Läspedagogiska Institutet EMIR. (http://skolnet.skolverket.se/pdf/ials.pdf) Møller, S. \& Elbro, C. (1992). Ufaglcertes lasning. En undersøgelse af ufaglcerte arbejderes lesning set $i$ relation til an- 
dre voksnes lasning. København: Specialarbejderforbundet i Danmark (SID).

Møller, S. \& Nielsen, R. (1986). Svage lasere eller dårlige tekster? En undersøgelse af tekster og lcesere på kurser for specialarbejdere. Pædagogiske forskningsrapporter nr. 35. København: Læsepædagogen.

Mørch, A. \& Solheim, I. (2005). Integrert e-læring i bedriften. Pedagogikk, teknologi, organisasjon. Oslo: Unipub Forlag.

NAV NONITE - Nordnorsk IKT-senter (2006). Nordisk informations DVD om teknologisk lcese- og skrivestøtte i arbejdslivet. Bodø: NAV NONITE Nordnorsk IKT-senter.

Nevala, J., Kairaluoma, L., Ahonen, T., Aro, M., \& Holopainen, L. (2006). Lukemis- ja kirjoittamistaitojen yksilötestistö nuorille ja aikuisille. [,,Test package for individual assessment of reading and writing skills for youth and adults“]. Jyväskylä: University of Jyväskylä, Niilo Mäki Institute.

Nielsen, A. S. (1999). Læse- og stavetrcning for voksne i arbejde. København: Danmarks Pædagogiske Institut.

Nielsen, C. (2005). Mellan fakticitet och projekt. Läs- och skrivsvårigheter och strävan att övervinna dem. Göteborg: Uddevalla, Acta Universitatis Gothoburgensis, Högskolan Trollhättan, Institutionen för individ och samhälle.

Nielsen, G.Ø., Johansen, J., Nielsen, J.C. \& Nissen, T. (1996). Leeseundervisning af voksne indvandrere - et udviklingsarbejde. København: Danmarks Pædagogiske Institut.

Nielsen, I. \& Petersen, D. K. (1992). DIAVOK. En diagnostisk lase- og stavetest. København: AOF-Danmark.

NIRAS-konsulenterne (2006). Evaluering af kompetenceudviklingsprojekt „Skriftlig kommunikation “ for medarbejdere $i$ Greve Kommunes Hjemmepleje. Slutevaluering. Roskilde: Roskilde Amt.

Norback, J.S. (1995). Job Literacy: A Framework for Categorizing Skills and Assessing Complexity. Princeton, New Jersey: Center for Skills Enchancement. Norback, J.S. (1998). Literacy Skills Analysis for Job Training. University of Pennsylvania: National Center on Adult Literacy.

Norback, J.S., Rosenfeld, M. \& Wilson, S.T. (1994). Job Literacy Analysis: a Practical Methodology for Use in Identifying Job-related Literacy Skills. Prince- ton, New Jersey: Center for Skills Enchancement.

Nyen, T. (2005). Livslang læring i norsk arbeidsliv II. Resultater fra Lærevilkårsmonitoren 2005. Oslo: Forskningsstiftelsen Fafo.

Nyen, T. (2006). Hvis jobben krever det. En analyse av sammenhengene mellom krav til basisferdigheter, faktiske basisferdigheter og deltakelse i laringsaktiviteter i norsk arbeidsliv. Stavanger: Universitetet i Stavanger, Lesesenteret.

OECD (1997). Reading skills for the knowledge society, further results from the International Adult Reading Survey. Paris: OECD.

OECD (2000). Literacy in the Information Age: Final Report of the International Adult Literacy Survey. Paris: OECD.

OECD (2001). Knowledge and skills for life. First results from PISA 2000. Paris: OECD.

OECD (2005). Promoting Adult Learning. Paris: OECD.

Ohlsson, L.I.M. (2000). Rapport angående Läs- och skriv/dyslexiundervisning/ på kriminalvårdsanstalten i Malmö. Lund: Lunds Universitet, Pedagogiska institutionen.

Ojanen, E. (2006). Finnish data for the Nordic pre-project. Jyväskylä: University of Jyväskylä, Niilo Mäki Institute. (Upubliceret rapport udarbejdet i forbindelse med nordisk forprojekt om voksne kortuddannedes læsning).

Opetushallitus [National Board of Education]. (2006). Luku- ja kirjoitustaidottomien aikuisten maahanmuuttajien koulutus. Suositus opetussuunnitelmaksi. [,Education of illiterate adult immigrants. Recommendation for curriculum“] Helsinki: Opetushallitus.

Opetusministeriö [Ministry of Education]. (1992). Opetusministeriön työryhmien muistioita. Promemorior av undervisningsministeriets arbetsgrupper 41. Aikuisten lukemis- ja kirjoittamisvaikeuksia selvittäneen työryhmän muistio. [,„Notation of appointed team of adult learning and writing difficulties"]. Helsinki: Opetusministeriö.

Opetusministeriö [Ministry of Education]. (1999). Opetusministeriön työryhmien muistioita. Promemorior av undervisningsministeriets arbetsgrupper 6 . Luki-työryhmän muistio. [,Notation of appointed dyslexia team"]. Helsinki: Opetusministeriö. 
Óskarsdóttir, G. G. (2000). The Transfer from School to Work. Studies on the Relationship between School and Employment. Reykjavík: University of Iceland, Social Science Institute. University of Iceland Press.

Pajukoski, S. \& Koskinen, S. (2003). Erilaiset oppijat näytöissä, osaraportti II. Opetus, ohjaus ja näytön toteutus ammatillisessa peruskoulutuksessa. [,Diverse learners in skills demonstrations, project report II. Teaching, instruction and organising skills demonstration in vocational secondary school“]. Helsinki: Helsingin seudun erilaiset oppijat ry (HERO).

(http://www.saunalahti.fi/mik4/nayttoprojekti/tiedostot/2.valiraportti.doc)

Pajukoski, S. \& Rinne, E. (2002). Erilaiset oppijat näytöissä, osaraportti I. Erilaisen oppijan tunnistaminen sekä tuki-ja ohjaustoimet ammatillisessa peruskoulutuksessa. [„Diverse learners in skills demonstrations, project report I. Recognising diverse learner and support and counselling methods in vocational secondary school"]. Helsinki: Helsingin seudun erilaiset oppijat ry (HERO).

(http://www.saunalahti.fi/mik4/nayttoprojekti/tiedostot/raportti_1.doc)

Pajukoski, S., Tuomi, A. \& Koskinen, S. (2004). NÄYTTÖ - mahdollisuus erilaiselle oppijalle. Opas ammatillisen peruskoulutuksen opettajalle, työpaikkaohjaajalle ja opiskelijalle. [,Demonstration, a possibility for a diverse learner. Guidebook for teachers of vocational schools, supervisor in the work place and the students"]. Helsinki: Helsingin seudun erilaiset oppijat ry (HERO). (http://www.saunalahti.fi/mik4/nayttoprojekti/tiedostot/hero.pdf)

Pedersen, L.B.T. \& Løvengreen, K. (2006). Brancherettet FVU - et idékatalog om information og tilrettelaggelse af FVU på virksomheder. København: FVU-team Storkøbenhavn. (http://www.fvu-team.dk/pdf/ opsoegerkatalog samlet.pdf)

Perin, D. (1994). Carving a Path from Job Materials to a Workplace Basic Skills Curriculum. Adult Learning, 5(4), 15-17.

Perin, D. (1994). Relationships between Student Variables and Pre-Post Gain in a Workplace Literacy Program. New York: Center for Advanced Study in Education, The Graduate School and
University Center of the City University of New York.

Perin, D. (1994). Workplace Literacy for Psychiatric Health Care Workers: Final Performance Report. New York: Center for Advanced Study in Education, The Graduate School and University Center of the City University of New York.

Perin, D. (1997). Workplace Literacy Assessment. Dyslexia, 3, 190-200.

Philippi, J.W. (1988). Matching literacy to job training: Some applications from military programs. Journal of Reading, 31(7), 658-666.

Philippi, J.W. (1991). Literacy at work. The workbook for program developers. New York: Simon \& Schuster Workplace Resources.

Philippi, J.W. (1998). Essential Skills for the Care Team. External Evaluation. Final Report. The Eddy/Northeast Health and Rockefeller College, University at Albany.

Pousette, S., Berns, T. \& Wirstad, J. (1999). AMS - Stava Rätt. Stockholm: Arbetsmarknadsservice.

Pöyhönen, A. (1997). Lukemisvaikeus ammatillisessa koulutuksessa aikuisopiskelijan kokemuksena. [„Adult students experience of reading difficulty in vocational school"]. Turku: University of Turku, Department of Education. (Unpublished Master's thesis).

Rikstrygdeverket, Senter for IKThjelpemidler \& Nonite (2005). Arbeidstakere og arbeidssøkere med lese/skrivevansker - 2002-2004. Projektrapport. Bodø: NAV NONITE Nordnorsk IKT-senter.

Roos, E.E. (2004). Räcker det att ta bort trösklarna eller kan man snubbla ändå? Om studiesituationen för studerande med funktionshinder under Kunskapslyftet. Malmö: Malmö högskola.

Roos, E.E. (2006). Aldrig för sent. Verksam pedagogik för vuxna med läs- och skrivsvårigheter. Växjö: Växjö Universitet, Institutionen för Pedagogik. (http://www.sit.se/download/PDF/Dysle xi/Aldrig_för_sent,_slutvers.pdf)

Rush, R.T., Moe, A.J. \& Storlie, R.L. (1986). Occupational Literacy Education. Newark, DE: International Reading Association.

Savikuja, T. (2005). Aikalisä-projekti ja erilaisen oppimisen polut 2002-2004. [,Aikalisä project and paths of diverse learning 2002-2004“]. Helsinki: HERO. 
Skolverket (1996). Grunden för fortsatt lärande - En internationell jämförande studie av vuxnas förmåga att förstå och använda tryckt och skriven information. Stockholm: Skolverket.

Solheim, I. (2006). Strategi- og samarbeidslcring: utprøvning og spredning. Evaluering av samarbeidsprosjekt rettet mot lceringsstrategier og leseforståelse $i$ tilknytning til arbeidslivet. Oslo: Norsk Regnesentral.

Solheim, I. \& Ytrehus, S. (2005). Lese- og skriveopplæring som nytter. Etterundersøkelse av deltakere på AOFs lese- og skrivekurs. Oslo: Forskningsstiftelsen Fafo.

Sheenan-Holt, J.K. \& Smith, C. (2000). Does basic skills education affect adults' literacy proficiencies and reading practices? Reading Research Quarterly, 35(2), 226-243.

Stefánsdóttir, H.B. (2006). Eins og fræ sem er sett í nýja mold. [As a seed which is sowed in a new earth]. Eins og fólk er flest. [„,Like other people“]. The Intercultural Centre Magazine. Alpjóðahúsið ehf .3. nummer, sept.

Sticht, T. (1997). Assessing foundation skills for work. In: H.F. O’ Neil (ed.). Workforce readiness: Competencies and Assessment. (pp. 255-292). Mahwah, NJ: Lawrence Erlbaum Associates.

Sticht, T.G. (2001). The International Adult Literacy Survey: How well does it represent the literacy abilities of adults? The Canadian Journal for the Study of Adult Education, 15, 19-36.

Suhonen, H. (1999). Ä̈̈neen lukeminen on kaikista pahin. Kokeellinen tapauskertomus lukivaikeuksisen aikuisen opetuksesta. [,Reading aloud is worst of all. Experimental case story on teaching of dyslexic adult"]. Jyväskylä: University of Jyväskylä, Department of Special Education. (Unpublished Master's thesis).

Swanson, H.L. (1999). Reading Research for Students with LD: A Meta-Analysis of Intervention Outcomes. Journal of Learning Disabilities, 32(6), 504-532.

Taube, K. (2002). Läsinlärning och självförtroende: psykologiska teorier, empiriska undersökningar och pedagogiska konsekvenser. Stockholm: Prisma.

Taylor, M.C. (2000). Transfer of learning in workplace literacy programs. Adult Basic Education, 10(1), 3-20.
Tilaéus, T. (2005). Lukemisen ja kirjoittamisen vaikeudet toisen asteen ammatillisessa koulutuksessa. [„,Reading and writing difficulties in vocational secondary level school“]. Jyväskylä: University of Jyväskylä, Department of Special Education. (Unpublished Master's thesis).

Tjernström, M. (2004). Vuxna dyslektikers informationsbeteende -En undersökning av hur sex personer med dyslexi hanterar informationsproblem. Borås: Biblioteks- och Informationsvetenskap /Bibliotekshögskolan. (www.hb.se/bhs/ slutversioner/2004/04-92.pdf)

Tord, S. (1984). Vore kul att kunna skriva - en rapport om läs- och skrivsvårigheter bland vuxna. Stockholm: Utbildningsradion.

Trepartsudvalget (2006). Livslang opkvalificering og uddannelse for alle på arbejdsmarkedet. Bind 1: Den fremtidige voksen- og efteruddannelsesindsats. København: Finansministeriet.

(http://www.fm.dk/1024/visPublikatione sForside.asp?artikelID=8112)

Tønseth, C., Finbak, L., Rønning, W.M. \& Sølvberg, A.M. (2006). Digitale skillelinjer. Voksnes bruk av PC og Internett. Stavanger: Universitetet i Stavanger, Lesesenteret.

Undervisningsministeriet (2002). Undervisningsvejledning. Forberedende voksenundervisning (FVU) i lasning, stavning og skriftlig fremstilling. København: Undervisningsministeriet. (http://us.uvm.dk/voksen/fvu/undervisni ngsvejl_laesning.pdf)

Undervisningsministeriet (2004). Fakta om FVU. København: Undervisningsministeriet. (http://us.uvm.dk/voksen/ fvu/fvu-cases/fakta_om_fvu.htm? menuid=350525)

Undervisningsministeriet (2004). Konferencerapport fra FVU-lcererkonferencen 2004. Nye veje for voksne i arbejde. København: Undervisningsministeriet. (http://us.uvm.dk/voksen/fvu/informatio n_generel/konferencerapport_fvuny.pdf)

Undervisningsministeriet (2004). Vejledning til trinplacering (2. udgave). Afdcekning af FVU-deltageres erfaringer, fcerdigheder og strategier i lcesning, stavning og skriftlig fremstilling. København: Undervisningsministeriet. (http://us.uvm.dk/voksen/fvu/Vejledning er/documents/Trinplacering-laes-vejljuni04-vejl.pdf) 
Undervisningsministeriet (2005). Det Nationale Kompetenceregnskab - Hovedrapport. København: Undervisningsministeriet.

(http://pub.uvm.dk/2005/NKRrapport/)

Undervisningsministeriet (2006). Fakta om forsøg med etablering af ord-og regnevcerksteder for deltagere i erhvervsrettet voksen- og efteruddannelse på erhvervsrettede uddannelsesinstitutioner. København: Undervisningsministeriet. (http://us.uvm.dk/amu/fou/ tup/documents/Ord-ogregnevaerksted erforkortudd.udmeldingstekst_000.pdf)

Undervisningsministeriet (2006). Foreløbig vejledning om visitation til ordblindeundervisning for voksne. Indledende samtale, obligatorisk test og visitation. København: Undervisningsministeriet.

Utbult, M. (2003). När orden står i vägen: om läs- och skrivsvårigheter för fackligt aktiva inom LO-förbunden. Stockholm: Landsorganisationen i Sverige.

Utdannings- og forskningsdepartementet (2005). Lcreplan i norsk og sammfunnskunnskap for voksne innvandrere. Oslo: Utdanningsdirektoratet. (http://www.utdanningsdirektoratet.no/u pload/larerplaner/norsk samfunnskunns kap_voksne_innvandrere.pdf)

\section{Danske referencer}

Andersen, A.M, Egelund, N., Jensen, T.P., Krone, M., Lindenskov, L. \& Mejding, J. (2001). Forventninger og ferdigheder danske unge i en international sammenligning. København: Amternes og Kommunernes Forskningsinstitut.

Arendal (2005). Pc-læsningsprojekt for ordblinde. Hjcelpemiddelinstituttets $\mathrm{Ny}$ hedsbrev (september 2005).

(http://www.hmi.dk/index.asp?search=P C-læsning\&id=772\#711)

Arendal, E. (2006). Hjwelpemidler til mennesker med ordblindhed. Århus:

Hjælpemiddelinstituttet.

Arendt, J.N., Rosholm, M. \& Jensen, T.P. (2005). The Importance of Literacy for Employment and Unemployment Duration. København: Amternes og Kommunernes Forskningsinstitut.

(http://www.akf.dk/udgivelser/ workingpaper/2005/pdf/10_2005_ literacy_employment.pdf/)

Arnbak, E. (1999). Faglig leesning i AMU - en undersøgelse af sammenhrengen
Viig, M. (2006). Info-centre for ordblinde. Status set i forhold til overførsel af midler fra 2005 til 2006. Haderslev: VUC Sønderjylland.

Vox (2005). INOVI. Ikt i norskopplaringen for voksne innvandrere. Oslo: Vox.

Vox (2005). Sentrale begreber i norskplanen. In: Metodisk Vejledning. Lcreplan i norsk og sammfunnskunnskap for voksne innvandrere. (pp. 26-31). Oslo: Vox.

Vox (2006). BASIS! Voksnes lcering 2006 - tilstand, utfordringer og anbefalinger. Oslo: Vox

Witting, M. (1996). Studenters arbete med att övervinna läs- och skrivsvårigheter: process- och resultatredovisning av ett projekt vid Linköpings universitet. Solna: Ekelund.

Witting, M. (1996). Vuxnas kamp för att erövra språket i skrift: om att övervinna läs- och skrivsvårigheter och få tillgång till det skrivna ordet. Solna: Ekelund.

Wolff, U. (2005). Characteristics and varieties of poor readers. Göteborg : Acta Universitatis Gothoburgensis.

Ödman, M. (1997). Även en vuxen kan ha svårt att läsa och skriva: en skrift om dyslexi. Stockholm: Johansson \& Skyttmo.

mellem AMU-deltageres funktionelle lcesefcerdighed og deres faglige liesning. København: Arbejdsmarkedsstyrelsen.

Arnbak, E. (2004). When are poor reading skills a threat to educational achievement? Reading and Writing: An interdisciplinary Journal, 17(5), 459-482.

Arnbak, E. (2005). Udsigt til indsigt? Kvalitet i læseundervisning for voksne. In: Charlotte Ringsmose og Kirsten Baltzer (eds.). Specialpcedagogik ad nye veje: et festskrift til Niels Egelund i anledning af hans 60 års dag (pp. 231-238). København: Danmarks Pædagogiske Universitet.

Arnbak, E. \& Borstrøm, I. (2001). Hverdagsstavning - et materiale til afdcekning af voksnes stavefærdigheder. En pilotafprøvning. København: Undervisningsministeriet. (http://us.uvm.dk/ voksen/fvu/hverdagsstavning.pdf) Arnbak, E. \& Borstrøm, I. (2002). Hverdagsstavning for voksne. Et materiale til afdcekning af voksnes stavefcerdigheder. 
København: Undervisningsministeriet. (http://us.uvm.dk/voksen/fvu/Vejledning er/documents/Trinplacering-laes-vejljuni04-bilag3.pdf)

Arnbak, E. \& Borstrøm, I. (2002). Hverdagsskrivning for voksne. Et materiale til afdcekning af voksnes skriftlige fremstilling. København: Undervisningsministeriet.

(http://us.uvm.dk/voksen/fvu/Vejledninger /documents/Trinplacering-laes-vejljuni04-bilag4.pdf)

Arnbak, E. \& Borstrøm, I. (2004). FVUdeltageres bevidsthed om og udbytte af lase-, stave- og skriveundervisning - en afprøvning af to undervisningsmaterialer. København: Undervisningsministeriet. (http://us.uvm.dk/voksen/fvu/ documents/afrpoevning_undervisnings materialer.pdf)

Arnbak, E. \& Elbro, C. (1999). Leesning, lesekurser og uddannelse. Om unge og voksnes funktionelle lasefcerdighed i uddannelse og på lcesekurser vurderet med et nyt materiale. København: Center for Læseforskning, Københavns Universitet.

Arnbak, E. \& Elbro, C. (2001). Lasetekster for unge og voksne. København: Dansk Psykologisk Forlag.

Bernhoft, A. (2006). Ordblinde får undervisning på arbejdet. LVUfagbladet 8, 10-11.

Boesen, O. \& Krohn-Rasmussen, J. (2006). Ordblinde efteruddanner sig som aldrig før. Nyt om ordblindhed, nr. 46. (http://www.dvo.dk/index.php?id=164).

Carter, J., Kjertmann, K., Klewe, L. \& Larsen, I.B. (2004). Forberedende voksenundervisning (FVU) - en undersøgelse af erfaringerne med FVU. København: Danmarks Pædagogiske Universitet.

Clausen, J.K. \& Haven, D. (2005). Voksne ordblinde - en antologi. Dansk Psykologisk Forlag.

Danmarks Evalueringsinstitut (2005). Forberedende voksenundervisning. København: Danmarks Evalueringsinstitut. (http://217.61.44.102/Admin/Public/ Download.aspx?file=Files/Filer/ Rapporter\%202004/Forberedende\% 20voksenundervisning/FVU-rapport.pdf) Danmarks Evalueringsinstitut (2006). Forberedende voksenundervisning. Årsrapport 2006. København: Danmarks Evalueringsinstitut.

Dansk Videnscenter for Ordblindhed (2006). Rapport om afprøvning af visita- tionstest til brug i ordblindeundervisning for voksne. København: Undervisningsministeriet.

(http://us.uvm.dk/voksen/fvu/documents/ endelig_rapport.doc)

Elbro, C., Møller, S. \& Nielsen, E. M. (1991). Danskernes lasefærdigheder. En undersøgelse af 18-67-åriges lessning af dagligdags tekster. København: Projekt Læsning og Undervisningsministeriet.

Engell, L. V. (2003). Derfor FVU på arbejdspladsen! København: Undervisningsministeriet. (http://us.uvm.dk/ voksen/fvu/fvu-cases/alle_artikler.pdf).

Gabrielsen, E., \& Myrberg, M. (2001). Adult education for at-risk groups. In: Tuijnman, A. \& Hellström, Z. (eds.). Curious Minds. Nordic Adult Education Compared (pp. 105-115). København: Nordisk Ministerråd.

Gellert, A. (1999). Hvordan kan man forudsige forskelle i elevers læseforståelse af faglige uddannelsestekster? En undersøgelse af en elevgruppe på den pædagogiske grunduddannelse. Psykologisk Pcedagogisk Rådgivning, 36(5-6), 395-418.

Grønborg, A. Madsen, P. Nielsen, B. \& Sørensen, H. (1994). Incidensundersøgelse. En undersøgelse af lcese- og stavestandpunktet blandt elever på teknisk Skole og AMU-skolen i Odense foretaget i foråret 1994. Odense: Fyns Amts Taleog Høreinstitut.

Handels-, Transport- og Serviceerhvervenes Arbejdsgiverforening \& Institut for Konjunktur-Analyse (2004). Det rummelige Arbejdsmarked. Tiltrceke, fastholde, udvikle. København: HandelsTransport- og Serviceerhvervenes Arbejdsgiverforening.

Harboe, A.H. (2005). Læse- og skrivekrav i erhvervsuddannelserne. Lœesepæedagogen 5, 20-23.

Harboe, A.H. (2004). Rapport om Læeseprojektet i ungdomsuddannelserne i skoleåret 2003-2004. Århus: Uddannelsesrådet i Århus Amt.

Haven, D. (1998). Gode og dårlige læsere efter 9. klasse. Anden del af en efterundersøgelse. Psykologisk Pædagogisk Rådgivning, 35(5/6), 454-472.

Holders, B., Petersen, D.K., Borstrøm, I. \& Elbro, C. (1996). Undervisning af voksne ordblinde. En undersøgelse af undervisningseffekt og lcererkvalifikationer i ordblindeundervisningen i AOF. København: Forlaget Skolepsykologi. 
Jensen, T.P. (2002). Literacy-kompetence. I: Uddannelsesstyrelsen: Nøglekompetencer - forskerbidrag til Det Nationale Kompetenceregnskab. København: Undervisningsministeriet. (http://pub.uvm. $\mathrm{dk} / 2002 / \mathrm{nkr} /$ dokumentationsrapport/)

Jensen, T. P. (2006). Lcese- og skrivesvages deltagelse i voksen- og efteruddannelse. København: AKF Forlaget. (http://www.akf.dk/udgivelser/2006/pdf/ laese_skrivesvages_veu.pdf)

Jensen, T. P., Andersen, A.R., Brown, R., \& Hansen, E.B. (2006). Lese-stavesvages brug af VEU. København: AKF Forlaget. (http://www.akf.dk/udgivelser/ 2006/pdf/laese_stave_svages_veu.pdf)

Jensen, T.P., Andersen, A. \& Halgreen, T. (2001). Lasefcerdigheder og deltagelse $i$ samfundslivet. København: Amternes og Kommunernes Forskningsinstitut \& Specialarbejderforbundet i Danmark (SID).

Jensen, T.P. \& Holm, A. (2000). Danskernes lcese-regne-fcerdigheder - $i$ et internationalt lys. København: AKF Forlaget.

Jensen, T.P. \& Holm, A. (2000). Læsekurser for voksne, udbytte og tilrettelceggelse. København: AKF Forlaget.

Jensen, V. B., Erdmann, O. \& Gravesen (1995). Svage læesere på HTX. København: Københavns Tekniske Gymnasium.

Kjær, S., Lind, H. \& Villadsen, S. (1999). Faglige teksters lasbarhed - en effektundersøgelse på Novo Nordisk. København: Københavns Universitet. (Bachelorprojekt).

Knudsen, L. (undervejs). Faglige tekstgenrer i 8. klasse. En effektundersøgelse af undervisning i generekendskab. København: Center for Læseforskning, Københavns Universitet.

Københavns Kommune (2005). Spids pennen - en evaluering af hotlinefunktionen. København: Undervisningsministeriet. (http://us.uvm.dk/voksen/fvu/ documents/hotlinefunktionen.pdf)

Larson, A. (2005). Psykosociale forhold $i$ arbejdslivet og kortuddannede/ufaglertes interesse for uddannelse. (Ph.d-afhandling). København: Danmarks Pædagogiske Universitet.

Lau, J., Holst, C., Brøcker, A. \& Klausen, A.B. (1995). Nytter det noget? - om den kompenserende specialundervisning for lase- og stavehandicappede i Arhus Amt. Århus: Århus Amt \& Danmarks Pædagogiske Institut.
Lau, J. \& Sommer, M. (1999). Voksne lceser på arbejdspladsen. København: Danmarks Pædagogiske Institut.

Lausch, B., Jakobsen, K. \& MunchHansen (1999). Jeg leeste en hel bog og nu tør jeg også skrive - faglig lasning og skrivning på erhvervsskoler. København: Undervisningsministeriet.

Lund, J. \& Pedersen, L. V. (2006). Effekt af FVU \& Anbefalinger til Uddannelsesaktører på FVU-området. København: Mercuri Urval.

(http://us.uvm.dk/voksen/fvu/documents/ kvu_rapport.pdf)

Lund, K., Bertelsen, E. \& Sørensen, M.S. (2006). Muligheder og barrierer - en undersøgelse af overgangen mellem sprogcentre og erhvervsrettede uddannelser. København: Ministeriet for Flygtninge, Indvandrere og Integration. (http://www.nyidanmark.dk/NR/rdonlyre s/01C5917D-4222-49C4-9BA28BEB58800ECA/0/Muligheder_barriere r.pdf)

Mejding, J. (2004). PISA 2003 - Danske unge $i$ en international sammenligning. København: Danmarks Pædagogiske Universitets Forlag.

Munch-Hansen, T. \& Albæk, K. (1994). Faglces - et analyse- og udviklingsprojekt om leesesvage i arbejdsmarkedsuddannelserne. København: Arbejdsmarkedsstyrelsen.

Møller, S. \& Elbro, C. (1992). Ufaglcertes lessning. En undersøgelse af ufaglerte arbejderes leesning set i relation til andre voksnes lasning. København: Specialarbejderforbundet i Danmark (SID).

Møller, S. \& Nielsen, R. (1986). Svage lasere eller dårlige tekster? En undersøgelse af tekster og lesere på kurser for specialarbejdere. Pædagogiske forskningsrapporter nr. 35. København: Læsepædagogen.

Nielsen, A. S. (1999). Læese- og stavetrcening for voksne i arbejde. København: Danmarks Pædagogiske Institut.

Nielsen, G.Ø., Johansen, J., Nielsen, J.C. \& Nissen, T. (1996). Laseundervisning af voksne indvandrere - et udviklingsarbejde. København: Danmarks Pædagogiske Institut.

Nielsen, I. \& Petersen, D. K. (1992). DIAVOK. En diagnostisk lcese- og stavetest. København: AOF-Danmark.

NIRAS-konsulenterne (2006). Evaluering af kompetenceudviklingsprojekt „Skriftlig kommunikation " for medarbejdere $i$ 
Greve Kommunes Hjemmepleje. Slutevaluering. Roskilde: Roskilde Amt. OECD (2000). Literacy in the Information Age: Final Report of the International Adult Literacy Survey. Paris: OECD. Pedersen, L.B.T. \& Løvengreen, K. (2006). Brancherettet FVU - et idékatalog om information og tilrettelceggelse af FVU på virksomheder. København: FVU-team Storkøbenhavn. (http://www.fvu-team.dk/pdf/opsoeger katalog_samlet.pdf)

Trepartsudvalget (2006). Livslang opkvalificering og uddannelse for alle på arbejdsmarkedet. Bind 1: Den fremtidige voksen- og efteruddannelsesindsats. København: Finansministeriet.

(http://www.fm.dk/1024/visPublikatione sForside.asp?artikelID=8112)

Undervisningsministeriet (2002). Undervisningsvejledning. Forberedende voksenundervisning (FVU) i lessning, stavning og skriftlig fremstilling. København: Undervisningsministeriet. (http://us.uvm.dk/voksen/fvu/undervisni ngsvejl_laesning.pdf)

Undervisningsministeriet (2004). Fakta om FVU. København: Undervisningsministeriet. (http://us.uvm.dk/voksen/ fvu/fvu-cases/fakta_om_fvu.htm? menuid $=350525$ )

Undervisningsministeriet (2004). Konferencerapport fra FVU-lcrerkonferencen 2004. Nye veje for voksne i arbejde. København: Undervisningsministeriet. (http://us.uvm.dk/voksen/fvu/informa tion_generel/konferencerapport fvu-ny.pdf)

\section{Danske webadresser}

Center for Laseforskning http://www.cphling.dk/laes/

Dansk Videnscenter for Ordblindhed http://www.dvo.dk/

Ministeriet for Flygtninge, Indvandrere og Integration http://www.nyidanmark.dk/da-DK/

SU-styrelsens portal om specialpcedagogisk støtte http://www.spsu.dk/

Undervisningsministeriet http://www.uvm.dk/
Undervisningsministeriet (2004). Vejledning til trinplacering (2. udgave). Afdcekning af FVU-deltageres erfaringer, fcerdigheder og strategier i lcesning, stavning og skriftlig fremstilling. København: Undervisningsministeriet. (http://us.uvm.dk/voksen/fvu/Vejledning er/documents/Trinplacering-laes-vejljuni04-vejl.pdf)

Undervisningsministeriet (2005). Det Nationale Kompetenceregnskab - Hovedrapport. København: Undervisningsministeriet.

(http://pub.uvm.dk/2005/NKRrapport/)

Undervisningsministeriet (2006). Fakta om forsøg med etablering af ord-og regnevcrksteder for deltagere i erhvervsrettet voksen- og efteruddannelse på erhvervsrettede uddannelsesinstitutioner. København: Undervisningsministeriet.

(http://us.uvm.dk/amu/fou/tup/document s/Ord-

ogregnevaerkstederforkortudd.udmeldingstekst_000.pdf)

Undervisningsministeriet (2006). Foreløbig vejledning om visitation til ordblindeundervisning for voksne. Indledende samtale, obligatorisk test og visitation. København: Undervisningsministeriet. (http://us.uvm.dk/voksen/fvu/documents/ visitationsvejledning.doc)

Viig, M. (2006). Info-centre for ordblinde. Status set i forhold til overførsel af midler fra 2005 til 2006. Haderslev: VUC Sønderjylland. 


\section{Norske referencer}

Bekkevold, K., Yin, H., Servan, K.T., Jørgensen P.M. \& Anderssen, A.F. (2005). Grundleggende ferdigheter i norsk arbeidsliv. Resultater fra Voxbarometeret høsten 2005. Oslo: Vox. Bratsberg, B., Hægeland, T. \& Raaum, O. (2006). Lese- og tallforståelse, utdanning og arbeidsmarkedssuksess. Stavanger: Universitetet i Stavanger, Lesesenteret.

Engesbak, H. \& Finbak, L. (2005). Mye vil ha mer - om deltakelse i etter- og videreutdanning. Samfunnsspeilet 3. (http://www.ssb.no/ssp/)

Engesbak, H., Haugerud, V., Røstad, S. \& Stubbe, T.A. (2003). Men hvor skal vi henvende oss? Oslo: Vox.

Engesbak, H. \& Stubbe, T.A. (2005). I videregående som voksen. Voksnes rett til grunnskole og videregående opplæring. Oslo: Vox.

Finbak L \& Engesbak, H. (2006). Å delta eller ikke delta. Om voksnes deltakelse i etter- og videreutdanning. Stavanger: Universitetet i Stavanger, Lesesenteret.

Gabrielsen, E. (2000). Slik leser voksne i Norge. En kartlegging av leseferdigheten i aldersgruppen 16-65 år. Stavanger: Universitetet i Stavanger, Lesesenteret.

Gabrielsen, E. (2002). Lese for livet. Lesekompetansen i den norske voksenbefolkningen sett i lys af visjonen om en enhetsskole. Bergen: Universitetet i Bergen, Institut for Samfunnspsykologi.

Gabrielsen, E. (2005). Hvor godt må vi kunne lese for å fungere i dagens samfunn? Samfunnsspeilet 2.

(http://www.ssb.no/ssp/)

Gabrielsen, E. (2005a). Kan leseferdigheter måles og sammenlignes? Samfunnsspeilet 2, 39-44.

Gabrielsen, E. (2005b). Hvor godt må vi kunne lese for å fungere i dagens samfunn? Samfunnsspeilet 2, 45-49.

Gabrielsen, E. (2005c). Er vi egentlig så dårlige til å regne? Samfunnsspeilet 3, 15-20.

Gabrielsen, E. (2006). Slik kan voksnes leseferdigheter måles. Om teorigrunnlaget for IALS og ALL. Monografiserien ALL nr. 6. Stavanger: Universitetet i Stavanger, Lesesenteret.

Gabrielsen, E. (2006). Opplysninger fra Norge. Stavanger: Senter for leseforsking. (Upubliceret rapport udarbejdet i forbindelse med nordisk forprojekt om voksne kortuddannedes læsning).

Gabrielsen, E., Haslund, J. \& Lagerstrøm, B.O. (2005). Lese- og mestringskompetanse i den norske voksenbefolkningen. Resultater fra „Adult Literacy and Life Skills“ (ALL). Stavanger: Universitetet i Stavanger, Lesesenteret.

Gabrielsen, E. og Lagerstrøm, B.O. (2005). Mange innvandrere er dårlige til å lese norsk. Samfunnsspeilet 2, 2-10.

Gabrielsen, E., \& Myrberg, M. (2001). Adult education for at-risk groups. In: Tuijnman, A. \& Hellström, Z. (eds.). Curious Minds. Nordic Adult Education Compared. (pp. 104-115). København: Nordisk Ministerråd.

Gabrielsen, E. og Ritland, A. (2000). Tre av ti leser for dårlig. Samfunnsspeilet 4, 36-43.

Hansen, G. (2003). Vellykket Voksenopplæring i Vestfold. Bris 2, 54-57. (http://www.nav.no/1073749975.cms) Haugerud, V., Røstad, S. \& Stubbe, T.A. (2005). Intensjoner og realiteter. Fylkeskommunenes håndtering av voksnes rett til videregående opplæring. Oslo: Vox.

Haugerud, V., Røstad, S. \& Stubbe, T.A. (2006). Grunnskoleopplæring for voksne. Oslo: Vox.

Hvenekilde, A., Alver, V., Bergander, E., Lahaug, V. \& Midttun, K. (1996). Alfa og Omega. Om alfabetiseringsundervisning for voksne fra språklige minoriteter. Oslo: Novus Forlag.

Høien, T. \& Tønnesen, G. (2004). Ordkjedetesten. Stavanger: Stiftelsen Dysleksiforsking.

Letrud, K.H. (2004). Fra sjenanse til verdighet. Å legge til rette for lese- og skriveutvikling i egen bedrift. Oslo: Vox. (http://www.vox.no/upload/Nedlastingss enter/sjenanseogverdighet.pdf )

Lundetræ, K. \& Gabrielsen, E. (2006). På lik linje? Om voksnes mestring av matematikk i dagliglivet. Stavanger: Universitetet i Stavanger, Lesesenteret.

Mørch, A. \& Solheim, I. (2005). Integrert e-læring i bedriften. Pedagogikk, teknologi, organisasjon. Oslo: Unipub Forlag.

Nyen, T. (2005). Livslang læring i norsk arbeidsliv II. Resultater fra Lærevilkårsmonitoren 2005. Oslo: Forskningsstiftelsen Fafo. 
Nyen, T. (2006). Hvis jobben krever det. En analyse av sammenhengene mellom krav til basisferdigheter, faktiske basisferdigheter og deltakelse i læringsaktiviteter i norsk arbeidsliv. Stavanger: Universitetet i Stavanger, Lesesenteret.

OECD (2000). Literacy in the Information Age: Final Report of the International Adult Literacy Survey. Paris: OECD.

Rikstrygdeverket, Senter for IKThjelpemidler \& Nonite (2005). Arbeidstakere og arbeidssøkere med lese/skrivevansker - 2002-2004. Projektrapport. Bodø: NAV NONITE - Nordnorsk IKT-senter.

Solheim, I. (2006). Strategi- og samarbeidslæring: utprøvning og spredning. Evaluering av samarbeidsprosjekt rettet mot læringsstrategier og leseforståelse i tilknytning til arbeidslivet. Oslo: Norsk Regnesentral.

Solheim, I. \& Ytrehus, S. (2005). Lese- og skriveopplæring som nytter. Etterundersøkelse av deltakere på AOFs lese- og

\section{Norske webadresser}

Lesesenteret ved Universitetet i Stavanger http://lesesenteret.uis.no/forskning/

Utdanningsdirektoratet

http://www.utdanningsdirektoratet.no/

VOX (Lering for Arbeidslivet)

http://www.vox.no/default.aspx?id=19

\section{Islandske referencer}

Arnardóttir, E. \& Kristmundsson, G.B. (2005). Um niðurstöður lestrarrannsóknar. [„,Om resultater fra læseforskning“]. Gátt - the annual review. Sími: Fræðslumiðstöð Atvinnulífsins.

Arnardóttir, E., Kristmundsson, G.B. \& Björnsdóttir, A. (2006). Læsi fullorðinna, lesiðni

og ritvenjur. [Literacy among adults, time used into reading and reading habits]. Reykjavík: Rannsóknarstofnun Kennaraháskóla Íslands.

Blöndal, P. (2006). Drög að náminu lögð á kaffistofunni. Starfstengt íslenskunám á vegum Albjóðahússins. [„,The study is organized in the coffee room. The Intercultural Centers language study in con- skrivekurs. Oslo: Forskningsstiftelsen Fafo.

Tønseth, C., Finbak, L., Rønning, W.M. \& Sølvberg, A.M. (2006). Digitale skillelinjer. Voksnes bruk av PC og Internett. Stavanger: Universitetet i Stavanger, Lesesenteret.

Utdannings- og forskningsdepartementet (2005). Læreplan i norsk og sammfunnskunnskap for voksne innvandrere. Oslo: Utdanningsdirektoratet. (http://www.utdanningsdirektoratet.no/u pload/larerplaner/norsk samfunnskunns kap_voksne_innvandrere.pdf)

Vox (2005). INOVI. Ikt i norskopplæringen for voksne innvandrere. Oslo: Vox.

Vox (2005). Sentrale begreber i norskplanen. In: Metodisk Vejledning. Læreplan i norsk og sammfunnskunnskap for voksne innvandrere. (pp. 26-31). Oslo: Vox.

Vox (2006). BASIS! Voksnes læring 2006 - tilstand, utfordringer og anbefalinger. Oslo: Vox nection to the jobs"]. Morgunblaðið, 24. september, 20-21.

Eggertsdóttir, R. og Jónsdóttir, P.B. (2001). Aðstoð við nemendur með leshömlun. Könnun í framhaldsskólum og háskólum veturinn 2000-2001. [,„Hjælp til ordblinde elever. Undersøgelse inden for videregående skole og universitet, 2000-2001“]. Akureyri: Universitetet i Akureyri.

Fræðslumiðstöð atvinnulífsins. [Arbejdslivets undervisningscenter]. (2004). Aftur í nám - námskrá. [Tilbage til uddannelse - studieplan]. Sími: Fræðslumiðstöð atvinnulífsins. 
Guðmundsdóttir, H. (2004). Annual report of grown ups informal education. Gátt. Sími: Fræðslumiðstöð Atvinnulífsins. Jónasdóttir, S. (2005). Námsáhugi fólks með litla formlega menntun.[,„Interesse for uddannelse hos voksne med kort formel uddannelse“]. Ritgerð til meistaraprófs við Kennaraháskóla Íslands. [MA-afhandling]. Reykjavík: Kennaraháskóli Î́slands.

Jónasson, J.T. \& Blöndal, K.S. (2002).

Progress and completion of students in upper secondary school in Iceland in light of their residence. A study of the cohort born in 1975. Reykjavík: University of Iceland, Social Science Institute.

Kolbeinsson, G. \& Ásbjörnsson, F. (1994). Lestu betur [„„Læs bedre“]. Reykjavík: IĐNÚ.

Lund, R. (2006). Innsamling av nasjonale opplysninger i Island i forbindelse med nordisk førprosjekt om kortutdannede voksnes lesning. Reykjavik: Lestrarsetur Rannveigar Lund.

Lund, R. og Lárusdóttir, A. (2004). GRP14 Handbók. Greinandi ritmálspróf fyrir 14. ára

emendur. Reykjavík, höfundar.

Óskarsdóttir, G. G. (2000). The Transfer from School to Work. Studies on the Relationship between School and Employment. Reykjavík: University of Iceland, Social Science Institute. University of Iceland Press.

Stefánsdóttir, H.B. (2006). Eins og fræ sem er sett í nýja mold. [As a seed which is sowed in a new earth]. Eins og fólk er flest. [„Like other people“]. The Intercultural Centre Magazine. Alpjóðahúsið ehf .3. nummer, sept.

\section{Islandske webadresser}

Alpýðusamband Íslands

http://www.asi.is/displayer.asp?cat_id=768

Alpjóðahúsið [the Intercultural Center]

http://www.ahus.is/ahus/english/news/?cat_id=23336\&ew_0_a_id=232091

Dóms- og kirkjumálaráðuneytið

http://www.reglugerd.is/interpro/dkm/WebGuard.nsf/key2/053-2003

Fræðslumiðstöð atvinnulífsins (AO)

www.frae.is

http://www.fraedslumidstod.is/default.asp?Id=432 link: Yfirlýsing ríkisstjórnarinnar 15. 11.05 PDF snið

http://www.frae.is/VI//Files/\%7B1d6d2424-fc12-45b0-a7a6bd795c8c2d33\%7D_landnemask\%C3\%B3linn\%20\%C3\%A1\%20ensku.doc http://www.frae.is//files/\{1b2b75a0-443e-4169-b11c319bf485f195\}_opnun\%20fa.pps

\section{Menntamálaráðuneytið}

http://nor.menntamalaraduneyti.is/love/nr/2485 (Sótt á vef 26.7.2006)

http://nor.menntamalaraduneyti.is/uddannelsessystemet/beskrivelse

http://bella.mrn.stjr.is/utgafuskra/leit-

nidurstodur.adp?leitarord=Aukin+lestrarf\%E6rni+fullor\%F0inna

http://brunnur.stjr.is/mrn/logogregl.nsf/FF6C260B2319251D002567BA004D88CB/5BF 79E6E5FA409ED00256E4300431F93?OpenDocument

http://www.mrn.stjr.is/log-og-reglugerdir/

http://bella.mrn.stjr.is/utgafuskra/rit.adp?id=34495 (PDF file)

http://bella.mrn.stjr.is/utgafuskra/leit-

nidurstodur.adp?leitarord=Aukin+lestrarf\%E6rni+fullor\%F0inna

http://nor.menntamalaraduneyti.is/uddannelsessystemet/beskrivelse

Mímir-Símenntun

http://www.mimir.is/asp1/listi_namskeid.asp?l=1\&f=12 
Námsflokkar Reykjavíkur

http://www.namsflokkar.is/

Starfsafl

http://www.starfsafl.is/starfsafl/en/

\section{Finske referencer}

Gunnilstam, O. \& Mårtens, M. (2002). Lexia 4 - Handbook. Sköndal: Stiftelsen Stora Sköndal.

Haapasalo, Lund \& Halonen (eds.). (2006). Luki-lukkoja avaamassa 20022005. LUKKI-hankkeen loppuraportti. [„,Opening dyslexia-locks 2002-2005. The final report of LUKKI-project"]. Turku: Turun kristillisen opiston säätiö. (http://www.tk-opisto.fi/liitteet/tko00010424-2.pdf)

Haapasalo, S. \& Salomäki, J. (2000). On kuin kivi olisi vierähtänyt sydämeltä. Kokemuksia aikuisten erilaisten oppijoiden ryhmäkuntoutuksesta. [„,It's like rolling a stone down from one's heart. Experiences from group rehabilitation of adult diverse learners"]. Helsinki: Kuntoutussäätiön tutkimuksia 64. Halonen, M. \& Peltoniemi, A. (2003). Äänteellistä ja kielellistä valmiutta kehittäviä harjoituksia. Maahanmuuttajien erityiset kielelliset oppimisvaikeudet. [,Assignments for practising phonetic and linguistic capacity. Specific lingual learning difficulties of immigrants"]. Turku: Turun kristillisen opiston säätiö.

Helén, E. (2001). Dyslexic adults' nonverbal visual-auditory and auditory-visual associative learning. Jyväskylä: University of Jyväskylä, Department of Psychology. (Unpublished Master's thesis).

HERO/Herosak (2003). SF-SOL. Södra Finlands Skriv- och Läsprojekt 20012002. Helsinki: HERO/Herosak.

Holopainen, L., Kairaluoma, L., Nevala, J., Ahonen, T., \& Aro, M. (2004). Lukivaikeuksien seulontamenetelmä nuorille ja aikuisille. [„,Dyslexia screening tool for youth and adults“]. Jyväskylä: University of Jyväskylä, Niilo Mäki Institute.

Hätinen, P. (2001). Lukivaikeus aikuisiällä. [,Dyslexia in adulthood“]. Joensuu: University of Joensuu, Department of Education. (Unpublished Master's thesis).
Hölkki, H. \& Salonen, L. (2006). Onko lukiossa lukivaikeutta? Opiskelijoiden kokemuksia lukemisen vaikeudesta. [„Is there dyslexia in upper general secondary school? Students experiences from difficulty in reading"]. Joensuu: University of Joensuu, Department of Special Education. (Master's thesis).

Jokinen, J.M. (1994). Aikuisopiskelijoiden luetun ymmärtäminen. [„,Reading comprehension of adult students“]. Jyväskylä: University of Jyväskylä, Department of Special Education. (Master's thesis).

Kakkuri, I. (1993). Aikuisten lukemis- ja kirjoittamisongelmat ammatillisessa aikuiskoulutuksessa, työvoimakoulutuksessa ja kansanopistossa. [„Adults’ reading and writing difficulties in vocational adult education, manpower education and folk high school"]. Jyväskylä: University of Jyväskylä, Department of Special Education.

Ketolainen, H. (2003). Elämänkumppanina lukivaikeus. Elämänkertahaastatteluihin perustuva kolmen lukivaikeuksisen aikuisen elämismaailmaa kuvaava tutkimus. [,Dyslexia as a partner in life. Biography based study of life of three dyslexic adults"]. Rovaniemi: University of Lapland, Faculty of Education. (Unpublished Master's thesis).

Kivi, T. (2004). LATU maahanmuuttajilleprojekti. Raportti 1.10.2000-31.12.2003. [,,Track for immigrants. Report 1.10.2000-31.12.2003“]. Lahti: Tiedonpuu ry.

Kokkila, H. (2003). Elinikäiseksi oppijaksi aikuisiällä? Vailla toisen asteen tutkintoa olevien 30-54 vuotiaiden osallistuminen aikuiskoulutukseen ja käsitykset koulutuksen tarpeesta. [,Becoming a lifelong learner in adult age? Participating to adult education among 30-54 year old people without a secondary level qualification"]. Joensuu: University of Joensuu, Department of Sociology. Korhonen, T (1995). The Persistence of Rapid Naming Problems in Children 
with Reading Disabilities: A Nine-Year Follow-up. Journal of Learning Disabilities, 28(4), 232-239.

Kujala, T, Karma, K. Ceponiene, R., Belitz, S., Turkkila, P., Tervaniemi, M. \& Näätänen, R. (2001). Plastic neural changes and reading improvement caused by audiovisual training in reading-impaired children. Proceedings of the National Academy of Science, vol. 98.

Kukkonen, P., Kurki, A. \& Soukka, A. (2003). Mikä ihmeen näyttö? Tietoa nuorten näytöistä opiskelijalle, työpaikkaohjaajalle sekä opettajalle. [,What is skills demonstration? Information on youth's skills demonstrations for students, work place supervisors and teachers"]. Oulainen: Oulaisten terveydenhuolto-oppilaitos. (http://db3.edu.fi/esr/ tiedostot/OUTH\%20opas.pdf)

Kuntaliitto. (2004). Kromosomeista kaksoiskonsonantteihin: Lukibussin matkakirja. [,From chromosomes to double consonants. Travelling log of dyslexiabus"]. Helsinki: Kuntaliitto.

Lahtinen, M., Lankinen T., Penttilä, A., \& Sulonen, A. (2004). Koulutuksen lainsäädäntö käytännössä. [„,Legislation of education in practise"]. Juva: Tietosanoma, WSOY.

Lavikainen, H. (2005). Itseraportoitujen koulunkäynti- ja oppimisvaikeuksien yleisyys ja yhteydet lapsuuden ja nuoren aikuisuuden elämäntilanteisiin ja koettuun terveyteen. ["Prevalence of selfreported school and learning difficulties and connections to lifesituations and experience of health in childhood and young adulthood“]. Jyväskylä: University of Jyväskylä, Department of health. (Unpublished Master's thesis).

Lehtola, R. \& Lehto, J. (2000). Assessing dyslexia in Finnish high-school students: a pilot study. European Journal of Special Needs Education, vol. 15(3), 255-263.

Leinonen, S. (2001). Heterogeneity in adult dyslexic readers: Relating processing skills to the speed and accuracy of oral text reading. Reading and Writing, vol. 14(3-4), 265-296.

Linnakylä, P. (1991). Quality of Vocational Literacy: how Finnish vocational school students learn from text. Scandinavian Journal of Educational Research, vol. 53(4), 253-268.
Linnakylä, P., Malin, A., Blomqvist, I. \& Julkunen, S. (2000). Lukutaito työssä ja arjessa: Aikuisten kansainvälinen lukutaitotutkimus Suomessa. [,Literacy in work and life: adults international literacy research in Finland“]. Jyväskylä: University of Jyväskylä, Koulutuksen tutkimuslaitos.

LukSitko 1/2005, 2/2005, 1/2006.

Lund, A. (2004). LUKKI-projekti. In: Hämäläinen Riitta, Riitta Salin ja Airi Valkama (eds.).

Kromosomeista kaksoiskonsonantteihin, lukibussin matkakirja [„,From chromosomes to doubleconsonants: the journey story of Lukibussi“"]. Helsinki: Suomen kuntaliitto.

Nevala, J., Kairaluoma, L., Ahonen, T., Aro, M., \& Holopainen, L. (2006). Lukemis- ja kirjoittamistaitojen yksilötestistö nuorille ja aikuisille. [,,Test package for individual assessment of reading and writing skills for youth and adults"]. Jyväskylä: University of Jyväskylä, Niilo Mäki Institute.

OECD (2000). Literacy in the Information Age: Final Report of the International Adult Literacy Survey. Paris: OECD.

Ojanen, E. (2006). Finnish data for the Nordic pre-project. Jyväskylä: University of Jyväskylä, Niilo Mäki Institute. (Upubliceret rapport udarbejdet i forbindelse med nordisk forprojekt om voksne kortuddannedes læsning).

Opetushallitus [National Board of Education]. (2006). Luku- ja kirjoitustaidottomien aikuisten maahanmuuttajien koulutus. Suositus opetussuunnitelmaksi.

[,Education of illiterate adult immigrants. Recommendation for curriculum"]. Helsinki: Opetushallitus.

Opetusministeriö [Ministry of Education]. (1992). Opetusministeriön työryhmien muistioita. Promemorior av undervisningsministeriets arbetsgrupper 41 . Aikuisten lukemis- ja kirjoittamisvaikeuksia selvittäneen työryhmän muistio. [,NNotation of appointed team of adult learning and writing difficulties“]. Helsinki: Opetusministeriö.

Opetusministeriö [Ministry of Education]. (1999). Opetusministeriön työryhmien muistioita. Promemorior av undervisningsministeriets arbetsgrupper 6. Lukityöryhmän muistio. [,Notation of appointed dyslexia team"]. Helsinki: Opetusministeriö. 
Pajukoski, S. \& Koskinen, S. (2003) Erilaiset oppijat näytöissä, osaraportti II. Opetus, ohjaus ja näytön toteutus ammatillisessa peruskoulutuksessa. [„Diverse learners in skills demonstrations, project report II. Teaching, instruction and organising skills demonstration in vocational secondary school"]. Helsinki: Helsingin seudun erilaiset oppijat ry (HERO).

(http://www.saunalahti.fi/mik4/nayttoprojekti/tiedostot/2.valiraportti.doc)

Pajukoski, S. \& Rinne, E. (2002). Erilaiset oppijat näytöissä, osaraportti I. Erilaisen oppijan tunnistaminen sekä tuki- ja ohjaustoimet ammatillisessa peruskoulutuksessa. [„Diverse learners in skills demonstrations, project report I. Recognising diverse learner and support and counselling methods in vocational secondary school"]. Helsinki: Helsingin seudun erilaiset oppijat ry (HERO).

(http://www.saunalahti.fi/mik4/nayttoprojekti/tiedostot/raportti 1.doc)

Pajukoski, S., Tuomi, A. \& Koskinen, S. (2004). NÄYTTÖ - mahdollisuus erilaiselle oppijalle. Opas ammatillisen peruskoulutuksen opettajalle, työpaikkaohjaajalle ja opiskelijalle. [„,Demonstration, a possibility for a diverse learner. Guidebook for teachers of vocational schools, supervisor in the work place and the students"]. Helsinki: Helsingin seudun erilaiset oppijat ry (HERO). (http://www.saunalahti.fi/mik4/nayttoprojekti/tiedostot/hero.pdf)

Pöyhönen, A. (1997). Lukemisvaikeus ammatillisessa koulutuksessa aikuisopiskelijan kokemuksena. [,Adult students experience of reading difficulty in vocational school“]. Turku: University of Turku, Department of Education. (Unpublished Master's thesis).

Savikuja, T. (2005). Aikalisä-projekti ja erilaisen oppimisen polut 2002-2004. [,Aikalisä project and paths of diverse learning 2002-2004"]. Helsinki: HERO. Suhonen, H. (1999). Ääneen lukeminen on kaikista pahin. Kokeellinen tapauskertomus lukivaikeuksisen aikuisen opetuksesta. [„Reading aloud is worst of all. Experimental case story on teaching of dyslexic adult"]. Jyväskylä: University of Jyväskylä, Department of Special Education. (Unpublished Master's thesis).

Tilaéus, T. (2005). Lukemisen ja kirjoittamisen vaikeudet toisen asteen ammatillisessa koulutuksessa. [„,Reading and writing difficulties in vocational secondary level school“]. Jyväskylä: University of Jyväskylä, Department of Special Education. (Unpublished Master's thesis).

\section{Finske webadresser}

Adult Education Centres

http://www.ktol.fi/web/dokumentti.1.1.72.html

Folk High Schools

http://www.kansanopistot.fi/gb/yhdistys_gb/skoy_frameGb.html

Finnish Diverse Learner's Association

http://www.erilaistenoppijoidenliitto.fi/

\section{HERO}

http://www.lukihero.fi/

Immigration issues visit

http://www.mol.fi/mol/se/04_migration/index.jsp (in Swedish)

Kuntoutussäätiö [Rehabilitation Foundation]

http://www.kuntoutussaatio.fi/svenska/index.html.html

Lukibussi

http://www.lukibussi.net/swe/index.html 


\author{
Lukineuvola \\ http://www.lukineuvola.fi/svenska/index_html \\ Luki-tuki-keskus, Turku Christian Institute \\ http://www.tk-opisto.fi/ \\ Matriculation Examination Board \\ http://www.ylioppilastutkinto.fi/se/index.html \\ National board of Education \\ http://www.oph.fi/english/ \\ Noste-project \\ http://www.noste-ohjelma.fi/sve/default.asp \\ The Finnish law \\ http://www.finlex.fi/sv/ \\ Vocational Adult Education Centres in Finland \\ http://www.aike.fi/index.php
}

\title{
Svenske referencer
}

Alm, J. (1996). The dyslexia project at the employability institute of Uppsala. Vtu, 7. Uppsala: Arbetsmarknadsstyrelsen. (http://www.tuffa.nu/rapporter\%5CVtu_ 1996_7.pdf)

Alm, J. (2004). Dyslexia: Relevance of Concepts, Validity of Measurements, and Cognitive Functions. Uppsala: Acta Universitatis Upsaliensis. (http://www.diva-portal. org/diva/getDocument?urn_nbn_se_uu_ diva-4123-1_fulltext.pdf)

Bengtsson, S., Levén, A. \& Gustafson, S. (2006). Studier och delaktighet: En analys av några studenter med funktionshinder vid Linköpings universitet. Rapport till Strategigruppen för lika villkor. Linköping: Linköpings universitet. (www.liu.se/likavillkor/)

Claesson, S. \& Dahlgren, H. (2002). Att studera i fängelse. Utvärdering av klientutbildning inom kriminalvården. Göteborg: Göteborgs universitet: Institutionen för pedagogik och didaktik (www.kvv.se)

Eriksen, A. H. (1999). Turbo på de ordblinde. Fagbladet, vol. 31, pp. 14-15.

Fermischek, V. \& Åhlund, G. (2004). Dyslexiprojektet. Hjälpmedel - Anpassning - Skräddarsydda lösningar. Stockholm: Arbetsmarknadsstyrelsen.

Föhrer, U. \& Magnusson, E. (2003). Läsa och skriva fast man inte kan. Kompense- rande hjälpmedel vid läs- och skrivsvårigheter. Lund: Studentlitteratur.

Gerrevall, P. \& Jenner, H. (2001). Kommunikativ pedagogik och särskilda ungdomshem. Stockholm: Statens institutionsstyrelse (SiS).

Gustavsson, A-L.E. (1997). Att läsa - ett behov, ett krav, en nödvändighet. En analys av den första internationellt jämförande studien av vuxnas förmåga att förstå och använda skriftlig information. International Adult Literacy Survey. Linköpings universitet: Institutionen för pedagogik och psykologi.

Gustavsson, A-L.E. (2002). Att hantera läskrav i arbetet. Om industriarbetare med läs- och skrivsvårigheter.

Linköpings Universitet: Department of Behavioural Sciences.

Gustavsson, A-L.E. (2005). Jag fixar det oftast. Hur industriarbetare hanterar läs- och skrivkrav i arbetet. Lund: Studentlitteratur.

Høien, T. \& Lundberg, I. (2001). Dyslexi: Från teori till praktik. Stockholm: Natur och Kultur.

Jacobson, C. (2001). LäsKedjor. Stockholm: Assessio (tidligere Psykologiförlaget).

Jensen, J., Lindgren, M., Andersson, K., Ingvar, D.H. \& Levander, S. (2000). Cognitive Intervention in Unemployed Individuals with Reading and Writing 
Disabilities. Applied Neuropsychology, 7(4), 223-236.

Johansson, M. (1999). MG-kedjor. Frösön: MG Läs- och Skrivkonsult AB.

Johansson, M. (2004). LS - Reviderad Klassdiagnoser i läsning och skrivning för högstadiet och

gymnasiet. Stockholm: Assessio (tidligere Psykologiförlaget).

Järpsten, B. (2002). DLS för skolår 7-9 och år 1 i gymnasiet. Stockholm: Assessio (tidligere

Psykologiförlaget).

Karlsson, A. (2003). Writing and texts in construction. A case study of the daily reading and writing practices of construction workers. Stockholm: Stockholms Universitet, Institutionen för nordiska språk. (http://www.nordiska.su.se/ skriftbruk/byggrapport.pdf)

Karlsson, A. (2003). The cab is his office. A study of the reading and writing, texts and literacy environments of a truck driver. Stockholm: Stockholms Universitet, Institutionen för nordiska språk. (http://www.nordiska.su.se/skriftbruk/tra nsportrapport.pdf)

Karlsson, A. (2004). How to build a house from reading a drawing - Professional and popular mediations of construction. Visual Communication 3 (3), 251-279.

Karlsson, A. (2005). Goods, services and the role of written discourse. In: Gunnarsson, B. (ed.). Communication in the Workplace. (pp. 91-104) Uppsala: Uppsala University.

Karlsson, A. (2005). Variation as text politics. Five store texts and their roles in the new work order. In: Berge, K.L. \& Maagerø, E. (eds.). Semiotics from the North. Nordic approaches to systemic functional linguistics (pp. 85-98). Oslo: Novus.

Karlsson, A. (2006). Reading to be independent, writing to be controlled? Roles and literacies offered to workers in modern organisations. Stockholm: Stockholms Universitet, Institutionen för nordiska språk. (http://www.nordiska.su.se/ skriftbruk/Karlsson_Reading_to_be Independent.doc)

Kennemyr, I. Ridderstad, P. \& Tyreus, S. (2002). Datorn - kompensatoriskt hjälpmedel och stöd vid inlärning för vuxna elever med läs- och skrivsvårigheter. Stockholm: Folkbildingsrådet. (http://www.resurs.folkbildning.net/ download/515/loftadalendatorn hjalpmede.pdf)

Lavås, I. (2006). Svenska data i förundersökning av kortutbildade med läs- och skrivsvårigheter. Härnösand: Mittuniversitetet. (Upubliceret rapport udarbejdet i forbindelse med nordisk forprojekt om voksne kortuddannedes læsning).

Lindell, C.G. (1998). Dyslexi i arbetslivet : ett informationsmaterial om vuxnas läsoch skrivsvårigheter. Stockholm: Arbetarskyddsnämnden.

Lindström, Y. (2001). Vad har motiverat vuxna personer med läs- och skrivsvårigheter att börja studera? Luleå: Luleå Tekniska Universitet.

Lundberg, I. \& Wolff, U. (2003). Duvan. Dyslexiscreening för ungdomar och vuxna. Stockholm: Assessio (tidligere Psykologiförlaget).

Lundgren, T. (2001). IT-satsningar på området läs- och skrivsvårigheter/dyslexi. Observatoriet för IT, lärande, kunskap och kompetens, Stockholm: ITKommissionen.

(http://www.itkommissionen.se/dynamas ter/file_archive/020124/7f479597f0c95c d6fcf17815d0397d92/42_2001\%20ITsatsningar\%20p\%E5\%20omr\%E5det $\%$ 20l\%E4s-\%20och\%20skrivsv\% E5righeter_dyslexi.pdf)

Lundgren, T. (2003). Vad alla bör veta om läs- och skrivsvårigheter. Stockholm: Förbundet Funktionshindrade med läsoch skrivsvårigheter.

Malmodin, H. (2002). Volvo satsar på lästräning - 100 tog ny chans att lära sig läsa. Dagens Nyheter (ekonomidelen), 28/9-2002.

Michailakis, D. (2002). Studie av en arbetsplatsanpassning med IT-baserade hjälpmedel för funktionshindrade personer. Uppsala: Institutet för arbetsmarknadspolitisk utvärdering (IFAU).

Myrberg, M. (2001). Att förebygga och möta läs- och skrivsvårigheter: En översikt av aktuell forskning om läs- och skrivsvårigheter. Stockholm: Skolverket. Myrberg, M.(2003). Att skapa konsensus om skolans insatser för att motverka läsoch skrivsvårigheter. Stockholm: Lärarhögskolan i Stockholm, Institutionen för Individ Omvärld och Lärande. (http://www.lhs.se/iol/publikationer)

Myrberg, M. (2001). Att öppna språkgränser - klyftor och broar i vuxna invandrares läs- och skrivutveckling - En studie baserad på International Adult Literacy 
Survey och forskning om invandrares läs- och skrivinlärning på sittandraspråk. Stockholm: Lärarhögskolan i Stockholm. (http://www.skolverket.se/ publikationer?id=1086)

Myrberg, M., Gustavsson, A-L.E. \& Ericsson, A. (2000). International Adult Literacy Survey: Invandrares läs-, skriv- och räkneförmåga. Linköpings Universitet, Läspedagogiska Institutet EMIR. (http://skolnet.skolverket.se/pdf/ials.pdf)

Nielsen, C. (2005). Mellan fakticitet och projekt. Läs- och skrivsvårigheter och strävan att övervinna dem. Göteborg: Uddevalla, Acta Universitatis Gothoburgensis, Högskolan Trollhättan, Institutionen för individ och samhälle.

OECD (2000). Literacy in the Information Age: Final Report of the International Adult Literacy Survey. Paris: OECD.

Ohlsson,L.I.M. (2000). Rapport angående Läs- och skriv/dyslexiundervisning/på kriminalvårdsanstalten i Malmö. Lund: Lunds Universitet, Pedagogiska institutionen.

Pousette, S., Berns, T. \& Wirstad, J. (1999). AMS - Stava Rätt. Stockholm: Arbetsmarknadsservice.

Roos, E.E. (2004). Räcker det att ta bort trösklarna eller kan man snubbla ändå? Om studiesituationen för studerande med funktionshinder under Kunskapslyftet. Malmö: Malmö högskola.

Roos, E.E. (2006). Aldrig för sent. Verksam pedagogik för vuxna med läs- och skrivsvårigheter. Växjö: Växjö Universitet, Institutionen för Pedagogik. (http://www.sit.se/download/PDF/Dysle $\underline{\text { xi/Aldrig_för_sent,_slutvers.pdf) }}$
Skolverket (1996). Grunden för fortsatt lärande - En internationell jämförande studie av vuxnas förmåga att förstå och använda tryckt och skriven information. Stockholm: Skolverket.

Taube, K. (2002). Läsinlärning och självförtroende: psykologiska teorier, empiriska undersökningar och pedagogiska konsekvenser. Stockholm: Prisma.

Tjernström, M. (2004). Vuxna dyslektikers informationsbeteende -En undersökning av hur sex personer med dyslexi hanterar informationsproblem. Borås: Biblioteks- och Informationsvetenskap /Bibliotekshögskolan. (www.hb.se/bhs/ slutversioner/2004/04-92.pdf)

Tord, S. (1984). Vore kul att kunna skriva - en rapport om läs- och skrivsvårigheter bland vuxna. Stockholm: Utbildningsradion.

Utbult, M. (2003). När orden står i vägen: om läs- och skrivsvårigheter för fackligt aktiva inom LO-förbunden. Stockholm: Landsorganisationen i Sverige.

Witting, M. (1996). Studenters arbete med att övervinna läs- och skrivsvårigheter: process- och resultatredovisning av ett projekt vid Linköpings universitet. Solna: Ekelund.

Witting, M. (1996). Vuxnas kamp för att erövra språket i skrift: om att övervinna läs- och skrivsvårigheter och få tillgång till det skrivna ordet. Solna: Ekelund.

Wolff, U. (2005). Characteristics and varieties of poor readers. Göteborg: Acta Universitatis Gothoburgensis.

Ödman, M. (1997). Även en vuxen kan ha svårt att läsa och skriva: en skrift om dyslexi. Stockholm: Johansson \& Skyttmo.

\section{Svenske webadresser}

Botkyrka_fhs.pdf

www.brunnsvik.se/lspc Brunnsviks folkhögskola www.dyslexicentrum.se Lidingö dyslexicentrum www.focusalfa.se www.folkbildning.se/page/9/folkhogskolor.htm Omdömen och behörigheter på folkhögskola www.folkhögskola.nu Adresser till folkhögskolor med kurser för dyslektiker www.frolunda.data, Dyslexitest www.hfs.se Härnösands folkhögskolas Dyslexicentrum www.irishadar.se Iris Hadar www.irishadar.se Utbildning för invandrare med funktionsnedsättning www.ki.se/dyslexi Svenska Dyslexiföreningen www.ki.se/dyslexi, Dyslektikers rättigheter www.lo.se, LO 
www.larcentra.se Lärcentra

www.lpc.ostersund.se, Läspedagogiskt centrum madison@mailbox.swipnet.se, Dyslexitest www.mglos.se, Dyslexitest www.psykologiforlaget.se, Dyslexitest www.rawd.info Dyslexicentrum, Ystad www.rels.bollnas.se ReLs, (Resurscentrum Läs och Skriv) Bollnäs www.resurs.folkbildning.net www.s-d-c.se Stockholms Dyslexi Centrum (SDC) www.studera.nu/hprovet/ Intygsgivare för anpassat högskoleprov Svenskundervisning för invandrare Svenskundervisning för invandrare www.umea.se/komvuxmimer KomVux Mimer www.volvo.com Volvo Köping www.ostersund.lpc.se Läspedagogiskt centrum

\section{Ikke-nordiske referencer}

Askov, E. N. (1993). Approaches to assessment in workplace literacy programs: meeting the needs of all clients. Journal of Reading, 36, 550-555.

Askov, E. N. (2000). Workplace literacy: Evaluation of three model programs. Adult Basic Education, 10(2), 100-108.

Askov, E. N. \& Gordon, E. E. (1999). The brave new world of workforce education. New Directions for Adult and Continuing Education, vol. 83, 59-68.

Barton, P. (2000). What jobs require: Literacy, Education, and Training 19402006. Policy Information Report. Princeton NY: Educational Testing Service.

Belfiore, M. E. (2004). Reading Work. Literacies in the New Workplace. Mahwah: New Jersey: Lawrence Erlbaum Associates.

Chang, K.L. (1983). An Investigation of the Curricular and Occupational Reading Demands of the Plumbing Trade. M.A. Thesis. University of Calgary.

Davis, R.D. (2006). Den begavede dyslektiker. København: Klim. (Oversættelse af: Davis, R.D. (1997). The gift of dyslexia. New York: Perigee Books).

Diekhoff, G. M. (1988). An appraisal of adult literacy programs. Journal of Reading, vol. 31(7), 624-630.

Hull, G. (1993). Critical literacy and beyond: Lessons learned for students and workers in a vocational program and on the job. Anthropology and Education Quarterly, vol. 24(4), 373-396.

Hull, G. (1997). Changing Work, Changing Workers. Critical perspectives on Language, Literacy, and Skills. New York: State University of New York.
Hull, G. (1998). The changing world of work. Journal of Adolescent Literacy, 42(1), 26-29.

Hull, G. (2000). Critical literacy at work Journal of Adolescent Literacy, 43(7), 648-652.

Hull, G., Jury, M., Ziv, O. \& Katz, M. (1996). Changing work, changing literacy: A study of skill requirements and development in a traditional and restructured workplace (Final Report). Berkeley, CA: National Center for Research in Vocational Education, Center for the Study of Writing and Literacy.

Mikulecky, L (1982). The relationship between school preparation and workplace actuality. Reading Research Quarterly, 17(3), 400-419.

Mikulecky, L. (1985). Literacy Task Analysis: Defining and Measuring Occupational Literacy Demands. Paper presented at the National Adult Educational Research Association. Chicago, IL.

Mikulecky, L. (2000). Developing and Teaching in Workplace Literacy Programs. Paper presented at the Annual Meeting of the International Reading Association. Indianapolis.

Mikulecky, L., Albers, P. \& Peers, M. (1994). Literacy Transfer: a Review of the Literature. Indiana University: National Center on Adult Literacy.

Mikulecky, L. \& Diehl, W. (1980). Job Literacy: A Study of Literacy Demands, Attitudes, and Strategies in a CrossSection of Occupations. Indiana University, Bloomington. 
Mikulecky, L. \& Drew, R. (1991). Basic literacy skills in the workplace. In: R. Barr (ed.): Handbook of Reading Research II. New York: Longman.

Mikulecky, L. \& Ehlinger, J. (1986). The Influence of Metacognitive Aspects of Literacy on Job Performance of Electronics Technicians. Journal of Reading Behaviour, vol. 28(1), 41-62.

Mikulecky, L. \& Lloyd, P. (1993). The impact of workplace literacy programs: a new model for evaluating the impact of workplace literacy programs. Indiana University: National Center on Adult Literacy. (http://ncal.literacy.upenn.edu/ cgi-in/search.pl?int_topic_id=23;int_ type_id=0;submit=Find\%20Materials;int _matches $=32$;int_current_page $=4$ )

Mikulecky, L. \& Lloyd, P. (1996). Evaluation of Workplace Literacy Programs: a Profile of Effective Instructional Practices. Philadelphia: National Center on Adult Literacy.

(http://ncal.literacy.upenn.edu/cgibin/search.pl?int_topic_id=23;int_type_i $\mathrm{d}=0$; submit $=$ Find $\% 20$ Materials;int_matc hes=32;int_current_page $=3$ )

Mikulecky, L., Lloyd, P., Horwitz, L., Masker, S. \& Siemantel, P. (1996). A review of recent workplace literacy programs and a projection of future challenges. Philadelphia: National Center on Adult Literacy. Philadelphia: National Center on Adult Literacy.

(http://ncal.literacy.upenn.edu/cgibin/search.pl?int_topic_id=23;int_type_i $\underline{\mathrm{d}=0 \text {; submit }=\text { Find } \% 20 \text { Materials;int_matc }}$ hes=32;int_current_page $=3$ )

Mikulecky, L. \& Winchester, D. (1983). Job Literacy and Job Performance among nurses at varying employment levels. Adult Education Quarterly, vol. 34 (1).

Norback, J.S. (1995). Job Literacy: A Framework for Categorizing Skills and Assessing Complexity. Princeton, New Jersey: Center for Skills Enchancement. Norback, J.S. (1998). Literacy Skills Analysis for Job Training. University of Pennsylvania: National Center on Adult Literacy.

Norback, J.S., Rosenfeld, M. \& Wilson, S.T. (1994). Job Literacy Analysis: a Practical Methodology for Use in Identifying Job-related Literacy Skills. Princeton, New Jersey: Center for Skills Enchancement.
OECD (1997). Reading skills for the knowledge society, further results from the International Adult Reading Survey. Paris: OECD.

OECD (2000). Literacy in the Information Age: Final Report of the International Adult Literacy Survey. Paris: OECD.

OECD (2001). Knowledge and skills for life. First results from PISA 2000. Paris: OECD.

OECD (2005). Promoting Adult Learning. Paris: OECD.

Perin, D. (1994). Carving a Path from Job Materials to a Workplace Basic Skills Curriculum. Adult Learning, 5(4), 15-17.

Perin, D. (1994). Relationships between Student Variables and Pre-Post Gain in a Workplace Literacy Program. New York: Center for Advanced Study in Education, The Graduate School and University Center of the City University of New York.

Perin, D. (1994). Workplace Literacy for Psychiatric Health Care Workers: Final Performance Report. New York: Center for Advanced Study in Education, The Graduate School and University Center of the City University of New York.

Perin, D. (1997). Workplace Literacy Assessment. Dyslexia, 3, 190-200.

Philippi, J.W. (1988). Matching literacy to job training: Some applications from military programs. Journal of Reading, 31(7), 658-666.

Philippi, J.W. (1991). Literacy at work. The workbook for program developers. New York: Simon \& Schuster Workplace Resources.

Philippi, J.W. (1998). Essential Skills for the Care Team. External Evaluation. Final Report. The Eddy/Northeast Health and Rockefeller College, University at Albany.

Rush, R.T., Moe, A.J. \& Storlie, R.L. (1986). Occupational Literacy Education. Newark, DE: International Reading Association.

Sheenan-Holt, J.K. \& Smith, C. (2000). Does basic skills education affect adults' literacy proficiencies and reading practices? Reading Research Quarterly, 35(2), 226-243.

Sticht, T. (1997). Assessing foundation skills for work. In: H.F. O’ Neil (ed.). Workforce readiness: Competencies and Assessment. (pp. 255-292). Mahwah, NJ: Lawrence Erlbaum Associates. 
Sticht, T.G. (2001). The International Adult Literacy Survey: How well does it represent the literacy abilities of adults? The Canadian Journal for the Study of Adult Education, 15, 19-36.

Swanson, H.L. (1999). Reading Research for Students with LD: A Meta-Analysis of Intervention Outcomes. Journal of Learning Disabilities, 32(6), 504-532. Taylor, M.C. (2000). Transfer of learning in workplace literacy programs. Adult Basic Education, 10(1), 3-2 